Geology of the Rockland and Arbon Quadrangles, Power County, Idaho

GEOLOGICAL SURVEY BULLETIN 1399 


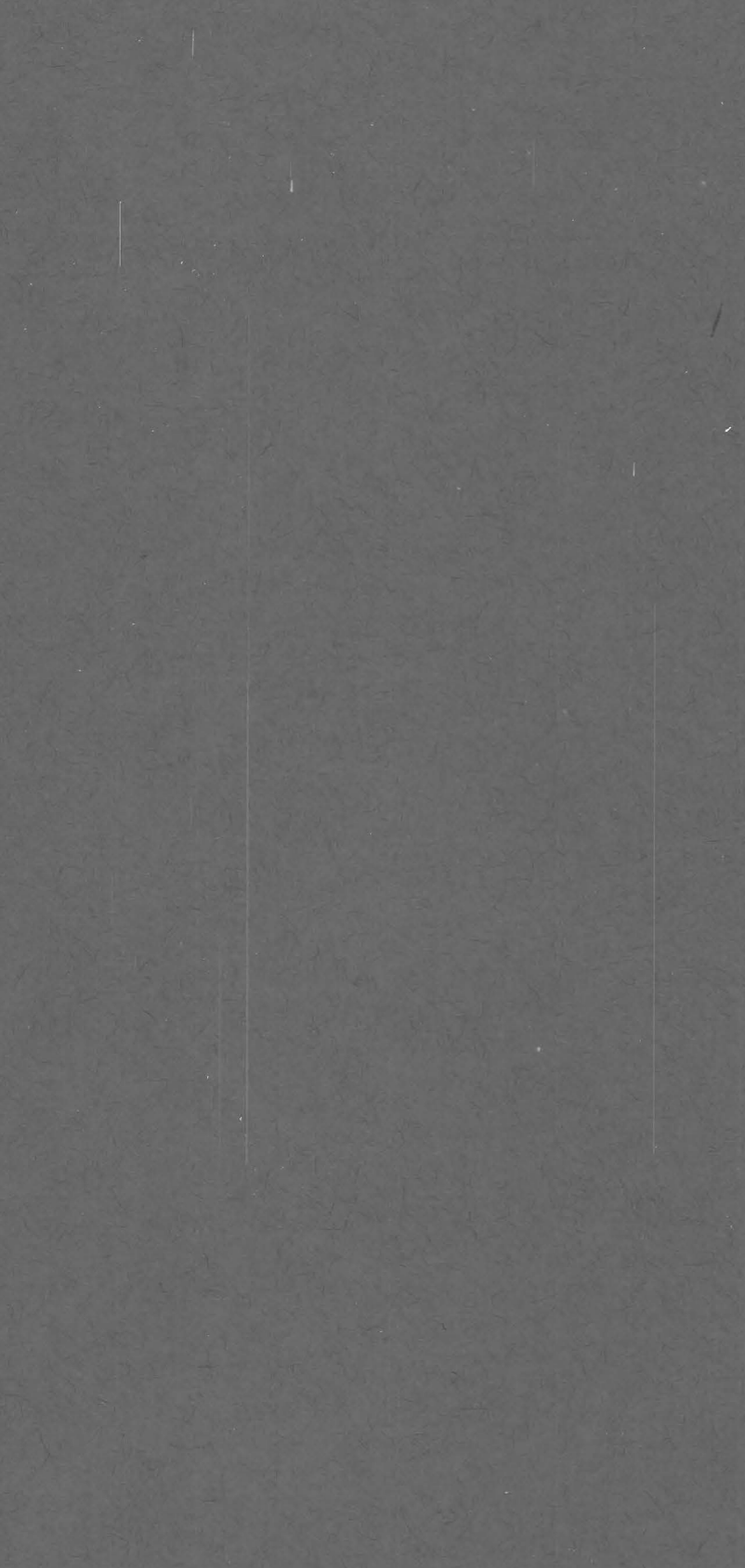




\section{Geology of the Rockland}

and Arbon Quadrangles, Power County, Idaho

By DONALD E. TRIMBLE and WILFRED J. CARR

GE OLOGICAL S U R VEY B U L LETIN 1399

Paleozoic and Tertiary stratigraphy and structure of an area at the southeast margin of the Snake River

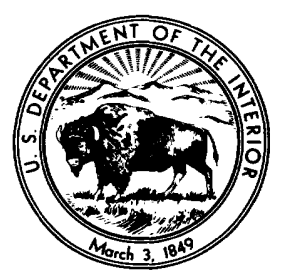




\section{UNITED STATES DEPARTMENT OF THE INTERIOR}

THOMAS S. KLEPPE, Secretary

\section{GEOLOGICAL SURVEY}

V. E. McKelvey, Director

Library of Congress Cataloging in Publication Data

Trimble, Donald E.

Geology of the Rockland and Arbon quadrangles, Power Country, Idaho.

(Geological Survey Bulletin 1399)

Bibliography: p.

Supt. of Doc. no.: I 19.3:1399

1. Geology-Idaho-Power Co.

I. Carr, Wilfred James, 1926- joint author. II. Title. III. Series: United States Geological Survey Bulletin 1399.

QE75.B9 no. 1399 [QE104.P65] 557.3'08s [557.96'49] 75-619323

For sale by the Superintendent of Documents, U.S. Government Printing Office Washington, D. C. 20402

Stock Number 024-001-02840-9 


\section{CONTENTS}

Page

System of measurement units. . . . . . . . . . . . . . . . . . . . .

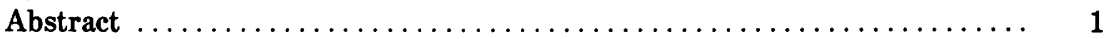

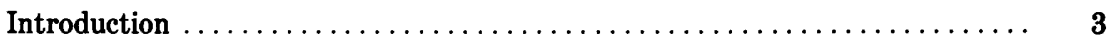

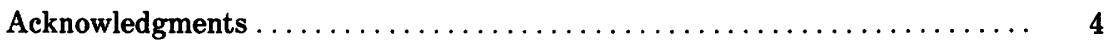

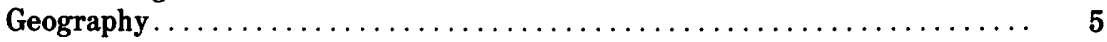

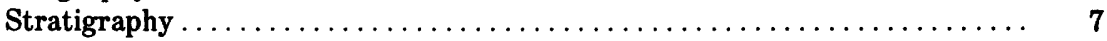

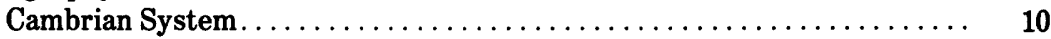

Camelback Mountain Quartzite (upper part) .............. 10

Gibson Jack Formation ....................... 11

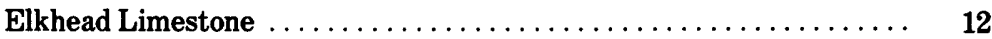

Bloomington Formation $\ldots \ldots \ldots \ldots \ldots \ldots \ldots \ldots \ldots \ldots \ldots \ldots, 13$

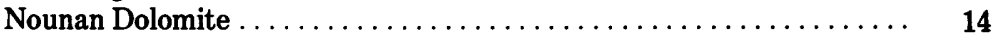

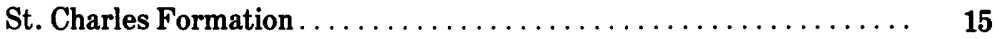

Worm Creek Quartzite Member $\ldots \ldots \ldots \ldots \ldots \ldots \ldots \ldots \ldots \ldots \ldots, 15$

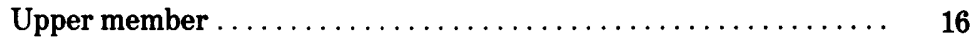

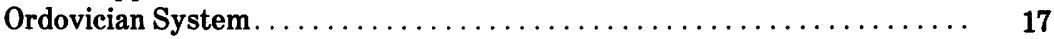

Garden City Formation $\ldots \ldots \ldots \ldots \ldots \ldots \ldots \ldots \ldots \ldots \ldots \ldots \ldots \ldots \ldots \ldots \ldots$

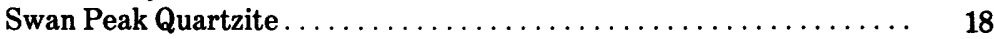

Fish Haven Dolomite . . . . . . . . . . . . . $\ldots \ldots \ldots \ldots \ldots . \ldots \ldots$

Silurian System . . . . . . . . . . . . . . . . . .

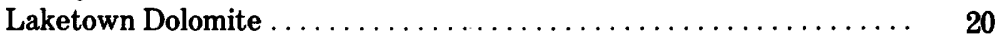

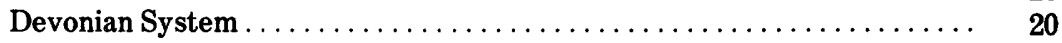

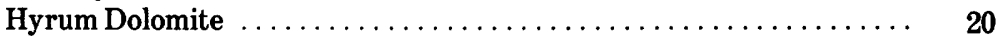

Beirdneau Formation $\ldots \ldots \ldots \ldots \ldots \ldots \ldots \ldots \ldots \ldots \ldots \ldots \ldots \ldots, 22$

Mississippian System $\ldots \ldots \ldots \ldots \ldots \ldots \ldots \ldots \ldots \ldots \ldots \ldots \ldots \ldots \ldots \ldots, \quad 22$

Lodgepole Limestone $\ldots \ldots \ldots \ldots \ldots \ldots \ldots \ldots \ldots \ldots \ldots \ldots \ldots \ldots, \quad 22$

Deep Creek Formation $\ldots \ldots \ldots \ldots \ldots \ldots \ldots \ldots \ldots \ldots \ldots \ldots \ldots, \mathbf{2 4}$

Great Blue Limestone $\ldots \ldots \ldots \ldots \ldots \ldots \ldots \ldots \ldots \ldots \ldots \ldots \ldots .25$

Mississippian and Pennsylvanian Systems $\ldots \ldots \ldots \ldots \ldots \ldots \ldots \ldots, 27$

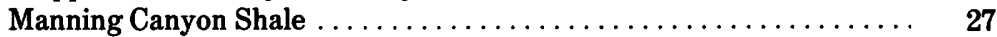

Pennsylvanian and Permian Systems . . . . . . . . . . . .

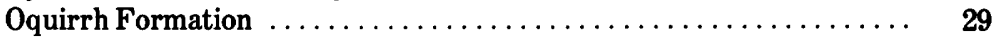

Tertiary System ................................... 33

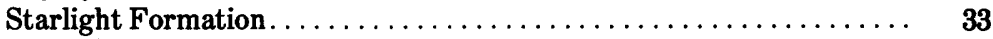

Lower member . . . . . . . .

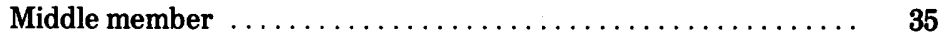

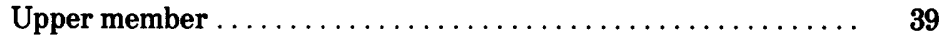

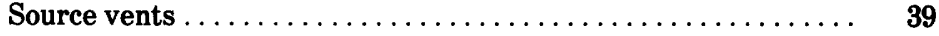

Intrusive rocks in the Starlight Formation $\ldots \ldots \ldots \ldots \ldots \ldots, \quad 40$

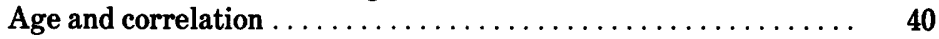

Gravel and conglomerate $\ldots \ldots \ldots \ldots \ldots \ldots \ldots \ldots \ldots \ldots$

Neeley Formation $\ldots \ldots \ldots \ldots \ldots \ldots \ldots \ldots \ldots \ldots \ldots \ldots \ldots, \mathbf{4 4}$

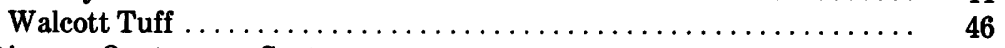

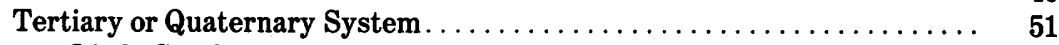

Little Creek Formation $\ldots \ldots \ldots \ldots \ldots \ldots \ldots \ldots \ldots \ldots \ldots \ldots, \mathbf{5 1}$

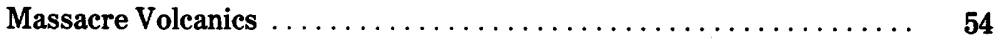


Stratigraphy-Continued

Quaternary System $\ldots \ldots \ldots \ldots \ldots \ldots \ldots \ldots \ldots \ldots \ldots \ldots \ldots \ldots \ldots$

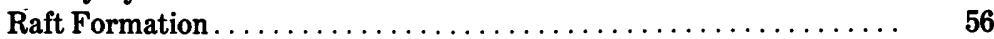

Pediment gravel................ 61

Big Hole Basalt . . . . . . . . . . . . . $62 \ldots \ldots \ldots \ldots \ldots \ldots \ldots$

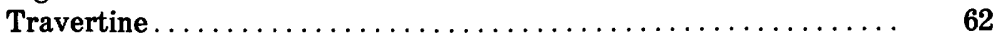

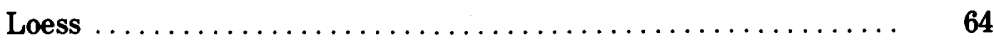

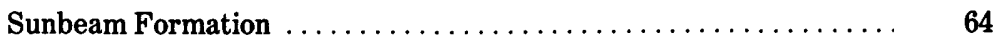

Cedar Bùtte Basalt. . . . . . . . . . . . . . . $65 \ldots \ldots \ldots \ldots . \ldots \ldots$

American Falls Lake Beds $\ldots \ldots \ldots \ldots \ldots \ldots \ldots \ldots \ldots \ldots \ldots \ldots, 66$

Aberdeen terrace deposits $\ldots \ldots \ldots \ldots \ldots \ldots \ldots \ldots \ldots \ldots \ldots, 68$

Boulder bars $\ldots \ldots \ldots \ldots \ldots \ldots \ldots \ldots \ldots \ldots \ldots \ldots \ldots \ldots \ldots \ldots \ldots$

Older alluvium $\ldots \ldots \ldots \ldots \ldots \ldots \ldots \ldots \ldots \ldots \ldots \ldots \ldots \ldots \ldots$

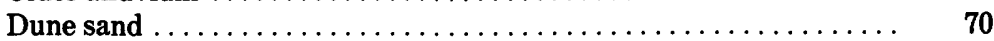

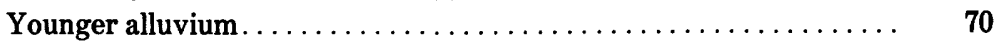

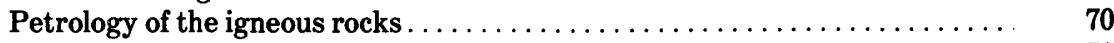

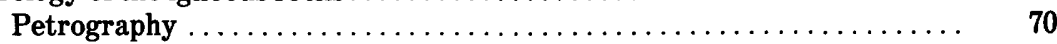

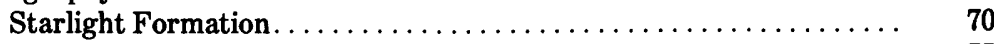

Neeley Formation $\ldots \ldots \ldots \ldots \ldots \ldots \ldots \ldots \ldots \ldots \ldots \ldots \ldots \ldots \ldots \ldots \ldots$

Walcott Tuff $\ldots \ldots \ldots \ldots \ldots \ldots \ldots \ldots \ldots \ldots \ldots \ldots \ldots \ldots \ldots, \quad 75$

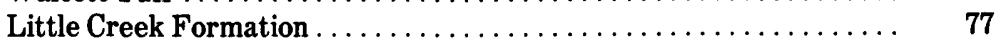

Massacre Volcanics ................................. 79

Big Hole Basalt $\ldots \ldots \ldots \ldots \ldots \ldots \ldots \ldots \ldots \ldots \ldots \ldots \ldots \ldots, \quad 80 \ldots \ldots$

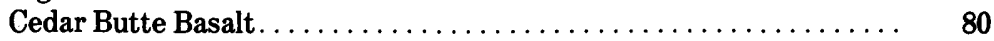

Composition of the basaltic rocks $\ldots \ldots \ldots \ldots \ldots \ldots \ldots \ldots \ldots \ldots \ldots, 81$

Composition of the silicic rocks $\ldots \ldots \ldots \ldots \ldots \ldots \ldots \ldots \ldots \ldots, 83$

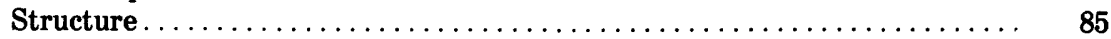

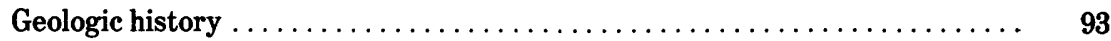

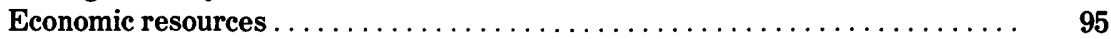

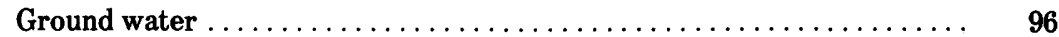

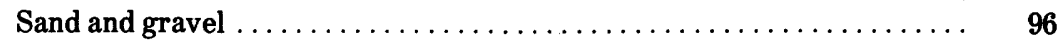

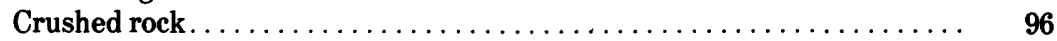

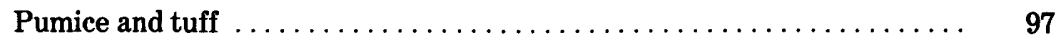

Diatomaceous clay ............................ 97

Metalliferous deposits . . . . . . . . . $\ldots \ldots \ldots \ldots \ldots \ldots \ldots \ldots \ldots$

Phosphate rock . . . . . . . . . . . . .

Measured sections of Paleozoic rocks $\ldots \ldots \ldots \ldots \ldots \ldots \ldots \ldots \ldots \ldots \ldots \ldots$

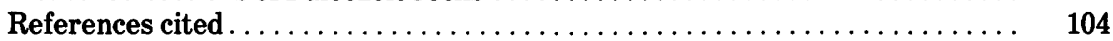

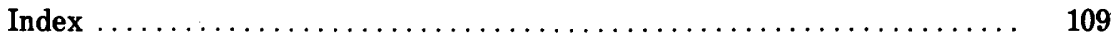

\section{ILLUSTRATIONS}

Plate 1. Geologic map and section of the Rockland and Arbon quadrangles, Idaho $\ldots \ldots \ldots \ldots \ldots \ldots \ldots \ldots \ldots \ldots$ In pocket

FIGURE 1. Index map of study area $\ldots \ldots \ldots \ldots \ldots \ldots \ldots \ldots \ldots \ldots$

2-8. Photographs showing:

2. Rockland Valley and the Deep Creek Mountains ....... 7

3. Bloomington Formation and Nounan Dolomite ........ 14

4. Swan Peak Quartzite and Fish Haven Dolomite ....... 18 
5. Hyrum Dolomite . . . . . . . . . . . . . . . . . . . 21

6. Middle shale member of the Great Blue Limestone .. . $\quad 26$

7. Faberophyllum in the Great Blue Limestone ....... 27

8. Oquirrh Formation.................... 31

9. Sections of the tuff of Arbon Valley from three localities.... . 37

10-12. Photographs showing:

10. Tertiary volcanic sequence $\ldots \ldots \ldots \ldots \ldots \ldots \ldots .47$

11. Neeley Formation and Walcott Tuff. ........... 48

12. Deformed bedding in the Walcott Tuff ......... 49

13. Diagrammatic sketch of the physical relations

between the Little Creek Formation and the various units of the Massacre Volcanics

14. Photograph showing the Raft Formation and the American Falls Lake Beds in bluffs of the Snake River . . . .

15. Map showing interpreted relationships of thrust faults in southeastern Idaho and northern Utah. . . . . . . . . . . .

16. Map showing structure contours on the tuff of Arbon

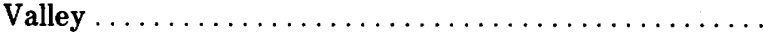

\section{TABLES}

TABLE 1. Formations of Paleozoic age exposed in the mapped

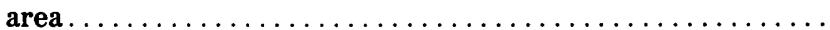

2. Distribution of fusulinid genera in the Oquirrh Formation of the Deep Creek Mountains ..............

3. Distribution of mollusks in the Starlight Formation in the Rockland and Arbon quadrangles ................

4. Mollusks from the American Falls Lake Beds, American Falls area .

5. Distribution of some heavy minerals in the rhyolitic Tertiary tuffs of the American Falls region

6. Average range of phenocryst composition of crystalrich upper part of the tuff of Arbon Valley

7. Chemical analyses of basaltic rocks of the American Falls area .

8. Spectrographic analyses for trace elements in basaltic rocks of the American Falls area

9. Composition of the silicic rocks of the Rockland-

Arbon area and other localities in southeastern Idaho.

\section{MEASURED SECTIONS}

SECTION G. Walcott Tuff, measured in lower Ferry Hollow, in the 
Section F. Little Creek Formation, measured in a steep ravine in the NW $1 / 4 \mathrm{SW}^{1 / 4} \mathrm{SW}^{1 / 4}$ sec. 28 , T. 8 S., R. 30 E., Rockland

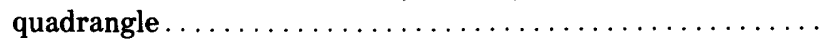

E. Little Creek Formation, measured in Ferry Hollow, in
the $\mathrm{SW}^{1 / 4} \mathrm{NE}^{1 / 4}$ sec. 6 , T. 8 S., R. 31 E., American Falls

E. Little Creek Formation, measured in Ferry Hollow, in
the $\mathrm{SW}^{1 / 4} \mathrm{NE}^{1 / 4}$ sec. 6 , T. 8 S., R. 31 E., American Falls quadrangle

D. Little Creek Formation, measured in the $\mathrm{SE}^{1 / 4} \mathrm{NW}^{1 / 4}$ sec. 13 , T. 9 S., R. 30 E., Rockland quadrangle ..............

C. American Falls Lake Beds and Raft Formation, measured
in the west bank of the Snake River opposite Neeley, in the $\mathrm{SE}^{1 / 4} \mathrm{SW}^{1 / 4}$ sec. 10, T. $8 \mathrm{~S}$., R. 30 E., Rockland quadrangle ..............................

B. Raft Formation, measured on the south bank of the Snake River in the SW $1 / 4$ sec. 23 , T. 9 S., R. 28 E., about 6.5 miles downstream from Massacre Rocks .............

A. Basalts of the Massacre Volcanics from Rockland Valley and from Eagle Rock, and part of the Little Creek Formation in a small gully in the $\mathrm{SW}^{1 / 4} \mathrm{SE}^{1 / 4}$ sec. 15 , T. 8 S., R. 30 E., Rockland quadrangle ...............

7. Begins above fault breccia at southwest tip of ridge above road into Buck Canyon, in the NW $1 / 4 \mathrm{NW}^{1 / 4}$ sec. $1, \mathrm{~T} .10 \mathrm{~S}$., R. $31 \mathrm{E}$., and ends at the top of hill, altitude about 7,750 feet, in the $\mathrm{NW}^{1 / 4} \mathrm{SE}^{1 / 4}$ sec. 31 , T. 9 S., R. 32 E., Rockland quadrangle . . . . . . . . . . . . . . . . . . . . . . .

6. Begins in saddle north of Water Canyon in the $\mathrm{NW}^{1 / 4} \mathrm{NE}^{1 / 4}$ sec. 26, T. 9 S., R. 31 E., and continues in secs. 23 and 24 to crest of divide, thence northward along divide in the $\mathrm{NW}^{1 / 4} \mathrm{SE}^{1 / 4}$ sec. 24, except for the Manning Canyon Shale, which was measured north of Well Canyon, beginning in saddle near center of sec. 23 , T. 9 S., R. 31 E., Rockland quadrangle

5. Type section of the Deep Creek Formation, begins about 100 feet northwest of bench mark 5,422 in the $\mathrm{N}^{1 / 2}$ sec. 35 , T. 9 S., R. 31 E., north side of Hunter Canyon, Rockland quadrangle.

4. About 6 miles north of Pauline, in the $\mathrm{SE}^{1 / 4}$ sec. 11 and the SW $1 / 4$ sec. 12 , T. 9 S., R. 33 E., Arbon quadrangle ........

3. About 2 miles north of Pauline, in the $\mathrm{SE}^{1 / 4}$ sec. 35, T. $9 \mathrm{~S}$., R. 33 E. . . . . . . . . . . . . . . . . . . . . . . . .

2. Begins at toe of spur on boundary between secs. 8 and 17, T. 8 S., R. 34 E., on Midnight Creek, Arbon quadrangle .....

1. NW $1 / 4 \mathrm{NE}^{1 / 4}$ sec. 7, T. 8 S., R. 34 E., northeast corner of Arbo

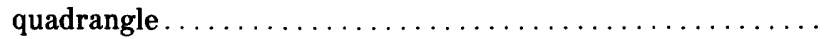




\section{SYSTEM OF MEASUREMENT UNITS}

The following report uses English units of measure throughout. These English units can be converted to metric units by multiplying by the following factors.

\begin{tabular}{|c|c|}
\hline $\begin{array}{l}\text { English unit } \\
\text { To Convert }\end{array}$ & Multiply by \\
\hline Feet...... & 0.3048 \\
\hline Inches & $\begin{array}{c}25.4 \\
2.54\end{array}$ \\
\hline Mil & 1.609 \\
\hline Square miles. . & 2.59 \\
\hline
\end{tabular}

\section{Metric unit}

To obtain

Metres (m).

Millimetres (mm).

Centimetres $(\mathrm{cm})$

Kilometres (km).

Square kilometres $\left(\mathrm{km}^{2}\right)$. 



\title{
GEOLOGY OF THE ROCKLAND AND ARBON QUADRANGLES, POWER COUNTY, IDAHO
}

\author{
By DONALD E. TRIMBLE and WILFRED J. CARR
}

\begin{abstract}
The Rockland and Arbon 15-minute quadrangles are in Power County, Idaho, southwest of Pocatello and south of American Falls. About half of the Arbon quadrangle is within the Fort Hall Indian Reservation.

The structural boundary between the Snake River Plain, a section of the Columbia Plateaus physiographic province, and the Basin and Range physiographic province diagonally crosses the northwestern part of the Rockland quadrangle. The area contains parts of the Sublett Range, the Deep Creek Mountains, and the Bannock Range. It is drained by the Snake River, which flows across the northwestern part of the Rockland quadrangle.

The rocks of this area include about 27,000 feet of Paleozoic sedimentary rocks, a sequence of volcanic rocks of mainly Pliocene age, and Quaternary fluvial, lacustrine, and eolian deposits.

The thick sequence of miogeosynclinal Paleozoic rocks is one of the most nearly complete in this region. The Cambrian rocks, about 11,000 feet thick, in general are lithologically similar to and correlative with the well-known Cambrian section of northern Utah and southeastern Idaho. Three names-the Camelback Mountain Quartzite (upper part), the Gibson Jack Formation, and the Elkhead Limestone (new)-are applied to the rocks of the lower part of the Cambrian section, but existing terminology is used for the other Middle and Upper Cambrian rocks, ineluding the Bloomington Formation, the Nounan Dolomite, and the St. Charles Formation.

The Ordovician, Silurian, and Devonian rocks are quartzite, limestone, and dolomite lithologically similar to equivalent rocks widespread in northern Utah and southeastern Idaho. The Ordovician rocks comprise the well-known trio of formations, the Garden City Formation, the Swan Peak Quartzite, and the Fish Haven Dolomite. The Silurian rocks consist of one formation, the Laketown Dolomite. The Devonian rocks are assigned to the Hyrum Dolomite and the Beirdneau Formation. Each of the Ordovician and Silurian formations and the total Devonian section is $1,000 \pm 150$ feet in thickness.

The lowest unit of Mississippian age is the Lodgepole Limestone, which is $\mathbf{3 7 0}$ feet thick. Above the Lodgepole is the Deep Creek Formation, which is more than 2,000 feet thick. The Paleozoic rocks above the Deep Creek Formation correspond in lithology and in age to the upper part of the Paleozoic sequence of the Oquirrh Range in Utah. The Mississippian Great Blue Limestone, the Mississippian and Pennsylvanian Manning Canyon Shale, and the Pennsylvanian and Permian Oquirrh Formation are recognized in the area of this report; they total nearly 9,500 feet in measured thickness.
\end{abstract}


Volcanic rocks of Tertiary and early Quaternary age partly fill the intermontane valleys and lap onto the lower flanks of the mountains. The oldest volcanic rocks are of middle Pliocene age and consist of the dominantly rhyolitic Starlight Formation, the Neeley Formation, and the Walcott Tuff. The Starlight Formation, which may be 1,000 feet or more thick, is mostly bedded rhyolitic tuff.

The Neeley Formation consists of nearly massive clayey sandstone and rhyolitic tuff as much as 100 feet thick. It overlies the Starlight Formation with apparent conformity.

The Walcott Tuff consists of a lower parallel-bedded tuff member, 7-12 feet thick, and an upper ash-flow welded tuff member, and conformably overlies the Neeley. The ash-flow tuff of the Walcott Tuff is very widespread, is generally about 15 feet thick but locally is more than $\mathbf{5 0}$ feet thick and may be continuous with the obsidian tuff near Ammon.

The Walcott Tuff and the Neeley Formation are extensive along the margin of the Snake River Plain, but they pinch out southward in Rockland Valley only a little more than 5 miles southeast of the Snake River.

Overlying the Walcott Tuff is the Little Creek Formation, 5-75 feet thick, which is redefined to exclude a basalt that is here reassigned to the Massacre Volcanics. The Little Creek consists of tuff and breccia characterized by interbedded and locally intermixed rhyolitic and basaltic material. The Little Creek is conformable with, but is separated from, the Walcott in most places by a layer of colluvium a few feet thick. It may be either late Pliocene or early Pleistocene in age.

The Little Creek is overlain with conspicuous unconformity by the basaltic rocks of the redefined Massacre Volcanics which consist of basaltic breccias, tuffs, and flows that were erupted from at least three centers. The age of the Massacre Volcanics is thought to be either late Pliocene or early Pleistocene.

The Raft Formation, locally more than 200 feet thick, is the oldest formation definitely known to be Pleistocene. It consists of light-colored beds of massive silt and clay, stratified silt, and sand.

At the foot of the mountains, pediment gravel mantles a surface that may have been cut to the same base level that controlled deposition of the Raft Formation.

The Raft Formation is overlain north of the Snake River by basalt flows referred to the Big Hole Basalt. This basalt is extensively mantled by loess which also covers the pediment gravel and older deposits south of the Snake River.

A valley cut into the Raft Formation was filled in late Pleistocene time with basalt from an eruptive center about 2 miles west of the Rockland quadrangle. This basalt - the Cedar Butte Basalt-dammed the ancestral Snake River to form a lake in which the bedded silt and clay of the American Falls Lake Beds were deposited.

Boulder bars along the Snake River in the Rockland quadrangle probably are a product of breaching of the basalt dam by a catastrophic spillover of pluvial Lake Bonneville.

Sand dunes cover much of the northwest corner of the Rockland quadrangle, north of the Snake River.

The igneous intrusive rocks of the area include vitrophyre plugs and porphyry dikes. A silicic porphyry dike intruding the Starlight Formation in the northern part of the Arbon quadrangle contains basaltic contaminants probably resulting from the mixing of magmas during emplacement.

The basaltic rocks of the area form two chemically dissimilar groups. The basalts of the Starlight Formation are higher in silica, alumina, and soda content and lower in magnesia than the younger basalts. They are chemically similar to the basalt type called "central" basalts. All the younger basalts are chemically similar to each other and to basalts in other parts of the Snake River Plain.

The silicic rocks are calc-alkali rhyolitic rocks with minor chemical differences. 
The structural boundary between the Basin and Range province and the Snake River Plain passes through the northwestern part of the Rockland quadrangle. The mountain blocks of the area are composed of Paleozoic rocks that have been folded and broken by both normal and thrust faults.

The Oquirrh Formation forms most of the. Deep Creek Mountains. These rocks were folded into a synclinorium and broken by north-trending faults in Jurassic or Cretaceous time. Gravity sliding of older Paleozoic rocks onto the Oquirrh Formation probably occurred at the same time.

The Paleozoic rocks older than Pennsylvanian are mostly within a large thrust plate that extends well beyond the borders of the area.

The present Basin and Range blocks are bounded by normal faults of large displacement formed in mid-Tertiary time. These blocks are truncated on the north by a concealed northeast-trending normal fault that forms a structural margin for the Snake River Plain, which is interpreted as a graben.

Sand and gravel, crushed rock, and ground water are Earth materials of present economic importance in this area.

\section{INTRODUCTION}

The Rockland and Arbon 15-minute quadrangles are in Power County, Idaho, southwest of Pocatello and south of American Falls (fig. 1). Interstate Highway $15 \mathrm{~W}$, which here follows the south side of the Snake River, crosses the northwest corner of the Rockland quadrangle. About half the Arbon quadrangle is within the Fort Hall Indian Reservation.

A thick section of Paleozoic rocks is exposed in the mountainous parts of the area. Tertiary tuffs, ash-flow tuffs, and basalt flows partly fill the intermontane valleys and lap onto the lower flanks of the mountains.

Only a very general subdivision of the Paleozoic rocks was attempted by Mansfield (1920) in his reconnaissance studies in the Fort Hall Indian Reservation in 1913, or later by Piper (1924). The upper Tertiary and Quaternary rocks along the Snake River were given more detailed attention by Stearns, Crandall, and Steward (1938), and later by Stearns and Isotoff (1956).

The present studies, begun in 1957 , were carried on jointly by the authors. About 18 man-months were spent in field mapping these two quadrangles. A report on the geology of the American Falls quadrangle (Carr and Trimble, 1963), directly north of the Rockland quadrangle, was completed in 1958 as part of this investigation.

An unusually complete sequence of upper Tertiary and Quaternary deposits occurs in the northern part of the study area, and in the American Falls quadrangle to the north (Carr and Trimble, 1963). Because these rocks provide the unique opportunity for understanding geologic events along the south margin of the Snake River Plain during this time, they received more attention than might ordinarily be given them. Also, particular attention was 


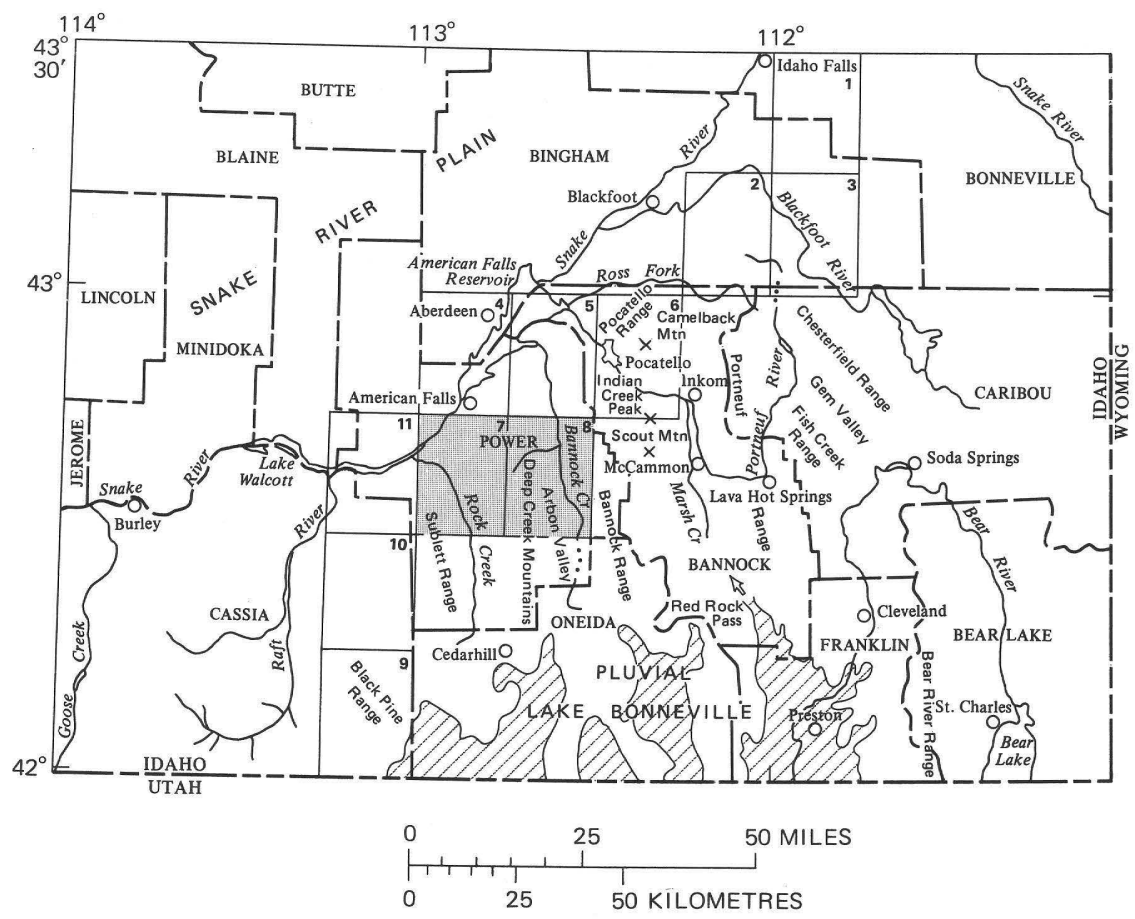

FIGURE 1.-Index map of southeastern Idaho, showing location of the area of this report (patterned) and other quadrangle study areas mapped or being mapped by the U.S. Geological Survey. Quadrangles are designated by number: 1, Ammon; 2, Yandell Springs; 3, Paradise Valley; 4, American Falls; 5, Michaud; 6, Pocatello; 7, Rockland; 8, Arbon; 9, Strevell; 10, Sublett; 11, Yale.

given to mapping the complex structure of the Paleozoic rocks, which resulted in a new interpretation of the thrust fault relations in this part of Idaho. Paleozoic rocks were subdivided in more detail than in previous work in the area, which has made possible more precise correlations with rocks in nearby areas; some of these results have been published separately (Carr and Trimble, 1961).

\section{ACKNOWLEDGMENTS}

Howard A. Powers, as general supervisor of the project, gave much valuable guidance, particularly in the study of the volcanic rocks.

Many paleontologists helped in the stratigraphic study by determining ages of the rocks. W. J. Sando and J. T. Dutro, Jr., visited the project for 1 week during the summer of 1958, examined parts of the Carboniferous section with us in the field, and made helpful suggestions about the age of some of the rocks which were later supplemented by detailed reports. R. J. Ross briefly 
examined the Orodovician rocks in 1958 and reported on several collections of fossils of that age.

Fusilinid determinations were made by R. C. Douglass, who examined the Pennsylvanian-Permian rocks in the Buck Canyon section in May 1961.

Tertiary and Quaternary molluscan faunas were examined in the field and subsequently identified by D. W. Taylor, who visited the area in 1957 and again in 1959. Several vertebrate collections were studied by G. E. Lewis.

Other specialists who reported on fossils from this area are A. R. Palmer, who studied the fossils of Cambrian age; E. L. Yochelson, who identified Permian gastropods; W. A. Oliver, Jr., who identified Ordovician corals; I. G. Sohn, who examined an ostracod collection; and Estella B. Leopold and Anne Davis, who studied the pollen in peat from the American Falls Lake Beds.

Meyer Rubin determined radiocarbon dates of samples from three localities which relate to the problem of Lake Bonneville chronology. Many chemists and spectroscopists who analyzed rock samples from the area are acknowledged specifically where the analyses are given.

Other assistance was given by T. C. Nichols, who brought a truckmounted power auger to the area and spent 10 days in 1959 in exploratory augering. Most of the subsurface studies, however, were in the American Falls and Michaud quadrangles to the north of the Rockland-Arbon area. Nichols and Jean Roach also made some of the laboratory mineral separations and mechanical analyses of unconsolidated sediments.

The studies were also aided by discussions with Walter Sadlick, Andrei Isotoff, and Marie L. Hopkins of Idaho State College. Sadlick gave helpful suggestions concerning the Carboniferous rocks, and Isotoff and Hopkins gave information concerning the Quaternary deposits.

Special mention is also made of the contribution of R. C. Bright of the University of Minnesota, who made available his unpublished descriptions of the rocks in the Cleveland area, Idaho.

\section{GEOGRAPHY}

The boundary between the Snake River Plain, a section of the Columbia Plateaus physiographic province, and the Basin and Range physiographic province diagonally crosses the northwestern part of the Rockland quadrangle, and the Snake River flows across the northwestern part of the quadrangle (fig. 1). The Arbon and Rockland quadrangles contain parts of three north-trending mountain ranges-the Sublett Range on the west, the Deep Creek Mountains, and the Bannock Range on the east. Rockland Valley lies between the Sublett Range and the Deep Creek Mountains and is 
drained by Rock Creek. Arbon Valley lies between the Deep Creek Mountains and the Bannock Range and is drained by Bannock Creek. Hilly areas occur within both Rockland and Arbon Valleys.

The crest of the Deep Creek Mountains within the quadrangles is mostly between 7,200 and 7,800 feet in altitude, except for Bannock Peak, which is 8,256 feet above mean sea level. The lowest point in the area, about 4,200 feet in altitude, is on the Snake River at the west edge of the Rockland quadrangle.

The climate and vegetation vary considerably between the valleys and mountains. The valleys are semiarid and are extensively dry-farmed. American Falls receives about 13 inches of precipitation a year. The higher altitudes receive enough moisture to support a pine and hemlock forest, especially on the north- and northeast-facing slopes. Deerbrush, aspen, and mountain mahogany also grow at the higher altitudes. On the north-facing slopes, nearly impenetrable thickets of brush are common.

Because the economy of the area is agricultural, the region is sparsely populated. The only town is Rockland (population 258, 1960 census) in Rockland Valley. American Falls (population 2,602), however, is only 2 miles north of the Rockland quadrangle, and Pocatello (population 42,500) is less than 10 miles northeast of the northeast corner of the area.

Both Rockland and Arbon Valleys are served by good, hard-surfaced highways, which connect with U.S. Highway $30 \mathrm{~N}$ (Interstate Highway 15W). There is also a network of unsurfaced secondary roads in the valley sections. The mountainous areas are accessible only by unimproved sheepherders' roads and trails.

A thick blanket of loess covers much of the area. In the valleys, outcrops of bedrock are small and scattered, and no float of the bedrock occurs between outcrops (fig. 2). Except in canyons, outcrops are seldom found on north-facing slopes. The north slopes retain enough moisture to encourage a slightly heavier cover of vegetation, which in turn results in less stripping away of the loess by erosion. In the higher mountains the loess is much thinner, and bedrock is fairly well exposed. Such conditions made mapping difficult and have raised several cartographic problems. In the valleys, only areas of actual bedrock have been mapped in most places. In the mountains, the area has been shown as solid outcrop, although it should be emphasized that many areas of thin cover exist. In a few areas, such as the northwest corner of the Arbon quadrangle and northeast corner of the Rockland quadrangle, distribution of Tertiary rocks beneath the surficial material is shown. In such places symbols for both units are shown on plate 1 to indicate, for example, loess over basalt. 


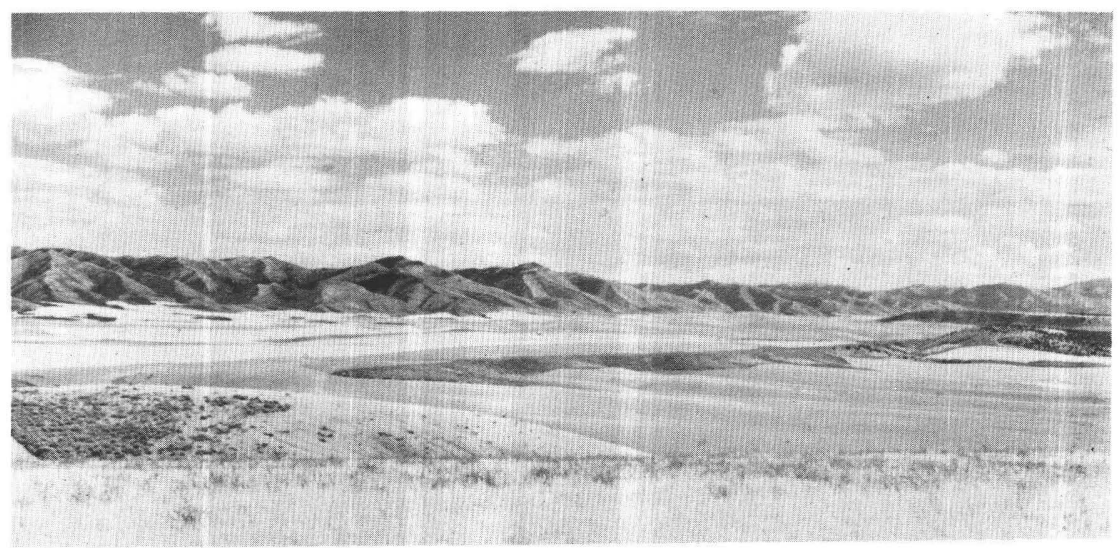

FIGURE 2.-Rockland Valley and the west front of the Deep Creek Mountains. The Hunter Canyon, Water Canyon, and Buck Canyon measured sections (measured sections 5, 6, and 7, respectively) are in the part of the range shown. Pervasive mantle of loess nearly completely conceals Tertiary and Quaternary rocks in the valley.

\section{STRATIGRAPHY}

All the systems of the Paleozoic are represented in a thick section of marine sedimentary rocks that compose the mountainous parts of the area (table 1). More than 13,000 feet of rocks older than Mississippian form the lower part of this sequence, and about 12,000 feet of rocks of Mississippian, Pennsylvanian, and Permian age form the upper part. Volcanic rocks, chiefly of Pliocene age, cover the intermontane valleys, and Pliocene and Pleistocene volcanic rocks cover the Snake River Plain. Quaternary deposits of fluvial, lacustrine, and eolian origin are present mainly on and bordering the Snake River Plain.

Pre-Mississippian rocks are like those that are widespread in southeastern Idaho and northern Utah. The rocks of Mississippian, Pennsylvanian, and Permian age, however, are generally unlike rocks of similar age previously mapped to the east in Idaho, but they resemble those to the south in Utah. The lowest Mississippian rocks, however, are correlated with the Lodgepole Limestone, which is the first use of this name in Idaho (Carr and Trimble, 1961). Part of the younger Mississippian rocks are assigned to the Deep Creek Formation (Carr and Trimble, 1961). Upper Mississippian, Pennsylvanian, and Permian rocks are correlated with similar strata in the Oquirrh Mountains, Utah (Gilluly, 1932), and are referred to the Great Blue Limestone, the Manning Canyon Shale, and the Oquirrh Formation. 
TABLE 1.-Formations of Paleozoic age exposed in the mapped area

\begin{tabular}{|c|c|c|c|c|c|}
\hline \multicolumn{2}{|l|}{ Age } & \multicolumn{2}{|r|}{ Unit } & \multirow{2}{*}{$\begin{array}{c}\begin{array}{c}\text { Thickness } \\
\text { (feet) }\end{array} \\
>1,090\end{array}$} & \multirow{2}{*}{$\begin{array}{c}\text { General } \\
\text { lithology } \\
\text { Bedded chert and limestone. }\end{array}$} \\
\hline Permian & Early & \multirow{4}{*}{$\begin{array}{l}\text { Oquirrh } \\
\text { Formation }\end{array}$} & Unit D & & \\
\hline \multirow{4}{*}{ Pennsylvanian } & \multirow[t]{2}{*}{ Late } & & Unit $\mathrm{C}$ & 1,910 & $\begin{array}{l}\text { Dark-gray limestone and } \\
\text { sandy limestone. }\end{array}$ \\
\hline & & & Unit B & 800 & $\begin{array}{l}\text { Sandstone and sandy } \\
\text { limestone. }\end{array}$ \\
\hline & \multirow{2}{*}{ Early } & & Unit A & $\approx 2,000$ & Limestone, tan-weathering. \\
\hline & & & Manning Canyon Shale & 1,160 & Shale and quartzite. \\
\hline \multirow{6}{*}{ Mississippian } & \multirow{5}{*}{ Late } & \multirow{3}{*}{$\begin{array}{l}\text { Great Blue } \\
\text { Limestone }\end{array}$} & Upper limestone member & 840 & Limestone. \\
\hline & & & Middle shale member & 430 & Shale. \\
\hline & & & Lower limestone member & 1,200 & Cherty limestone. \\
\hline & & \multirow{2}{*}{$\begin{array}{c}\text { Deep Creek } \\
\text { Formation }\end{array}$} & Upper chert-banded member & 1,500 & Chert-banded limestone. \\
\hline & & & Lower siltstone member & 760 & Siltstone, argillite, limestone. \\
\hline & Early & \multicolumn{2}{|r|}{ Lodgepole Limestone } & 370 & Limestone \\
\hline
\end{tabular}




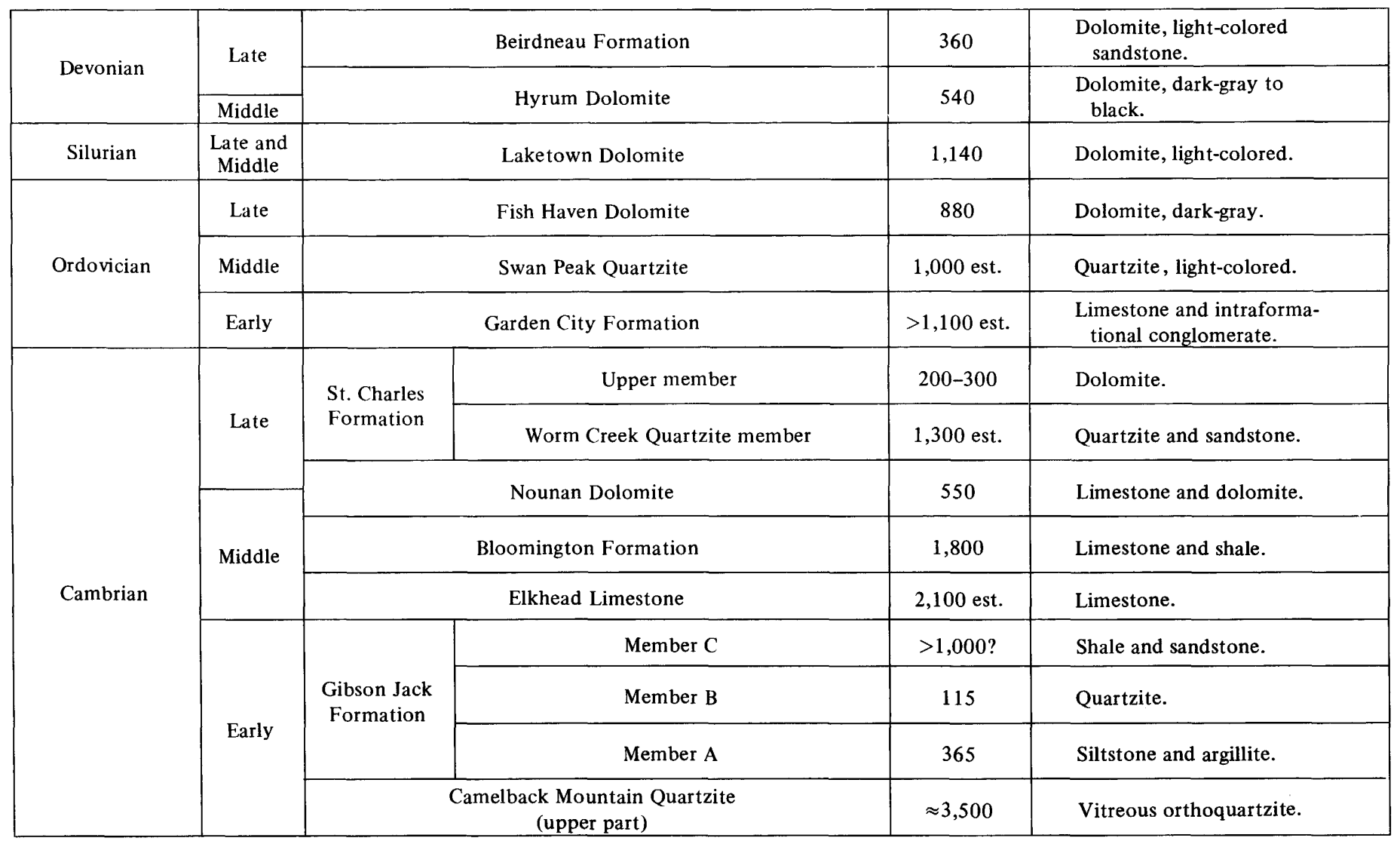


The names applied to the Tertiary and Quaternary formations are those previously used in the American Falls quadrangle (Carr and Trimble, 1963), north of the Rockland quadrangle (fig. 1).

The petrographic details of the igneous rocks and the conclusions drawn from them are of specialized interest and are therefore discussed separately. Most of the descriptive detail obtained from microscopic study and chemical analysis has been omitted from the section on stratigraphy, which is concerned mainly with a description of the megascopic features and the field relations of the rocks.

\section{CAMBRIAN SYSTEM}

Rocks of Cambrian age crop out in the northeastern part of the Arbon quadrangle, where about 7,500 feet of Cambrian rocks overlie a basal Cambrian quartzite. The rocks of the upper 6,000 feet of this sequence are lithologically similar in a general way to the well-known Cambrian section of northern Utah and southeastern Idaho originally described by Walcott (1908). The Upper and Middle Cambrian rocks of the Arbon quadrangle, however, contain unusual amounts of quartzite and sandstone.

Three names-the Camelback Mountain Quartzite (upper part), the Gibson Jack Formation (Crittenden and others, 1971), and the Elkhead Limestone (new in this report)-are used for the rocks of the lower part of the Cambrian sequence. The existing terminology from the Bear River Range in southeastern Idaho is used for the Middle and Upper Cambrian rocks, including the Bloomington and Nounan Formations and the Worm Creek Quartzite Member and the upper member of the St. Charles Formation.

\section{CAMELBACK MOUNTAIN QUARTZITE (UPPER PART)}

Rocks named the Camelback Mountain Quartzite occur in a small area near the north edge of the Arbon quadrangle west of Midnight Creek. The name is taken from Camelback Mountain, between North Fork and South Fork Pocatello Creek, in the Pocatello quadrangle. This name is used in preference to Brigham Quartzite because the term "Brigham" was applied in this area by Anderson (1928) and Ludlum $(1942,1943)$ to all of the rocks between the Blackrock Limestone of Anderson (1928) and the lowermost Cambrian limestone. Their Brigham included the Camelback Mountain Quartzite of this report, about 8,500 feet of rocks of Precambrian age that underlie the Camelback Mountain Quartzite, and about 1,500 feet of shaly rock interbedded with sandstone and quartzite that overlies the Camelback Mountain.

Only the upper part of the Camelback Mountain Quartzite is exposed in the Arbon quadrangle, but the unit is about 3,500 feet 
thick in the Pocatello quadrangle to the northeast, where it overlies Precambrian rocks.

The Camelback Mountain Quartzite in the mapped area is a medium-grained vitreous orthoquartzite that weathers tan to rusty brown. The quartzite here is mainly thick bedded to massive; some is crossbedded.

The upper contact of the Camelback Mountain is gradational and is mapped at the base of the first thick siltstone or argillite overlying the nearly continuous section of quartzite.

Fossils have not been found in the Camelback Mountain of this area, but, on the basis of its stratigraphic position, the entire formation may be of Early Cambrian and (or) Precambrian age. I believe, however, that it most probably is of Early Cambrian age.

\section{GIBSON JACK FORMATION}

Argillaceous siltstone, shaly argillite, and interbeds of quartzite and sandstone that overlie the Camelback Mountain Quartzite are named the Gibson Jack Formation (Crittenden and others, 1971). The type locality is adjacent to Gibson Jack Creek in the Pocatello quadrangle. These rocks formerly were included in the upper part of the Brigham Quartzite by Anderson (1928) and Ludlum (1942, 1943).

In the Arbon quadrangle the Gibson Jack Formation is exposed only along and west of Midnight Creek. Because shaly rocks predominate, especially in the upper two-thirds of the unit, it is poorly exposed nearly everywhere. Its thickness is not accurately known, but map measurements indicate that it probably is about 1,500 feet thick.

Three members of the Gibson Jack Formation have been mapped in most places and are designated, from oldest to youngest, as members $A, B$, and $C$.

Member A overlies the Camelback Mountain Quartzite and is 365 feet thick in the $\mathrm{NW}^{1 / 4} \mathrm{NE}^{1 / 4}$ sec. $7, \mathrm{~T} .8 \mathrm{~S}$., R. $34 \mathrm{E}$. The lower 30 feet of the member is quartzite and sandstone that contains interbeds of siltstone, mostly tan, but some purple and brown. The rest of member $A$ is argillaceous siltstone and shaly argillite containing some interbeds of sandstone and quartzite. The siltstone and argillite are mainly tan, olive, or gray green, but a few beds are purple or brown. Some beds are micaceous. The argillite is papery to shaly. The quartzite of member A is similar to that of the Camelback Mountain.

Member B of the Gibson Jack Formation is the lowest thick quartzite or sandstone in the shaly sequence above the Camelback Mountain. It is 115 feet thick in the NE ${ }^{1 / 4}$ sec. 7, T. 8 S., R. 34 E., but is probably cut off at the top by a fault at this locality. The 
quartzite or sandstone of member B is light gray, fine to medium grained, and thin bedded and weathers light tan, gray, or brown. Locally, it is so poorly cemented that it is a friable sandstone. Similar thick sandstone or quartzite units occur in member $\mathbf{C}$.

The upper two-thirds of the Gibson Jack Formation constitutes member $\mathrm{C}$, which probably is more than 1,000 feet thick. This member commonly is very poorly exposed and consists of shaly argillite and many interbeds of sandstone or quartzite, some of which are comparable in thickness to member B. At least two beds of tan-weathering very thin bedded argillaceous limestone, each tens of feet thick, occur near the top of member $\mathrm{C}$ but are so poorly exposed at most localities that they cannot be satisfactorily mapped.

The upper contact, rarely visible, is mapped at the base of a limestone unit several hundred feet thick that is the lower part of the overlying Elkhead Limestone.

Fossils were not found in the Gibson Jack Formation in the Arbon quadrangle, but in the Pocatello quadrangle a nontrilobite arthropod, Naraoia (identified by A. R. Palmer), previously known only in the Middle Cambrian Burgess Shale of British Columbia, and Protospongia were found near the top of member $\mathrm{A}$, and Protospongia was found only a few tens of feet above the base of the formation. Elsewhere (Oriel, 1965a), Olenellus has been found in rocks probably equivalent in part to the Gibson Jack Formation. The Gibson Jack is assigned to the Lower Cambrian on the basis of its possible correlation with the Olenellus-bearing beds. Lithologic equivalents of the Gibson Jack Formation are not known to be present elsewhere, unless part of the Gibson Jack is the lithogenetic equivalent of the Pioche Shale, as suggested by Maxey (1958, p. 649), and of the Lower Cambrian Cabin Shale and Busby Quartzite of northwestern Utah (Nolan, 1935; Staatz and Carr, 1964).

\section{ELKHEAD LIMESTONE}

The lowermost unit of Middle Cambrian age, composed mainly of limestone, is here namea the Elkhead Limestone. The name is taken from the Elkhead Ranch on Midnight Creek. This unit probably is equivalent to all of the Langston and Ute Limestones and the Blacksmith Limestone, which could not be discriminated in this area. The Elkhead Limestone is well exposed both east and west of Midnight Creek in the northern part of the Arbon quadrangle in secs. 7, 8, 17, and 18, T. $8 \mathrm{~S}$., R. $34 \mathrm{E}$., and this is designated the type locality. Its thickness, determined by map measurement, is about 2,100 feet.

The Elkhead is made up wholly of limestone except for a shale unit, about 100 feet thick, that occurs a few hundred feet above the base. The limestone, especially for a few hundred feet above this 
shale, is gray, thin bedded, ledge forming, and platy; the upper twothirds of the Elkhead is mainly thick-bedded to massive gray oolitic limestone. Yellowish-tan silty partings are common, and locally the unit contains intraformational conglomerate. The rock weathers gray to tannish gray and, locally, very light gray in the upper part.

The upper contact is at the base of the first green shale unit in the interbedded limestone and shale sequence that constitutes the overlying Bloomington Formation.

The shale unit a few hundred feet above the base of the Elkhead contains lower Middle Cambrian trilobites (Ehmaniella) of the Bathyuriscus-Elrathina zone, which are also present at the base of the Ute Limestone in Blacksmith Fork, Utah (A. R. Palmer, oral commun., 1963). Trilobites, which according to A. R. Palmer probably belong to the genus Alokistocare, were found 300-700 feet below the top of the formation on the ridge in the $\mathrm{SW}^{1 / 4}$ sec. $8, T$. 8 S., R. 34 E. (USGS colln. 2462-C0, 3643-CO). Another collection from about $\mathbf{1 7 0}$ feet below the top of the formation (USGS colln. 2643-CO) contained trilobites belonging to generalized groups often referred to as Ehmania and Solenopleura. These collections indicate a Middle Cambrian age for the Elkhead Limestone and probable equivalence of the fossiliferous part of the unit to the Ute Limestone and the Blacksmith Limestone. Limestone below the shale, which so far has not yielded fossils, may be equivalent to the Langston Limestone.

\section{BLOOMINGTON FORMATION}

The Bloomington Formation is a distinctive sequence of interbedded shale and limestone. It overlies the Elkhead Limestone east of Midnight Creek, and is exposed in several small areas along Rattlesnake Creek. The unit is 1,800 feet thick, as measured in the $\mathrm{S} 1 / 2$ sec. 8 , T. 8 S., R. 34 E. (measured section 2 ).

Limestone of the Bloomington is oolitic, gray to blue gray, and interbedded in nearly equal amounts with tannish-green to olive-drab shale, argillite, and siltstone. Brown to reddish-brown fine- to medium-grained quartzite more than 80 feet thick occurs about 700 feet above the base. Much of the limestone has yellowish-orange silty laminae and partings. The limestone in the upper half of the unit contains much intraformational conglomerate. The shale, argillite, and siltstone units contain abundant nodules of pale-green dense fine-grained limestone. These nodules have been noted elsewhere by others (R. C. Bright, written commun., 1960; Olson, 1956, p. 48) in rocks of about the same stratigraphic position.

The lower contact is drawn at the base of the first shale or siltstone above the thick-bedded to massive carbonate beds of the Elkhead Limestone. 


\section{GEOLOGY, ROCKLAND AND ARBON QUADRANGLES, IDAHO}

Tribolites and primitive brachiopods (USGS collns. 3640-CO, 3641-CO, and 3642-CO), indicating late Middle Cambrian age, were obtained from a sequence of rocks about 140 feet thick, the top of which is 190 feet below the top of the formation. Numerous algae (Girvanella?) as much as half an inch in diameter occur at several horizons in the formation. The fossils and lithology of the Bloomington Formation in other areas. The Bloomington in the Arbon quadrangle is more than $\mathbf{4 0 0}$ feet thicker, however, than the Bloomington in other parts of southeastern Idaho, and it includes a prominent quartzite unit not present to the east and south. The only other occurrence of quartzite in rocks of this approximate age known to us is in the Lamb Dolomite of Middle (?) and Late Cambrian age of the Dugway Range of western Utah (Staatz and Carr, 1964). The quartzite in the Lamb, however, is probably of early Late Cambrian age.

\section{NOUNAN DOLOMITE}

The Nounan Dolomite consists of limestone, sandstone, and dolomite that overlie the shaly sequence of the Bloomington (fig. 3). It is exposed east of Midnight Creek, on the west side of Flatiron Hill, and on the north side of the large hill between Starlight and

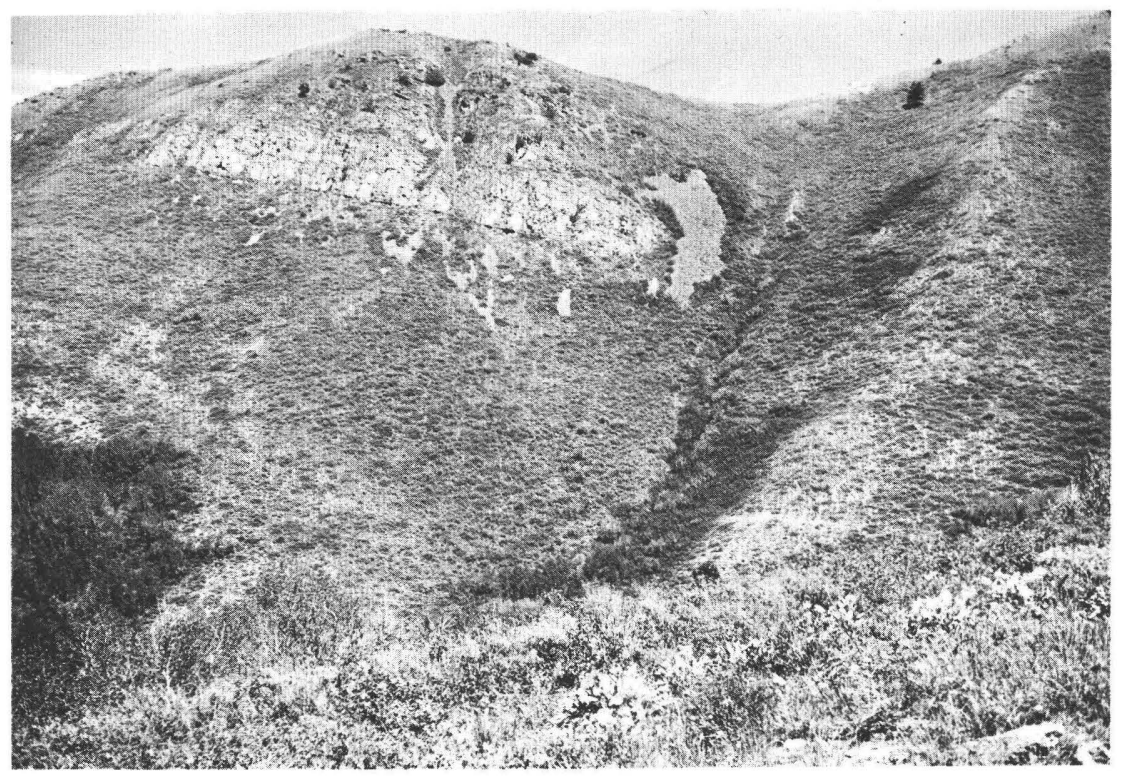

F IGURE 3.-Middle and Upper Cambrian Nounan Dolomite forms ledge above covered slope of upper part of the Bloomington Formation east of Midnight Creek in the $\mathrm{NW}^{1 / 4}$ sec. 17, T. 8 S., R. $34 \mathrm{E}$. 
Moonshine Creeks, and also crops out in small areas about 1 mile south of Rattlesnake Creek, all in the northern part of the Arbon quadrangle. The formation is about 550 feet thick. In measured section 2 the Nounan is only 440 feet thick, but about 100 feet of limestone is estimated to have been cut out by a small fault.

The lower 135 feet of the Nounan is composed of gray to blue-gray limestone and sandy dolomite that is thin bedded and oolitic in part and contains pink and yellow silty partings. This is overlain by more than 80 feet of tan, brown, and reddish fine-grained sandstone. Above the sandstone is about 100 feet of thin-bedded gray oolitic limestone that is overlain by more than 200 feet of limestone and dolomite, some of which is a distinctive pale pink to pinkish gray.

The lower contact is placed at the top of the highest shale or siltstone in the conformably underlying Bloomington.

Fossils were not found in the Nounan, but its lithology and stratigraphic position indicate that it is at least partly equivalent to the Nounan Dolomite of Middle and Late Cambrian age in other areas of southeastern Idaho. It is about 300-500 feet thinner in the Arbon quadrangle, however, than the Nounan elsewhere. Pastelcolored beds are a feature of Upper Cambrian rocks which has not been emphasized by previous workers in this region, although Staatz and Carr (1964) found this to be a distinctive feature of the middle part of the Upper Cambrian in the Dugway Range, Utah. Pink limestone has been observed in a unit equivalent to the Nounan in the Portneuf Range 20 miles east of Midnight Creek (D. A. Holmes and L. O. Storey, written commun. 1958, 1959).

\section{ST. CHARLES FORMATION}

The St. Charles Formation is the youngest Cambrian formation. The St. Charles was named by Walcott (1908) from its occurrence in the Bear River Range west of the town of St. Charles, Bear Lake County, Idaho. The St. Charles consists of the Worm Creek Quartzite Member and an upper member.

\section{WORM CREEK QUARTZITE MEMBER}

The Worm Creek Quartzite Member of the St. Charles Formation overlies the Nounan and crops out in the same general areas. The name Worm Creek was applied to a quartzite unit considered to be a basal member of the St. Charles Limestone by Richardson (1913). As determined from map measurement, the unit is about 1,300 feet thick in the Arbon quadrangle.

Clastic beds in the lower 400 feet of the Worm Creek are mainly $\tan$ to red fine- to medium-grained feldspathic crossbedded 
sandstone. A sequence more than 100 feet thick of silty and sandy gray dolomite occurs within this lower part. The upper part of the lower 400 feet of the member is dolomite, more than 100 feet thick, that weathers to a cream color. It overlies sandstone in the lower part of the member and underlies quartzite that constitutes most of the rest of the Worm Creek. Quartzite in the upper part of the member is mostly tan and fine to medium grained. The sandstone and quartzite of the Worm Creek are characterized by grains of potash feldspar that weather white and give the rock a spotted or speckled appearance. Feldspar grains distinguish the quartzite of the Worm Creek from the younger Swan Peak Quartzite of Ordovician age, for which it might otherwise be mistaken in isolated exposure.

The lower contact is conformable and is placed at the base of the lowest sandstone above the pink limestone and light-colored dolomite of the Nounan. Commonly, the basal sandstone is feldspathic and crossbedded.

Fossils were not found in the Worm Creek, but its lithology and stratigraphic position indicate that it is approximately equivalent to the Worm Creek Quartzite Member of the St. Charles Formation of Late Cambrian age (Richardson, 1913). The Worm Creek of the Bannock Range is, however, more than three times as thick as the thickest section of Worm Creek reported (Richardson, 1941, p. 13) from the Bear River Range, where it was named, and is 400 feet thicker than the Worm Creek in the Portneuf Range 30 miles to the east of the Arbon quadrangle (Oriel, 1965b).

\section{UPPER MEMBER}

The youngest Cambrian unit consists of dolomite that overlies the Worm Creek Quartzite Member and is here assigned to the upper member of the St. Charles Formation. It is poorly exposed in several areas between Midnight Creek and Crystal Creek and probably is present in a small exposure south of Rattlesnake Creek. Forty-six feet of the upper member of the St. Charles also crops out in the southwest base of the hill between Starlight Creek and Moonshine Creek, west of Bannock Creek, where it is overlain by Garden City Limestone.

The upper member of the St. Charles was not measured in the field, but it is estimated to be at least 200 feet thick. Because of faulting and poor exposure of the rocks, this estimate may be considerably in error.

The dolomite of the upper member is mostly gray with a few beds of dark gray. It is thin to medium bedded and cherty. Tan to pink chert nodules are common, especially in the upper part of the unit. 
Locally a brown silica fretwork occurs along the bedding planes. Gray limestone beds occur locally. Algal pisolites are common.

The lower contact is conformable and is placed at the top of the quartzite of the Worm Creek. The top of the Cambrian section is at the top of the dolomite of the St. Charles and at the base of the conformably overlying Garden City Formation of Ordovician age, but, because of local interbedding of dolomite and limestone in the upper member of the St. Charles and because of local irregular dolomitization in the Garden City Formation, this contact can be located only very approximately.

Fossils were not obtained from the upper member of the St. Charles in this area, but its lithology and stratigraphic position indicate that it is equivalent to the upper member of the St. Charles Formation of Late Cambrian age elsewhere.

\section{ORDOVICIAN SYSTEM}

The rocks of Ordovician age comprise the Garden City Formation, the Swan Peak Quartzite, and the Fish Haven Dolomite. These units, first defined by Richardson (1913) in the Bear River Range west of Bear Lake, are widespread in southeastern Idaho (Mansfield, 1920, 1927), and northern Utah.

\section{GARDEN CITY FORMATION}

The Garden City Formation is poorly exposed at several places east of Bannock Creek, mostly north of Rattlesnake Creek. West of Bannock Creek the formation is exposed on two hills on either side of Starlight Creek. No continuous section of the Garden City is present in the two quadrangles. The most nearly complete section is east of Crystal Creek, where the top of the formation is present, but the base is cut off by a fault. The lower part of the formation is well exposed, but faulted, on the southwest flank of the big hill between Starlight and Moonshine Creeks. In the Arbon quadrangle the Garden City is estimated to be 1,200 feet thick or less.

The Garden City is mainly blue-gray fine- to medium-grained slabby limestone. The lower 500 feet contains much intraformational conglomerate, and some bioclastic layers. Chert is not abundant in the lower part, but in the Crystal Creek area there is much layered black chert in the upper 100 feet of the formation.

The limestone of the Garden City has been dolomitized locally, but dolomite, 46 feet thick, beneath the base of the Garden City Limestone section on hill 5,539 in sec. 32 , T. 8 S., R. 33 E., has been assigned to the upper part of the St. Charles Formation of Cambrian age. The presence of chert nodules in the dolomite and their absence 
in the overlying beds which contain a Garden City fauna, together with the abrupt change from dolomite to limestone that is unquestionably part of the Garden City, suggests that the dolomite there is Cambrian.

A trilobite faunal assemblage was obtained from the lower 200-300 feet of the Garden City Formation in sec. 32, T. 8 S., R. 33 E. It is typical of zone B of the Garden City (R. J. Ross, 1951) in nearby areas of Utah and southeastern Idaho (R. J. Ross, written commun., 1961). The formation is Early Ordovician in age.

\section{SWAN PEAK QUARTZITE}

The Swan Peak Quartzite is exposed in the same general areas as the Garden City Formation. It also crops out at White Quartz Mountain, in a small area west of Sunbeam Creek near the north edge of the Rockland quadrangle, and at many places north of Pauline (fig. 4) and east of the valley of Bannock Creek. The quartzite forms conspicuous cliffs in some parts of the area, such as White Quartz Mountain, which has the most complete section of the formation. The Swan Peak is about 1,000 feet thick.

The Swan Peak Quartzite has a thin basal zone, less than 30 feet thick, of quartzitic siltstone and minor gray-green to tan chloritic shale. The rest of the formation is massive to thick-bedded white to yellowish-tan quartzite, except for some slightly dolomitic sandstone

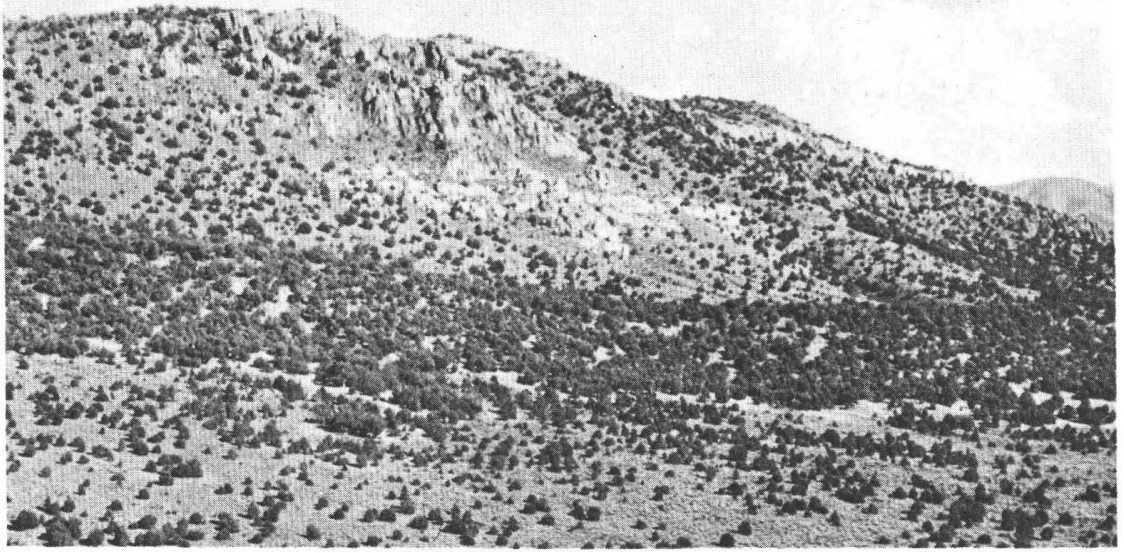

Figure 4.-Swan Peak Quartzite and overlying Fish Haven Dolomite in hill 11/2 miles north of Pauline, in the Arbon quadrangle. 
in the upper 10 feet, just below the Fish Haven dolomite. The quartz grains are medium size and well sorted.

Although the Swan Peak has yielded fossils in other places, none was found in the formation in this area. R. J. Ross (1951) has shown that the Swan Peak is of earliest Middle Ordovician age.

\section{FISH HAVEN DOLOMITE}

The Fish Haven Dolomite is the youngest of the Ordovician strata in this region. It overlies the Swan Peak Quartzite at many localities. In the saddle directly east of White Quartz Mountain, the Fish Haven has been faulted out and the Laketown Dolomite is in fault contact with the Swan Peak Quartzite, but the Fish Haven appears downslope both to the north and to the south of the saddle. North of Bannock Peak, and at several places east of Bannock Creek, the Swan Peak Quartzite has been thrust over Fish Haven. The Fish Haven is present in small exposures northwest of Garden Ranch, in the northeastern part of the Rockland quadrangle. It is also exposed at many localities east of Bannock Creek in the Arbon quadrangle, where the measured thickness is 870 feet (fig. 5; measured section 3).

The lower half of the Fish Haven is a rather uniform medium-gray to dark-gray fine- to medium-grained dolomite that locally contains abundant chert nodules or stringers and forms conspicuous ledges. The lower 20 feet is commonly a very sandy dolomite or dolomitic sandstone. The upper half of the formation consists of two parts-a lower unit of gray dolomite, some of which is rather thin bedded, together with several ledges of very light gray dolomite, and an upper unit of faintly mottled gray dolomite that becomes lighter upwards.

The contact with the overlying Laketown is placed at the top of the highest dark dolomite. The color change to light-gray dolomite in the overlying Laketown is rather gradational, and the position of the contact may vary considerably from place to place. The lower contact with the Swan Peak Quartzite is at the top of the uppermost quartzite and is gradational to dolomite-cemented sandstone in the lower 20 feet of the Fish Haven.

The Fish Haven contains an abundant coral and brachiopod fauna of Late Ordovician age. The corals weather white and stand out prominently against the dark dolomite. One of the largest collections of Ordovician brachiopods from a western locality, according to R. J. Ross (oral commun., 1966), was obtained from light-gray dolomite in the upper part of the Fish Haven in a saddle just north of the boundary of the Fort Hall Indian Reservation in the $\mathrm{SE}^{1 / 4}$ sec. 35, T. 9 S., R. 33 E. 


\section{SILURIAN SYSTEM \\ LAKETOWN DOLOMITE}

The Silurian System is represented by one formation in southeastern Idaho-the Laketown Dolomite, named by Richardson (1913). The type locality is Laketown Canyon, Utah, at the south end of Bear Lake. The Laketown is present in the Rockland-Arbon quadrangles in the same general localities as the Swan Peak Quartzite and the Fish Haven Dolomite. The thickness of the Laketown measured east of Bannock Creek is 1,136 feet (measured section 4).

Nearly all the Laketown Dolomite is a distinctive uniform light-gray fine- to medium-grained dolomite, but the upper 400 feet contains some beds of darker dolomite.

The lower contact with the Fish Haven Dolomite is the contact of light-gray dolomite with mottled-gray dolomite of the Fish Haven and appears to be gradational.

Diagnostic fossils were not found in the Laketown in this area, but the lithology is characteristic of the formation elsewhere in the region (Richardson, 1941, p. 18; Williams, 1948, p. 1137; C. P. Ross, 1947, p. 1105-1106) where it is Middle and Late Silurian in age.

\section{DEVONIAN SYSTEM}

Devonian rocks of this area total 900 feet in thickness and are assigned to two formations, the Hyrum Dolomite (Upper Devonian) and the Beirdneau Formation (Upper Devonian). The names Hyrum and Beirdneau were applied by Williams (1948) to units in the Bear River Range in the Logan quadrangle, Utah. He considered these units to be the lower and upper members of the Jefferson Formation, respectively. The Beirdneau has been shown to be younger than the uppermost part of the Jefferson Formation, the Birdbear Member (Benson, 1966), and now is thought by some to be equivalent to the Three Forks Formation of Late Devonian age. This possibility was noted by Williams (1948, p. 1140). The Beirdneau and Hyrum, therefore, are considered to be separate formational units.

\section{HYRUM DOLOMITE}

The Hyrum Dolomite is extensively exposed in the Arbon quadrangle in the Bannock Peak area and east of Squaw Creek. It also crops out at several places east of Bannock Creek and at one place in the Rockland quadrangle near the mouth of Hunter Canyon. The formation is 542 feet thick east of Bannock Creek (measured section 4). 


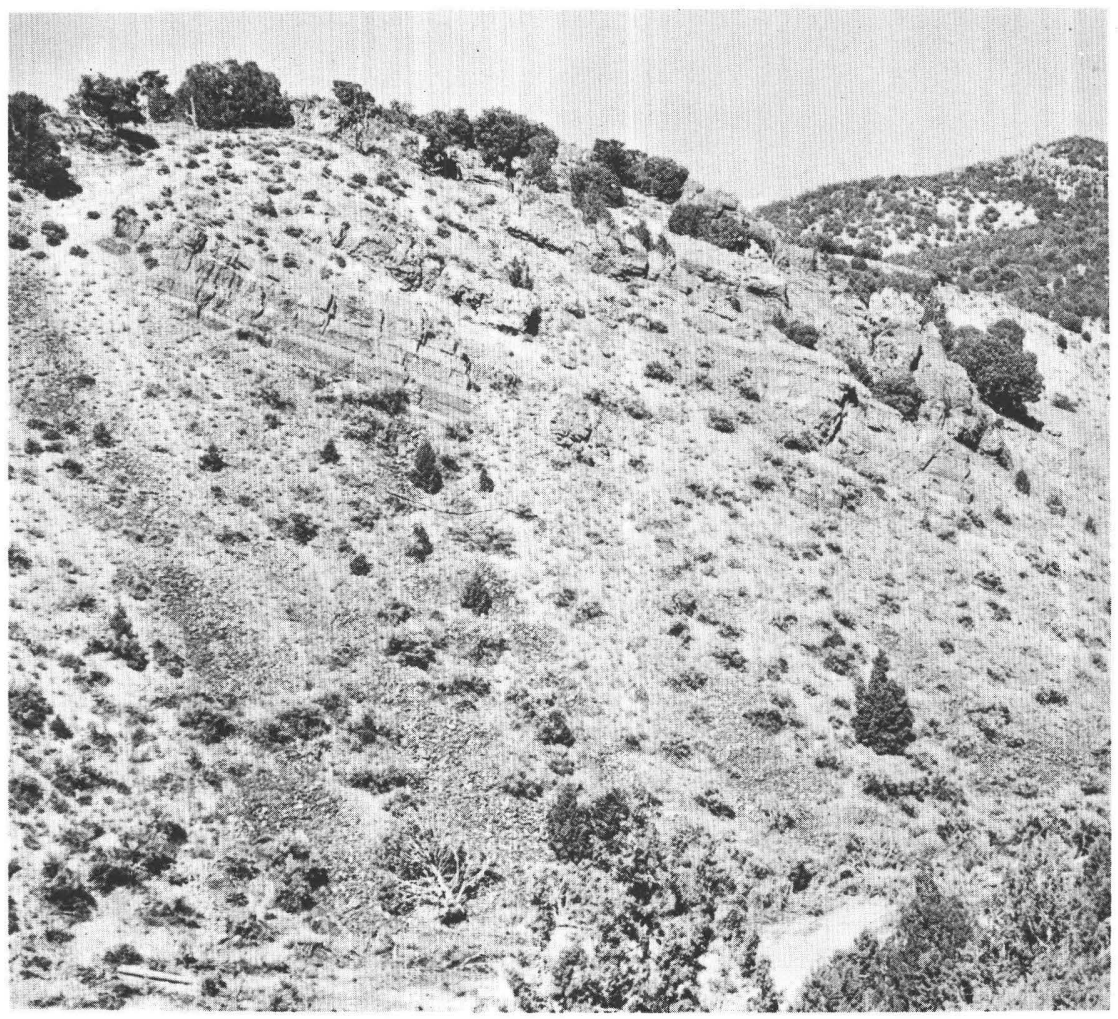

F IGURE 5.-Hyrum Dolomite east of Bannock Creek in sec. 23, T. 9 S., R. 33 E., Arbon quadrangle.

The Hyrum Dolomite is mainly dark-gray to black dolomite, mostly medium grained, that weathers dark gray to light gray and locally contains some intraformational breccia. Some of the beds form prominent ledges (fig. 5). The Hyrum Dolomite in the saddle between White Quartz Mountain and Bannock Peak lacks the very dark dolomite typical of the formation elsewhere, but the dark-gray to black dolomite is present downslope to the north.

The lower contact of the Hyrum is placed at the base of the stratigraphically lowest very dark gray or black dolomite in a nearly continuous conformable sequence of dolomite. Amphipora, where present, aids in the recognition of the Hyrum. The lower contact of the Hyrum west of Bannock Peak was placed at the change from light-colored dolomite assigned to the Laketown to somewhat darker beds assigned to the Hyrum.

Fossils found in the Hyrum are poorly preserved and mostly indeterminate. Amphipora found in some beds indicates a Devonian age (J. T. Dutro, Jr., and W. J. Sando, oral commun., 1958). 


\section{BEIRDNEAU FORMATION}

The Beirdneau Formation overlies the Hyrum Dolomite and is coextensive with it. The Beirdneau is 360 feet thick where it was measured east of Bannock Creek (measured section 4).

The Beirdneau Formation consists of dolomitic sandstone, quartzite, light-bluish-gray dolomite, and minor limestone. At the base of the formation in the measured section is a bed about 14 feet thick of light-tan fine-grained quartzite. Sandstone and quartzite locally occur sparsely, interbedded with dolomite, through the lower 200 feet of the formation, but along Moonshine Creek the lower 100 feet is mainly sandstone and quartzite. The upper 100 feet commonly is a light-bluish-gray dolomite with sandy laminae that stand out in relief along bedding planes. At the top of the Beirdneau west of Bannock Peak is thin-bedded platy light-gray dolomite, several feet thick, that weathers nearly white. This lithology was also seen locally east of Squaw Creek in the Arbon quadrangle, and a similar bed was present in the American Falls quadrangle (Carr and Trimble, 1963) in about the same stratigraphic position. Elsewhere, this bed is absent.

The Beirdneau Formation of the Arbon quadrangle is much like that in the southeastern part of the Logan quadrangle, Utah, where, according to Mullens and Izett (1964, p. S5), the Beirdneau is 500-710 feet thick and consists of interbedded sandstone, siltstone, and dolomite in the lower 600 feet, and consists of dolomitic sandstone that contains thin beds of fine-grained quartz sandstone in the upper 100 feet.

The lower contact of the Beirdneau is placed at the base of the lowest sandstone or quartzite bed above the dark dolomite of the Hyrum.

Fossils were not found in the Beirdneau, but it probably is Late Devonian if it is equivalent to the Three Forks Formation as suggested by Benson (1966).

\section{MISSISSIPPIAN SYSTEM}

Mississippian rocks in the Deep Creek Mountains are nearly 6,000 feet thick. They are subdivided into the Lodgepole Limestone, Deep Creek Formation, Great Blue Limestone, and Manning Canyon Shale, which is partly of Pennsylvanian age.

\section{LODGEPOLE LIMESTONE}

The name Lodgepole Limestone was first used by Collier and Cathcart (1922) who subdivided the Madison Group in the Little Rocky Mountains in Montana. Because the rocks of Early Mississippian age in the Rockland-Arbon area are lithologically 
similar to, and of the same age as, the Lodgepole of other areas, the name has been applied (Carr and Trimble, 1961) to the fossiliferous limestone that immediately overlies the Beirdneau Formation. The Lodgepole is the oldest formation of Paleozoic age exposed on the west side of the Deep Creek Mountains north of Hunter Canyon. It overlies the Beirdneau on both the west and east sides of Bannock Peak, and at several places east of Squaw Creek. It also forms part of the ridge crest east of Bannock Creek, in secs. 12 and 13, T. 9 S., R. $33 \mathrm{E}$., and at several other localities in the northeastern part of the same township.

The thickness of the Lodgepole Limestone is rather variable. A thickness of 368 feet measured north of Hunter Canyon (measured section 5) probably represents most of the formation there, although the base is not exposed. In the saddle west of Bannock Peak, however, the unit is only a few tens of feet thick. East of Bannock Creek it may be more than 1,000 feet thick. The cause of these great differences in thickness is not known. Some sections are undoubtedly thinned by faulting, but locally there appears to be an unconformity at the base of the Lodgepole. The lack of cherty strata at the top of the formation in some localities and their presence elsewhere suggests the possibility of an unconformity at the top of the formation, but this relation may also be explained by nondeposition, or, perhaps more likely, by cutting out of the upper part of the formation by local thrusting.

In most places the Lodgepole Limestone is gray to black fine-grained limestone that weathers gray to brownish gray. It locally is abundantly fossiliferous. The lower third of the Lodgepole north of Hunter Canyon, however, is a light-bluish-gray finely crystalline saccharoidal dolomite. This rock is adjacent to the frontal fault zone of the Deep Creek Mountains and may be altered by secondary dolomitization. Minor amounts of dolomite occur near the base of the Lodgepole at a few other places as well. Chert is locally abundant at both the top and bottom of the Lodgepole, especially east of Bannock Creek.

The lower contact in most places is at the top of the light-bluish-gray dolomite in the upper part of the Beirdneau. Abundant chert at the base of the Lodgepole at some places helps in placing the contact with the underlying Beirdneau Formation.

Both the limestone and the dolomite at the base of the Lodgepole in the Hunter Canyon section contain fossils of Early Mississippian age, but elsewhere in the area fossils have not been found in dolomite underlying the limestone of the Lodgepole. According to W. J. Sando (written commun., 1964), the Lodgepole Limestone north of Hunter Canyon contains coral faunas in the interval 20 feet 
above the base to about 100 feet below the top that are all characteristic of Madison Zone $\mathrm{C}_{1}$ of Sando and Dutro (1960). Zone $\mathrm{C}_{1}$ occupies approximately the upper two-thirds of the Lodgepole Limestone of southwest Montana, western Wyoming, and northeast Utah. Zone $\mathrm{C}_{1}$ is of Early Mississippian age and is thought to represent the lower part of the Osagean and uppermost part of the Kinderhookian Series. The absence of zones A and B in the Hunter Canyon measured section may be the result of truncation by a range-front fault (Sando, 1967). A brachiopod fauna from the lower part of the limestone at Hunter Canyon is of probable Kinderhookian age (J. T. Dutro, Jr., written commun., 1958). The absence of Madison Zones $\mathrm{C}_{2}$ and $\mathrm{D}$ corals suggests that there may be a hiatus between the Lodgepole and the overlying Deep Creek Formation (Sando, 1967), such as is thought to exist between the Lodgepole and the Little Flat Formation in the Chesterfield Range, southeast Idaho (Dutro and Sando, 1963; Sando and others, 1969).

\section{DEEP CREEK FORMATION}

More than 2,000 feet of rocks above the Lodgepole Limestone is assigned to the Deep Creek Formation (Carr and Trimble, 1961). The type section is at Hunter Canyon in the Rockland quadrangle (measured section 5). The Deep Creek Formation is also exposed near and on Bannock Peak. It is extensively exposed east of Squaw Creek and in several localities eastof Bannock Creek. The formation is 2,260 feet thick at Hunter Canyon and about the same thickness on Bannock Peak.

The Deep Creek Formation is divided into two members, a lower siltstone and an upper chert-banded limestone. The lower member is 760 feet thick at Hunter Canyon and consists mainly of light-gray to brown or black siltstone that weathers brown or purplish gray and that is interbedded with subordinate silty limestone, fine-grained sandstone, and shale. On Bannock Peak it consists mainly of shale and siltstone. Thick shale exposed near the spring southwest of Bannock Peak, however, is atypical of the unit. The upper member, 1,500 feet thick at Hunter Canyon, is gray to blue-gray mostly thinto medium-bedded limestone that contains much dark chert in nodules and bands. The upper member locally is silty and platy and weathers purplish. On Bannock Peak and at some places east of Bannock Creek the lower two-thirds of the limestone in the upper member is sandy. East of Bannock Creek it locally becomes very silty, and some of the upper member is siltstone much like that in the lower member.

The lower contact of the formation is placed at the base of the first shale or siltstone above the Lodgepole Limestone. 
The Deep Creek Formation is the temporal and lithologic equivalent of the Little Flat Formation of the Chesterfield Range of southeastern Idaho, which is middle Meramecian (Late Mississippian) in age (Sando, 1967, p. D35, D36; Sando and others, 1969). The Deep Creek is also approximately equivalent to the Humbug Formation and the Deseret Limestone of the Oquirrh Range, Utah (Gilluly, 1932).

\section{GREAT BLUE LIMESTONE}

The term "Great Blue Limestone" was originally applied by Spurr (1895) to rocks in the Mercur mining district in the southern Oquirrh Mountains, Utah. The formation was redefined by Gilluly (1932), who separated from the Great Blue of Spurr the upper part which he named the Manning Canyon Shale. The Great Blue Limestone is exposed in the Rockland-Arbon quadrangles on the west side of the Deep Creek Mountains between Hunter Canyon and Well Canyon, in several areas east of Squaw and Bannock Creeks, and in a small area in the southeast corner of the Arbon quadrangle. The Great Blue is about 2,500 feet thick on the west side of the Deep Creek Mountains. This thickness differs from the 1,200 feet shown in the diagrammatic columnar section of Carr and Trimble (1961, fig. 213.1) because the boundary between the Great Blue Limestone and Manning Canyon Shale as used here is at the top of a limestone unit previously assigned by us to the Manning Canyon Shale.

The Great Blue Limestone of the Deep Creek Mountains is lithologically similar to the type Great Blue. In the Oquirrh Mountains, Utah, Gilluly (1932) recognized a lower limestone, a middle shale that he named the Long Trail Shale Member, and an upper limestone. The Great Blue in the Deep Creek Mountains similarly may be divided into lower and upper limestone members divided by a thick middle shale member (measured sections 5 and 6 ). The lower limestone member, 1,195 feet thick, is light gray to gray or blue gray, medium to coarse grained, and mostly massive to thick bedded. Locally, it contains chert nodules and abundant fossil debris. Large productids occur abundantly in a thin zone about 400 feet above the base. Some of the limestone is silty or sandy, and some is thin bedded. Much of the limestone has a mottled very light gray weathered surface. Midway in the lower limestone is 183 feet of dark-gray shale and interbedded limestone.

Above the lower limestone is more than 400 feet of gray, black, brown, and greenish-gray shale of the middle shale member (fig. 6) that contains a few thin beds of brown quartzite and abundant concretions of limestone in the lower 200 feet and interbeds of sandy and argillaceous limestone in the upper 200 feet. The shale weathers tan to dark brown. This shale mostly forms smooth, covered slopes. 


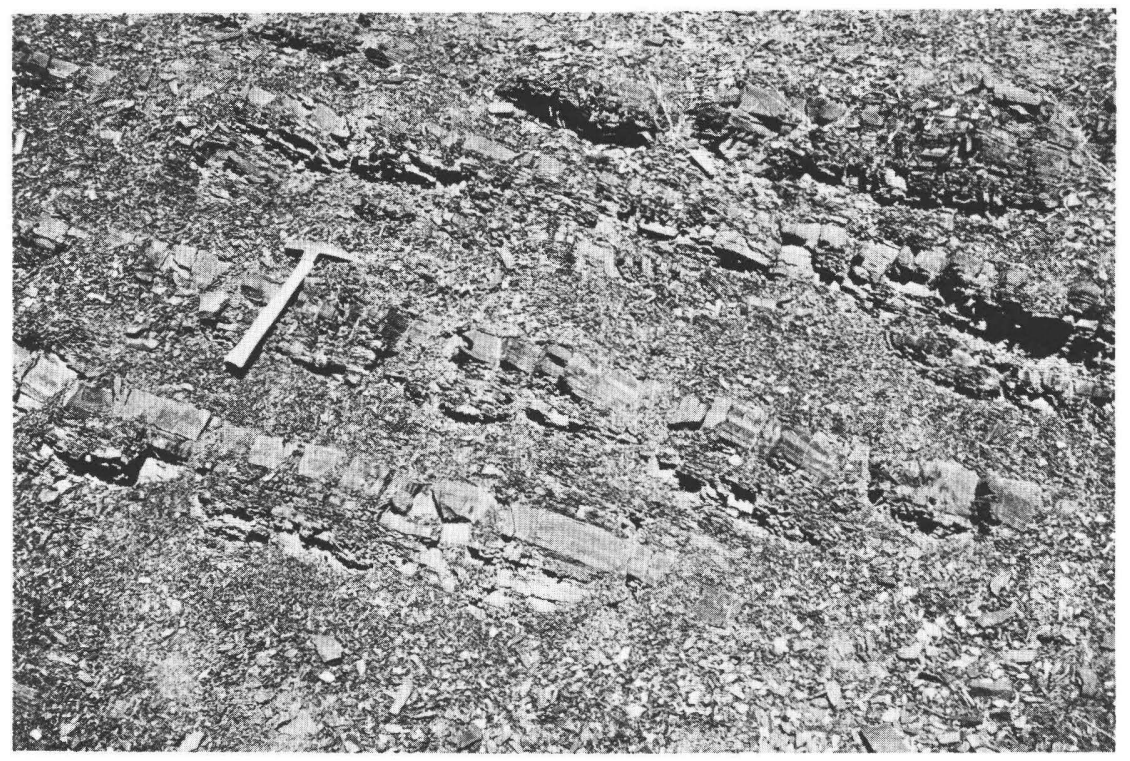

FiguRE 6.-Middle shale member of the Great Blue Limestone north of Hunter Canyon, in the SW ${ }^{1 / 4}$ sec. 25 , T. 9 S., R. 31 E., Rockland quadrangle.

The upper limestone member of the Great Blue is about 850 feet thick. It is rather thin bedded, light gray to dark gray or black, and cherty. The upper part has irregular bedding and a nodularweathered surface. The unit is characterized by nodules and bands of black chert and dolomite that have distinctive markings somewhat like Liesegang rings. This oddly marked black chert and dolomite is also present in the upper limestone member in the Oquirrh Mountains, Utah.

The lower contact of the Great Blue is placed at the base of the first ledge of massive limestone above the thin- to medium-bedded cherty limestone of the upper member of the Deep Creek Formation. Large horn corals (Faberophyllum) characteristic of the Great Blue commonly are present in the lower part and aid in placing this contact (fig. 7). The nodular character of the chert also helps distinguished the Great Blue from the upper member of the Deep Creek, which commonly has chert in beds, bands, or stringers.

The Great Blue Limestone in the Deep Creek Mountains contains an abundant fauna. According to W. J. Sando and J. T. Dutro, Jr. (written commun., 1961), the fossils from beds immediately above the Deep Creek Formation are entirely consistent with a Great Blue identification. The assemblage from these collections is characterized by the coral Faberophyllum, which is the index genus for the Zone F of the Chesterfield Range Group (Dutro and Sando, 


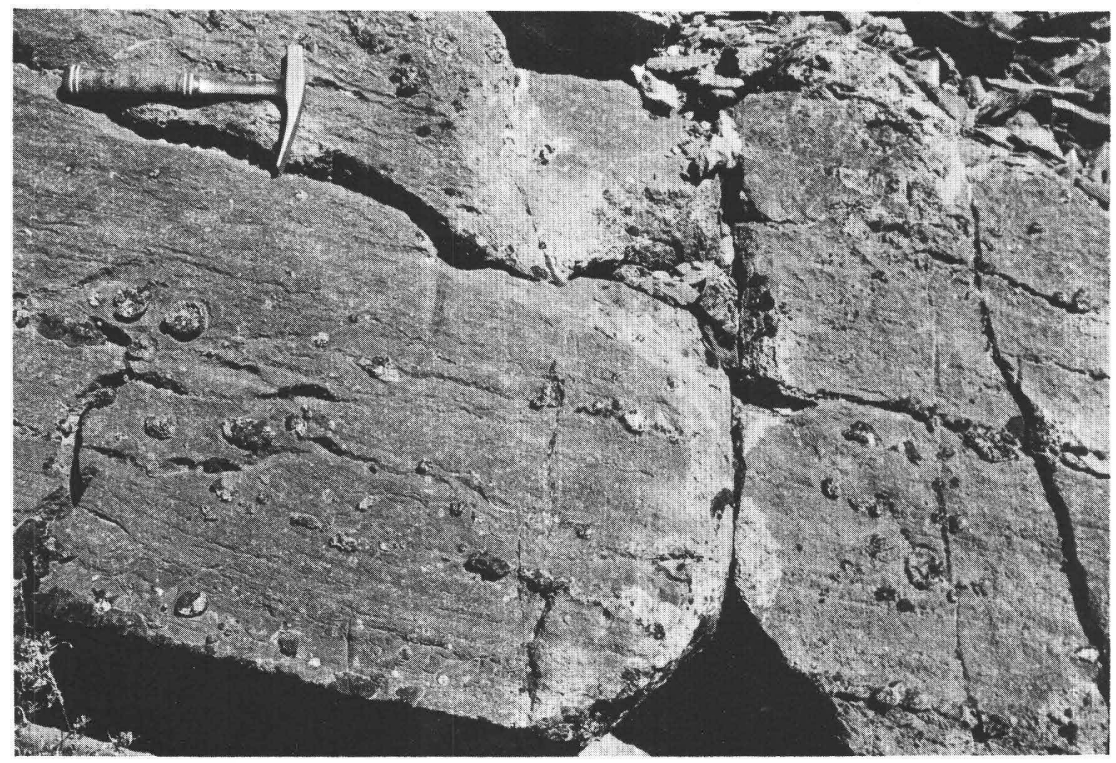

FIGURE 7.-Faberophyllum near base of the Great Blue Limestone north of Hunter Canyon, in the SW $1 / 4$ sec. 26, T. 9 S., R. 31 E., Rockland quadrangle.

1963), and brachiopods Ovatia sp., Inflatia sp., Spirifer aff. S. pellaensis Weller, and Dimegelasma ef $D$. eurkensis Lintz and Lohr. These fossils are thought to be of late Meramecian age. The highest collection of corals from the Hunter Canyon section (measured section 5) contains Caninia related to $C$. excentrica (Meek), which marks Zone $\mathrm{K}$ in the Chesterfield Range Group (Dutro and Sando, 1963). According to W. J. Sando (written commun., 1964) the Great Blue Limestone of the Deep Creek Mountains is approximately equivalent to the Monroe Canyon Formation of the Chesterfield Range and is of Meramecian and Chesterian age.

The name Great Blue has been applied to rocks in the Promontory Mountains, Utah (Olson, 1956), about 80 miles south of the Deep Creek Mountains of Idaho. Rocks in the Deep Creek Mountains that are called Great Blue are correlative with parts of the section called Brazer Limestone in southeastern Idaho (Mansfield, 1920, 1927; F. C. Armstrong, 1953) and in central Idaho (C. P. Ross, 1947) and with the Monroe Canyon Formation of the Chesterfield Range, Idaho (Dutro and Sando, 1963).

\section{MISSISSIPPIAN AND PENNSYLVANIAN SYSTEMS}

\section{MANNING CANYON SHALE}

The term "Manning Canyon Shale" was applied by Gilluly (1932) to rocks in the Oquirrh Mountains, Utah, that were originally included 
by Spurr (1895) in the Great Blue Limestone. The Manning Canyon Shale overlies the Great Blue Limestone on the west side of the Deep Creek Mountains, Idaho, between Hunter Canyon and Well Canyon and is present along Squaw Creek east of Bannock Peak. Exposures of Manning Canyon Shale are present also at two places just outside the Arbon quadrangle-one east of the southeast corner, the other south of the mouth of Knox Canyon. Nearly 1,200 feet of Manning Canyon Shale was measured north of Well Canyon (measured section $6)$.

The Manning Canyon Shale consists of dark-gray or black to varicolored shale and argillite interbedded with limestone, siltstone, sandstone, and quartzite. The quartzite is mainly in the lower 100 feet and in the upper 150 feet. Some thin beds above and below the lower quartzite beds are phosphatic and locally contain as much as 30 percent $\mathrm{P}_{2} \mathrm{O}_{5}$. The limestone is mainly in the upper part of the formation.

The lower contact of the Manning Canyon Shale is placed at the abrupt contact between the upper limestone member of the Great Blue and the dark shale at the base of the Manning Canyon.

The contact between the Manning Canyon Shale and the Great Blue Limestone as it is placed here is nearly 1,300 feet higher than is shown in a diagrammatic columnar section previously prepared by the authors (Trimble and Carr, 1961, fig. 213.1). This change was made after field examination of the type localities of the Great Blue and Manning Canyon in the Oquirrh Mountains, Utah, where the upper limestone member of the Great Blue was found to be virtually identical to a limestone in the Deep Creek Mountains, Idaho, that we formerly assigned to the Manning Canyon. This limestone unit also contains, in both areas, distinctively marked black chert and dolomite found nowhere else in the stratigraphic sequence. The distinctive lithology of the limestone unit in the two areas and the similarity of the stratigraphic sequence in both areas leaves little doubt about this correlation.

Correlation with similar units in areas other than the type locality now seems more reasonable because of this placement of the contact. We previously reported (Carr and Trimble, 1961) a similarity in both lithology and thickness between units 3,4 , and 5 of the stratigraphic sequence at Dry Lake, Utah, assigned to the Brazer Limestone by Williams (1948, p. 1142), and the units then assigned by us to the Manning Canyon Shale in the Deep Creek Mountains.

It now seems more likely, on the basis of contained fossils, that units 3 and 4 of the Dry Lake section correlate with parts of the type Great Blue rather than with the Manning Canyon. In the East Tintic Mountains, Utah, Disbrow (1961) reported 850 feet of Chiulos 
Member of the Great Blue Formation, consisting largely of shale, so that the thickness of the middle shale member in the Great Blue of the Deep Creek Mountains, Idaho, no longer seems excessive. The thickness of Manning Canyon Shale, too, now accords better with other reported thicknesses, such as that of 1,100 feet given for the Manning Canyon in the Promontory Mountains, Utah (Olson, 1956), and 1,140 feet (Gilluly, 1932) and 1,559 feet (Moyle, 1959) in the Oquirrh Mountains, Utah.

More than half of the Manning Canyon in the type locality in the Oquirrh Mountains is of Pennsylvanian age. Coral and brachiopod fauna in Manning Canyon Shale in the Deep Creek Mountains, Idaho, suggest that the Mississippian-Pennsylvanian boundary is about 400 feet below the top of the Manning Canyon as determined in the Water Canyon measured section (W. J. Sando, written commun., 1964).

There are thick shale units in the Black Pine and Sublett Ranges (Youngquist and Haegele, 1955), to the southwest, that are of probable Mississippian and Pennsylvanian age and may be in part correlative with the Manning Canyon of the Deep Creek Mountains. Equivalent shale units are not known to the east in southeastern Idaho. The Manning Canyon in the Rockland and Arbon quadrangles is of Late Mississippian and Early Pennsylvanian age.

\section{PENNSYLVANIAN AND PERMIAN SYSTEMS}

\section{OQUIRRH FORMATION}

The Oquirrh Formation also was named by Gilluly (1932). The type locality is the Oquirrh Mountains, Utah. The Oquirrh is the most widespread unit in the Deep Creek Mountains and underlies most of the range. The formation is also exposed in Cedar Ridge, between the Deep Creek Mountains and the Sublett Range, and composes all the rocks of the Sublett Range within the Rockland quadrangle. The Oquirrh in the type locality is $16,000-18,000$ feet thick with no top exposed, and in other areas it is even thicker. In the Rockland-Arbon area probably less than that is present although about 6,000 feet of Oquirrh Formation has been measured in the Deep Creek Mountains, all but about 700 feet of which is Pennsylvanian in age (measured sections 6 and 7). The upper part of the section is Permian.

Four units of the Oquirrh have been mapped in the Deep Creek Mountains. It is unlikely that these units can be mapped in adjacent areas. The four units are a lower limestone (unit A), a sandy limestone (unit B), an upper limestone (unit C), and a cherty unit (unit D). Lack of time and similarity of units forced mapping of several fairly large areas as Oquirrh Formation undivided. 
The lower limestone (unit A), originally reported (Carr and Trimble, 1961) to be more than 1,000 feet thick and now known to be more than 2,000 feet thick, consists mainly of tan or light-gray to gray or blue-gray cherty limestone, silty or sandy in part, that weathers gray to tan. From a distance it resembles the Great Blue Limestone. The lower part is sandy; some quartzite occurs near the middle of the unit, and coarse-grained bioclastic limestone is common. The lower contact is placed at the top of the highest shale bed in a sequence of alternating shale and limestone assigned to the underlying Manning Canyon Shale.

The sandy limestone (unit B) is about 800 feet thick at Buck Canyon and consists mainly of light-gray to gray sandy limestone that weathers tan. Much calcareous and some noncalcareous sandstone is interbedded with the limestone. This unit generally is not cherty, although locally some beds contain a few chert nodules. The lower contact with unit $\mathrm{A}$ is mapped at the base of a persistent zone of caninid corals. Other caninid corals are found locally higher in the unit. Unit B appears to be about twice as thick on the east side of the Deep Creek Mountains as it is on the west, but it is not known whether this is due to faulting or lenslike thickening of the unit. The latter seems more likely.

The upper limestone (unit C) is nearly 2,000 feet thick. It is composed of gray to dark blue-gray limestone interbedded with silty or sandy tan-weathering limestone and minor chert-pebble conglomerate. Dark-blue-gray limestone, some of which weathers almost sooty black, characterizes the lower part of this unit. The basal contact is the base of the lowermost thick dark-blue-gray limestone. This bed is about 75 feet thick and forms a prominent and conspicuous ledge (fig. 8). Identification of the ledge is aided at many places by a coral zone in tan-weathering limestone about 35 feet above the top of the ledge. Corals collected in this zone are all of the same species, Caninia ef. C. torquia (Owen), according to determinations made by W. J. Sando (written commun., 1964).

Unit D, which constitutes the upper 1,100 feet of the Oquirrh Formation, is tan-weathering gray sandy limestone interbedded with much brownish-tan chert. Neither the top of unit D nor the top of the Oquirrh is exposed in the Rockland and Arbon quadrangles, but from reconnaissance farther south in the Deep Creek Mountains and in the Sublett Range, we estimate an additional thickness for the Oquirrh of between 5,000 and 10,000 feet in the areas to the south. Bedded chert, which characterizes unit $\mathrm{D}$, locally forms ledges more than 100 feet thick in which chert is in layers 1-8 inches thick. The base of the cherty unit is placed at the base of a thick-bedded chert immediately underlain by a limestone about 4 feet thick that contains 


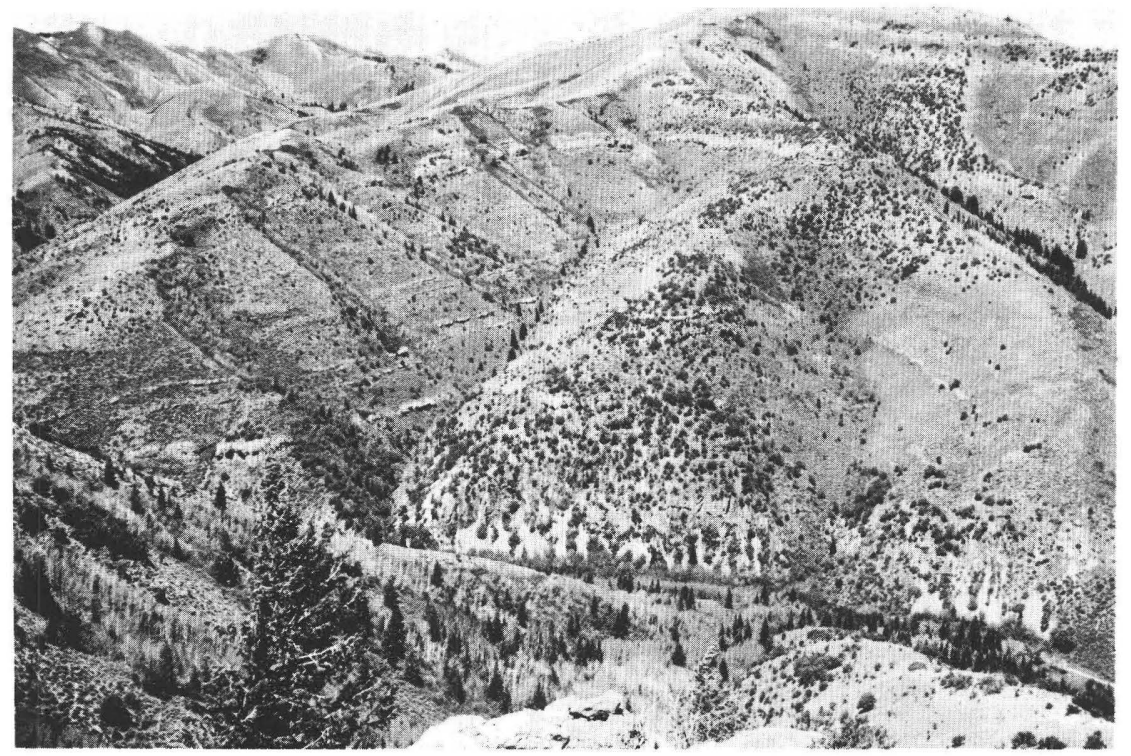

FIgURE 8.-Anticline in Oquirrh Formation north of Knox Canyon, in secs. 25 and 36, T. 10 S., R. 32 E., Arbon quadrangle. Base of unit $\mathrm{C}$ is at base of conspicuous ledge that crosses upper part of draw in central part of picture.

abundant fossil debris, mainly brachiopods. Some bedded chert locally is present below this horizon. The Pennsylvanian-Permian boundary is probably somewhat below the midpoint of this upper unit as measured north of Buck Canyon (measured section 7).

Fossils collected from the Oquirrh include fusulinids, gastropods, brachiopods, bryozoans, and corals. Fusulinids occur throughout most of the Oquirrh Formation and provide rather precise ages for most of the units, as shown in table 2. A collection from unit A about 300 feet above the base of the formation contained Fusulinella of late Atokan age. The upper part of unit B is early late Missourian and the lower part is probably Des Moinesian. Unit C is late Missourian and Virgilian. The lower part (about $400 \mathrm{ft}$ ) of unit D is Virgilian, but the upper 600-700 feet is early Wolfcampian. Fusulinids from the Oquirrh Formation in the Sublett Range in the Rockland quadrangle all indicate a Late Pennsylvanian and Early Permian age.

Fusulinids collected from the Oquirrh Formation in the Deep Creek Mountains corroborate the age range indicated by fusulinid studies in the Wasatch Range, Utah (Bissell, 1939; Baker, 1947; Thompson and others, 1950). Although genera of Morrowan age have not been collected in the Deep Creek Mountains, the lower part of unit A may be Morrowan in age. 
TABLE 2.-Distribution of foraminiferal genera in the Oquirrh Formation of the Deep Creek Mountains, Idaho

[Fusulinid and age determinations by R. C. Douglass. Stratigraphic assignments by W. J. Carr and D. E. Trimble]

\begin{tabular}{c|c|c|c|c}
\hline \multirow{2}{*}{$\begin{array}{c}\text { Age } \\
\text { assignment }\end{array}$} & & \multicolumn{2}{|c|}{ Pennsylvanian } & Permian \\
\cline { 2 - 5 } & Atokan & Des Moinesian-Missourian & Missourian-Virgilian & Virgilian-Wolfcampian \\
\hline $\begin{array}{c}\text { Stratigraphic } \\
\text { unit ........ }\end{array}$ & Unit A & Unit B & Unit C & Unit D \\
\hline $\begin{array}{c}\text { Foraminiferal } \\
\text { genera }\end{array}$ & Fusulinella & $\begin{array}{l}\text { Beedeina } \\
\text { Wedekindellina } \\
\text { Triticites }\end{array}$ & $\begin{array}{l}\text { Triticites } \\
\text { Kansanella } \\
\text { Bradyina }\end{array}$ & $\begin{array}{l}\text { Schwagerina } \\
\text { Pseudoschwagerina } \\
\text { Pseudofusulina }\end{array}$ \\
& & $\begin{array}{l}\text { Pseudofusulinella } \\
\text { Bradyina } \\
\text { Triticites } \\
\text { Bartramella }\end{array}$ \\
\hline
\end{tabular}

Thompson, Verville, and Bissell (1950, p. 430) reported that the lower 6,200 feet of the Oquirrh Formation is Pennsylvanian and the upper 9,800 feet is Permian in the southern Wasatch Range. This compares with about 5,200 feet of rocks of Pennsylvanian age and about 700 feet of rocks of Permian age in the Oquirrh Formation in the Deep Creek Mountains. Perhaps many thousands of feet of beds of Permian age have been removed by erosion.

Units A-D of the Oquirrh Formation in the Deep Creek Mountains can be correlated in time with units of the Oquirrh recognized in other areas to the south by the correspondence of the fusulinid genera. Unit A of the Oquirrh in the Deep Creek Mountains, which contains Fusulinella probably is equivalent to the Hall Canyon and Meadow Canyon Members of Bissell (1959) at the base of the formation in the southern Oquirrh Mountains, Utah, and is in part equivalent to the West Canyon Member and in part equivalent to the basal part of the sandy Oquirrh, both of Nygreen (1958), and to the West Canyon Limestone (Tooker and Roberts, 1970). Unit B of the Oquirrh in the Deep Creek Mountains contains Beedeina and Wedekindellina and is probably the same age as Bissell's Cedar Fort Member, and the upper part of Nygreen's sandy Oquirrh. Units $\mathrm{C}$ and $\mathrm{D}$ probably are equivalent to the Lewiston Peak and Pole Canyon Members of Bissell.

The gastropod Ompholotrochus, a guide to the lower part of the Lower Permian (Yochelson, 1961, p. B237) was found in the Oquirrh Formation at one locality in the Rockland quadrangle and at another locality about 7 miles south of the mapped area. In the Rockland quadrangle it was associated with the fusulinid genus Bartramella.

Youngquist and Haegele (1955) described Pennsylvanian and Permian rocks elsewhere in the Sublett Range that are about the same age as, but different in lithology from, the Oquirrh Formation in the Deep Creek Mountains. In general, the Oquirrh of the Deep 
Creek Mountains is the same age as the Wells Formation of southeastern Idaho and the Wood River Formation and parts of the Brazer Formation (C. P. Ross, 1947, 1961, 1962) in central Idaho.

\section{TERTIARY SYSTEM}

Tertiary rocks in this area, all of Pliocene age, are the Starlight Formation, the Neeley Formation, and the Walcott Tuff. These rocks are chiefly rhyolitic in composition: The Starlight is mainly bedded friable tuff and ash-flow tuff containing minor amounts of marl, sandstone, and conglomerate; the Neeley is poorly bedded friable tuff; and the Walcott is bedded friable tuff overlain by welded ash-flow tuff. In addition, the Starlight locally contains many basaltic flows and tuffs.

The Tertiary sequence partly fills Rockland and Arbon Valleys and laps onto the lower flanks of the mountains, commonly to $5,500-5,700$ feet in altitude, but locally to more than 6,000 feet. These rocks dip under the Quaternary rocks of the Snake River Plain and probably are present at depth under much of the eastern part of the Snake River Plain. Tuff similar to the Starlight is found as far northeastward as the Idaho Falls area.

\section{STARLIGHT FORMATION}

The Starlight Formation was named by Carr and Trimble (1963). The name is taken from outcrops along Starlight Creek in the Arbon quadrangle, where the lower and middle parts of the formation are fairly well exposed. The Starlight is subdivided into informal upper and lower members, separated by a middle member composed in most places of a single thick ash-flow tuff called the tuff of Arbon Valley. The upper member is mainly bedded friable rhyolitic tuff. The lower member also contains much rhyolitic tuff and locally has numerous beds of marl and basalt flows. Where the tuff of Arbon Valley is missing, the upper and lower members generally cannot be separated.

The Starlight is distributed widely in Rockland and Arbon Valleys, mainly below an altitude of about 5,700 feet and in the hilly area north of the Deep Creek Mountains. The Starlight is not exposed in the Snake River canyon except for a small area in the $\mathrm{SE}^{1 / 4} \mathrm{NE}^{1 / 4}$ sec. 6 , T. 9 S., R. 30 E., south of Massacre Rocks. The maximum thickness of the Starlight is not known, but it is at least 800 feet thick at several places.

The basal contact is generally not exposed. In the bed of Warm Springs Creek near Warm Springs, about 2 miles southwest of Rockland, tuffaceous silt, at least 25 feet thick, of the lower member 
of the Starlight overlies a conglomerate that rests directly on Paleozoic rocks.

\section{LOWER MEMBER}

The lower member of the Starlight Formation is probably about 500 feet thick. Nearly all the Starlight exposed in the Arbon quadrangle (except for the tuff of Arbon Valley) probably is part of the lower member, as is most of that exposed in the southern part of the Rockland quadrangle. In these areas the lower member consists mainly of white to gray bedded friable rhyolitic tuff and minor brown tuff and marl. North of the Deep Creek Mountains, in the area drained by Cold and Sunbeam Creeks, the lower member contains many basalt flows underlain by much basaltic tuff and breccia.

In most places the basalt flows appear to be part of a conformable sequence, but locally, along upper West Fork Sunbeam Creek, porphyritic basalt of the lower member is overlain with angular discordance by younger basalts and tuffs of the lower member of the Starlight. In the northwestern part of the Arbon quadrangle, basaltic tuff and breccia form most of the lower member over a wide area.

The basalt flows north and northeast of the Deep Creek Mountains have an area of distribution similar to, but somewhat wider than, the tuff. The lower member south and southeast of Mollys Nipple also contains some basalt. Few if any occurrences of basalt can be assigned with complete certainty to the upper member, but basalt flows of the Starlight in the gorge of Rock Creek north of Table Mountain may be part of the upper member.

The basalt is well exposed locally in many places, but the best outcrops are along the north side of Cold Creek. There, porphyritic columnar basalt about 100 feet thick rests on Paleozoic rocks or is locally separated from them by $10-20$ feet of massive fine-grained rhyolitic tuff. The porphyritic basalt is overlain by about $\mathbf{1 7 5}$ feet of basalt that weathers reddish brown and is characterized by a spotted tapiocalike weathered surface. The basalt in the lower 125 feet of this unit is dense and in the upper $\mathbf{5 0}$ feet is fine grained and platy. Both the dense and platy basalt probably are part of the same flow.

Porphyritic basalt and platy basalt are distinctive types recognized at other localities, but the peculiar tapiocalike surface so conspicuous on some of the Cold Creek flows has not been seen elsewhere.

Another porphyritic flow is interbedded with basaltic tuff and breccia north of Starlight Creek in the Arbon quadrangle. A similar basalt apparently is stratigraphically below or within basaltic tuff in the lower member of the Starlight near the mouth of Bowen Canyon in the $\mathrm{SW}^{1 / 4}$ sec. 36, T. 8 S., R. $31 \mathrm{E}$. 
The sequence and distribution of rock types indicate that the eruptive center or complex of centers that produced the basaltic rock began violently by erupting breccia and tuff, and later became more quiet and erupted primarily basalt flows. Locally, as in the Sunbeam Creek area, basalt flows are interstratified with rhyolitic tuff erupted from adjacent source vents. The proportion of rhyolitic material increases southeastward in the Arbon quadrangle. South of Starlight Creek the basaltic tuff is only a few feet thick.

In the valley of Starlight Creek and at other places the lower part of the lower member contains many beds of marl and a few beds of conglomerate. The marl locally contains mollusk shells, some of which are silicified.

Two samples of marl from the east slope of Mollys Nipple contained 55-95 percent calcite; the purer marl contained only a little clay in fine layers and a few very small fragments $(<0.05 \mathrm{~mm})$ of quartz and feldspar. Traces of diatoms, shells, and plant remains were present. The other marl, less well indurated, contained about 30 percent rhyolitic shards from $0.3-1 \mathrm{~mm}$ long, 8-percent small crystal fragments mainly of sanidine, but a few of quartz, plagioclase, oxyhornblende, and augite, and 7-percent lithic fragments of pumice.

\section{MIDDLE MEMBER}

The middle member of the Starlight Formation consists of ash-flow tuffs and minor bedded air-fall tuff. The principal unit is the tuff of Arbon Valley; at many places it makes up the entire middle member. The tuff of Arbon Valley and associated rocks are exposed locally in the vicinity of Mollys Nipple, in the southern part of the Rockland quadrangle, and in a large area north of the Deep Creek Mountains in the Rockland and Arbon quadrangles. The tuff of Arbon Valley also crops out at several localities south of Starlight Creek and in the Sawmill and Squaw Creek tributaries of Moonshine Creek in the Arbon quadrangle. Several occurences are east of Bannock Creek in a band extending from the north edge of the area to the outcrops southeast of Pauline. The tuff of Arbon Valley has been identified as far south as Cedarhill (fig. 1), 15 miles south of the Rockland quadrangle, and in the southwestern part of the Paradise Valley quadrangle, about 60 miles northeast of the Arbon quadrangle, but it is not known west of the Sublett Range. The widely separated occurrences are similar petrographically and probably are parts of the same sequence of ash-flow tuffs. The tuff of Arbon Valley is as much as $\mathbf{1 0 0}$ feet thick but in most places is much thinner.

The tuff of Arbon Valley is light gray to tan, poorly to well indurated, and rhyolitic. In its upper part it commonly contains 
about 30 percent of broken and embayed, but generally conspicuous, crystals, mostly of euhedral quartz and sanidine, and some biotite, as well as a few lithic or pumice fragments. The matrix is fine grained, mostly devitrified dense ash without conspicuous pyroclastic texture. Pyroclastic texture is more apparent near the base of the unit than the top. Locally, the tuff contains a thin glassy welded zone. The lower part of the tuff is nonwelded, friable, and pumiceous. At Mollys Nipple, it is separated from tuff and marl of the lower member of the Starlight Formation by a layer of gravel (fig. 9) that is considered to be part of the lower member.

The tuff of Arbon Valley at Mollys Nipple, and at most other places where it is well exposed, appears to consist of a sequence of ash-flow tuffs. In a small tributary of Blind Spring Creek near the west edge of the Michaud quadrangle, less than 2 miles north of the Arbon quadrangle, the unit contains two ash-flow tuff units separated by 8-10 inches of quartz crystals and biotite in a matrix of shards. This crystal-rich concentrate is bedded and contains a few exotic pebbles of basalt. The lower contact of the concentrate is cemented or welded to an underlying dense jointed ash-flow tuff. The hard underlying tuff is about 25 feet thick and grades downward into an estimated 50 feet of massive pumiceous rhyolitic tuff that is virtually lacking in quartz crystals and that appears to conformably overlie bedded rhyolitic tuff of the lower member of the Starlight Formation. Overlying the bedded crystal-rich concentrate is ash-flow tuff that is light gray and glassy in the lower 3 feet. For at least 7 feet above the glassy tuff, the rock appears progressively coarser grained upward and richer in crystals. Probably both the overlying and underlying ash-flow units and the crystal-rich concentrate cooled together as a single cooling unit.

The best exposures for interpreting the origin of the tuff of Arbon Valley are in the $\mathrm{SE}^{1 / 4}$ sec. 26 , T. 7 S., R. 32 E., in the Michaud quadrangle. The following gradational sequence of beds is exposed: A basal white massive nonwelded pumiceous tuff nearly lacking in crystals; overlain by brown pumiceous nonwelded tuff; densely welded brown glassy tuff only a few feet thick that contains about 20-30 percent crystals of quartz, sanidine, and biotite, and dark deformed pumice fragments; and devitrified jointed crystal-rich partially welded tuff. Across a small valley to the east is a phase still higher in the sequence that contains more abundant crystals, probably accounting for more than 50 percent of the rock. This phase also contains vapor phase minerals in small cavities.

This multiple ash-flow sequence may be either a single compound cooling unit or two or more separate cooling units. Exposures are not sufficient for understanding the exact cooling history of the tuff of 


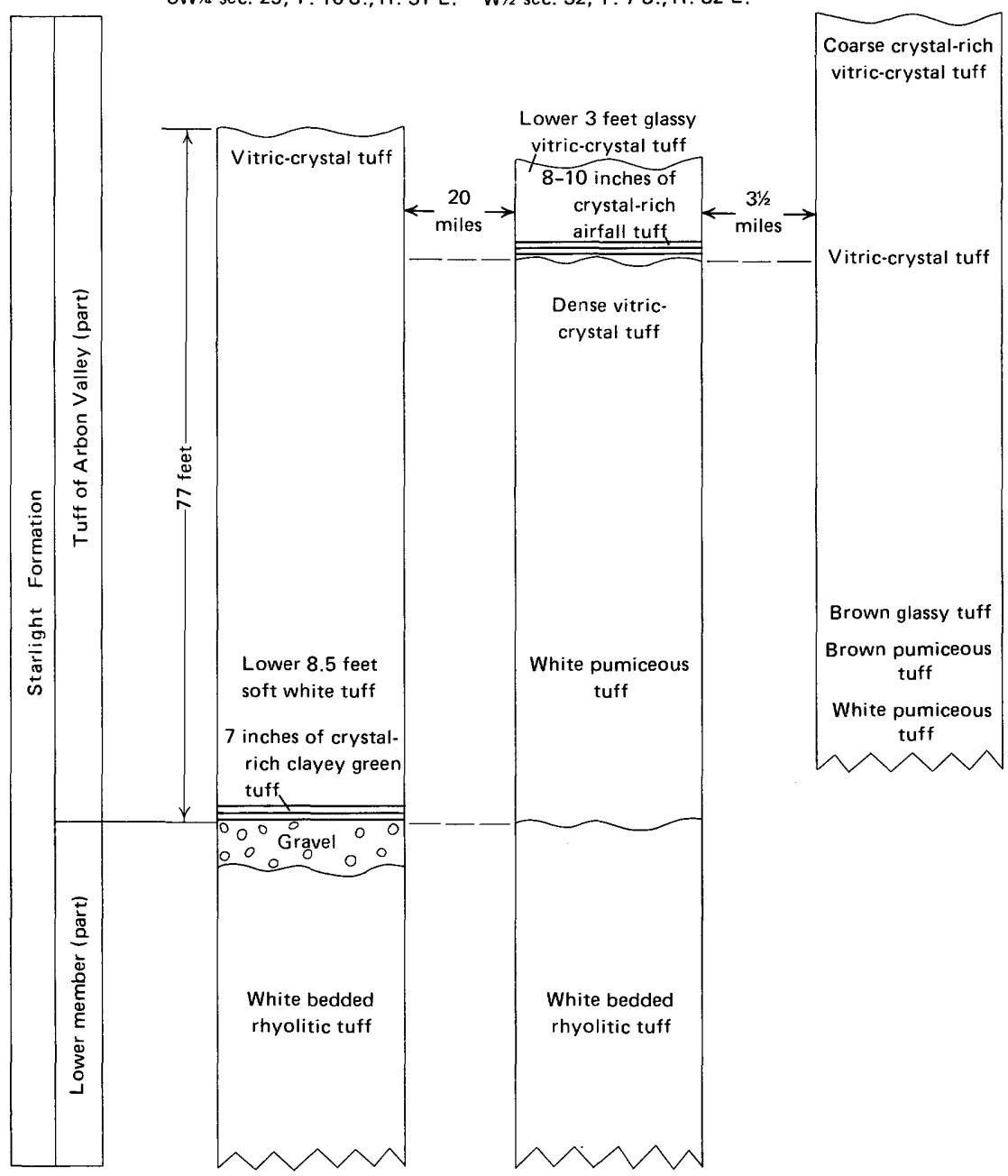

FiguRE 9.-Partial sections of the tuff of Arbon Valley.

Arbon Valley. The lack of crystals in the.lower parts of the unit and the extreme abundance of crystals in the upper parts suggest that the cooling unit consists of several thin ash flows, each successively richer in crystals. These ash flows probably were erupted in rapid succession from a magma chamber with progressive lowering of temperature, or from a chamber containing layered magma in which crystals had settled. Probably, the initial eruption temperature was lower than that of most ash-flow tuffs, but it was sufficiently high for the tuff to weld itself at least locally after it came to rest. The temperature was too low, however, for most of the deposit to weld. 
Partial welding, represented by the upper crystal-rich phases, is the maximum effect.

The lower cooling unit at Blind Spring (fig. 9), which probably correlates in part with the cooling unit in sec. 26 , lacks the crystalrich, partially welded phases. This suggests that deposition of the thin air-fall tuff interrupted the successive accumulation of ash-flow tuffs at Blind Spring.

A dark obsidian welded tuff appears to overlie the tuff of Arbon Valley at several places in secs. 10 and 11, T. 8 S., R. 32 E., in the Arbon quadrangle. Similar rock is found as float at several places in the drainage area of Sunbeam Creek in the Rockland quadrangle. The contact between a cooling unit containing the glassy welded tuff and the cooling unit that includes the vitric-crystal tuff of Arbon Valley was trenched at a locality at the section line along the west edge of the $\mathrm{NW}^{1 / 4}$ sec. 11 . There the vitric-crystal tuff is unconformably overlain by about 18 inches of gray, tan, and nearly white nonwelded rhyolitic tuff that is stratified in the lower 6-8 inches and nonstratified and coarser in the upper part. This tuff, which probably is an air-fall tuff, contains only a few quartz crystals. This is overlain by ash-flow tuff that is brown and unwelded at the base, becomes welded and glassy about 2 feet above the base, and becomes increasingly welded upward into black perlitic obsidian welded tuff about 4 feet above the base. The obsidian welded tuff is about 8 feet thick at this locality.

The upper part of the ash-flow tuff is not exposed here, but similar tuff is exposed at two localities in the Michaud quadrangle to the north, one at the junction of the canyon of Blind Spring Creek with a tributary in the SW $1 / 4$ sec. $29, \mathrm{~T} .7 \mathrm{~S}$., R. $32 \mathrm{E}$., and the other in a ravine in the $\mathrm{SW}^{1 / 4}$ sec. $21, \mathrm{~T}$. $7 \mathrm{~S}$., $\mathrm{R}$. $32 \mathrm{E}$. At the latter locality the lowest part of the exposure is perlitic obsidian tuff that contains large spherulites, some as much as 8 inches in diameter. The perlitic obsidian welded tuff is more than 25 feet thick and grades upward into brown welded tuff that becomes lighter in color and less welded upward and grades into tan pumiceous tuff containing some sanidine crystals.

Similar tuffs occur elsewhere above the tuff of Arbon Valley and probably are local ash-flow deposits, all of about the same age and derived from the same magma. They probably are not physically connected. All these ash-flow tuff deposits, although unconformable on the tuff of Arbon Valley, probably are about the same age and chemical composition as the tuff of Arbon Valley, and for this reason they are mapped together.

The tuff of Arbon Valley is younger than most of the basalt of the Starlight Formation in the area of this report, and in most places it 
disconformably overlies an irregular surface cut on the basalt and older rocks. The tuff of Arbon Valley directly overlies basalt in a wide area of the drainage basins of Cold Creek and Sunbeam Creek, but locally it rests directly on basaltic tuff, as on upper Starlight Creek.

UPPER MEMEBER

The upper member of the Starlight Formation can be recognized with confidence in only a few areas where it is known to overlie the tuff of Arbon Valley, such as east of Rock Creek, in the southern part of the Rockland quadrangle, or where it closely underlies the Neeley or the Little Creek Formation, such as in the northern or western part of the Rockland quadrangle. In sec. 24 , T. 9 S., R. $30 \mathrm{E}$., the upper member is fairly well exposed in roadcuts and on the hillside below a pinchout of the Neeley and Walcott Formations. The upper member can also be recognized where conglomerate interlensed with the tuff or tuffaceous sediments contains pebbles of the tuff of Arbon Valley, as does conglomerate in a gravel pit in the $\mathrm{SE}^{1 / 4} \mathrm{SW}^{1 / 4}$ sec. 14 , T. 10 S., R. 30 E. The upper member probably is more than 200 feet thick.

Most of the upper member consists of white parallel-bedded friable rhyolitic tuff, but it also contains massive pumiceous tuff, breccia, and marl. In Rockland Valley conglomerate lenses locally form an important part of the upper member. Most of the conglomerate is crossbedded and is only moderately indurated. The constituent pebbles and cobbles consist almost entirely of rocks of Paleozoic age, mostly chert and quartzite and, rarely, well-rounded weathered pebbles of the tuff of Arbon Valley. The matrix is sand and clay, and locally contains some reworked tuff.

SOURCE VENTS

Three probable source vents of the Starlight Formation are known in the Rockland quadrangle: (1) one in the $\mathrm{NW}^{1 / 4} \mathrm{SE}^{1 / 4}$ sec. 35 , T. 9 S., R. 30 E., which is only a few hundred feet south of the intrusive vitrophyre northwest of Rockland; (2) on the west side of Table Mountain in the $\mathrm{SE}^{1 / 4} \mathrm{SW}^{1 / 4}$ sec. 31 , T. 9 S., R. 30 E.; and (3) about 1.5 miles southeast of Rockland in the $\mathrm{SE}^{1 / 4} \mathrm{SW}^{1 / 4} \mathrm{sec} .9, \mathrm{~T} .10$ S., R. $31 \mathrm{E}$. The rocks of these vents all are massive rhyolitic tuff and breccia that incorporate a number of angular blocks of basalt, as much as 2 feet across at the locality northwest of Rockland and as much as 8-10 inches across on the west side of Table Mountains.

In the Arbon quadrangle a rhyolitic breccia dike in the $E^{1 / 2}$ sec. 26, T. 8 S., R. 32 E., cuts beds of the lower member of the Starlight and probably represents a fissure source for some part of the formation. 
The source vent for the basaltic flows and pyroclastic rocks in the Starlight probably was in the area of the basaltic breccia west of Bannock Creek in the Arbon quadrangle and in the adjoining Michaud quadrangle.

\section{INTRUSIVE ROCKS IN THE STARLIGHT FORMATION}

Vitrophyre and silicic porphyry occur as intrusive bodies in the Starlight Formation. The vitrophyre is found at several localities in the Rockland quadrangle and in the adjoining American Falls quadrangle (Carr and Trimble, 1963). The silicic porphyry crops out in large dikes in the Arbon and adjoining Michaud quadrangles.

The vitrophyre is exposed at three localities in the Rockland quadrangle. The most imposing outcrop of the vitrophyre is a plug or partly collapsed volcanic neck about 200 feet in diameter in the $\mathrm{NW}^{1 / 4} \mathrm{SE}^{1 / 4}$ sec. 35 , T. $9 \mathrm{~S}$., R. $30 \mathrm{E}$., 2.3 miles northwest of Rockland. The other outcrops are on the east and west sides of Table Mountain, one in the $\mathrm{SE}^{1 / 4} \mathrm{NE}^{1 / 4}$ sec. 20 , T. 9 S., R. 30 E., and the other in the $\mathrm{NE}^{1 / 4} \mathrm{NW}^{1 / 4}$ sec. 29 , T. $9 \mathrm{~S}$., R. $30 \mathrm{E}$.

The vitrophyre normally is a black perlitic glass with abundant white feldspar phenocrysts. Locally, as in the plug northwest of Rockland, it is spherulitic. There are many variations in color and texture, however.

Intrusion of the vitrophyre northwest of Rockland is shown by the steeply dipping flow structure, indicating high-angle contacts in the plug. Sagging of the flow structure at the top of the plug suggests collapse after intrusion.

Contemporaneity of at least part of the vitrophyre with the upper part of the upper member of the Starlight is indicated by incorporation of large angular blocks of vitrophyre in tuff beds of the upper member of the Starlight in sec. 4, T. 8 S., R. 31 E., in upper Ferry Hollow in the adjoining American Falls quadrangle (Carr and Trimble, 1963). The blocks probably were emplaced by explosions at a vent. The vitrophyre in nearby outcrops is a flow breccia of black porphyritic obsidian that locally is incorporated in white tuff.

A large dike of silicic porphyry intrudes beds of the lower member of the Starlight in sec. 12, T. 8 S., R. 32 E., and sec. 18, T. 8 S., R. 33 $\mathrm{E}$. , in the Arbon quadrangle. Another similar intrusive body is in sec. 24, T. 7 S., R. 32 E., in the Michaud quadrangle. The porphyry dike in the Arbon quadrangle is jointed in columns that mostly are perpendicular to the walls of the dike but locally, especially at the south end of the dike, are randomly oriented. Some of the porphyry at the south end of the dike may represent short flows.

\section{AGE AND CORRELATION}

Fossils from both the upper and lower members of the Starlight Formation indicate an early or middle Pliocene age. Mollusks are 
abundant in both members, particularly in marl beds, and a few vertebrate fossils have been found in conglomerate of the upper member. Diatoms are common locally throughout the upper and lower members.

Mollusks, as identified by D. W. Taylor, are given in table 3. Concerning the collections listed in table 3, Taylor (written commun., 1960) stated:

The mollusks from the Starlight Formation are considered of middle Pliocene age because of similarities to those in three independently dated assemblages in southern Idaho, and because of marked differences from other mollusks in southeastern Idaho. The three other units in which similar mollusks occur are the Teewinot Fromation [defined by Love, 1956] of Jackson Hole, Wyo., and Grand Valley and Star Valley, Wyo.-Idaho; the Banbury Formation in south-central Idaho; and the Salt Lake Formation in the Goose Creek area [fig. 1], 70 miles southwest of American Falls. Mollusks from the Teewinot and Banbury are associated with middle Pliocene mammals; those from Goose Creek were stratigraphically higher than mammals of early or middle Pliocene age.

The assignment of a late middle Pliocene age [Mapel and Hail, 1959, p. 236] to the mollusks of the Salt Lake Formation is overly precise and may be wrong. On present evidence the age is well established as middle Pliocene, but probably not from the latest part of this interval.

Taylor also studied some earlier collections made by $\mathrm{W}$. C. Mendenhall, G. R. Mansfield (1920, p. 54), and P. V. Roundy. All these fossils are from beds mapped as Salt Lake Formation or from similar rocks in southeastern Idaho, and all have a few mollusks in common with those listed in table 3 for the Starlight Formation. Little or no stratigraphic information is available for these localities, however.

In this region only one locality has yielded Tertiary vertebrate fossils. Two camel bones and a horse tooth were recovered from the Starlight Formation by D. W. Taylor and us from a pit in gravel interbedded with rhyolitic tuff in the $\mathrm{SW}^{1 / 4}$ sec. $28, \mathrm{~T} .11 \mathrm{~S} ., \mathrm{R} .31$ E., about 10 miles south of Rockland. The gravel contains pebbles of the tuff of Arbon Valley and is, therefore, in the upper member of the Starlight. G. E. Lewis (written commun., 1973) reported on these fossils as follows: "Antero-external fragment of upper molar of an advanced species of ?Hipparion; two fragmentary metacarpals of a giant camel ?Megatylopus sp., probably of middle Pliocene age." A mastodon jaw recovered from this same pit was tentatively identified at Idaho State University as Pliomastodon (M. L. Hopkins, written commun., 1958).

We examined Tertiary rocks mapped by Mansfield (1952) as Salt Lake Formation, basalt, and rhyolitic rocks in the Ammon and Paradise Valley quadrangles (fig. 1), 70 miles northeast of the report area. Some of these rocks are strikingly similar to the Starlight Formation of the Rockland and Arbon quadrangles and to the overlying Walcott Tuff and Neeley Formation. White bedded friable 
TABLE 3.-Distribution of mollusks in the Starlight Formation in the Rockland and Arbon quadrangles, Power County, Idaho

\begin{tabular}{|c|c|c|c|c|}
\hline & \multicolumn{3}{|c|}{$\begin{array}{l}\text { Lower member } \\
\text { (by locality No.) }\end{array}$} & \multirow{2}{*}{$\begin{array}{c}\begin{array}{c}\text { Upper member } \\
\text { (by locality No.) }\end{array} \\
21673\end{array}$} \\
\hline & 21669 & 21670 & 21671 & \\
\hline \multicolumn{5}{|l|}{ Freshwater clams: } \\
\hline Sphaerium sp. a & $x$ & ... & $x$ & $x$ \\
\hline Sphaerium sp. b & $\hat{\ldots .}$ & $\ldots$ & $\ldots$ & $x$ \\
\hline Pisidium spp. . . & $\ldots$ & $\ldots$ & $\ldots$ & $x$ \\
\hline \multicolumn{5}{|l|}{ Freshwater snails: } \\
\hline $\begin{array}{l}\text { Valvata humeralis (Say) } \\
\text { Hudrobiidae indet. }\end{array}$ & $\ldots$ & $\ldots$ & $x$ & $?$ \\
\hline $\begin{array}{l}\text { Hydrobiidae, indet. . . . } \\
\text { Stagnicola, n. sp. . . . . }\end{array}$ & $x$ & $\cdots$ & $x$ & $\cdots$ \\
\hline $\begin{array}{l}\text { Stagnicola, n. sp. } \\
\text { Stagnicola albiconica (Taylor) }\end{array}$ & $\cdots$ & $\begin{array}{l}\times \\
\ldots\end{array}$ & $\begin{array}{l}\cdots \\
\cdots\end{array}$ & $\cdots$ \\
\hline Stagnicola sp. $\ldots \ldots \ldots \ldots \ldots$ & $\begin{array}{c}\times \\
\ldots \\
\ldots\end{array}$ & $\cdots$ & $\ldots$ & 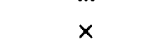 \\
\hline Fossaria dalli (Baker). & $\ldots$ & ... & $x$ & $\ldots$ \\
\hline Bulimnea sp. ....... & $\ldots$ & $\ldots$ & $\hat{x}$ & $x$ \\
\hline Planorbarius, n. sp. a. & $x$ & ... & $x$ & $x$ \\
\hline Planorbarius, n.sp. b ..... & $\cdots$ & $\cdots$ & $x$ & $\cdots$ \\
\hline $\begin{array}{l}\text { Promenetus umbilicatellus } \\
\text { (Cockerell) ... }\end{array}$ & $\ldots$ & $\ldots$ & $x$ & $?$ \\
\hline Planorbidae, genus uncertain. . & $\cdots$ & $x$ & $\hat{\ldots}$ & $\therefore$ \\
\hline Ferrissia sp. . & ... & $\ldots$ & $\ldots$ & $x$ \\
\hline Physa, n. sp. $\ldots \ldots \ldots \ldots$ & $\ldots$ & ... & $x$ & $\ldots$ \\
\hline Physa sp...... & ... & $\cdots$ & $\cdots$ & $x$ \\
\hline \multicolumn{5}{|l|}{ Land snails: } \\
\hline Gastrocopta (Albinula), n. sp. & ... & ... & $x$ & $\cdots$ \\
\hline Vertigo spp. $\ldots \ldots \ldots \ldots \ldots$ & $\ldots$ & $\ldots$ & $x$ & ... \\
\hline Vallonia, n. sp. . . . . . . & $\cdots$ & ... & $x$ & $\cdots$ \\
\hline cf. Succinea & .. & $\ldots$ & $x$ & ... \\
\hline Bulimulus, n. sp. a . & $\cdots$ & $\ldots$ & $x$ & $\cdots$ \\
\hline Bulimulus, n. sp. b. . & $\ldots$ & $\cdots$ & $x$ & $\cdots$ \\
\hline Oreohelix sp.. & ... & ... & $x$ & $\cdots$ \\
\hline
\end{tabular}

DESCRIPTION OF LOCALITIES

21669. - SE $1 / 4$ sec. 29 , T. 10 S., R. 31 E.; marl beds, lower east side of Mollys Nipple. $21670 .-N^{1 / 4} S^{1 / 4}$ sec. 18 , T. 8 S., R. 33 E.

21671. - NE $1 / 4 \mathrm{NW}^{1 / 4}$ sec. 31, T. 8 S., R. $33 \mathrm{E}$.; small hill of silicified marl?) in type locality of Starlight Formation.

21673. $-S^{1 / 4}$ sec. 24, T. 9 S., R. 30 E.; east of Rock Creek.

rhyolitic tuff, a major constituent of the Starlight, is found in both areas, and a crystal-rich tuff very similar to the tuff of Arbon Valley was found interbedded with basalt along the road in the $S 1 / 2$ sec. 16, T. 4 S., R. 39 E., Paradise Valley quadrangle.

Mansfield $(1952$, p. 46,59$)$ concluded that the welded tuffs and bedded tuffs in the Ammon quadrangle are Pleistocene on the basis of a few plant fossils found below them. We examined this plant fossil locality and concluded that either the fossil beds are a young valley fill or the state of preservation alone led to their identification as Pleistocene; thus, the conclusion that the nearby welded tuffs are Pleistocene seems unwarranted.

The sequence of volcanic rocks in the Ammon area extends at least as far northeast as Willow Creek, northeast of Idaho Falls (fig. 1). Earlier, Mansfield (1927, p. 112) noted that, "Rhyolites occur 
westward along the northern parts of the ranges from the Yellowstone National Park to the region here described (southeastern Idaho), and to the Fort Hall Indian Reservation. The rhyolite is probably not absolutely continuous, but the occurrences are so numerous and the character of the rock so similar that there seems little reasonable doubt that the rhyolites in this region and in the Yellowstone National Park are essentially of the same geologic age." He further stated that, "In the Fort Hall Indian Reservation *** the rhyolite and the Salt Lake Formation are interbedded here and there and are associated with beds of volcanic ash." It is clear to us that some of the rhyolite to which Mansfield referred is the tuff of Arbon Valley.

To the west the Starlight is correlated, on the basis of molluscan faunas, with at least the lower part of the Salt Lake Formation of the Goose Creek district and with the Banbury Formation of the western Snake River Plain. West of the Rockland quadrangle in eastern Cassia County the Starlight Formation probably correlates with at least part of the rocks that Anderson (1931, p. 37-44) mapped as Payette or Salt Lake Formation. Latitic welded tuff that overlies these beds does not crop out east of the Sublett Range and the tuff of Arbon Valley has not been found west of the Sublett Range; therefore, exact correlation cannot be made at present. However, the rocks dated as middle or lower Pliocene and mapped as the lower part of the Salt Lake Formation by Mapel and Hail (1959) in the Goose Creek area underlie a series of latite flows and welded tuffs that are probably of the same age as welded tuffs overlying the Payette or Salt Lake Formation as mapped by Anderson in eastern Cassia County.

In summary, the Starlight Formation is early or middle Pliocene in age, or both, with present evidence favoring middle Pliocene. It correlates with part of what has been mapped as Salt Lake Formation in southeastern Idaho, and, on the basis of mollusks, is closely related to the Teewinot Formation of the Jackson Hole region. Rocks referable to the Starlight may extend northeastward to the general area of Idaho Falls.

\section{GRAVEL AND CONGLOMERATE}

Gravel and conglomerate overlie tuff of the lower member of the Starlight in a large area along the east edge of the Arbon quadrangle between Pauline and Rattlesnake Creek. The conglomerate is best exposed in the pit just northwest of Pauline; at most places it does not crop out or is poorly exposed. Where it does not crop out, it weathers to an extensive litter of pebbly gravel in the soil.

The gravel is composed mainly of rounded pebbles of Paleozoic rock and in many places is cemented by calcite into a conglomerate. 
The conglomerate is tilted as much as $40^{\circ}$ in the pit near Pauline, whereas dips observed in the tuff in this general locality do not exceed $20^{\circ}$. This discordance in dip and the distribution of the gravel around "islands" of tuff in both the lower member and the tuff of Arbon Valley of the Starlight Formation may indicate an unconformity between the gravel and the tuff but could be the result of higher initial dip in the gravel and irregular deposition. Beds younger than Tertiary are not known to be tilted nearly as much as the gravel, and the gravel, therefore, is presumed to be part of the Starlight Formation and Pliocene in age, although it could be somewhat younger.

\section{NEELEY FORMATION}

The Neeley Formation consists mostly of tan to orange tuffaceous clayey sandstone and rhyolitic tuff that overlies the Starlight Formation and underlies the Walcott Tuff. The formation, originally named the Neeley Lake Beds by Stearns, Crandall, and Steward (1938, p. 43), was redesignated Neeley Formation by Carr and Trimble (1963, p. G15). The type locality for the Neeley is along the Snake River downstream from American Falls, just north of the boundary of the Rockland quadrangle. The formation is exposed in several places along the Snake River to within less than a mile of the west edge of the report area. The Neeley and the overlying Walcott Tuff are exposed on the north side of the Snake River in the $\mathrm{SE}^{1 / 4} \mathrm{NE}^{1 / 4}$ sec. $31, \mathrm{~T} .8 \mathrm{~S}$., R. $30 \mathrm{E}$., and south of the river, about half a mile southeast of Massacre Rocks, in the $\mathrm{SE}^{1 / 4} \mathrm{NE}^{1 / 4}$ sec. $6, \mathrm{~T}$. $9 \mathrm{~S} ., \mathrm{R} .30 \mathrm{E}$. The Neeley is also exposed east of a graben in tributaries of Cold Creek in secs. 20 and 29, T. 8 S., R. 31 E., and north and south or Rock Creek in secs. 9 and 16, T. 9 S., R. 30 E. The formation, along with the overlying Walcott Tuff, pinches out in the $\mathrm{SW}^{1 / 4} \mathrm{NW}^{1 / 4}$ sec. 24 , T. $9 \mathrm{~S}$., R. $30 \mathrm{E}$., on the east side of the valley of Rock Creek. Outside the report area it may extend as far northeast as the Idaho Falls region. The Neeley is at least 100 feet thick at its locality in the adjoining American Falls quadrangle, but near Massacre Rocks it is about $\mathbf{4 0}$ feet thick, north of Rock Creek it is only about 30 feet thick, and it thins from 16 feet to less than 7 feet in thickness in about a quarter of a mile near the pinchout east of Rock Creek.

Lithologically, the Neeley Formation differs little from place to place. The lower part tends to be coarser grained than the upper part and contains as much as 50 percent or more of nonvolcanic debris. A layer of gravel several feet thick is at the base. The upper 5-10 feet of the Neeley is nearly everywhere tan fine-grained massive friable tuff. Bedding, sorting, and consolidation are poor throughout the formation, and the color is typically orange to tan. 
Minor features include small manganese and calcite nodules and local pinhole weathering.

A minor but important unit of the Neeley is exposed near a viewpoint on the south side of the Snake River (fig. 10) in the SE. cor. sec. 29 and the SW. cor. sec. 28 , T. 8 S., R. 30 E. Here, just about river level, 5-10 feet of white to tan well-indurated fossiliferous marl is exposed. The marl is more than 60-percent $\mathrm{CaCO}_{3}$ and consists of very fine grained calcite and clay with poorly preserved mollusk shells and some diatoms. No shards were noted, but the marl contains about 5-percent quartz and feldspar, as small angular grains. A similar marl bed in the Neeley is exposed at two other localities along the Snake River, one in the $\mathrm{SE}^{1 / 4} \mathrm{NE}^{1 / 4} \mathrm{sec}$. 31, T. 8 S., R. 30 E., and the other directly across the river from Eagle Rock.

The gravel at the base of the Neeley is exposed at two localities in the Rockland quadrangle-at the locality southeast of Massacre Rocks and near the pinchout east of Rock Creek. Gravel is also present in the basal part of the Neeley in sec. 4 , T. 8 S., R. 31 E., where it overlies the Starlight Formation in upper Ferry Hollow, in the American Falls quadrangle (Carr and Trimble, 1963). The gravel at the base of the unit near the pinchout is 6.5 feet thick and consists mainly of well-rounded sandstone and chert pebbles in a matrix of sand.

The lower contact of the Neeley is the base of the gravel, which locally rests on the underlying tuff of the Starlight with slight angular unconformity.

Stearns (Stearns and others, 1938, p. 43) regarded the Neeley as early Pliocene(?) in age, but he found no fossils. A collection of mollusks from the marl in the $\mathrm{SW}^{1 / 4}$ sec. 28 , T. $8 \mathrm{~S}$., R. $30 \mathrm{E}$., was examined by D. W. Taylor, who reported (written commun., 1959) the following:

Freshwater clams:

Sphaerium sp. a

Pisidium spp.

Freshwater snails:

Valvata humeralis (Say)

Lithoglyphus, n. sp.?

Stagnicola albiconica (Taylor)

Bulimnea sp.

Planorbarius, n. sp. a

Promenetus umbilicatellus (Cockerell)

Physa sp.

Land snail:

Indeterminate gastropod

Taylor concluded that (written commun., 1960) "this assemblage is not significantly different from that of the Starlight Formation, and its faunal correlatives are the same as those previously discussed for the Starlight." Thus, the Neeley Formation probably is middle 
Pliocene in age, and the unconformity at the base of the Neeley represents a hiatus of short duration.

Gravel and marl at the base of the formation, the abundance of nonvolcanic debris in most of the tuff, and freshwater sponge spicules reported in the tuff by Stearns and Isotoff $(1956$, p. 32) all indicate that the most of the Neeley Formation was deposited in water.

\section{WALCOTT TUFF}

The Walcott Tuff was named by Stearns and Isotoff (1956, p. 23) from Lake Walcott, an impounded segment of the Snake River mostly downstream from this area. Stearns, Crandall, and Steward (1938, p. 44) originally named obsidian welded tuff and bedded tuff of the Walcott the Eagle Rock Tuff. The name Eagle Rock Tuff was abandoned in favor of Walcott Tuff by Carr and Trimble (1963, p. G16), who followed the usage of Stearns and Isotoff. The Walcott is exposed in the same general area as the Neeley Formation; however, it is more extensive. It crops out at many places along the Snake River, and in the northern part of the Rockland quadrangle south of the Snake River. Together with the Neeley, it occurs north and south of Rock Creek. It pinches out southward, east of Rock Creek. The Walcott Tuff in the bluff visible from a viewpoint south of the Snake River (fig. 10) in secs. 28 and 29, T. 8 S., R. 30 E., is 23 feet thick, but a quarter of a mile farther upriver in the same bluff the Walcott is 50-75 feet thick. The Walcott east of Rock Creek near the pinchout is 20-25 feet thick.

The Walcott Tuff consists of two distinctive rhyolitic members (not mapped separately) - a lower bedded tuff member and an upper obsidian welded or ash-flow tuff member (fig. 11). The lower bedded tuff member is composed of white to light-gray parallel-bedded rhyolitic ash and is very similar in appearance to some of the bedded tuff of the Starlight Formation. The tuff is medium to fine grained and consists almost entirely of clear shards and a very few feldspar and pyroxene crystals. Some beds in the lower 4 feet contain ash pellets as much as $2 \mathrm{~mm}$ across. The tuff is friable, but it varies in duration. The bedding is remarkably uniform but locally is slightly distorted at the contact with the overlying welded tuff member (fig. 12). The uppermost 6 inches to 1 foot is locally fused by the overlying ash-flow tuff. The thickness of the bedded tuff member is 7-12 feet.

The upper obsidian welded or ash-flow tuff member, slightly to densely welded throughout, is more than $\mathbf{5 0}$ feet thick locally but is generally only about 15 feet thick. It consists largely of black dense perlitic spherulitic obsidian welded tuff. The central part in the thicker sections is commonly devitrified and contains abundant spherulites. Lithophysae are common only at places where the 


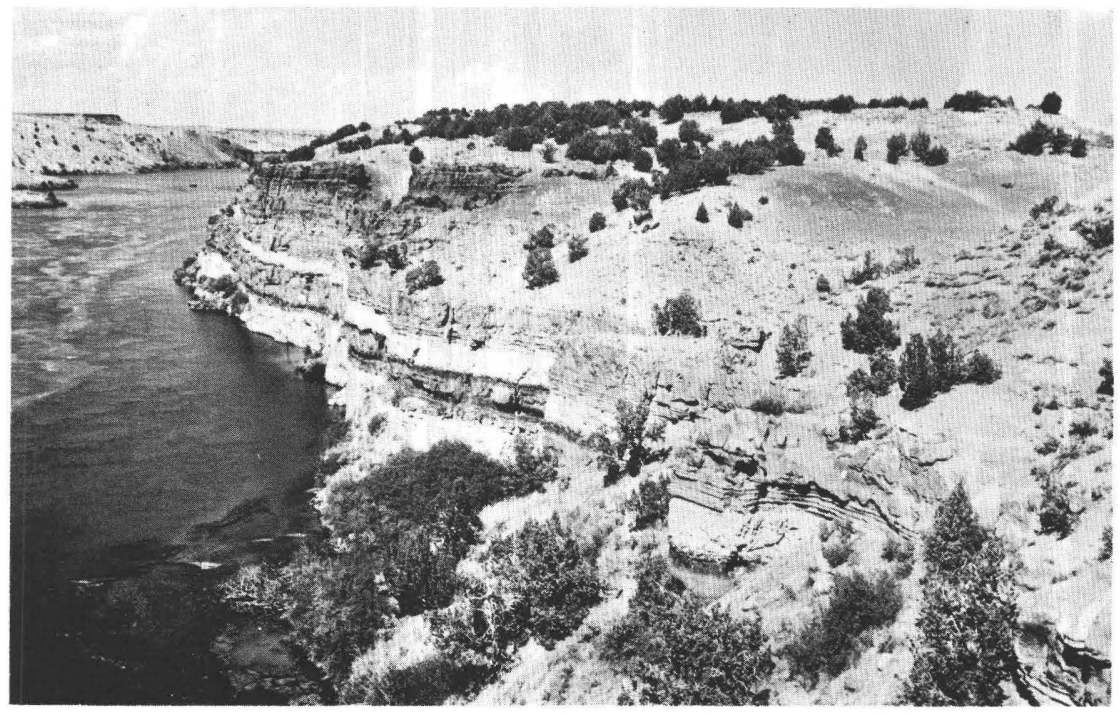

FIGURE 10.-Upper part of Tertiary sequence on the south side of the Snake River near viewpoint in the SW. cor. sec. 29 , T. 8 S., R. 30 E., Rockland quadrangle. Neeley Formation is at base of cliff. Walcott Tuff overlies the Neeley, and Little Creek Formation forms the upper half of the cliff, above the black band of obsidian welded tuff of the Walcott.

welded part is more than 20 feet thick. Local relief of the surface upon which the Walcott was deposited was probably not great, perhaps nowhere more than 50 feet. The ash-flow member, unlike the lower bedded member, seems to have had a definite tendency to "puddle" in depressions, resulting in a considerable thickening of the unit in some areas. The ash-flow member thins and disappears where the formation laps up on the foothills of the Deep Creek Mountains. In the lower 2-7 feet of the member, black glassy welded tuff grades progressively downward to brownish-gray soft porous tuff at the base. The dark central part of the welded tuff grades upward in the upper few feet of the member at most places into black fine-textured welded tuff that becomes pink or brick-red glassy welded tuff at the top. Faint horizontal partings in the pink tuff cause it to break into platy fragments. At a few places, including one south of Massacre Rocks and north of the pinchout east of Rock Creek, soft unwelded tuff as much as 34 feet thick locally overlies the pink tuff; elsewhere equivalents of these soft upper beds probably have been eroded away. At its southernmost exposure the upper member consists only of gray massive friable tuff more than 5 feet thick, which overlies about 5 feet of the lower bedded tuff member. At the easternmost exposures north of Rock Creek, the upper 


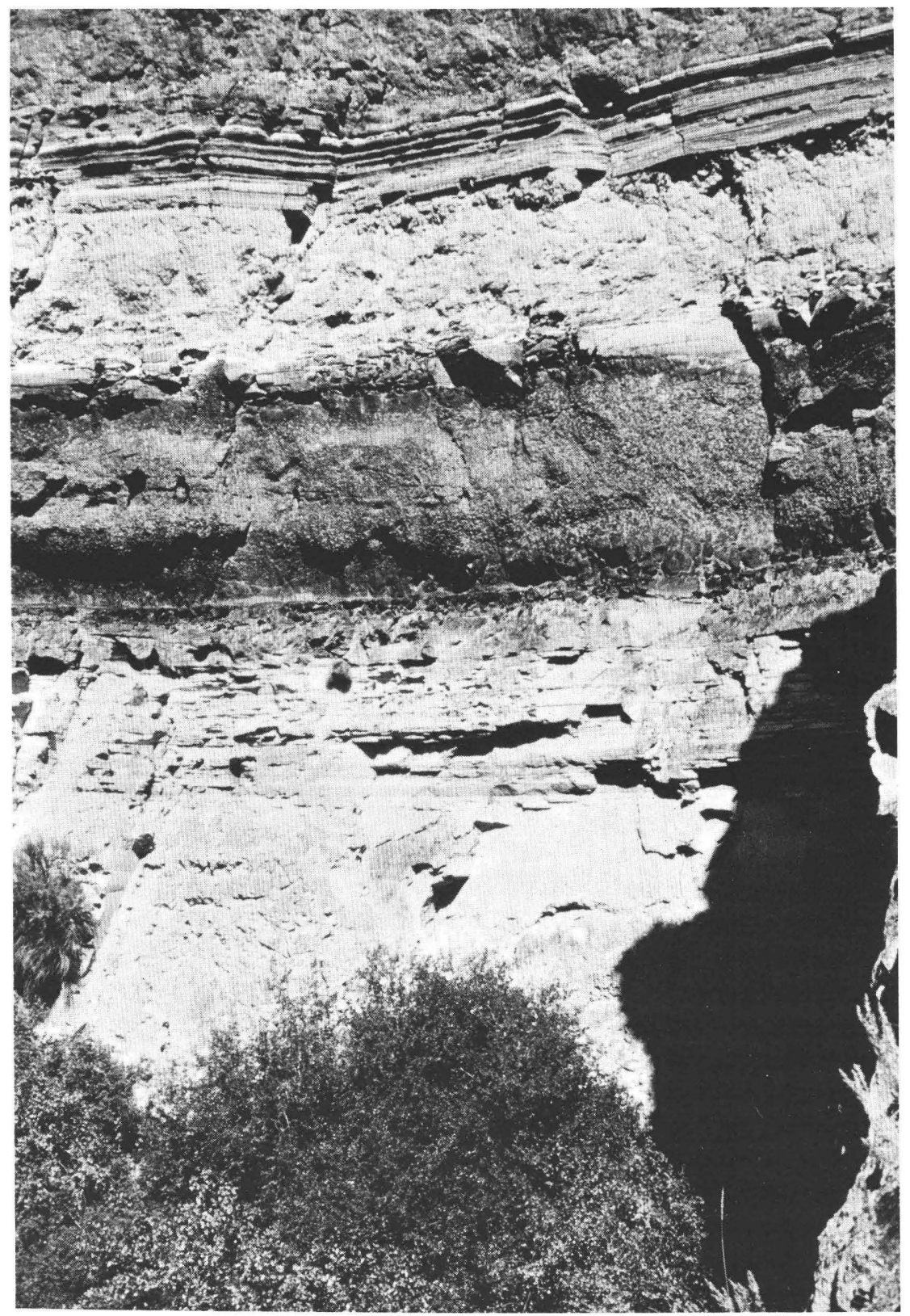

FIGURE 11.-Base of cliff exposure on south side of the Snake River near viewpoint in the SW. cor. sec. 29 , T. 8 S., R. 30 E., Rockland quadrangle. Massive tuff in lower part of cliff is Neeley Formation. Bedded tuff and obsidian welded tuff above are the Walcott Tuff. Massive bed above the Walcott is colluvial deposit included with the bedded tuff of the overlying Little Creek Formation. 


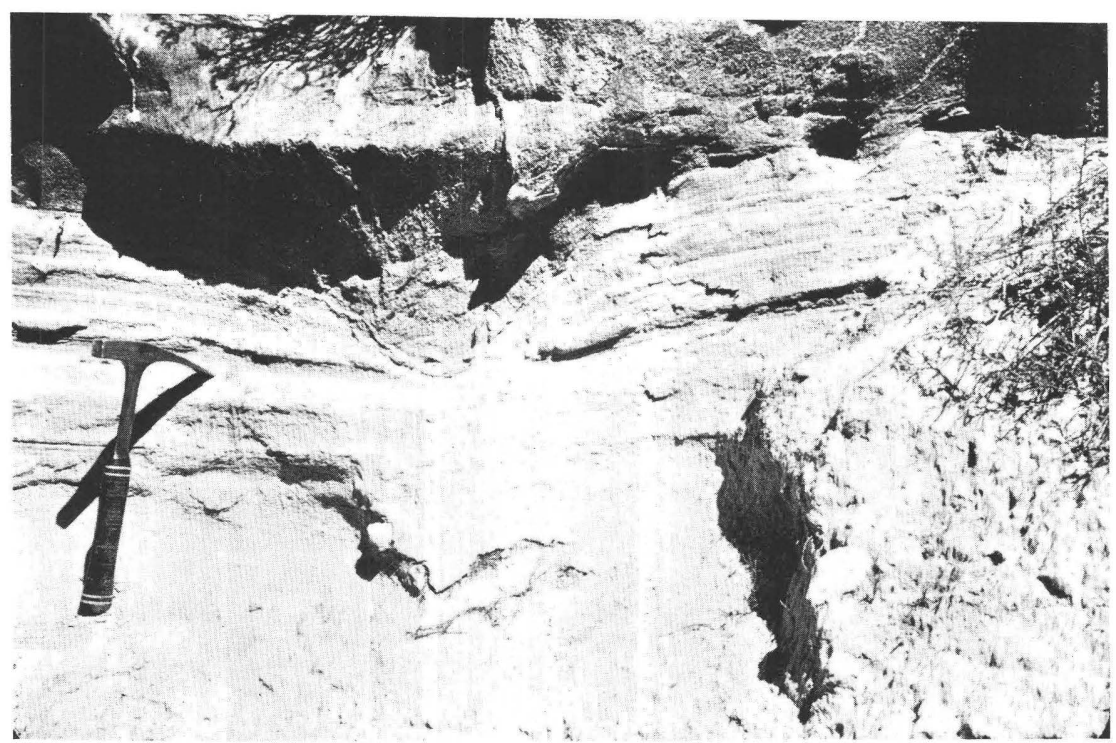

FIGURE 12.-Bedding in tuff of the lower member of the Walcott Tuff deformed by overlying upper ash-flow tuff member in Ferry Hollow, NW $1 / 4$ sec. 6, T. 8 S., R. 31 E., American Falls quadrangle.

member is 6-8 feet thick and contains some black perlitic obsidian welded tuff. Farther west, the pink welded phase rests directly on the lower gray porous phase. These variations in the welded-tuff member probably reflect mainly distance from the margin of the ash flow and some local zonation, as illustrated diagramatically by Smith (1960, pl. 20). In Smith's terminology the upper member of the Walcott is a simple cooling unit. It probably was formed by only one or two ash flows. The following measured section is typical of most of the Walcott:

SECTION G.-Walcott Tuff, measured in lower Ferry Hollow, in the $S W^{1 / 4} N E^{1 / 4}$ sec. 6, T. 8S., R. 31 E., American Falls quadrangle, Idaho

Composite section

Little Creek Formation.

Unconformity.

Walcott Tuff (upper obsidian welded tuff member):

Obsidian tuff, welded, black; about 10-percent white rectangular feldspar crystals $1 \mathrm{~mm}$ long; grades upward abruptly into a thin zone of pink to brick-red glassy welded tuff having faint horizontal lineation; breaks with conchoidal fracture, except pink to red top part, which forms platy

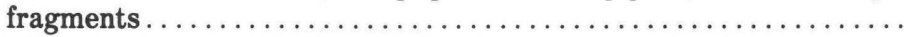

Obsidian tuff, welded, black nonspherulitic ................

Obsidian tuff, welded, black, massive, perlitic and friable; contains about 25-percent gray spherulites $1-35 \mathrm{~mm}$ in diameter; the spherulites are 
SECTION G. - Walcott Tuff, measured in lower Ferry Hollow, in the SW $W^{1 / 4} N^{1 / 4}$ sec. 6, T. 8S., R. 31 E., American Falls quadrangle, Idaho-Continued

Walcott Tuff (upper obsidian welded tuff member)-Continued

Obsidian tuff-Continued

Thickness (feet)

solid, have a small core, have crude radial structure, and increase in

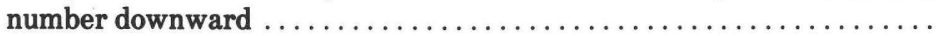

Obsidian tuff, welded, black, massive, breaks with smooth conchoidal fracture; contains a few scattered white feldspar crystals; much of unit has a fine "granular" vesicular texture; no apparent lineation ........

Obsidian tuff; gray and soft at base to dark-gray hard and welded at top; massive, porous; contains scattered small white feldspar crystals; shards are flattened in horizontal plane; lower part has many

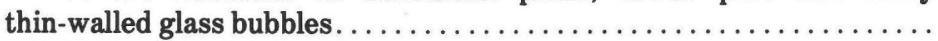
Walcott Tuff (lower bedded tuff member):

Tuff, bedded, white to light-gray, medium-grained, friable; varies in induration; uniformly well bedded in layers 6 in. thick to thin laminae; composed almost entirely of clear shards; contains ash pellets as much

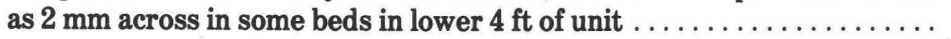

Total Walcott Tuff $\ldots \ldots \ldots \ldots \ldots \ldots \ldots \ldots \ldots \ldots \ldots \ldots$

Neeley Formation:

Tuff, light-tan, fine-grained, massive, friable.

Base of exposures.

The lower contact of the Walcott Tuff with the underlying Neeley is sharp and conformable and is marked by the abrupt change from massive tan tuff of the Neeley to well-bedded white to light-gray tuff of the lower member of the Walcott.

Fossils have not been found in the Walcott Tuff, but the conformable contact with the Neeley Formation and the presence, in both, of nearly pure rhyolitic shards suggest that the Walcott was deposited soon after the Neeley and that its age is also middle Pliocene. This conclusion is verified by radiometric dates on samples of the ash-flow tuff of the Walcott Tuff, collected by D. C. Noble of the U.S. Geological Survey, which yielded ages of $6.7 \pm 0.4$ and 6.1 \pm 0.3 million years (R. L. Christiansen, oral commun., 1969).

Welded obsidian tuffs in the northwestern part of the Ammon quadrangle southeast of Idaho Falls resemble the Walcott Tuff very closely. Rocks similar to the Neeley and Starlight Formations are also present beneath the obsidian tuff in the Ammon area. The lithologic and stratigraphic resemblance is so great that these tuffs almost certainly belong to the same epoch of rhyolitic eruptive activity-if not to the same source-as the Walcott. The obsidian tuff near Ammon and the Walcott Tuff were correlated by Mansfield and Ross (1935, p. 310). As discussed earlier (under the heading "Age and Correlation" of the Starlight Formation) Mansfield's conclusion that the welded tuff of the Ammon area is Pleistocene in age seems unwarranted. 


\section{TERTIARY OR QUATERNARY SYSTEM}

\section{LITTLE CREEK FORMATION}

Rocks that were called Massacre Volcanics by Stearns (Stearns and others, 1938, p. 46-47; Stearns and Isotoff, 1956, p. 24-27) were divided by the writers (Carr and Trimble, 1963, p. G19) into two formations locally separated by an unconformity. The older of these is the Little Creek Formation, which is overlain by the Massacre Volcanics as redefined in 1963 . The Little Creek Formation was named from exposures along the creek of that name in the northern part of the Rockland quadrangle. Basalt that was considered to be part of the Little Creek Formation (Carr and Trimble, 1963, p. G19-G21) now is known to overlie the Little Creek with angular unconformity and is here separated from it and restored to the Massacre Volcanics. The Little Creek Formation as redefined in this report, consisting of tuff and tuff breccia, is found in the report area only in the northern part of the Rockland quadrangle. Northeast of Rock Creek the Little Creek underlies basalt of the Massacre Volcanics in Rockland Valley as far south as sec. 13, T. 9 S., R. 30 E. West of Rock Creek the Little Creek occurs as far south as the south rim of Table Mountain.

The Little Creek varies greatly in thickness. The formation, which is nearly 75 feet thick near the viewpoint along the Snake River, is only 15-20 feet thick just north of Rock Creek and 5-6 feet thick at the south rim of Table Mountain. East of Rock Creek the tuff is about 30 feet thick in the NW ${ }^{1 / 4}$ sec. 13, T. 9 S., R. 31 E.; it is not present at Rocky Hollow, $2^{1 / 2}$ miles north of Rockland.

The tuff of the Little Creek contains both rhyolitic and basaltic constituents. Rhyolitic material is more common at the base. Most of the tuff of the Little Creek consists of basaltic cindery tuff and tuff breccia that is light yellowish brown to dark purplish gray. At most localities the tuff is bedded, but at some places massive tuff and tuff breccia constitute the formation, as in the southern tributary of Little Creek in sec. 36 , T. 8 S., R. 30 E. The Little Creek in the vicinity of Massacre Rocks contains many large ejecta of older rocks. This, and the fact that the unit there is as thick as it appears to be anywhere, suggests that a vent near Massacre Rocks was a major source of the Little Creek. Massive tuff and tuff breccia in the valley tributary to Little Creek suggest a subsidiary vent near that locality. The lithology of the formation indicates that basaltic and rhyolitic pyroclastic rocks accumulated together, some in ponds and lakes. Variations in lithology of the Little Creek Formation are illustrated by the measured sections on the following pages.

The Little Creek unconformably overlies the Walcott Tuff at most localities, but on and near Table Mountain it overlies the Starlight 
SECTION F.-Little Creek Formation, measured in a steep ravine in the $N W^{1 / 4} S W^{1 / 4} S W^{1 / 4}$ sec. 28, T. 8 S., R. 30 E., Rockland quadrangle, Idaho

Top of exposure.

Little Creek Formation:

Tuff breccia, basaltic; brown at top to dark-gray at base; massive; fluted with more or less vertical grooves as much as $2 \mathrm{ft}$ deep and 3 in. across; contains abundant basaltic cinders and accidental fragments, including pieces of marl of the Neeley Formation and of obsidian and spherulitic obsidian tuff of the Walcott Tuff, in a matrix of fine-grained basaltic and

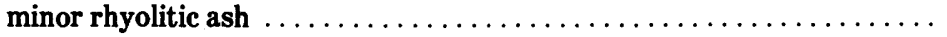

Tuff, basaltic, dark-gray to purplish-gray, faintly bedded; consists mainly of basalt cinders, but contains a few accidental ejecta like those in unit

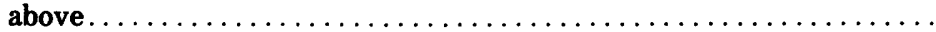

Tuff, basaltic, yellowish-brown, massive, well-indurated; forms ledge in lower part; contains accidental fragments like beds above; contains a

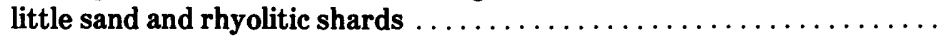

Breccia, basaltic, light-gray to yellowish-tan, massive, moderately indurated; contains basaltic cinders and a few large blocks, as much as 4 $\mathrm{ft}$ across, of several phases of the Walcott Tuff, vitrophyre of the Starlight Formation, and marl or claystone of the Neeley Formation; locally cemented by secondary calcite; also contains some rhyolitic shards and yellowish pumice, particularly in upper part ................

Tuff, basaltic, lapilli, olive-brown to dark-red, fairly massive; some faint crossbedding; contains some quartz sand and quartzite pebbles, as well as a few accidental fragments as much as 6 in. across . . . . . . . . . . .

Sandstone, $\tan$ to yellow, tuffaceous, palagonitic, and well-indurated but porous cindery lapilli basaltic tuff; at the top is a 0.5 - $\mathrm{ft}$ layer of lightgray clay with a few rhyolitic shards and thin laminae of basaltic sand . .

(Top of "formation B," as used by Stearns and Isotoff, 1956)

Clay, tan; possibly diatomaceous in places; slightly calcareous; in beds $1-4$ in. thick; interbedded and alternating in upper part with laminae and beds of obsidian grains, quartz sand, rhyolitic shards, and small palagonitic basalt cinders, the latter becoming more abundant upward; graded bedding well developed in places; moderately indurated .......

(Base of "formation B," as used by Stearns and Isotoff, 1956)

Silt, light-pinkish-tan, very ashy, massive; slightly calcareous in places, local nodular weathering; contains many rhyolitic shards, a few obsidian pellets, and, at the base, a few blocks and chips of the pink phase of the Walcott . . . . . . . . . . . . . . . . . . . . . .

Total Little Creek Formation exposed $\ldots \ldots \ldots \ldots \ldots \ldots \ldots \ldots \quad \frac{9.5}{73.0}$ Walcott Tuff:

Tuff, welded, pink; a few thin carbonate seams in cracks parallel to bedding.

SECTION E.-Little Creek Formation, measured in Ferry Hollow, in the $S_{W^{1} / 4 E^{1 / 4}}$ sec. 6, T. 8 S., R. 31 E., American Falls quadrangle, Idaho

Gravel; locally well cemented by caliche; contains pebbles and cobbles of obsidian welded tuff of the Walcott.

Little Creek Formation:

Tuff breccia, tan to light-gray, poorly sorted; contains pieces mainly of

Walcott Tuff, as much as $1 \mathrm{ft}$ across, in a shardy matrix ........... 
SECTION E.-Little Creek Formation, measured in Ferry Hollow, in the SW1/4NE $1 / 4$ sec. 6, T. 8S., R. 31 E., American Falls quadrangle, Idaho-Continued

Little Creek Formation-Continued

Thickness

(feet)

Tuff, light-gray; contains grains of obsidian, pumice, and basalt cinders . .

Tuff, light-gray, well-stratified, waterlaid; contains basalt-cinder lapilli;

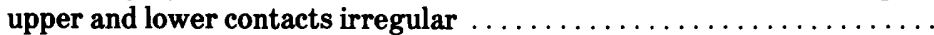

Tuff, dark-gray to tan, basaltic; poorly stratified in places; contains

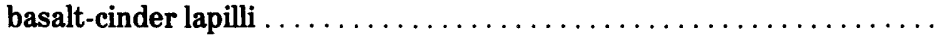

Ash, light-brown, sandy and clayey, poorly sorted; contains a few lenses of sand and fine gravel and many rhyolitic shards; at base is a zone of platy pieces of pink welded tuff of the Walcott in a soft white to tan

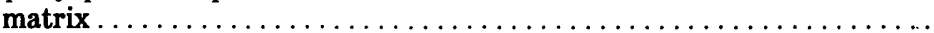

Total Little Creek Formation $\ldots \ldots \ldots \ldots \ldots \ldots \ldots \ldots \ldots \ldots$ Walcott Tuff:

Obsidian tuff, welded; black, grading up into pink.

SECTION D.-Little Creek Formation, measured in the SE $1 / 4 N^{1 / 4}$ sec. 13, T. 9 S., R. 30 E., Rockland quadrangle, Idaho

Top of exposure.

Massacre Volcanics:

Basalt, dark-gray, fine-grained, dense; a little visible olivine; diktytaxitic texture in places; crudely jointed in 2- to 3-ft-thick vertical columns . . 10.0

Little Creek Formation:

Tuff, light-gray, lithic, massive; abundant small basaltic glass fragments; some rhyolitic shards and pumice; upper few feet covered . . . . . . . . .

Sand and silt, light-tan, slightly calcareous, well-sorted; interbedded with rhyolitic ash; partially cemented with calcium carbonate and clay; grades upward into light-brown massive lithic tuff, with local lenses of

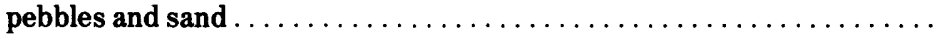

Gravel; mainly well-rounded pebbles of chert, opal, and quartzite and a few pebbles of obsidian, all loosely cemented in a white limy ashy

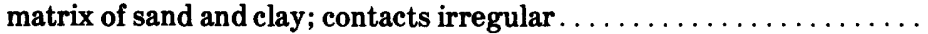

Total Little Creek Formation $\ldots \ldots \ldots \ldots \ldots \ldots \ldots \ldots \ldots \ldots, \overline{\mathbf{3 0 . 3}}$

Walcott Tuff:

Tuff and bedded ash, white to light-gray, rhyolitic.

Formation. A thin zone of colluvium or alluvial gravel commonly forms the base of the Little Creek. The zone containing platy fragments of Walcott Tuff in section G, measured at Ferry Hollow, probably is an ancient colluvial accumulation, and stream-laid gravel is at the base of section E, measured on the east side of Rock Creek valley. The so-called "formation A" of Stearns and Isotoff (1956, p. 23), where present, is the basal unit of the Little Creek and is, in many places, an ancient colluvial deposit.

Fossils have not been obtained from the Little Creek Formation, except for some diatoms whose age has not been determined. The underlying formations are all of middle Pliocene age, and the 
overlying dated one (Raft Formation) is middle or late Pleistocene in age. The Little Creek Formation is therefore probably late Pliocene or early Pleistocene.

\section{MASSACRE VOLCANICS}

The Massacre Volcanics as redefined in this report consist of basaltic tuff, flows, and breccias that overlie tuffs and breccias, containing no flows, of the Little Creek Formation. The Massacre Volcanics are older than the Raft Formation. They crop out along the Snake River and south of it. They include basaltic rocks from several different vent sources. At Eagle Rock, basaltic pyroclastic rocks and associated flows that are clearly younger than the Little Creek (on which they rest with angular discordance) are referred to the Massacre Volcanics. Basalt flows that underlie Table Mountain, west of Rock Creek, also are assigned to the Massacre Volcanics; these flows, which extend as far south as sec. 15, T. 10 S., R. 30 E., overlie the Little Creek with slight angular discordance at one locality on Table Mountain in the $\mathrm{SE}^{1 / 4} \mathrm{SW}^{1 / 4}$ sec. 29 , T. 9 S., R. 30 E. A single thin basalt flow underlies much of the northern part of the Rockland quadrangle north of Rocky Hollow, east of Rock Creek. Although it was formerly considered to be part of the Little Creek Formation (Carr and Trimble, 1963, p. G19-G21), the basalt flow is petrographically similar to the basalt on Table Mountain and is here reassigned to the Massacre. This flow and the basalt at Table Mountain probably are part of what has been called the Rockland Valley Basalt by Stearns, Crandall, and Steward (1938, p. 47). The Rockland Valley is therefore abandoned.

Basalt east of Bannock Creek and north of Rattlesnake Creek in the Arbon quadrangle overlies tuff of the Starlight Formation with angular unconformity and may be equivalent to the Massacre Volcanics.

Dikes, plugs, cindery tuffs, and flows at near Massacre Rocks, from which the unit takes its name, intrude or incorporate basaltic rocks that were extruded from a vent at Eagle Rock. Flows from the Massacre Rocks source are petrographically similar to those on Table Mountain and in Rockland Valley east of Rock Creek.

The basalt flows of the Massacre Volcanics are generally thin, mostly between 5 and 30 feet thick. The tuff and breccia vary greatly in thickness.

Pyroclastic rocks of the Massacre Volcanics are similar to those of parts of the Little Creek Formation. The tuffs of the Massacre, however, appear to contain very little rhyolitic material, whereas most of the tuff of the Little Creek Formation contains at least small amounts of rhyolitic shards. Large accidental ejecta also seem to be more common in the Little Creek than in the Massacre. At a good 
exposure of Massacre Volcanics on the northeast side of Eagle Rock, the formation from the base upward consists of at least 50 feet of massive red-brown to gray basaltic tuff containing many round concretions, overlain successively by: About 5 feet of gray to dark-red well-bedded basaltic lapilli tuff; about 10 feet of gray well-indurated massive ledge-forming basaltic tuff with a few lapilli; about 30 feet of massive gray-brown to dark-red basaltic tuff breccia; and, at the top, at least 50 feet of red-brown poorly consolidated basaltic cinders.

Basalt flows overlie the pyroclastic rocks of the Massacre at both the Eagle Rock and the Massacre Rocks vent areas, and basalt covers wide areas in Rockland Valley east and west of Rock Creek. Two types of basalt are recognized in the Massacre Volcanics. The older type, from the vent area at Eagle Rock, is very dense dark-gray fine-grained basalt that characteristically contains a few small fragments of pyroclastic rock. Olivine commonly is not megascopically visible and composes less than 10 percent of the rock. In contrast, the plugs, dikes, and flows of the Massacre Rocks vent area are much coarser grained than is typical of basalt, and they have a diktytaxitic texture - that is, an open meshwork of crystals with cavities or voids between the crystals. Olivine locally composes as much as 20 percent of the basalt at Massacre Rocks, in Rockland Valley east of Rock Creek, and on Table Mountain. The olivine is commonly altered and is reddish brown and iridescent. The flows east of Rock Creek and on Table Mountain commonly are gray to dark-gray dense fine-grained relatively fresh looking olivine basalt with patches-mostly in the upper part of the flow-of diktytaxitic texture. Much of the rock has streaky flow banding or platy jointing parallel to the banding.

At the base of the Massacre Volcanics an unconformity with the underlying Little Creek Formation is demonstrated at several localities (fig. 13). The Little Creek and the underlying beds are deeply channeled at the viewpoint on the south side of the Snake River and are overlain by thick volcanic mudflow breccia of the Massacre that fills the channel. The course of the channel westward is shown by the breccia and associated tuff, which forms the south bluff of the Snake River canyon downstream to the vicinity of Massacre Rocks. Basalt of the Massacre overlies the Little Creek with angular discordance at several localities (two of which have already been cited) and disconformably at others.

At an exposure near the mouth of Little Creek, in the SW ${ }^{1 / 4} \mathrm{SE}^{1 / 4}$ sec. 15, T. 8 S., R. 30 E., basaltic tuff of the Little Creek Formation appears to grade into an overlying basalt sequence, which consists of a very thin tongue of basalt from the Eagle Rock vent, overlain sharply by thin basalt that probably came from Rockland Valley. The 


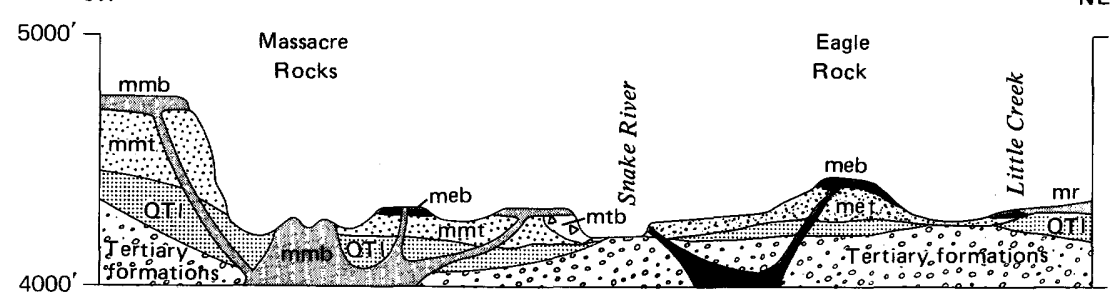

FIGURE 13.-Diagrammatic sketch of the physical relations between the Little Creek Formation and the Massacre Volcanics, both of which are Tertiary or Quaternary in age. QTI, Little Creek Formation. Massacre Volcanics: met, tuffs from the Eagle Rock vent area; meb, basalt from the Eagle Rock vent area; mr, basalt from the east side of Rockland Valley; mmt, basaltic tuffs in Massacre Rocks vent area; $m$ tb, tuff and breccia of Massacre Volcanics undifferentiated; $\mathrm{mmb}$, basalt in the Massacre Rocks vent area. Length of section about $41 / 2$ miles. No vertical exaggeration.

contact of the basalt with the tuff is marked by a gradual downward increase in the number of pyroclasts. The underlying tuff probably represents a mixture of tuff of the Little Creek and tuff of the Massacre from the Eagle Rock vent and indicates a virtual contemporaneity of part of the Little Creek with part of the Massacre.

Like those of the Little Creek Formation, rocks of the Massacre Volcanics are unfossiliferous, but they are probably either late Pliocene or early Pleistocene in age.

\section{QUATERNARY SYSTEM}

\section{RAFT FORMATION}

Massive beds of light-colored silt and clay, and laminae and thin beds of silt and sand are widely distributed along the Snake River as far west as the mouth of the Raft River. These beds and laminae were named the Raft Lake Beds by Stearns, Crandall, and Steward (1938, p. 48). The name has subsequently been changed by us to the Raft Formation (Carr and Trimble, 1963, p. G22). Along the Snake River the Raft Formation generally overlies the Massacre Volcanics or the Little Creek Formation. The Raft, which apparently is continuous into Rockland Valley, is exposed in a roadcut, at an altitude of about 4,650 feet, in the $\mathrm{NW}^{1 / 4} \mathrm{NW}^{1 / 1} / 4$ sec. 2 , T. $9 \mathrm{~S}$., R. 30 E. East of Rock Creek the southernmost exposure of beds thought to be Raft is at the bend in the highway in sec. 17, T. 9 S., R. $31 \mathrm{E}$. Probable Raft overlies the Starlight Formation west of Rock Creek at several places west of Central School and at one place northwest of Excelsior School. Less than 100 feet of the Raft Formation is exposed in the Rockland quadrangle, but the formation is at least 233 
feet thick in a bluff east of the Raft River, on the south side of the Snake River 10 miles west of the Rockland quadrangle.

The Raft Formation in the mapped area is composed mainly of parallel-bedded calcareous quartzose silt and fine sand that is crossbedded locally. Nodular calcareous concretions in many beds characterize the formation. Where the formation is thicker, west of the Rockland quadrangle, the upper 100 feet is massive thick-bedded silt. Conglomerate or gravel as much as $\mathbf{1 0}$ feet thick occurs at the base of the Raft Formation in the NW $1 / 4$ sec. 33, T. 8 S., R. 30 E., and at several places in Rockland Valley.

The following section was measured on the bluffs on the west side of the Snake River about 1 mile south of the north edge of the Rockland quadrangle (fig. 14). It also includes the overlying American Falls Lake Beds. Stearns and Isotoff (1956, p. 28) apparently included part of the section here referred to the Raft Formation in the American Falls Lake Beds. This is evident from their assignment of a thickness of more than 100 feet for the American Falls Lake Beds in this general locality, and their mention of basaltic tuff in the American Falls Lake Beds, which we include within the Raft. We have placed the contact between the Raft and the American Falls at the base of a persistent gravel layer.

SECTION C.-American Falls Lake Beds and Raft Formation, measured in the west bank of the Snake River opposite Neeley, in the $S E^{1 / 4} S W^{1 / 4}$ sec. 10, T. 8 S., R. 30 E., Rockland quadrangle, Idaho

Top of bluff.

Dune sand:

Sand, gray to tan, fine to medium, poorly indurated $\ldots \ldots \ldots \ldots \ldots$ 10 - 15

American Falls Lake Beds:

Clay, gray-green, noncalcareous. Breaks into small conchoidal fragments

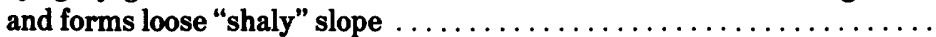

Clay, white to light-tan, diatomaceous, massive, blocky; local platy and prismatic jointing, particularly near top. Forms ledge ............

Clay, greenish-gray; sandy and pinkish brown in lower $2.5 \mathrm{ft}$; slightly calcareous. Blocky fracture at top; breaks into fine granular or "shaly" rubble. Upper contact sharp . . . . . . . . . . . . . . . . . . . .

Sand, pinkish-brown, calcareous, fine, poorly indurated; has a few pinkish-brown clay layers near the bottom. Upper contact gradational .

Clay, pinkish-brown, calcareous, laminated, brittle; in beds $0.5-2$ in. thick, alternating with tan crossbedded silt in layers 6-18 in. thick. Silt shows wavy bedding. Contains mollusks; forms ledge ..........

Sand, gray to tan, fine to very fine, poorly indurated. Crossbedded on small scale; locally contains thin silty layers. . . . . . . . . . . . . .

Gravel, coarse, pebbly, moderately indurated. Well-rounded pebbles consist mainly of quartzite (about 80 percent) but also of basalt and Walcott Tuff. Layer of yellow clay containing rhyolitic shards and basalt cinders, about 0.5 in. thick, at base. Contains mollusks. Thickens to about $5 \mathrm{ft}$ about $30 \mathrm{ft}$ downriver from line of section . . . . . . . . . .

Total American Falls Lake Beds 
SECTION C.-American Falls Lake Beds and Raft Formation, measured in the west bank of the Snake River opposite Neeley, in the $S E^{1 / 4} S W^{1 / 4}$ sec. 10, T. 8 S., R. 30 E., Rockland quadrangle, Idaho-Continued

Raft Formation:

Silt, light-tan, massive; poorly indurated, but forms ledge . . . . . . . . .

Clay and silt, calcareous, laminated; a layer of light-brown loose sand at top of unit. Upper contact gradational. . . . . . . . . . . . . . . . . .

Sand, tan to light-gray, well-bedded; locally crossbedded, with several pebbly sand lenses; beds $3-4$ in. thick. Well-rounded pebbles are less than 0.5 in. in diameter; unit is composed of Paleozoic rocks and a few

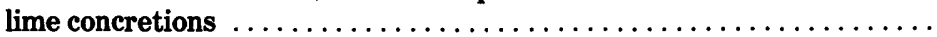

Silt, tan, calcareous, moderately indurated, massive; has lenses of

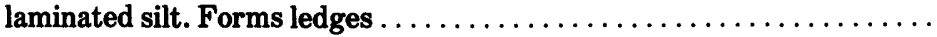

Sand, light-gray to tan, fine, clean, loose; interbedded with $\tan$ thinbedded to laminated silt with platy partings and some crossbedding. Pebbly zones about 4 in. thick about $2 \mathrm{ft}$ above base and at top of unit. Lower pebbly zone contains small concretions, platy fragments of Walcott, and sparse quartzite . . . . . . . . . . . . . . . . . . .

Silt and fine sand, light-tan to tan, calcareous, moderately well cemented, massive, ledge-forming; fractured case-hardened surface in places along some prismatic jointing; hard irregular concretionary areas in lower and middle parts of unit $\ldots \ldots \ldots \ldots \ldots \ldots \ldots \ldots \ldots \ldots \ldots$

Sand, tan, very fine to coarse; very loosely cemented by films of calcium carbonate; granular texture in places; contains a few shards and scattered white soft calcareous lumps, 1-6 mm across, and lenses of pumice fragments and pebbles of Walcott (?) Tuff; upper contact gradational. Approximate horizon of basaltic ash exposed about 0.25 mile

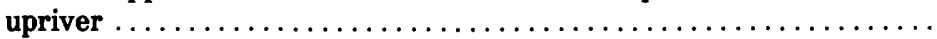

Sand, fine, and silt; tan, calcareous; in beds $4-5$ in. thick; sand beds contain 0.5- to 3-mm-thick white irregular calcareous particles and very irregular calcareous sandstone concretions, many of which are spindleshaped, as much as $1 \mathrm{ft}$ long, and perpendicular to the bedding .......

Silt, tan, calcareous, moderately indurated; massive to faintly bedded; includes very little very fine sand and several zones of concretions in lower part; forms ledge with unit above . . . . . . . . . . . . . . .

Sand and silt, light-tan, calcareous; in alternating beds $1-4$ in. thick, with prominent concretion zone at top $\ldots \ldots \ldots \ldots \ldots \ldots \ldots \ldots$.

Sand, tan, calcareous, fine to very fine, mostly quartz, crossbedded; contains three or four discontinuous zones of nearly pure calcareous con-

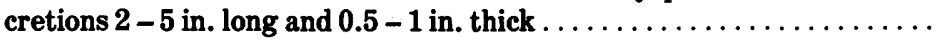

Silt and sand, light-tan, calcareous, fine, poorly indurated; contains platy layers and 1-in. nodules of calcareous moderately indurated sand ......

Total Raft Formation measured $\ldots \ldots \ldots \ldots \ldots \ldots \ldots \ldots \ldots \ldots$

13.8

Base of section-15 ft above river level.

A more nearly complete section of the Raft Formation was measured (measured section B) on the south bank of the Snake River near the mouth of the Raft River about 6.5 miles downstream from Massacre Rocks. Section B shows a marked difference in bedding between the thick-bedded upper 100 feet and lower thinner bedded 


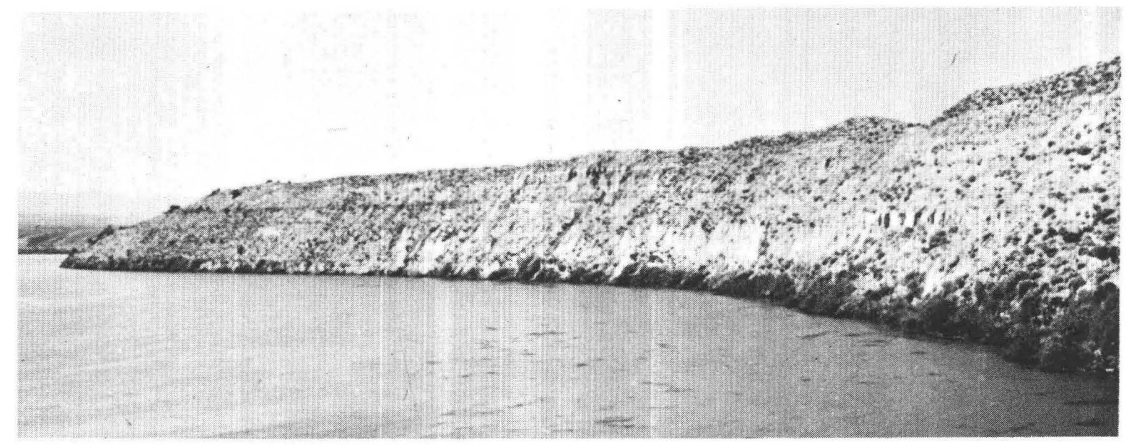

FiguRE 14.-Raft Formation and overlying American Falls Lake Beds in bluff on west side of the Snake River opposite Neeley in the Rockland quadrangle. Dark line of vegetation, two-thirds the way up the bluff, marks the contact between the two formations. Thin gravel at the base of the American Falls Lake Beds forms an aquifer that accounts for the growth of vegetation. Gravel is graded to base of basalt flow that dammed the Pleistocene Snake River. Remnants of the margin of the basalt dam are on both sides of the river farther downstream.

part of the formation. Measured section $\mathrm{C}$ may include only the lower part of the Raft; the upper part may be missing beneath the unconformably overlying the American Falls Lake Beds.

SECTION B.-Raft Formation, measured on the south bank of the Snake River in the $S W^{1 / 4}$ sec. 23, T. 9 S., R. 28 E., about 6.5 miles downstream from Massacre Rocks

Top of bluff.

Raft Formation (part):

Silt, massive, calcareous; vertical columnar jointing to the surface .......

Silt, massive, calcareous; nodular weathering toward the top ..........

Silt, brown to light-tan, massive, calcareous; moderately indurated, much like that below; scattered pebbles and fragments of basalt, mostly irregular and angular, in a 1 -ft-thick zone at the base............

Silt, light-brown, massive, calcareous; faint bedding in places . . . . . . . .

Sand, light-brown, massive, fine, calcareous, slightly indurated. Unit becomes finer grained and siltier upward. Silt at top; faintly bedded ...

Silt, clayey; light tan with slightly greenish tinge; poorly bedded, calcareous, slightly indurated; a few scattered small calcareous nodules in

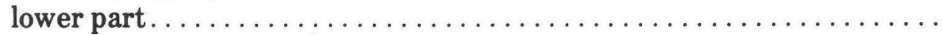

[The following part of the section was measured 200 yards west of the preceding location. Interval occupied by unit above is a sand containing local lenses of pebbles]

Clay; brownish at base, becoming tan and more silty upward. Faint bedding. A 6-in. layer of greenish-gray brittle clay near top is overlain by a 1-ft layer of white blocky clay that is very calcareous. Upper part of this unit is cut out locally by the overlying alluvial sand and gravel...

Sand, silty, tan, very fine to fine, calcareous, thin-bedded to laminated. A few irregular calcareous nodules. Top contact irregular, channeled, and

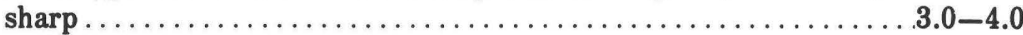


SECTION B.-Raft Formation, measured on the south bank of the Snake River in the $S W^{1 / 4}$ sec. 23, T. 9 S., R. 28 E., about 6.5 miles downstream from Massacre Rocks-Continued

Raft Formation (part)-Continued

Thickness

(feet)

Silt, light-tan, very fine, powdery, calcareous, well-bedded; layers range from laminae to beds $2 \mathrm{ft}$ thick. Some wavy crossbedding. A few small calcareous nodules and plates in upper part. Some fragile Sphaeriumlike clam shells in upper part.

Clay, similar to unit below, but siltier; interbedded with tan calcareous silt; bedded in layers ranging from laminae to beds $3-4$ in. thick; silt proportion increases upward; all calcareous.

Clay, light-brown, calcareous, blocky, plastic. Lower contact fairly sharp .

Sand, light-brown to tan, very fine, silty; slightly indurated at base; grades upward into tan massive silt; all calcareous; 6-in. layer of yellowish medium sand near top.

[The following part of the section was measured about a quarter of a mile east of the preceding (second) location]

Silt and sand; many ledges of caliche. Persistent layer. A resistant layer that forms top of steep lower cliffs . . . . . . . . . . . . . . . . . . .

Sand, very light gray, fine to medium, massive. Contains a few hard calcareous nodules as much as $1 \mathrm{ft}$ in diameter. Layer of platy caliche at top in places, but thickness variable ......................

Silt, tan; some loose strongly laminated very fine sand at base, grading upward into medium sand. More clayey, calcareous, and indurated upward. Less well bedded to massive at top. A few white mollusk shells in

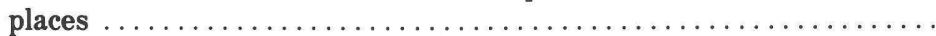

Sand, tan; mostly fine but some medium; well sorted, calcareous, well bedded; some crossbedding, alternating in somewhat indurated ledges with loose layers. Forms a slope in general, becomes coarser upward. Medium to coarse crossbedded sand in a few pockets at top. Grades up

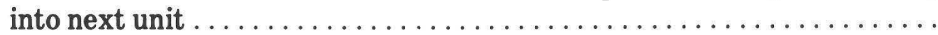

Silt, about the same as unit below, but lacks calcareous nodules. A few layers of fine to medium sand near top $\ldots \ldots \ldots \ldots \ldots \ldots \ldots \ldots$

Silt, much like unit below, but a little better indurated. A few clayey streaks. Locally abundant calcareous nodules ..................

Silt, light-tan, calcareous; a little very fine sand; laminated, wavy bedded

Sand, tan, medium to fine; has a few layers of white calcareous silt, 0.25 $3.0 \mathrm{in}$. thick. Sand is well sorted, has wavy bedding in places. Has a greenish tinge. A few irregular nodules or areas of hardpan or caliche. Very calcareous. Well indurated $\ldots \ldots \ldots \ldots \ldots \ldots \ldots \ldots \ldots \ldots \ldots$

Silt, light-tan, very calcareous, clayey, brittle. Laminated in lower part; more clayey and thicker bedded $(1-2$ in. thick) at top ............

Sand, tan, fine to medium, well sorted, clean; mostly quartz, iron stained, slightly calcareous, slightly indurated. Grades up into next unit .......

Silt, $\tan$, a little very fine sand; calcareous; well bedded in laminae. Clayey in a few layers. Contacts gradational . . . . . . . . . . . . .

Clay, greenish-gray, silty, calcareous. Contacts gradational .........

Sand, light-brown, very fine, silty, very calcareous; thinly laminated bedding; contacts gradational . . . . . . . . . . . . . . . . . . .

Clay, light-brown, silty, crumbly; calcareous in spots; contact gradational

Silt; pale greenish tan when wet; clayey, calcareous; contains mollusk shells (Lymnaea and other fossils); contact gradational . . . . . . . .

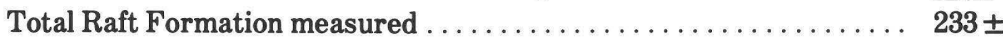

Base of section at river level. 
A brownish-tan massive rhyolitic tuff about 75 feet thick, atypical of the Raft but mapped as Raft, is well exposed along the east side of the Snake River from a point opposite Eagle Rock downstream for about 0.8 mile. Beds on the west bank downstream from Eagle Rock are also tuffaceous. The tuff overlies Massacre Volcanics and has about 3 feet of caliche at both base and top. It is overlain by Pleistocene alluvial gravel. A few feet of tuff breccia and stratified tuff underlies massive tuff at the base of the deposit at the west end of the exposure on the east bank. The rhyolitic tuff occupies the same stratigraphic position as the Raft Formation. It may represent a local eruption of rhyolitic ash during Raft time.

Stearns and Isotoff $(1956, p .27)$ assigned a tentative age of late Pliocene to the Raft Formation, but they did not find fossils. A few mollusks have been obtained during the present work from two stratigraphic levels in the Raft-one near the base and the other about halfway up a steep bluff along the south side of the Snake River in the SW ${ }^{1 / 4}$ sec. 24 , T. 9 S., R. 28 E., near measured section B. A third collection was made by D. W. Taylor from limy silt beds at the base of the west bank of the Snake River opposite Neeley. All these mollusks, in the list which follows, were identified by D. W. Taylor, who considers them to be middle or late Pleistocene, probably late Pleistocene in age (D. W. Taylor, written commun., 1959):

\author{
Freshwater clams: \\ Sphaerium striatinum (Lamarck) \\ Pisidium compressum Prime \\ Freshwater snails: \\ Valvata humeralis (Say) \\ utahensis Call \\ Stagnicola caperata (Say) \\ traskii (Tryon) \\ sp. a \\ sp. b \\ Gyraulus parvus (Say) \\ Land snails: \\ Pupilla indet. \\ Vallonia cyclophorella Sterki \\ cf. Succinea \\ Discus shimeki cockerelli Pilsbry \\ indet. \\ Oreohelix strigosa depressa (Cockrell)
}

\title{
PEDIMENT GRAVEL
}

Coarse gravel forms widespread aprons at the base of the mountains in both Rockland and Arbon Valleys. The gravel locally is more than 100 feet thick.

The gravel in Rockland Valley and Arbon Valley was derived almost entirely from the Paleozoic rocks in the adjacent mountains. 
It is bouldery near the base of the mountains and decreases in average grain size away from the mountains. Shapes range from subangular for some of the larger boulders and cobbles to well rounded for the pebble and cobbly pebble gravel 2 or 3 miles from the mountain front.

At the north edge of the Arbon quadrangle east of Bannock Creek, the gravel mantles a pediment surface cut on the Tertiary volcanic rocks. Elsewhere, the gravel locally overlies bedded silt that may be part of the Raft Formation, and at many places the gravel rests directly on the Starlight Formation. It is overlain in large areas by loess, locally as much as $\mathbf{2 0}$ feet thick. Travertine cements the gravel near the base of the Deep Creek Mountains in Rockland Valley and overlies it in some places, such as along the north side of Sand Hollow. These stratigraphic relationships indicate that most of the gravel probably is of late Pleistocene age, younger than the Raft Formation but mostly older than the loess deposits. The deposits as mapped, however, undoubtedly include some gravel of Holocene age. The pediment gravel may have been deposited on a surface graded to a higher base level that existed during the deposition of the Raft Formation.

\section{BIG HOLE BASALT}

Basalt flows north of the Snake River that unconformably overlie the Raft Formation and are widespread west of the American Falls Reservoir have been named the Big Hole Basalt (Carr and Trimble, 1963, p. G25). The Big Hole Basalt covers only a few square miles in the northwestern part of the Rockland quadrangle. The basalt is about 150 feet thick in a well about 3 miles north of the quadrangle margin but is thinner in other places. Its maximum thickness is not known.

The basalt characteristically is dense and blue gray to blue black; commonly, it contains a few megascopic olivine crystals. Locally, however, megascopic olivine is absent. In many places the flows have a pahoehoe surface that has buckled into pressure ridges.

The Big Hole Basalt is overlain locally by loess, dune sand, American Falls Lake Beds, or terrace deposits. The age of the Big Hole, therefore, is middle or late Pleistocene, probably late Pleistocene.

\section{TRAVERTINE}

Travertine and travertine-cemented conglomerate and breccia occur at several localities in the Rockland and Arbon quadrangles. Yellowish-white travertine as much as 6 feet thick overlies the Little Creek Formation in the valley of Warm Creek from a point near 
Indian Springs to a point near the community of Neeley. An isolated exposure of travertine apparently overlies basalt of the Massacre Volcanics on the east side of the valley of Rock Creek, in the $\mathrm{SW}^{1 / 4} \mathrm{NW}^{1 / 4}$ sec. 13, T. 9 S., R. 31 E. Several outcrops of travertine overlie alluvial pebbly silt or gravel that, in turn, rests on the Starlight Formation (1) on the north side of Rocky Hollow east of the highway between American Falls and Rockland (State Highway 37) (2) in secs. 28 and 29, T. 9 S., R. 31 E., between Rocky Hollow and Spring Creek and (3) along the valley of Spring Creek.

Travertine and travertine-cemented conglomerate and breccia are exposed in the valley of East Fork Rock Creek and in Sand Hollow and Dry Hollow in the Rockland quadrangle and are exposed in the area of Pete Lish Canyon, Howard Flat, and Warner Flat in the Arbon quadrangle. The thickest travertine deposits are adjacent to the frontal fault of the Deep Creek Mountains and to a normal fault of large displacement in the Arbon quadrangle. In Sand Hollow travertine-cemented conglomerate immediately adjacent to the frontal fault is about 200 feet thick and ends abruptly on the east at a breccia zone. In the valley of East Fork Rock Creek, it is more than 50 feet thick. Travertine is found downvalley from the fault for as much as 3 miles in some places and appears to be younger than the coarse pediment gravel in this area.

The volume of travertine-cemented breccia at the locality in the Arbon quadrangle is notable. An area more than 2.5 miles long and locally more than half a mile wide between Pete Lish Canyon and Warner Flat is completely covered. Locally, this deposit probably is more than 500 feet thick. The breccia is composed mainly of fragments $1 / 4-1 / 2$ inch across of Paleozoic rocks in a travertine matrix. Travertine-cemented sandstone and tuffaceous sandstone is locally interbedded with the breccia.

The common occurrences of travertine-cemented conglomerate and breccia adjacent to major faults, and the abundance of travertine near Indian Springs, a hot spring apparently on a fault line, indicate that the travertine was deposited by water containing a high percentage of calcium carbonate that issued from artesian springs along the faults.

A late Pleistocene age for most of the travertine is suggested by two lines of evidence. First, the isolated exposure of travertine overlying basalt east of Rock Creek, in the $\mathrm{SE}^{1 / 4} \mathrm{NW}^{1 / 4}$ sec. 13, T. 9 S., R. $30 \mathrm{E}$., contains mollusks of possible Pleistocene age (USGS Cenozoic loc. 21644). According to D. W. Taylor (written commun., 1959) "the absence of extinct species tends to suggest a late Pleistocene age, but the small number of species makes even this age uncertain." The stratigraphic position, in several localities, of the 
travertine above gravel that probably is generally equivalent to the Sunbeam Formation also suggests a late Pleistocene age for much of the deposit. Eastward dips in the travertine-cemented breccia and sandstone in the Arbon quadrangle indicate that there has been renewed tectonic movement along the major fault after deposition of the travertine. This suggests that these deposits are somewhat older than flat-lying deposits west of the frontal fault of the Deep Creek Mountains.

\section{LOESS}

Calcareous silt, probably of eolian origin and of late Pleistocene and Holocene age, mantles Tertiary and Paleozoic rocks in the northeastern part of the Rockland quadrangle above an altitude of about 4,750 feet. Similar deposits, possibly of the same age, form an extensive mantle on the basaltic plain in the west half of the American Falls quadrangle (Carr and Trimble, 1963, p. G26). The loess in the Rockland quadrangle appears to be more than 100 feet thick locally but probably is much thinner in most places.

The loess is a light-tan poorly indurated uniform silt that is very well sorted and that contains about 20 -percent calcium carbonate. Loess stands in rather steep slopes in some places, owing mainly to surficial "case hardening" or induration.

No diagnostic fossils have been found in the loess. Loess in the west half of the American Falls quadrangle is younger than the Big Hole Basalt (Carr and Trimble, 1963, p. G26). The loess in the Rockland quadrangle may be of the same general Quaternary age, but an exact correlation has not been demonstrated. The loess may have been derived largely from the Raft Formation.

\section{SUNBEAM FORMATION}

Alluvial and colluvial deposits of silt and interstratified sand and gravel that are older than the American Falls Lake Beds were named the Sunbeam Formation (Carr and Trimble, 1963, p. G26). The Sunbeam in the area of this report is present only in the northern part of the Rockland quadrangle south of the Snake River. It lies below an altitude of 4,750 feet. The Sunbeam locally is at least 100 feet thick.

Most of the Sunbeam Formation in the Rockland quadrangle is unbedded to poorly bedded tan calcareous silt, and some fine-grained sand. Sand and gravel occur as lenses in the silt.

The Sunbeam, where fine grained, is difficult to distinguish from either the Raft Formation or the loess on the basis of lithology. The loess lacks bedding and lacks particles coarser than silt, whereas the Sunbeam commonly is at least faintly bedded and contains a few lenses of sand and gravel. The Raft Formation is distinguished from 
the Sunbeam mainly by the presence of calcareous nodules and, in some places, thick caliche, which are not found in the Sunbeam or in the loess.

As good exposures are scarce in this area, the limits of the Sunbeam were determined mainly by topography. A slight steepening in slope generally above an altitude of about 4,750 feet is common, and this marks the upper limit of the deposit. Silt in exposures above this altitude invariably lacks both bedding and particles coarser than silt. Silt in exposures below this altitude commonly shows some bedding and contains some sand and gravel. The contact between the loess and the Sunbeam, therefore, is drawn largely at the level of the 4,750-foot contour. West of Cold Creek, where the Sunbeam is in contact with the Raft Formation, the contact is drawn mostly on the basis of a poorly defined change in slope on the north side of the low north-facing dissected escarpment that borders the Snake River valley on the south. A single exposure of Raft Formation in a roadcut near the crest of the escarpment, in the NW ${ }^{1 / 4} \mathrm{NW}^{1 / 4}$ sec. 2 , T. 9 S., R. 30 E., suggests that the highest part of the escarpment is everywhere underlain by Raft.

A few species of land snails are present locally in the Sunbeam and, according to D. W. Taylor (written commun., 1959), "the absence of extinct species tends to suggest a late Pleistocene age, but the small number of species makes even this age uncertain." The Sunbeam is late Pleistocene age, but, as mapped, the Sunbeam probably includes deposits ranging in age from post-Raft to Holocene.

\section{CEDAR BUTTE BASALT}

The name Cedar Butte Basalt was applied by Stearns, Crandall, and Steward $(1938$, p. 69) to flows that crop out mainly along the northwest side of the Snake River in the Rockland quadrangle. The eastern limit of this basalt is in the $\mathrm{W}^{1 / 2}$ sec. 22 , T. 8 S., R. $30 \mathrm{E}$. The flows extend westward beyond the quadrangle. Stearns, Crandall, and Steward (1938) believed that two buttes, one of which was known as Cedar Butte (now called Janies Nipple), about 2 miles west of the Rockland quadrangle were the source of the Cedar Butte Basalt. The basalt is 25-100 feet thick.

The Cedar Butte is dense fresh-looking dark-gray basalt, commonly containing megascopic olivine, augite, and plagioclase laths. Diktytaxitic texture occurs locally. The basalt has a ropy surface with many pressure ridges as noted by Stearns and Isotoff (1956, $p$. 27).

The Cedar Butte Basalt overlies the Raft Formation and probably was responsible for damming of the Snake River that resulted in deposition of the American Falls Lake Beds. It is overlain by dune 
sand. Loess that mantles the Big Hole Basalt north of the area of sand dunes, in the American Falls quadrangle (Carr and Trimble, 1963), is not present on the Cedar Butte Basalt. The Cedar Butte is slightly older than the American Falls Lake Beds. Both probably are late Pleistocene in age.

\section{AMERICAN FALLS LAKE BEDS}

Stearns, Crandall, and Steward (1938, p. 69) named the American Falls Lake Beds. The term was applied to sediments deposited in a lake upstream from a lava dam formed by the Cedar Butte Basalt. We restricted the American Falls (Carr and Trimble, 1963, p. G28) to the upper part of the beds named by Stearns, who included in the formation beds older than the Cedar Butte. We also included at the base of the formation a gravel deposit that lies at an altitude of about 4,320 feet. The beds below this gravel, and older than the Cedar Butte Basalt, are referred to the Raft Formation. The American Falls Lake Beds are well exposed in bluffs that rim most of the American Falls Reservoir (in the American Falls quadrangle), and in the bluff along the west side of the Snake River in secs. 10 and 15, T. 8 S., R. 30 E., where a stratigraphic section of the American Falls Lake Beds and the underlying Raft (measured section C) was measured. The upper limit of the lake beds is at an altitude of about 4,400 feet, and the total thickness is about 80 feet.

In contrast to the Raft Formation, which is largely silt, the American Falls Lake Beds consist mainly of clay, with subordinate amounts of silt and sandy silt and, locally, abundant fine sand. Some of the clay is very diatomaceous, and some of the beds are calcareous. The composition of the formation (measured section $\mathrm{C}$ ) is uniform laterally, but some of the beds vary in thickness (Carr and Trimble, 1963, p. G28).

A molluscan fauna obtained from the American Falls Lake Beds (table 4) is considered to be late Pleistocene in age by D. W. Taylor (written commun., 1959). The assemblage suggests a cool wet climate.

The gravel at the base of the American Falls Lake Beds is locally fossiliferous and has yielded an abundant vertebrate and molluscan fauna. A collection of fragmentary vertebrate remains from near the SW. cor. sec. 15, T. 8 S., R. 30 E., in the Rockland quadrangle, includes mammoth, horse, camel, and bison, and is considered by G. E. Lewis, C. B. Schultz, and L. G. Tanner (written communs., $1958,1961)$ to be middle to late Pleistocene in age. The faunal association is comparable to similar materials of Yarmouth age from Sheridan County, Neb. Specimens of Bison (Gigantobison) latifrons, collected from the gravel along the American Falls Reservoir, were 
TABLE 4.-Mollusks from the American Falls Lake Beds, American Falls area, Idaho

\begin{tabular}{|c|c|c|c|c|c|c|c|c|}
\hline & \multicolumn{8}{|c|}{ Locality 1} \\
\hline & क्্口 & $\begin{array}{l}\text { D } \\
\underset{:}{*} \\
\text { స. }\end{array}$ & 㓠 & 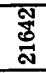 & $\begin{array}{l}\text { क्: } \\
\text { त् } \\
\end{array}$ & $\begin{array}{l}\text { 㞼 } \\
\text { స. }\end{array}$ & 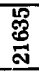 & 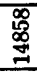 \\
\hline Freshwater clams: & & & & & & & & \\
\hline $\begin{array}{c}\text { Sphaerium striatinum (Lamarck) } \\
\text { indet. }\end{array}$ & $x$ & $x$ & $x$ & $x$ & $x$ & $\cdots$ & $x$ & ... \\
\hline Pisidium compressum Prime .... & $\cdots$ & $\cdots$ & $\cdots$ & $\cdots$ & $\cdots$ & & $x$ & $\cdots$ \\
\hline indet..$\ldots \ldots \ldots \ldots$ & $x$ & $\cdots$ & $\ldots$ & $\cdots$ & $x$ & $\cdots$ & $\cdots$ & $\cdots$ \\
\hline $\begin{array}{l}\text { Freshwater snails: } \\
\text { Valvata humeralis (Say) }\end{array}$ & $\ldots$ & &... & $\cdots$ & & $\cdots$ & $x$ & \\
\hline $\begin{array}{c}\text { Valvata humeralis (Say) } \\
\text { utahensis Call ...... }\end{array}$ & $x$ & $x$ & $x$ & $\cdots$ & $\cdots$ & $x$ & $x$ & $\cdots$ \\
\hline Lithoglyphus fuscus (Haldeman) & $\stackrel{x}{x}$ & $x_{x}^{x}$ & $\begin{array}{l}x \\
x\end{array}$ & $\begin{array}{l}\cdots \\
\ldots\end{array}$ & $\cdots$ & $\begin{array}{l}x \\
\ldots\end{array}$ & $\begin{array}{l}x \\
\ldots\end{array}$ & $\begin{array}{l}x \\
x\end{array}$ \\
\hline Stagnicola caperata (Say) . .......... & $\begin{array}{l}x \\
?\end{array}$ & $\begin{array}{l}x \\
\ldots\end{array}$ & $\begin{array}{l}x \\
x\end{array}$ & $\ldots$ & $\ldots$ & $x$ & $\ldots$ & … \\
\hline palustris (Müller) .............. & $\dot{x}$ & $\cdots$ & $x$ & $\ldots$ & $\ldots$ & $\ldots$ & $\cdots$ & $\cdots$ \\
\hline n. sp $\ldots \ldots \ldots \ldots \ldots \ldots \ldots \ldots \ldots$ & $\hat{?}$ & $\ldots$ & $x$ & $\ldots$ & $\ldots$ & $\ldots$ & $\ldots$ & $\ldots$ \\
\hline sp. a $\ldots \ldots \ldots \ldots \ldots \ldots$ & $\cdots$ & $\ldots$ & $x$ & $\ldots$ & $\ldots$ & $\ldots$ & $\cdots$ &.. \\
\hline sp. b $\ldots \ldots \ldots \ldots \ldots \ldots \ldots \ldots$ & $x$ & $\cdots$ & $\cdots$ & $\cdots$ & $\cdots$ & $\cdots$ & $\cdots$ & $\cdots$ \\
\hline $\begin{array}{c}\text { Gyraulus carcumstratus (Tryon). } \\
\text { parvus (Say) ............... }\end{array}$ & $\begin{array}{l}x \\
x\end{array}$ & $\begin{array}{l}\cdots \\
\cdots\end{array}$ & $\begin{array}{l}\cdots \\
\times\end{array}$ & $\begin{array}{l}\cdots \\
\cdots\end{array}$ & $\begin{array}{l}\cdots \\
\cdots\end{array}$ & 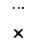 & $\cdots$ & $\begin{array}{l}\cdots \\
\cdots\end{array}$ \\
\hline Carinifex newberri (Lea). & $x$ & $\ldots$ & $x$ & $\ldots$ & $\ldots$ & $\ldots$ & $\ldots$ & \\
\hline Helisoma anceps (Menke) & $\begin{array}{l}x \\
x\end{array}$ & $\cdots$ & $\ldots$ & $\cdots$ & $\ldots$ & $\ldots$ & $\cdots$ & $\begin{array}{c}x \\
\cdots\end{array}$ \\
\hline subcrenatum (Carpenter) & $\cdots$ & $\ldots$ & $x$ & $\ldots$ & $\ldots$ & $\ldots$ & $\ldots$ & $\cdots$ \\
\hline $\begin{array}{l}\text { indet. ..................... } \\
\text { Prometus exacuous (Say) }\end{array}$ & $\cdots$ & $\cdots$ & $\cdots$ & $\cdots$ & $\ldots$ & $x$ & $x$ & $\ldots$ \\
\hline Promenetus exacuous (Say). & $x$ & $\ldots$ & $\cdots$ & $\cdots$ & $\ldots$ & $\cdots$ & .. & $\cdots$ \\
\hline umbilicatellus (Cockerell). & $x$ & $\ldots$ & $\ldots$ & $\ldots$ & $\ldots$ & $x$ & $x$ & $\ldots$ \\
\hline Ferrissia indet. . & $x$ & $\ldots$ & $\ldots$ & $\ldots$ & $\ldots$ & $\cdots$ & $\cdots$ & $\ldots$ \\
\hline $\begin{array}{l}\text { Physa indet. } \ldots \ldots \ldots \ldots \ldots \ldots \\
\text { Land snails: }\end{array}$ & $x$ & $\ldots$ & $\ldots$ & $\ldots$ & $\ldots$ & $\ldots$ & $x$ & \\
\hline Pupilla muscorum (Linnaeus). & $x$ & $\ldots$ & $\cdots$ & $\ldots$ & $\ldots$ & $\ldots$ & $\ldots$ & $\ldots$ \\
\hline $\begin{array}{l}\text { Vertigo gouldii (Binney) ...... } \\
\text { Vallonia cyclophorella }\end{array}$ & $x$ & $\ldots$ & $\ldots$ & $\ldots$ & $\ldots$ & $\ldots$ & $\ldots$ & ... \\
\hline 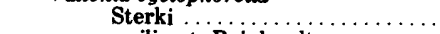 & $x$ & $\ldots$ & ... & $\ldots$ & $\ldots$ & $\ldots$ & $\ldots$ & $\cdots$ \\
\hline gracilicosta Reinhardt.. & $\hat{\ldots}$ & ... & $\cdots$ & $\ldots$ & $x$ & $\ldots$ & ... & $\ldots$ \\
\hline ff. Succinea & $x$ & $\ldots$ & $x$ & $\ldots$ & $\ldots$ & $\ldots$ & $\ldots$ & $\ldots$ \\
\hline Discus cronkhitei (Newcomb) & $x$ & $\ldots$ & $\ldots$ & $\cdots$ & $\ldots$ & $\cdots$ & $\ldots$ & .. \\
\hline $\begin{array}{l}\text { Retinella indet. . } \\
\text { Hawaiia minuscula (Binney) }\end{array}$ & $x$ & $\begin{array}{l}\cdots \\
\ldots\end{array}$ & $\ldots$ & $\begin{array}{l}\cdots \\
\ldots\end{array}$ & $\ldots$ & $\begin{array}{l}\cdots \\
\ldots\end{array}$ & $\begin{array}{l}\cdots \\
\ldots\end{array}$ & $\cdots$ \\
\hline Zonitoides arboreus (Say).. & $x$ & $\cdots$ & $\cdots$ & $\begin{array}{l}\cdots \\
\cdots\end{array}$ & $\ldots$ & $\ldots$ & $\ldots$ & $\cdots$ \\
\hline
\end{tabular}

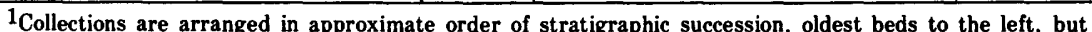
stratigraphic position of collection 21057 uncertain; it may be from a gravel (Michaud Gravel) younger than American Falls Lake Beds.

\section{SAMPLE LOCALITIES AND DESCRIPTIONS}

19169: Basal gravel, SE1/4 sec. 3, T. 6 S., R. 32 E.; edge of American Falls Reservoir.

21638: Basal gravel, NE $1 / 4 \mathrm{NW}^{1 / 4}$ sec. 15, T. 8 S., R. 30 E.; bluff on Snake River.

21057: Sand and gravel in lower part of formation or Michaud Gravel, $\mathrm{S}^{1 / 2} \mathrm{NE} 1 / 4$ sec. 3, T. 6 S., R. 32 E.; cliff at edge of American Falls Reservoir.

21642: About $15 \mathrm{ft}$ below prominent white blocky clay layer, $\mathrm{NE}^{1 / 4} \mathrm{SW}^{1 / 4} \mathrm{sec}$. 30, T. $7 \mathrm{~S}$., R. $31 \mathrm{E}$.; cliff at edge of American Falls Reservoir.

21639: About $15 \mathrm{ft}$ below prominent white blocky clay layer, NE $1 / 4 \mathrm{NW}^{1 / 4}$ sec. $15, \mathrm{~T} .8 \mathrm{~S}$., R. $30 \mathrm{E}$.; bluff on Snake River.

21643: $10 \mathrm{ft}$ below prominent white blocky clay layer, same location as 21642 .

21635: Below prominent white blocky clay layer; SE1/4 sec. 9, T. 6 S., R. 32 E.; cliff at edge of American Falls Reservoir.

14858: Prominent white blocky clay layer, SW1/4NE1/4 sec. 21, T. 6 S., R. 32 E.; cliff at edge of American Falls Reservoir.

described by Hopkins (1951). Hopkins, Bonnichsen, and Fortsch (1969) subsequently described a large collection of vertebrates from the locality in sec. 15, which included musk ox, ground sloth, pronghorn antelope, and many other forms not found in the original collection. It might be noted that there is disagreement on the age of the Great Plains occurrences of Bison latifrons. Hibbard $(1958$, p. 22) believed that this bison is of Sangamon age, whereas Schultz and Frankforter (in Schultz and 
others, 1951, table 1, p. 5) considered the giant bison to be indicative of probable Kansan age.

We previously concluded that the most reasonable age for the gravel at the base of the American Falls Lake Beds was Illinoian (Carr and Trimble, 1963, p. G29). The association of musk ox with this gravel (Hopkins and others, 1969) supports a periglacial environment during the deposition of this gravel. Occurrences along the mountain front areas in Colorado also indicate a pre-Bull Lake (Sangamon) age for Bison latifrons (Scott and Lindvall, 1970). A post-Bull Lake soil on younger flood deposits overlying the American Falls Lake Beds further indicates an early, or pre-Bull Lake, age for the lower gravel and the overlying part of the American Falls Lake Beds.

A radiocarbon date (W-929) for a layer of peat about 1 foot thick in the upper part of the American Falls Lake Beds in the Michaud quadrangle is $>42,000$ years B.P. (before present). The peat layer was exposed at an altitude of 4,385 feet in an excavation for a pipeline in the $\mathrm{SE}^{1 / 4} \mathrm{SW}^{1 / 4}$ sec. 36, T. $5 \mathrm{~S}$., R. $33 \mathrm{E}$. The peat is 13 feet below the top of the American Falls Lake Beds.

\section{ABERDEEN TERRACE DEPOSITS}

A terrace surface widely developed on both sides of American Falls Reservoir in the American Falls and Michaud quadrangles was named the Aberdeen terrace by agronomic soil scientists (Poulson and others, 1943, p. 5). This terrace, underlain by clay, silt, sand, and local sparse gravel, extends into the Rockland quadrangle on both sides of the Snake River. Two other terraces, the Grandview and the Sterling, that are also present in the American Falls quadrangle do not extend into the Rockland quadrangle. Scarps that mark the margins of the Aberdeen terrace in the American Falls quadrangle (Carr and Trimble, 1963, p. G31) and in the Michaud quadrangle are not well developed in the Rockland quadrangle. The base of the scarp at the back of the terrace north of this area is at about 4,420 feet in altitude, and that at the front is about 4,390 feet. The terrace surface, therefore, is almost flat and is about 4,400 feet in altitude. The terrace deposits north of the Snake River rest on the American Falls Lake Beds, but south of the river they are underlain by Tertiary rocks and by the Little Creek and Raft Formations. The terrace deposits probably are 5-10 feet thick.

The Aberdeen terrace deposits are poorly exposed in the Rockland quadrangle but no doubt are much like those west of the American Falls Reservoir, in the American Falls quadrangle. There, the front part of the terrace consists mainly of fluvial crossbedded sand, including a thin layer of pebbles at the base. At other places (mostly 
at the back of the terrace), the deposits are silt or parallel-bedded fine sand, silt, and clay.

The Aberdeen terrace deposits contain a few mollusks of late Pleistocene age. A radiocarbon age (W-731) (Rubin and Alexander, 1960, p. 158) for mollusk shells from the fore part of the Aberdeen terrace in the American Falls quadrangle is 29,700 $\pm 1,000$ years B.P.

\section{BOULDER BARS}

Large bars composed of huge boulders block the mouths of spillways marginal to the Snake River canyon and form boulder trains extending downriver from rock promontories on the northwest side of the Snake River in secs. 29 and 31, T. 8 S., R. 30 E. The boulder bars are all above an altitude of 4,250 feet, and most are above 4,300 feet. The boulders are mainly Cedar Butte Basalt and are as much as 20 feet in diameter but more commonly are 5-6 feet in diameter. Some of the boulders are subangular to subrounded. A few isolated boulders as much as $\mathbf{1 0}$ feet in diameter are found south of the Snake River, north of the highway between Massacre Rocks and the viewpoint in the $\mathrm{SW}^{1 / 4} \mathrm{SW}^{1 / 4}$ sec. 28 , T. $8 \mathrm{~S}$., R. $30 \mathrm{E}$.

The boulder bars probably were emplaced in late Pleistocene time, after the formation of the Aberdeen terrace. (See discussion under "Geologic History".)

\section{OLDER ALLUVIUM}

Alluvial deposits, mainly of Pleistocene age that cannot be confidently referred to a specific terrace deposit are mapped as older alluvium undifferentiated. This unit, which occurs south of the Snake River, formed during a period of downcutting by the Snake River after the deposition of the Aberdeen terrace level.

The older alluvium is mainly gravel that probably has been reworked from older deposits, perhaps originally from the Michaud Gravel (Carr and Trimble, 1963, p. G29, G32). Locally, the older alluvium contains abundant angular fragments from the Walcott Tuff, but most of the gravel is Paleozoic chert, quartzite, and carbonate rock.

Vertebrate and molluscan faunas of late Pleistocene age occur in the older alluvium. The mollusks are indistinguishable from those in other upper Pleistocene deposits. Gazin (1935) described a varied collection of vertebrates from the older alluvium at the east end of the American Falls Dam, in the American Falls quadrangle.

Near the west edge of the Rockland quadrangle, about 1 mile upstream from the mouth of Rock Creek, an abandoned channel of Rock Creek has been filled with gravel 50-100 feet thick that is mapped as older alluvium. The gravel is composed mainly of 
Paleozoic quartzite and limestone. This deposit is probably of late Pleistocene age and may have been laid down during a spillover of the Pleistocene American Falls lake across the dam of Cedar Butte Basalt.

\section{DUNE SAND}

Dune sands overlies the Big Hole Basalt, Cedar Butte Basalt, American Falls Lake Beds, and Aberdeen terrace deposits in a northeast-trending belt north of the Snake River. It also occupies a channeled area in the vicinity of Eagle Rock, and it caps a horseshoe-shaped mesa about three-quarters of a mile southwest of Eagle Rock.

The sand is mainly quartz but includes a few basalt fragments. Low areas between the dunes are floored by pebbly sand that suggests fluvial deposits. The dune sand probably was derived from fluvial deposits of late Pleistocene age. The dunes are still active and are, therefore, of Holocene age.

\section{YOUNGER ALLUVIUM}

Alluvial deposits of Holocene age cover the bottom of the valleys of Rock and Bannock Creeks and some of their tributaries and form islands and bars in and along the Snake River. The younger alluvium is mainly sand and gravel along the Snake River, but it is sand, silt, and clay in the smaller drainage courses. Much of the younger alluvium is in bands too narrow to show at the scale of the map.

\section{PETROLOGY OF THE IGNEOUS ROCKS}

Mineralogic details obtained from microscopic examination of the igneous rocks are supplemented by complete chemical analyses and spectrographic determinations of the trace elements. The Tertiary basaltic rocks are chemically different from the younger basalt. The chemistry of the silicic rocks is remarkably uniform.

\section{PETROGRAPHY}

\section{STARLIGHT FORMATION}

A variety of volcanic materials is present in the Starlight Formation. The following descriptions are given by general rock types. Percentages of constituents given are mainly visual estimates.

Shards from samples of rhyolitic tuff in the Starlight Formation were examined under the microscope. Shapes of the glass fragments range widely from platy fragments with nearly rectangular borders, to needle shaped, to sharply curved. No relation of shard shape to stratigraphic position was noted. In many samples the shards were coated with clay or opal and were pitted and frosted. Several 
samples, mainly from the very friable incoherent beds, contained unaltered shards that required little cleaning for analysis. Others were found to be in all stages of devitrification or recrystallization. The refractive index was measured on several of the freshest glasses, and it was found to be consistently very near 1.50; nearly all were between 1.495 and 1.505. In a few samples, brownish andesitic or basaltic shards, with a refractive index about 1.54 or more, were mixed with rhyolitic shards. Brown or dark-gray color was found to be an unreliable indication of composition, however, as some dark-brown shards were rhyolitic. In Rockland Valley a few lenses of brown welded to partially welded tuff, which probably are latitic, may be from the edge of a bed of latitic welded tuff that extends into the Raft River valley west of the Sublett Range.

Tuff beds, particularly in the upper member of the Starlight, contain many small ash pellets which have a thin outer indurated skin and an interior of ash that is distinctly finer grained than the ash on the exterior of the pellets. These pellets commonly occur in very well bedded tuffs.

The heavy minerals of selected tuff samples were examined. The results are not conclusive, but they suggest that differences in the mineral suites might be useful for correlation within the Starlight Formation and within the volcanic rocks immediately overlying it. The distribution, summarized in table 5, is based on from 3 to 10 samples per unit. Analysis of more samples would be required to firmly establish the variations in distribution of heavy minerals. The lower part of the lower member of the Starlight contains only zircon, ilmenite, and magnetite. Moreover, heavy minerals commonly are very scarce in the lower member of the Starlight, as compared with

TABLE 5.-Distribution of some heavy minerals in the rhyolitic Tertiary tuffs of the American Falls region, Idaho

\begin{tabular}{|c|c|c|c|c|c|}
\hline \multirow[b]{2}{*}{ Mineral } & \multirow{2}{*}{$\begin{array}{l}\text { Walcott } \\
\text { Tuff }^{1}\end{array}$} & \multirow{2}{*}{$\begin{array}{c}\text { Neeley } \\
\text { Formation }\end{array}$} & \multicolumn{3}{|c|}{ Starlight Formation } \\
\hline & & & $\begin{array}{c}\text { Upper } \\
\text { member }\end{array}$ & $\begin{array}{l}\text { Tuff of } \\
\text { Arbon } \\
\text { Valley }\end{array}$ & $\begin{array}{l}\text { Lower } \\
\text { member }\end{array}$ \\
\hline Orthopyroxene ... & $\mathbf{x}$ & $\mathbf{x}$ & $\mathbf{x}$ & $\mathbf{x}$ & $\cdots$ \\
\hline Biotite . . . . . . . & $\ldots$ & $\ldots$ & $\ldots$ & $\mathbf{x}$ & $\ldots$ \\
\hline Hornblende . & .. & $\mathbf{x}$ & $\mathbf{x}$ & $\mathbf{x}$ & $\cdots$ \\
\hline Oxyhornblende .... & $\ldots$ & $\mathbf{x}$ & . & $\mathbf{x}$ & $\ldots$ \\
\hline Clinopyroxene. & $\mathbf{x}$ & $\mathbf{x}$ & $\mathbf{x}$ & $\mathbf{x}$ & $\cdots$ \\
\hline Zircon $\ldots \ldots \ldots \ldots$ & $\mathbf{x}$ & $\mathbf{x}$ & $\mathbf{x}$ & $\mathbf{x}$ & $\mathbf{x}$ \\
\hline Ilmenite & $\mathbf{x}$ & $\mathbf{x}$ & $\mathbf{x}$ & $\mathbf{x}$ & $\mathbf{x}$ \\
\hline Magnetite . . . . . . . . & $\mathbf{x}$ & $\mathbf{x}$ & $\mathbf{x}$ & $\mathrm{x}$ & $\mathbf{x}$ \\
\hline Topaz (?) . & , & $\ldots$ & $\ldots$ & $\mathbf{x}$ & $\ldots$ \\
\hline Sphene. & . & . . & $\ldots$ & $\mathbf{x}$ & $\ldots$ \\
\hline
\end{tabular}

1 Bedded unwelded lower part.

2 includes about $200 \mathrm{ft}$ of marl and tuff beds immediately below the tuff of Arbon Valley. 
their abundance in the overlying tuffs that were sampled. Other noteworthy features of the heavy-mineral distribution are the lack of hornblende and oxyhornblende in the Walcott Tuff and the lack of oxyhornblende in the upper member of the Starlight.

Several types of basalts are represented in the samples studied from the lower member of the Starlight Formation, including three general types of porphyritic flows. One, which occurs mainly in the Cold Creek Canyon area and as accidental ejecta in the basaltic tuff of Starlight Creek valley, has an ophitic texture that results in a spotted appearance upon weathering. The spots are irregular areas 1-3 mm across of fine-grained clinopyroxene, which constitutes $35-40$ percent of the rock. The clinopyroxene encloses a few large crystals of plagioclase $0.5-2.5 \mathrm{~mm}$ long. Plagioclase microlites constitute 35-40 percent of the rock. As much as 10-percent olivine, in euhedral crystals as much as $0.5 \mathrm{~mm}$ across, is scattered throughout the rock. As in all basalts in the Starlight Formation, the olivine is altered to some degree to brown iddingsite and other minerals. A few plates and grains of opaque minerals are present. Optically, each area of clinopyroxene extinguishes as a unit under crossed nicols, even though it appears to be made up of many tiny individual grains. The composition of the larger plagioclase crystals is about $\mathbf{A n} \mathbf{n}_{60-72}$, and they are not conspicuously twinned. The microlites, which average about $0.1 \mathrm{~mm}$ long, are slightly more sodic than the phenocrysts; one measurement of extinction angles gave $\mathrm{An}_{56}$.

The second type of porphyritic basalt in the Starlight is a rather thin flow that occurs within the lower part of basaltic tuff along the northwest slopes of Starlight Creek valley. The rock is subophitic to ophitic, containing tabular plagioclase phenocrysts 1-4 mm long partly enclosed by areas $0.5-2 \mathrm{~mm}$ across of anhedral clinopyroxene. Red-brown isotropic and anistropic alteration products fill many cavities between grains. Plagioclase totals about 60 percent of the rock. There is a complete size gradation from the larger crystals, which predominate, to those in the matrix, which average about 1 $\mathrm{mm}$ long. Composition of the plagioclase phenocrysts is An 60-80, that of the smaller laths is An 60-65. The pyroxene is grayish brown in thin section and has a relatively small optic angle, suggesting pigeonite.

A third type of porphyritic basalt, which is more widespread and which probably is gradational with typical nonporphyritic basalt, is characterized by an intergranular-intersertal texture, but a few specimens are ophitic, diabasic, or trachytic. Most commonly, the rock has 1- to 5-percent irregularly distributed rectangular plagioclase crystals, $1-4 \mathrm{~mm}$ long, and a few $1 \mathrm{~mm}$ olivine euhedra in a groundmass of plagioclase, olivine, pyroxene microlites, and glass. 
The glass forms as much as 12 percent of the rock, and total plagioclase averages about 50 percent of the rock. Plagioclase phenocrysts in different speciments ranged in composition from $\mathrm{An}_{35}$ to $\mathrm{An}_{75}$; the microlites, from $\mathrm{An}_{53}$ to $\mathrm{An}_{68}$. Optic angle in nearly all the olivine is very close to $90^{\circ}$, and all the mineral grains are at least partly altered. Rarely, olivine is absent; in a few specimens it constitutes as much as 30 percent of the rock. Nonpleochroic hypersthene microlites constituted as much as several percent of the rock in a few of the thin sections examined. Most of the pyroxene appears to be augite, but pigeonite may be present in some flows. Glassy interstitial material in some specimens had been partly altered to palagonite and other unidentified alteration products. Small opaque grains make up about 5 percent of the rock. The small amounts of hypersthene in these and other flows of the Starlight are perhaps due to reaction of olivine with the liquid that crystallized later to form the groundmass. A few flows contain sufficient sodic feldspar and sufficient $\mathrm{SiO}_{2}$ (49-53 percent of the rock) to be classified as basaltic andesite.

The remaining basalts of the lower member of the Starlight (which in volume are at least equal to the total of all the other flows in both quadrangles) are much the same as the third type of porphyritic basalt; the only prominent difference is the absence of phenocrysts.

One thin section of the basaltic tuff in the northwestern part of the Arbon quadrangle was examined. Under the microscope it is seen to be composed of 90-percent fragments of very vesicular light-grayish-green basaltic glass (refractive index $>1.54$ ), 8-percent small fragments of olivine and plagioclase, and 2-percent small lithic fragments, inlcuding basalt and quartzite. In some specimens examined only megascopically, the tuff contained lenses of rhyolitic tuff or a few rhyolitic glass fragments.

A large, petrographically unusual silicic porphyry dike intrudes the lower member of the Starlight Formation near the north edge of the Arbon quadrangle (pl. 1). Many features indicate that this dike is rhyolite that was contaminated with basaltic magma during intrusion. Five thin sections of the rock were examined-one of a basalt "inclusion," and four showing textural variations in the dike. The porphyritic dike rock consists of 20- to 40-percent phenocrysts, as much as one-half inch across, of quartz (5-15 percent), sanidine (2-5 percent), oligoclase-labradorite (10-25 percent), and 8- to 20-percent small crystals of several minerals, including augite (2-5 percent), hypersthene (4-6 percent), biotite (2-8 percent), and opaque minerals (1-2 percent). The groundmass is silicic glass that contains microlites of alkali feldspar. In some places there are vaguely bounded areas of basaltic texture and mineralogy. The 
phenocrysts show much evidence of disequilibrium. Some of the quartz is anhedral and has a ring, or corona, of clinopyroxene. The plagioclase is zoned in some places, from labradorite to andesine; commonly, it has an area of "wormy" or remelted texture, surrounded by a clear rim of more alkalic feldspar. In some crystals only the core is "wormy," suggesting that the crystal was zoned in reverse; in others, only the rim has melted, and the remainder is unaffected. The biotite evidently reacted in places with the glass, forming wide borders of magnetite around the biotite. Similar textures in some rocks in Yellowstone National Park were described by Wilcox (1944), who ascribed them to contamination through mixing of basic and silicic magmas during emplacement. He pointed out, among other things, the impossibility of getting quartz xenocrysts inside what appear to have been solid basalt xenoliths contained in silicic rocks. Such xenocrysts-quartz crystals with coronas of pyroxene and partially remelted feldspar-are present in the basalt "xenoliths" of the dike in the Arbon quadrangle.

The middle member of the Starlight Formation is composed of a widespread ash-flow tuff, the tuff of Arbon Valley, and, locally, by other ash-flow tuffs that overlie it.

Table 6 shows the distribution of minerals in the upper part of the tuff of Arbon Valley. Most of the larger crystals in the tuff are fragmental and commonly embayed, although well-formed bypyramidal quartz crystals are very common. Some of the quartz is smoky. Average size of the crystals is about $0.5 \mathrm{~mm}$, although a complete size range exists from submicroscopic to $2 \mathrm{~mm}$. Plagioclase ranges in composition from $\mathrm{An}_{20}$ to $\mathrm{An}_{50}$; the average is probably near An 30. Sanidine occurs as broken subhedra, and biotite as greenish-brown flakes, some of which have been bent. Biotite is everywhere present, although the amount is very small in some specimens. Pyroxene, found to be pigeonite in a few specimens, is the only other material that forms as much as 1 percent of the rock.

The matrix of the rock is composed of glass shards, lithic fragments, including fragments of devitrified pumice, and accessory minerals, including pigeonite, ferroaugite, hypersthene, hornblende, zircon, magnetite, ilmenite, and others. All but pigeonite are present in only trace amounts. In all specimens pumiceous texture can be detected by careful microscopic examination. The sparse small pumice fragments contain cristobalite and alkali feldspar. Shards in the matrix are mostly devitrified. They generally are well alined as if by flowage, but they have fairly sharp corners and are not greatly compressed. Stretched or collapsed vesicles are present in some specimens. One measurement on a fairly fresh specimen gave a refractive index of about 1.51 for the glass in the groundmass. 
T.ABLE 6.-Average and range in phenocryst composition in the upper part of the tuff of Arbon Valley

[Data, based on 14 samples, are in percent]

\begin{tabular}{lccccr}
\hline & Quartz & Sanidine & Plagioclase & Biotite & Total \\
\hline Average............ & 10 & 10 & 7 & 2 & 130 \\
Range............. & $2-25$ & $5-17$ & $0-15$ & $1-8$ & $<15-45$
\end{tabular}

$1_{\text {Includes accessory minerals not given in table. }}$

Glassy welded tuffs of the middle member that overlie the tuff of Arbon Valley at a few places in the northwest corner of the Arbon and northeast corner of the Rockland quadrangle range from black obsidian to grayish-brown rhyolitic tuff that contain about 10 percent small crystals and locally numerous pumice fragments. Most of the rock is composed of welded shards. The texture is vermiform, but not extremely so. The shards are collapsed and well alined. The crystals consist of quartz, sanidine, sodic plagioclase, and scarce clinopyroxene. Biotite is absent.

Most of the tuff of the upper member of the Starlight is like that of the lower member. A thin brick-red welded tuff containing black obsidian nodules occurs locally in the upper member of the Starlight. This tuff is probably not more than 10 feet thick and is rarely exposed, owing to its occurrence between basalt flows. The rock has an eutaxitic texture and contains a few small crystals of quartz and sodic plagioclase.

\section{NEELEY FORMATION}

Most of the Neeley Formation is an impure tuff that contains much clay and silt and some sand, as well as rounded lumps of pumice, manganiferous calcite nodules, and small lenses of gravel. Rhyolitic shards in the tuff are iron stained, frosted, and somewhat worn by transport. Rarely, a few glass fragments more basic than rhyolite are present. Heavy minerals are fairly abundant in some beds. Along and near the Snake River, the upper few feet of the Neeley is a uniform bed composed of 70-85 percent of very small flat rhyolitic shards having a refractive index of about 1.495 . The rest of this part of the tuff consists of a few heavy minerals and a little quartz and feldspar.

\section{WALCOTT TUFF}

The Walcott Tuff is an unusually thin and uniform welded tuff that seems to have required very high temperatures during its deposition, but its means of emplacement is not yet fully understood. The ash-fall and welded ash-flow parts of the Walcott Tuff were studied in some detail, but the upper, nonwelded, rarely preserved tuff unit is available for study only in a very few poor outcrops. 
Tuff similar to the Walcott has been described by Mansfield and Ross (1935) from near Idaho Falls. Stearns and Isotoff (1956, p. 32-33) also described the Walcott briefly. Some additional details are given here.

The well-bedded rhyolitic ash, or lower part, of the Walcott is composed mainly of curved to flat or straight frosted and colorless shards with a refractive index of between 1.495 and 1.50. These glass fragments are arranged in thin graded beds of uniform thickness. Most of the shards are less than $1 \mathrm{~mm}$ across. A few heavy minerals (table 5), quartz, and alkali feldspar grains are present. The rarely preserved uppermost unit of the Walcott is similar in composition to the lower tuff but lacks bedding.

In thin section, the ash-flow tuff part of the Walcott shows a rather uniform texture. It has an eutaxitic to wormlike texture throughout, almost identical to that described by Mansfield and Ross (1935) for a similar rock in the Ammon area, about 70 miles to the northeast. The individual shard particles have no sharp corners, but many are Y-shaped and are squeezed, fused, and alined such that they conform to one another. A few of the shards were evidently bubble-shaped before fusion. The glass is dark brown to clear, has a refractive index of about 1.495, and is fairly fresh in most specimens, but it is highly devitrified in a few. Spherulites are common in the more devitrified specimens. Crystals, which generally make up less than 5 percent of the tuff, include oligoclase, sanidine, hypersthene, augite, and a little magnetite; no quartz was found.

Several thin sections were examined of the spherulitic phase of the ash-flow part of the Walcott, which is well developed in the Eagle Rock area and at the west side of American Falls. This is a purplishgray lithophysal rock that has an eutaxitic texture even though it is highly devitrified. The shards are greatly compacted but tend to be twisted in places, as if disturbed by flowage. In a typical specimen, devitrification tends to follow shard outlines, but there are many circular spherulitic devitrified areas that average about $1 \mathrm{~mm}$ across. The spherulites appear to be composed mainly of radially arranged fibrous needles of potash feldspar.

Smith $(1960$, p. 152) discussed crystallization in silicic welded tuffs, pointing out three main types-crystallization by devitrification, vapor-phase crystallization, and granophyric crystallization. In the samples we studied, the minor crystallization of the Walcott apparently was almost entirely by devitrification, which resulted in the formation of spherulites and slight crystallization around borders of the shards. Little pore space is available for vapor-phase crystallization, except possibly in locally developed lithophysae, where microcrystalline quartz, opal, and 
potash feldspar have been noted. Granophyric crystallization was not detected.

Previously, we (Carr and Trimble, 1963) agreed with Mansfield and Ross (1935, p. 310) that the Walcott Tuff and a tuff near Ammon (not far from Idaho Falls) might be the same. The chemistry of the welded tuffs of the two areas is virtually identical. Several facts now suggest, however, that the obsidian tuff near Ammon described by Mansfield and Ross may not be the same flow as the Walcott. First, many of the shards in the unwelded bedded tuff in the lower part of the tuff near Ammon are extensively devitrified and are thin and needle shaped, whereas the shards of the lower bedded-tuff member of the Walcott are normally unaltered and tend to be flat or curved. Second, heavy minerals in the two bedded tuffs also differ - the tuff near Ammon contains mostly magnetite and a little ilmenite and zircon, whereas the lower member of the Walcott contains more, and a greater variety of, heavy minerals. (See table 5.) Glass from both members of the Walcott has a refractive index distinctly below 1.50 , whereas glass from the tuff near Ammon has an index slightly above 1.50; this difference could easily be accounted for by difference in the degree of hydration, however. It is possible, of course, that the bedded tuffs of the two areas had different eruptive sources, but similarity of the chemistry of the welded tuffs in the two areas strongly suggests that they are both contemporaneous and from the same source.

\section{LITTLE CREEK FORMATION}

Only a few samples from the Little Creek Formation were studied in detail. One from near the base of the formation at the viewpoint, in the $\mathrm{SE}^{1 / 4}$ sec. 29, T. $8 \mathrm{~S}$., R. $30 \mathrm{E}$., is a fine- to medium-grained laminated tuffaceous sandstone. Some of the laminae are slightly calcareous. The sand consists of quartz, sanidine, plagioclase, and a few pyroxene and olivine grains, together with several kinds of glass fragments. Palagonite makes up perhaps 10 percent of the rock. The larger glass fragments are basaltic, and many show partial or complete alteration to yellow palagonite. A second type of glass is clear, is vesicular, shows little alteration, and probably is rhyolitic. The matrix is clay. This sample contained no diatoms, although some other samples from the formation-especially those from Ferry Hollow, in the American Falls quadrangle-contained numerous diatoms. A similar rock from just beneath basalt in Rockland Valley east of Rock Creek is a grayish-tan tuff containing many lithic fragments of dark basaltic glass, white pumice, clear shards, and a few crystals in a clayey matrix. Microscope study showed the presence of a few pieces of Walcott welded tuff, fragments of diatomite and marl, abundant cellular grayish-green basaltic glass, a 
few crystals of pyroxene, sanidine, and plagioclase, and many rhyolitic glass fragments and pumice bundles. The matrix is weakly birefringent clay containing numerous diatoms. Other samples contain abundant zircon and olivine.

Rocks exposed near the mouth of Little Creek in the SW $1 / 4 \mathrm{SE}^{1 / 4}$ sec. 15, T. 8 S., R. 30 E., demonstrate the virtual contemporaneity of part of the Little Creek with part of the Massacre Volcanics erupted from the Eagle Rock vent, though in other places an angular unconformity separates the two formations. Moreover, both the basalt of the Eagle Rock vent and the basalt of Rockland Valley are present, and the latter flowed over the former, possibly before the basalt from the Eagle Rock vent had cooled.

A detailed petrographic description of the rocks in this outcrop follows.

SECTiON A.-Basalts of the Massacre Volcanics from Rockland Valley and from Eagle Rock, and part of the Little Creek Formation in a small gully in the $S W^{1 / 4} S E^{1 / 4}$ sec. $15, T .8 S$., R. 30 E., Rockland quadrangle, Idaho

[Includes petrographic description]

Top of outcrop.

Massacre Volcanics (part):

Basalt from Rockland Valley:

6. Basalt, dark-gray, fresh-looking, diktytaxitic, intergranular to subophitic; contains 40-percent plagioclase $\left(A n_{50-60}\right)$, 35-percent augite, 20-percent olivine, and 5-percent opaque grains. Crystals average $0.1-0.2 \mathrm{~mm}$ across, but some projecting into vesicles are $0.5-2 \mathrm{~mm}$ across. Lower contact fairly sharp $\ldots \ldots \ldots \ldots \ldots \ldots$ Basalt from Eagle Rock:

5. Basalt, dark-gray, platy, fine-grained, dense; a few small vesicles in upper part to very vesicular in lower part. Texture is fine grained intergranular but with scattered pyroclasts and foreign crystals, particularly in lower part, and small rosettes of plagioclase. Contains about 20-percent plagioclase $\left(\mathrm{An}_{60}\right)$ and 8-percent olivine as larger crystals $(0.2-1 \mathrm{~mm}$ across) with microlites of plagioclase, clinopyroxene, and opaque minerals as fine-grained groundmass which is partly glassy; grades down into tuff by increasing the

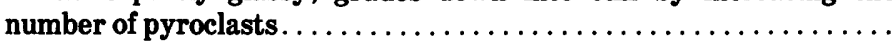

Little Creek Formation (part):

4. Basaltic tuff, platy, dark-gray; finely vesicular, with numerous vesicular pyroclasts of similar glassy basalt, some light-colored silicic pyroclasts, and a few crystals, mostly of basic plagioclase. Fragments contain numerous very small microlites of plagioclase

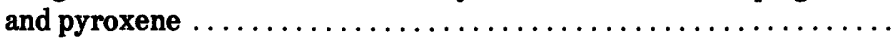

3. Basaltic tuff; similar to overlying unit, but more pyroclastic in texture and with considerable palagonite; contains 5-percent rhyolitic glass fragments, some of which are partly devitrified. . . . . . . . . . . .

2. Basaltic tuff, grayish-tan, moderately indurated. Consists of 10-percent small crystal fragments, which are mostly broken plagioclase with some olivine and pyroxene, a few with quartz and sanidine; 60-percent opaque basaltic highly vesicular glass that contains plagioclase and olivine microlites; 10 -percent rhyolitic pumice 
SECTION A.-Basalts of the Massacre Volcanics from Rockland Valley and from Eagle Rock, and part of the Little Creek Formation in a small gully in the $S W^{1 / 4} S^{1 / 4}$ sec. $15, T .8$ S., R. 30 E., Rockland Quadrangle, Idaho-Continued

Little Creek Formation (part)-Continued

2. Basaltic tuff-Continued

Thickness

fragments, which are clear to light brown; 20-percent light-brown to orange palagonite which has filled vesicles and replaced glass .....

1. Tuff, yellowish-gray to purplish, moderately indurated; composed of a mixture of black to dark-green frothy basaltic glass fragments and white to colorless rhyolitic shards and pumice, mostly one-eighth inch across; some unidentified lithic fragments and numerous broken crystals of olivine, calcic and alkalic feldspar, and quartz . .........

Total measured thickness of exposed rocks ............ $\quad \frac{4.0}{9.0}$

\section{MASSACRE VOLCANICS}

Nearly all tuff of the Massacre Volcanics is coarse-grained basaltic air-fall tuff that contains many lithic fragments. Many of the tuffs are cindery. Two distinctive types of basaltic rocks are recognized in the Massacre Volcanics. Basalt from the Eagle Rock vent differs markedly, both texturally and mineralogically, from basalt of the Massacre Rocks source vents and from that in Rockland Valley.

The basalt of the Eagle Rock vent is the oldest of the basalts of the Massacre Volcanics. Typically, it is a dense fine-grained basalt that has an intersertal to intergranular texture. Dots and rosettelike clusters of small plagioclase laths, 0.1-0.5 mm long, are scattered in a fine-grained partly glassy groundmass composed mostly of pale-green pyroxene and feldspar microlites in nearly equal amounts. The groundmass constitutes from 50 to as much as 87 percent of the rock. The plagioclase laths, which have a composition of An 52-62, constitute about 25 percent of the rock. The pyroxene, probably augite, is almost entirely in the groundmass. Olivine phenocrysts form less than 15 percent and commonly less than 5 percent of the rock.

Unit 5 in measured section A, from near the mouth of Little Creek, is thought to be basalt from the Eagle Rock vent. It contains quartz crystals, some with rings of clinopyroxene, and incipiently melted plagioclase feldspars, indicating a possible intermixing of rhyolitic and basaltic magmas, such as occurred in the formation of the silicic porphyry of the dike in the Starlight Formation in the Arbon quadrangle. (See p. 73-74.)

Many of the plagioclase laths in some flows and in a dike near Eagle Rock are corroded along their edges and are partially replaced along twinning planes, indicating incipient melting. Sparse quartz phenocrysts also are present in some samples. The quartz phenocrysts and the melted feldspars indicate that the basalt from the Eagle Rock vent is a contaminated rock. The chemical analyses 
of a basalt of Eagle Rock origin (sample No. 13, table 7) shows a higher content of silica and potash than is normal for rocks of similar age in this area, suggesting that this rock has picked up some silicic material.

Basalt of the Massacre Volcanics in Rockland Valley, both on Table Mountain and east of Rock Creek, is mainly subophitic to ophitic in texture, but some is intergranular and even intersertal. The basalt contains 35- to 45-percent plagioclase $\left(\mathrm{An}_{56-68}\right)$, 20- to 45-percent augite or pigeonite, 10 - to 20 -percent olivine, and 5- to 10-percent opaque minerals. Plagioclase laths range in length from 0.1 to 2.5 $\mathrm{mm}$ and average about $0.5 \mathrm{~mm}$. Locally, clusters of plagioclase laths are common. Olivine phenocrysts are large and abundant and are about the same size as the plagioclase phenocrysts. The olivine phenocrysts are anhedral or euhedral, and many have strong alteration rims of brown or orange-brown iddingsite. These rocks from Rockland Valley sources differ from those of the Eagle Rock vent mainly in their greater abundance of olivine and of augite or pigeonite phenocrysts; also basalts from Rockland Valley have a different texture than those from the Eagle Rock vent. Basalt of the Massacre Rocks vent shows no evidence of contamination by silicic material.

The basalt plugs and flows at Massacre Rocks are petrographically similar to the basalt of Rockland Valley, except that they are somewhat coarser grained and have a better developed diktytaxitic texture. Cavities form more than 15 percent of the rock in some places.

\section{BIG HOLE BASALT}

The Big Hole Basalt of the American Falls quadrangle characteristically has an intersertal texture and is composed of 35- to 45-percent plagioclase laths $\left(\mathrm{An}_{48-70}\right)$ and 15- to 25-percent euhedral olivine in a groundmass composed of fibrous, poorly crystallized pyroxene, glass, and magnetite. The groundmass forms from 15 to 50 percent of the rock, and magnetite may form as much as a third of the groundmass. In the Rockland quadrangle, however, samples of the Big Hole Basalt examined microscopically were subophitic and contained about 40-percent clinopyroxene in clots of crystals and in zones of crystals around the plagioclase, rather than as single crystals, as in the Cedar Butte Basalt. Obviously, basalts of different types originating at different vents are included in the Big Hole Basalt.

\section{CEDAR BUTTE BASALT}

The Cedar Butte Basalt is mostly ophitic to subophitic and, locally, intergranular or intersertal. Plagioclase laths (An 57-60), averaging 
about $0.5 \mathrm{~mm}$ in length, form $40-55$ percent of the rock. Augite or pigeonite constitutes 25-40 percent of the rock, and olivine constitutes 10-20 percent. Much of the pyroxene has a relatively low optic angle and probably is pigeonite. It occurs mostly as anhedral crystals $1-2 \mathrm{~mm}$ long. The olivine occurs mainly as euhedral or subhedral phenocrysts that are generally less than $2 \mathrm{~mm}$ long, although some are as much as $\mathbf{5 m}$ long.

\section{COMPOSITION OF THE BASALTIC ROCKS}

Chemical and spectrographic analyses of basalts of this area, given in tables 7 and 8 , show that the basalts of the Starlight Formation of Pliocene age are chemically different from all the younger basalts. The younger basalts, on the other hand, show chemical affinities with the basalts of the Snake River Group that were described by Powers (1960) as possibly constituting a clan. The ratio between $\mathrm{SiO}_{2}, \mathrm{MgO}$, and total iron in the Starlight basalt is closer to that in basalts of the Cascade Range in western Washington and Oregon than to the basalts of the Columbia River or Snake River Group plotted by Powers (1960).

The Starlight basalts compare closely with the "Central" type of basalt of Nockolds (1954, p. 1021). Nockolds' average of 56 analyses basalts of the "Central" type is included in table 7 for comparison. The basalts of this type contain more silica, alumina, and soda, and less magnesia, ferrous oxide, titania, and phosphate than most other basalts. These differences are clearly apparent when the average of the Starlight basalts, which probably are of the "Central" type, is compared with the average of the younger basalts. Nockolds indicated (1954, p. 1009) that the "Central" type commonly is found in association with more silicic rocks at volcanic centers, and this certainly is true of the Starlight basalts, which are interstratified with rhyolitic tuffs.

Powers showed that the Snake River basalts differ significantly in their chemistry from other basalts of the Northwestern United States. Three analyses of basalts of the Massacre Volcanics of this area (sample Nos. 6-8, table 7) were included in Powers' study. His Snake River basalts included only rocks younger than the Starlight Formation (H. A. Powers, oral commun., 1960). Powers found that generally the rocks of the Snake River valley are lower in silica than the basalts of the Columbia River Group or the basalts of the Cascade Range of Oregon and Washington, and that the silica content generally decreases as the ratio of iron to magnesia increases. This is opposite the normal trend of magmatic differentiation. Powers concluded that the Snake River basalts have a high degree of cosanguinity and may constitute a clan. 
TABLE 7.-Chemical analyses of basaltic

[Analysts: Elaine L. Munson and Dorothy F. Powers.

\begin{tabular}{|c|c|c|c|c|c|c|c|c|c|c|}
\hline \multirow[b]{2}{*}{$\begin{array}{l}\text { Sample No.... } \\
\text { Lab. No..... }\end{array}$} & \multicolumn{5}{|c|}{ Starlight Formation } & \multicolumn{5}{|c|}{$\begin{array}{l}\text { Massacre } \\
\text { Volcanics }\end{array}$} \\
\hline & $\begin{array}{c}1 \\
\text { F2667 } \\
\end{array}$ & $\begin{array}{c}2 \\
\text { E2249 } \\
\end{array}$ & $\begin{array}{c}3 \\
\text { F2666 } \\
\end{array}$ & $\begin{array}{c}24 \\
\text { F2663 } \\
\end{array}$ & $\begin{array}{c}25 \\
\text { H4490 } \\
\end{array}$ & $\begin{array}{c}26 \\
\text { E2245 } \\
\end{array}$ & $\begin{array}{c}27 \\
\text { E2246 } \\
\end{array}$ & $\begin{array}{c}28 \\
\text { E2247 } \\
\end{array}$ & $\begin{array}{c}9 \\
\text { F2662 } \\
\end{array}$ & $\begin{array}{c}10 \\
\text { F2668 } \\
\end{array}$ \\
\hline $\begin{array}{l}\mathrm{SiO}_{2} \ldots \ldots \ldots \ldots \\
\mathrm{Al}_{2} \mathrm{O}_{3} \ldots \ldots \ldots \\
\mathrm{Fe}_{2} \mathrm{O}_{3} \ldots \ldots \ldots \\
\mathrm{FeO} \ldots \ldots \ldots \\
\mathrm{MgO} \ldots \ldots \ldots\end{array}$ & $\begin{array}{r}50.05 \\
16.97 \\
4.66 \\
6.03 \\
5.05\end{array}$ & $\begin{array}{r}48.74 \\
18.23 \\
5.10 \\
5.41 \\
6.18\end{array}$ & $\begin{array}{r}49.62 \\
17.37 \\
3.24 \\
7.38 \\
6.40\end{array}$ & $\begin{array}{r}53.02 \\
15.90 \\
2.51 \\
6.92 \\
6.35\end{array}$ & $\begin{array}{r}52.48 \\
16.25 \\
3.09 \\
6.13 \\
6.22\end{array}$ & $\begin{array}{r}46.20 \\
17.13 \\
1.60 \\
10.53 \\
8.22\end{array}$ & $\begin{array}{r}46.31 \\
17.27 \\
1.94 \\
10.53 \\
8.29\end{array}$ & $\begin{array}{r}46.70 \\
15.93 \\
4.80 \\
8.11 \\
7.62\end{array}$ & \begin{tabular}{r|}
48.81 \\
16.37 \\
1.97 \\
8.56 \\
8.12
\end{tabular} & $\begin{array}{r}48.95 \\
15.51 \\
1.89 \\
10.04 \\
7.25\end{array}$ \\
\hline $\begin{array}{l}\mathrm{CaO}_{2} \\
\mathrm{Na}_{2} \mathrm{O} \\
\mathrm{K}_{2} \mathrm{O} \\
\mathrm{H}_{2} \mathrm{O}+ \\
\mathrm{H}_{2} \mathrm{O}-\end{array}$ & $\begin{array}{r}9.01 \\
3.10 \\
1.00 \\
.89 \\
1.23\end{array}$ & $\begin{array}{r}10.59 \\
2.54 \\
.45 \\
.47 \\
.60\end{array}$ & $\begin{array}{r}9.89 \\
2.78 \\
.69 \\
.53 \\
.47\end{array}$ & $\begin{array}{r}8.63 \\
2.75 \\
.84 \\
.55 \\
.60\end{array}$ & $\begin{array}{r}9.02 \\
2.43 \\
.85 \\
.62 \\
1.26\end{array}$ & $\begin{array}{r}10.61 \\
2.55 \\
.17 \\
.17 \\
.17\end{array}$ & $\begin{array}{r}10.36 \\
2.54 \\
.16 \\
.09 \\
.07\end{array}$ & $\begin{array}{r}10.63 \\
2.24 \\
.29 \\
.20 \\
.17\end{array}$ & $\begin{array}{r}11.25 \\
2.22 \\
.35 \\
.35 \\
.35\end{array}$ & $\begin{array}{r}10.26 \\
2.30 \\
.50 \\
.36 \\
.13\end{array}$ \\
\hline $\begin{array}{l}\mathrm{TiO}_{2} \\
\mathrm{P}_{2} \mathrm{O}_{5} \\
\mathrm{MnO}^{\mathrm{CO}_{2}} \\
\mathrm{~F} .\end{array}$ & $\begin{array}{r}1.26 \\
.34 \\
.16 \\
.13\end{array}$ & $\begin{array}{l}.92 \\
.20 \\
.17 \\
.16 \\
.02\end{array}$ & $\begin{array}{l}.96 \\
.21 \\
.18 \\
.16\end{array}$ & $\begin{array}{r}1.39 \\
.32 \\
.14 \\
.01\end{array}$ & $\begin{array}{r}1.12 \\
.21 \\
.15 \\
.03 \\
.02 \\
\end{array}$ & $\begin{array}{r}1.78 \\
.39 \\
.19 \\
.07 \\
.03 \\
\end{array}$ & $\begin{array}{r}1.74 \\
.38 \\
.19 \\
.01 \\
.03 \\
\end{array}$ & $\begin{array}{r}2.51 \\
.37 \\
.19 \\
.06 \\
.03 \\
\end{array}$ & $\begin{array}{r}1.41 \\
.22 \\
.18 \\
.13 \\
.02 \\
\end{array}$ & $\begin{array}{r}2.22 \\
.29 \\
.18 \\
.09 \\
.03 \\
\end{array}$ \\
\hline $\begin{array}{l}\text { Sub Total } \\
\text { Less } 0 \ldots \\
\text { Total .... }\end{array}$ & $\begin{array}{r}99.93 \\
.02 \\
99.91 \\
\end{array}$ & $\begin{array}{r}99.79 \\
.01 \\
99.78 \\
\end{array}$ & $\begin{array}{r}.01 \\
99.90 \\
\end{array}$ & $\begin{array}{r}99.97 \\
.02 \\
99.95 \\
\end{array}$ & $\begin{array}{r}99.88 \\
.01 \\
99.87 \\
\end{array}$ & $\begin{array}{r}99.81 \\
.01 \\
99.80 \\
\end{array}$ & $\begin{array}{r}99.91 \\
.01 \\
99.90 \\
\end{array}$ & $\begin{array}{r}99.85 \\
.01 \\
99.84 \\
\end{array}$ & $\begin{array}{r}100.31 \\
.01 \\
100.30 \\
\end{array}$ & $\begin{array}{r}100.00 \\
.01 \\
99.99 \\
\end{array}$ \\
\hline
\end{tabular}

1 Nockolds, 1954, p. 1021.

2 Each group of samples is probably from the same flow at different localities.

3 Average of three determinations.

\begin{tabular}{|c|c|}
\hline $\begin{array}{l}\text { No. Section } \\
\text { 1. SW } 1 / 4 \mathrm{SE}^{1 / 4} 24 \\
\text { 2. } \mathrm{NW}^{1 / 4} 35 \\
\text { 3. } \mathrm{SE}^{1 / 4} \mathrm{SW}^{1 / 4} 11 \\
\text { 4. } \mathrm{NE}^{1 / 4} \mathrm{SE}^{1 / 4} 32 \\
\text { 5. } \mathrm{SE}^{1 / 4} \mathrm{SE}^{1 / 4} 28\end{array}$ & $\begin{array}{l}T . S . \\
8 \\
8 \\
8 \\
7 \\
7\end{array}$ \\
\hline
\end{tabular}

SAMPLE LOCALITIES

\begin{tabular}{|c|c|c|c|c|c|}
\hline $\begin{array}{l}\text { Quadrangle } \\
\text { Rockland. } \\
\text { Do. } \\
\text { Do. }\end{array}$ & $\begin{array}{l}\text { No. } \\
10 . \\
11 . \\
12 .\end{array}$ & $\begin{array}{l}\quad \text { Section } \\
\text { SE }^{1 / 4} \text { NW }^{1 / 4} 32 \\
\text { SW }^{1 / 4} \text { NW }^{1 / 4} 32 \\
\text { NE }^{1 / 4} \text { NE }^{1 / 4} 6\end{array}$ & $\begin{array}{l}T . S . \\
8 \\
9\end{array}$ & $\begin{array}{l}R . E . \\
\mathbf{3 0} \\
\mathbf{3 0} \\
\mathbf{3 0}\end{array}$ & $\begin{array}{c}\text { Quadrangle } \\
\text { Rockland. } \\
\text { Do. } \\
\text { Do. }\end{array}$ \\
\hline $\begin{array}{c}\text { Michaud. } \\
\text { Do. }\end{array}$ & 13. & \multicolumn{4}{|c|}{$\begin{array}{l}\text { (Contaminated basalt from Eagle Rock vent (see } \\
\text { text), from same outcrop as No. 10.) }\end{array}$} \\
\hline $\begin{array}{l}\text { Rockland. } \\
\text { Do. } \\
\text { merican Falls. } \\
\text { Rockland. }\end{array}$ & $\begin{array}{l}14 . \\
15 . \\
16 . \\
17 . \\
18 .\end{array}$ & $\begin{array}{l}\mathrm{SE}^{1 / 4} \mathrm{SW}^{1 / 4} 27 \\
\mathrm{SW}^{1 / 4} \mathrm{NE}^{1 / 4} 30 \\
\mathrm{Near}^{2} \text { center } 16 \\
\mathrm{NE}^{1 / 4} 21 \\
\mathrm{SW}^{1 / 4} \mathrm{NW}^{1 / 4} 29\end{array}$ & $\begin{array}{l}7 \\
5 \\
8 \\
8 \\
8\end{array}$ & $\begin{array}{l}30 \\
\mathbf{3 2} \\
30 \\
30 \\
30\end{array}$ & $\begin{array}{c}\text { American Falls. } \\
\text { Do. } \\
\text { Rockland. } \\
\text { Do. } \\
\text { Do. }\end{array}$ \\
\hline
\end{tabular}

The basalts of the Massacre Volcanics, the Big Hole Basalt, and the Cedar Butte Basalt not only are generally similar to each other but also are chemically similar to other basalts of the Snake River valley described by Powers. In many respects they compare closely with a normal alkali basalt, for which Nockolds' average $(1954, \mathrm{p}$. 1021 ) is given in table 7.

Many basalts of the western Snake River Plain contain relatively high amounts of $\mathrm{P}_{2} \mathrm{O}_{5}$ (H. A. Powers, written commun. 1960), more than is common in the basalt of the Columbia River Group, for example. This is also true of the younger basalts of the Rockland-Arbon area.

The trace elements in the basalts of this area are shown in table 8. Some slight differences between the trace elements of the basalts in 
rocks of the American Falls area, Idaho

Leaders $(. .$.$) indicate not given in Nockold's tables]$

\begin{tabular}{|c|c|c|c|c|c|c|c|c|c|c|c|c|}
\hline & $\begin{array}{l}\text { Massac } \\
\text { Volcani }\end{array}$ & & Big & Hole Ba: & & Cedar & Butte & 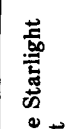 & 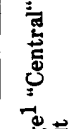 & 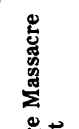 & 总 & 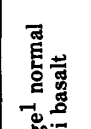 \\
\hline $\begin{array}{c}11 \\
\text { F2670 } \\
\end{array}$ & $\begin{array}{c}12 \\
\text { F2671 } \\
\end{array}$ & $\begin{array}{c}13 \\
\text { F2669 } \\
\end{array}$ & $\begin{array}{c}14 \\
\text { F2664 } \\
\end{array}$ & $\begin{array}{c}15 \\
\text { F2665 }\end{array}$ & $\begin{array}{c}16 \\
\text { H4488 }\end{array}$ & $\begin{array}{c}217 \\
\mathrm{H} 4486\end{array}$ & $\begin{array}{c}218 \\
\text { H4487 }\end{array}$ & 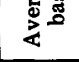 & 通 & 起 & 40 & z \\
\hline 46.90 & 47.78 & 52.12 & 46.08 & 46.60 & 46.50 & 46.25 & 46.83 & 50.78 & 51.33 & 47.38 & 46.45 & 45.78 \\
\hline 14.68 & 14.84 & 16.57 & 15.21 & 15.72 & 15.28 & 15.26 & 15.27 & 16.94 & 18.04 & 15.96 & 15.35 & 14.64 \\
\hline 2.34 & 2.41 & 1.27 & 1.36 & 4.44 & 1.42 & 5.32 & 1.77 & 3.72 & 3.40 & 2.42 & 2.86 & 3.16 \\
\hline 11.11 & 11.13 & 8.47 & 11.01 & 8.29 & 10.87 & 7.34 & 11.05 & 6.37 & 5.70 & 10.00 & 9.71 & 8.73 \\
\hline 7.27 & 6.55 & 6.67 & 9.25 & 8.37 & 9.61 & 9.02 & 8.13 & 6.04 & 6.01 & 7.62 & 8.88 & 9.39 \\
\hline 10.61 & 10.71 & 9.39 & 10.90 & 9.99 & 10.79 & 10.57 & 10.17 & 9.43 & 10.07 & 10.63 & 10.48 & 10.74 \\
\hline 2.21 & 2.32 & 2.31 & 2.38 & 2.50 & 2.24 & 2.30 & 32.42 & 2.72 & 2.76 & 2.34 & 2.37 & 2.63 \\
\hline .42 & 44 & .77 & .42 & .55 & .41 & .48 & 3.77 & .77 & .82 & .33 & .53 & .95 \\
\hline .35 & .12 & .47 & .29 & .36 & .30 & .29 & .17 & .61 & .45 & .23 & .28 & .76 \\
\hline 18 & & .36 & .09 & .13 & .10 & .18 & .06 & .93 & & .16 & .11 & \\
\hline 3.01 & 3.24 & 1.14 & 1.92 & 2.31 & 1.90 & 2.16 & 2.49 & 1.13 & 1.10 & 1.99 & 2.15 & 2.63 \\
\hline .42 & .46 & .14 & .41 & .51 & .33 & .43 & .55 & .26 & .16 & .36 & .45 & .39 \\
\hline .21 & .21 & .16 & .20 & .19 & .20 & .19 & .20 & .16 & .16 & .19 & .20 & .20 \\
\hline .20 & .10 & .10 & .41 & .07 & .01 & .16 & .04 & .10 & & .09 & .10 & $\cdots$ \\
\hline & & .03 & .03 & .05 & .03 & .03 & .04 & .04 & & .03 & .03 & \\
\hline 5 & $\overline{.14}$ & 99.97 & 99.96 & 00.08 & 99.99 & 99.98 & 99.96 & & & & & \\
\hline .02 & .02 & .01 & .02 & .02 & .01 & .01 & .02 & - & $\cdots$ & $\ldots$ & .. & . \\
\hline 99.9 & 100.38 & 99.96 & 99.94 & 100.06 & 99.98 & 99.97 & 99.94 & & .. & . & & ․ \\
\hline
\end{tabular}

the Starlight Formation and those in younger basalts can be seen. The greatest difference is in the barium content. Barium and strontium are consistently higher in the Starlight flows; also, cobalt, copper, and vanadium are all persistently very slightly lower in the Starlight basalts than in the younger basalts. .

Thus, two chemically distinctive types of basaltic rocks occur in this area-the Starlight, which is similar to the "Central" type of Nockolds (1954), and the younger basalts, which are generally similar to normal alkali basalt. Minor differences in trace elements also are apparent between the two groups.

The marked differences in the chemical composition of the two groups of basalts suggest different magmatic sources for the basalt of the Starlight Formation and for the younger basalts of the Massacre Volcanics, Big Hole Basalt, and Cedar Butte Basalt. The similarity of the group of basalts to each other suggests that they are comagmatic.

\section{COMPOSITION OF THE SILICIC ROCKS}

As shown by table 9, the silicic rocks of the Rockland-Arbon area and surrounding region are calc-alkali rhyolitic rocks that vary chemically only in detail. It is noteworthy that no dacites are 
TABLE 8.-Spectrographic analyses for trace elements, in parts per million, in basaltic rocks of the American Falls area, Idaho

[Zinc analyses by Claude Huffman and Henry $\mathrm{H}$. Lupp, determined by resin-carbonate-zincon method; all other analyses by Paul R. Barnett. All except those for Zn are quantitative spectrographic analyses, which have an overall accuracy of \pm 15 percent, except that they are less accurate near limits of detection where only one digit is reported. Looked for but not detected: Ag, As, Au, B, Bi, Cd, Ge, In, Pt, Sb, Ta, Th, Tl, U, W, and $\mathrm{Zn}$. < , less than; leaders (....) indicate not determined]

\begin{tabular}{|c|c|c|c|c|c|c|c|c|c|c|c|c|c|c|c|c|c|c|}
\hline \multirow{2}{*}{$\begin{array}{l}\text { Element } \\
\qquad \text { Sample No........... }\end{array}$} & \multicolumn{5}{|c|}{ Starlight Formation } & \multicolumn{8}{|c|}{ Massacre Volcanics } & \multicolumn{3}{|c|}{ Big Hole Basalt } & \multicolumn{2}{|c|}{ Butte Basalt } \\
\hline & 1 & 2 & 3 & 4 & 5 & 6 & 7 & 8 & 9 & 10 & 11 & 12 & 13 & 14 & 15 & 16 & 17 & 18 \\
\hline $\begin{array}{l}\mathrm{Ba} \ldots \ldots \ldots \ldots \\
\mathrm{Be} \ldots \ldots \ldots \ldots \ldots \\
\text { Co } \ldots \ldots \ldots \ldots \ldots \ldots \\
\text { Cr } \ldots \ldots \ldots \ldots \ldots \ldots \\
\text { Cu. } \ldots \ldots \ldots \ldots \ldots\end{array}$ & $\begin{array}{c}970 \\
4 \\
42 \\
10 \\
52\end{array}$ & $\begin{array}{r}650 \\
2 \\
46 \\
120 \\
48\end{array}$ & $\begin{array}{l}800 \\
\cdots \\
45 \\
73 \\
52\end{array}$ & $\begin{array}{r}970 \\
3 \\
38 \\
410 \\
38\end{array}$ & $\begin{array}{r}540 \\
\cdots \\
38 \\
330 \\
20\end{array}$ & $\begin{array}{r}280 \\
2 \\
51 \\
71 \\
64\end{array}$ & $\begin{array}{r}280 \\
2 \\
58 \\
82 \\
64\end{array}$ & $\begin{array}{r}280 \\
2 \\
52 \\
210 \\
70\end{array}$ & $\begin{array}{r}310 \\
\cdots \\
55 \\
400 \\
80\end{array}$ & $\begin{array}{r}330 \\
\cdots \\
50 \\
250 \\
66\end{array}$ & $\begin{array}{r}380 \\
\cdots \\
60 \\
300 \\
79\end{array}$ & $\begin{array}{r}320 \\
\ldots \\
52 \\
290 \\
90\end{array}$ & $\begin{array}{r}360 \\
73 \\
71 \\
68\end{array}$ & $\begin{array}{r}380 \\
\cdots \\
68 \\
480 \\
85\end{array}$ & $\begin{array}{r}450 \\
7 \\
51 \\
360 \\
77\end{array}$ & $\begin{array}{r}250 \\
\cdots \\
61 \\
440 \\
70\end{array}$ & $\begin{array}{r}320 \\
\cdots \\
51 \\
360 \\
80\end{array}$ & $\begin{array}{r}420 \\
\cdots \\
56 \\
380 \\
80\end{array}$ \\
\hline 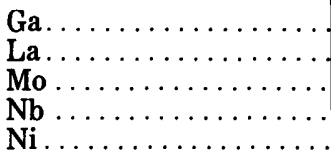 & $\begin{array}{l}14 \\
\cdots \\
\cdots \\
45\end{array}$ & $\begin{array}{r}12 \\
<80 \\
<4 \\
<20 \\
100\end{array}$ & $\begin{array}{l}14 \\
\cdots \\
\cdots \\
\ddot{74}\end{array}$ & $\begin{array}{l}14 \\
\cdots \\
\cdots \\
110\end{array}$ & $\begin{array}{r}20 \\
\cdots \\
30 \\
\mathbf{3 0 0}\end{array}$ & $\begin{array}{r}12 \\
<80 \\
<4 \\
<20 \\
100\end{array}$ & $\begin{array}{r}14 \\
<80 \\
<4 \\
<20 \\
120\end{array}$ & $\begin{array}{r}14 \\
<80 \\
<4 \\
<2 \\
120\end{array}$ & $\begin{array}{l}14 \\
\cdots \\
\cdots \\
110\end{array}$ & $\begin{array}{l}15 \\
\cdots \\
\cdots \\
100\end{array}$ & $\begin{array}{l}\mathbf{1 6} \\
\cdots \\
\cdots \\
\mathrm{i10}\end{array}$ & $\begin{array}{l}19 \\
\cdots \\
\cdots \\
76\end{array}$ & $\begin{array}{l}13 \\
\cdots \\
\cdots \\
77\end{array}$ & $\begin{array}{l}15 \\
\cdots \\
\cdots \\
150\end{array}$ & $\begin{array}{c}15 \\
\ldots \\
\ldots \\
\ddot{96}\end{array}$ & $\begin{array}{c}22 \\
\ldots \\
\ldots \\
\mathbf{3 0} \\
\mathbf{1 7 0}\end{array}$ & $\begin{array}{c}21 \\
\ldots \\
\ldots \\
40 \\
120\end{array}$ & $\begin{array}{r}24 \\
\ldots \\
\ldots \\
50 \\
110\end{array}$ \\
\hline $\begin{array}{l}\mathrm{Pb} \\
\mathrm{Sc} . \\
\mathrm{Sn} \\
\mathrm{Sr} . \\
\mathrm{V} .\end{array}$ & 28 & $\begin{array}{r}<10 \\
27 \\
<3 \\
400 \\
87\end{array}$ & $\begin{array}{l}30 \\
30 \\
350 \\
180\end{array}$ & $\begin{array}{r}30 \\
\mathbf{5} 50 \\
200\end{array}$ & $\begin{array}{r}40 \\
300 \\
200\end{array}$ & $\begin{array}{r}<10 \\
28 \\
<3 \\
300 \\
220\end{array}$ & $\begin{array}{r}<\mathbf{1 0} \\
\mathbf{3 3} \\
<\mathbf{3} \\
\mathbf{3 0 0} \\
\mathbf{3 0 0}\end{array}$ & $\begin{array}{r}<10 \\
\mathbf{3 4} \\
<\mathbf{3} \\
\mathbf{3 0 0} \\
\mathbf{3 0 0}\end{array}$ & $\begin{array}{r}42 \\
250 \\
290\end{array}$ & $\begin{array}{r}\ddot{37} \\
\dot{250} \\
\mathbf{2 9 0}\end{array}$ & $\begin{array}{r}4 \dot{42} \\
\ddot{2} \dot{50} \\
340\end{array}$ & $\begin{array}{l}\ddot{44} \\
30 \dot{300} \\
370\end{array}$ & $\begin{array}{l}\dot{31} \\
\ddot{200} \\
220\end{array}$ & $\begin{array}{r}39 \\
\ddot{250} \\
280\end{array}$ & $\begin{array}{l}34 \\
300 \\
240\end{array}$ & $\begin{array}{r}40 \\
100 \\
280\end{array}$ & $\begin{array}{r}40 \\
180 \\
290\end{array}$ & $\begin{array}{r}50 \\
230 \\
300\end{array}$ \\
\hline 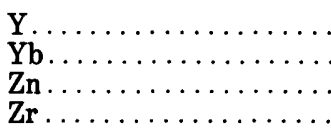 & $\begin{array}{r}30 \\
4 \\
140\end{array}$ & $\begin{array}{r}30 \\
4 \\
130 \\
90\end{array}$ & $\begin{array}{r}30 \\
4 \\
130\end{array}$ & $\begin{array}{r}40 \\
4 \\
200\end{array}$ & $\begin{array}{r}40 \\
3 \\
120\end{array}$ & $\begin{array}{r}30 \\
4 \\
110 \\
150\end{array}$ & $\begin{array}{r}40 \\
4 \\
110 \\
140\end{array}$ & $\begin{array}{r}40 \\
5 \\
100 \\
150\end{array}$ & $\begin{array}{r}30 \\
5 \\
110\end{array}$ & $\begin{array}{r}40 \\
5 \\
180\end{array}$ & $\begin{array}{r}50 \\
6 \\
200\end{array}$ & $\begin{array}{r}50 \\
5 \\
\ddot{2} \dot{5} 0\end{array}$ & $\begin{array}{r}30 \\
5 \\
160\end{array}$ & $\begin{array}{r}40 \\
5 \\
200\end{array}$ & $\begin{array}{r}40 \\
4 \\
26 \dot{0}\end{array}$ & $\begin{array}{r}40 \\
4 \\
160\end{array}$ & $\begin{array}{r}40 \\
4 \\
180\end{array}$ & $\begin{array}{r}60 \\
5\end{array}$ \\
\hline
\end{tabular}


present. In general, the silicic rocks appear to be slightly lower in alumina and higher in potassia than comparable rocks from other volcanic areas of western Utah and Nevada. Fluorine and titania also are relatively high in some samples. The high $\mathrm{K}_{2} \mathrm{O}$ content fits well with the generally high values of the eastern Great Basin. The average $\mathrm{K}_{2} \mathrm{O}$ of the analyses (excluding sample 10) in table 9, plus 17 partial analyses of samples for the same rock units, gives an average of 5.53 weight-percent $\mathrm{K}_{2} \mathrm{O}$.

Included in table 9 are a tuff from the Black Pine Range (Sample No. 14), tuffs from east of Idaho Falls (samples 13, 18), and a Pleistocene tuff from near Pocatello (sample 19). Chemically, these rocks are indistinguishable from the tuffs of the Starlight and Walcott Formations of the Rockland-Arbon area. Sample 10 is from a rhyolitic dike that is contaminated with basaltic material. This rock has been described in the preceding section, and the analysis is included here to show the variation in composition produced by the addition of a small amount of basalt magma. In addition to shifts in silica and alkali contents, the $\mathrm{P}_{2} \mathrm{O}_{5}$ and $\mathrm{MnO}$ content of this rock is distinctly higher than in uncontaminated rhyolites. Certain minor elements also reflect the addition of basic magma, notably $\mathrm{Cr}, \mathrm{Co}$, $\mathrm{Cu}, \mathrm{Ni}, \mathrm{Sr}$, and $\mathrm{V}$, all of which are higher in the contaminated rock.

The chemical data presently available for this region indicate that the silicic volcanic rocks probably are from the same magma, and that, in general, mixing of basic and silicic magma probably did not occur, nor was there significant differentiation in the silicic magma chamber.

\section{STRUCTURE}

The structural boundary between the Basin and Range physiographic province and the Snake River Plain section of the Columbia Plateaus physiographic province passes through the northwestern part of the Rockland quadrangle. The Deep Creek Mountains and the Sublett and Bannock Ranges are internally broken structural blocks bounded by basin-and-range faults on the west and the east, and by the Snake River Plain on the north. The intermontane valleys are structural valleys partly filled with Tertiary volcanic rocks. A major thrust fault passes through this area and is truncated by the margin of the Snake River Plain. The Snake River Plain is a structural depression, probably fault bounded, that is filled with Tertiary and Quaternary volcanic and sedimentary rocks.

The Paleozoic rocks that compose the mountain blocks have been warped into broad open folds and have been broken by an episode of major thrust faulting, with associated folding and normal faulting, 
TABLE 9.-Composition of the silicic rocks of the Rockland-

\begin{tabular}{|c|c|c|c|c|c|c|c|}
\hline \multirow[b]{2}{*}{ Constituent } & \multicolumn{7}{|c|}{ Starlight Formation } \\
\hline & \multicolumn{3}{|c|}{ Lower member } & $\begin{array}{c}\text { Tuff of } \\
\text { Arbon Valley }\end{array}$ & \multicolumn{3}{|c|}{ Upper member } \\
\hline $\begin{array}{l}\text { Sample No. } \\
\text { Lab. No.... }\end{array}$ & $\begin{array}{l}1 \\
\text { E190 }\end{array}$ & $\begin{array}{r}\mathbf{2} \\
\mathrm{H} 3266\end{array}$ & $\begin{array}{c}3 \\
\text { H3267 }\end{array}$ & $\begin{array}{cc}4 & 5 \\
\text { D1759 } & \mathbf{5} 3189\end{array}$ & $\begin{array}{cc}6 & 7 \\
\text { H3268 H3270 }\end{array}$ & $\begin{array}{c}8 \\
\text { H3273 }\end{array}$ & $\begin{array}{c}9 \\
\text { E1895 }\end{array}$ \\
\hline
\end{tabular}

Standard rock analyses

[Analyzed by D. F. Powers by standard methods; analyses

\begin{tabular}{|c|c|c|c|c|c|c|c|c|c|}
\hline $\begin{array}{l}\mathrm{SiO}_{2} \ldots \ldots \ldots \ldots \\
\mathrm{Al}_{20} \mathrm{O}_{3} \ldots \ldots \ldots \ldots \\
\mathrm{Fe}_{203} \ldots \ldots \ldots \ldots \\
\mathrm{FeO} \ldots \ldots \ldots \ldots\end{array}$ & $\begin{array}{r}2.23 \\
1.52 \\
.70 \\
.90\end{array}$ & $\begin{array}{r}72.65 \\
11.55 \\
.75 \\
.63\end{array}$ & $\begin{array}{r}70.27 \\
11.80 \\
.75 \\
1.71\end{array}$ & $\begin{array}{r}74.60 \\
13.42 \\
.50 \\
.41\end{array}$ & $\begin{array}{r}71.59 \\
13.00 \\
1.06 \\
.25\end{array}$ & $\begin{array}{r}74.18 \\
11.59 \\
.81 \\
.70\end{array}$ & $\begin{array}{r}71.77 \\
11.91 \\
1.17 \\
1.44\end{array}$ & $\begin{array}{r}71.77 \\
11.51 \\
.82 \\
.94\end{array}$ & $\begin{array}{r}72.25 \\
11.74 \\
.65 \\
.59\end{array}$ \\
\hline $\begin{array}{l}\mathrm{CaO} \\
\mathrm{Na}_{2} \mathrm{O} \\
\mathrm{K}_{2} \mathrm{O}\end{array}$ & $\begin{array}{r}.11 \\
.56 \\
1.55 \\
6.72\end{array}$ & $\begin{array}{r}.11 \\
.54 \\
1.63 \\
6.53\end{array}$ & $\begin{array}{l}.21 \\
1.03 \\
2.48 \\
5.17\end{array}$ & $\begin{array}{l}.17 \\
1.14 \\
3.29 \\
\mathbf{5 . 3 5}\end{array}$ & $\begin{array}{r}.57 \\
.98 \\
3.24 \\
4.43\end{array}$ & $\begin{array}{r}.07 \\
.55 \\
2.44 \\
6.13\end{array}$ & $\begin{array}{r}.19 \\
1.15 \\
2.15 \\
6.02\end{array}$ & $\begin{array}{r}.33 \\
.71 \\
1.99 \\
5.35\end{array}$ & $\begin{array}{r}.23 \\
.55 \\
2.44 \\
5.61\end{array}$ \\
\hline $\begin{array}{l}\mathrm{H}_{2} \mathrm{O}+ \\
\mathrm{H}_{2} \mathrm{O}- \\
\mathrm{TiO}_{2} \text {. } \\
\mathrm{P}_{2} \mathrm{O}_{5}\end{array}$ & $\begin{array}{r}4.67 \\
.20 \\
.19 \\
.01\end{array}$ & $\begin{array}{r}4.62 \\
.10 \\
.16 \\
.01\end{array}$ & $\begin{array}{r}4.93 \\
.09 \\
.38 \\
.04\end{array}$ & $\begin{array}{l}.15 \\
.22 \\
.21 \\
.05\end{array}$ & $\begin{array}{r}2.45 \\
1.50 \\
.10 \\
.01\end{array}$ & $\begin{array}{r}2.57 \\
.04 \\
.16 \\
.01\end{array}$ & $\begin{array}{r}2.89 \\
.19 \\
.36 \\
.04\end{array}$ & $\begin{array}{r}4.76 \\
.91 \\
.24 \\
.01\end{array}$ & $\begin{array}{r}.46 \\
4.75 \\
.21 \\
.02\end{array}$ \\
\hline $\begin{array}{l}\mathrm{MnO} \\
\mathrm{CO} 2 \\
\mathrm{Cl} . .\end{array}$ & $\begin{array}{l}.08 \\
.01\end{array}$ & $\begin{array}{l}.03 \\
\ldots\end{array}$ & $\begin{array}{l}.05 \\
\ldots\end{array}$ & $\begin{array}{l}.02 \\
\ldots \\
\ldots\end{array}$ & $\begin{array}{l}.04 \\
.08 \\
.07 \\
.19\end{array}$ & $\begin{array}{l}.03 \\
.01\end{array}$ & $\begin{array}{l}.05 \\
\ldots \\
\ldots\end{array}$ & $\begin{array}{l}.03 \\
.01\end{array}$ & $\begin{array}{l}.03 \\
.00\end{array}$ \\
\hline $\begin{array}{l}\text { Subt } \\
\text { Less }\end{array}$ & $\begin{array}{r}99.52 \\
.05\end{array}$ & $\begin{array}{r}99.44 \\
.07\end{array}$ & $\begin{array}{r}99.10 \\
.03\end{array}$ & $\begin{array}{r}99.57 \\
.02\end{array}$ & $\begin{array}{r}99.56 \\
.10\end{array}$ & $\begin{array}{r}99.37 \\
.05\end{array}$ & $\begin{array}{c}99.38 \\
\ldots\end{array}$ & $\begin{array}{r}99.46 \\
.04\end{array}$ & $\begin{array}{r}99.66 \\
.05\end{array}$ \\
\hline $\begin{array}{l}\text { Total } \ldots \ldots \\
\mathrm{Na} 2 \mathrm{O}+\mathrm{K} 2 \mathrm{O}\end{array}$ & $\begin{array}{r}99.47 \\
8.27\end{array}$ & $\begin{array}{r}99.37 \\
8.16\end{array}$ & $\begin{array}{r}99.07 \\
7.65\end{array}$ & $\begin{array}{r}99.55 \\
8.64\end{array}$ & $\begin{array}{r}99.46 \\
7.67\end{array}$ & $\begin{array}{r}99.32 \\
8.57\end{array}$ & $\begin{array}{r}99.38 \\
8.17\end{array}$ & $\begin{array}{r}99.42 \\
7.34\end{array}$ & $\begin{array}{r}99.61 \\
8.05\end{array}$ \\
\hline
\end{tabular}

[Analyzed by P. R. Barnett by quantitative spectrographic methods, which have an overall accuracy of \pm 15 (...) indicate not determined; <, less than. Looked for but not

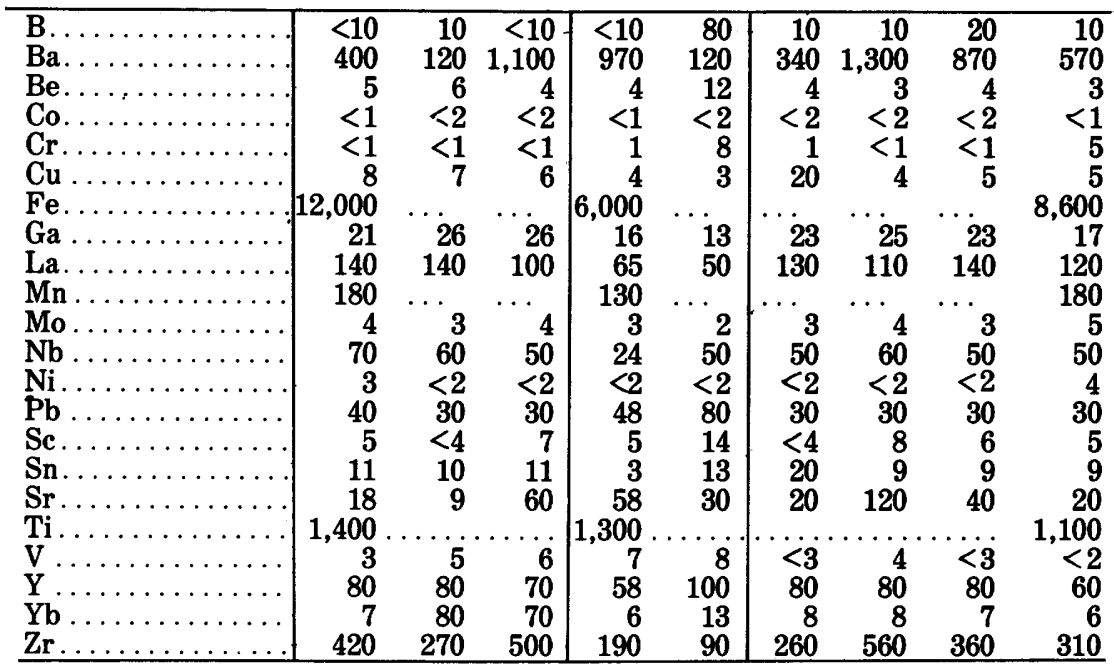

${ }^{1}$ Includes $0.11 \mathrm{BaO} . \quad{ }^{2}$ Rock contains a small amount of calcite. 
Arbon area and other localities in southeastern Idaho

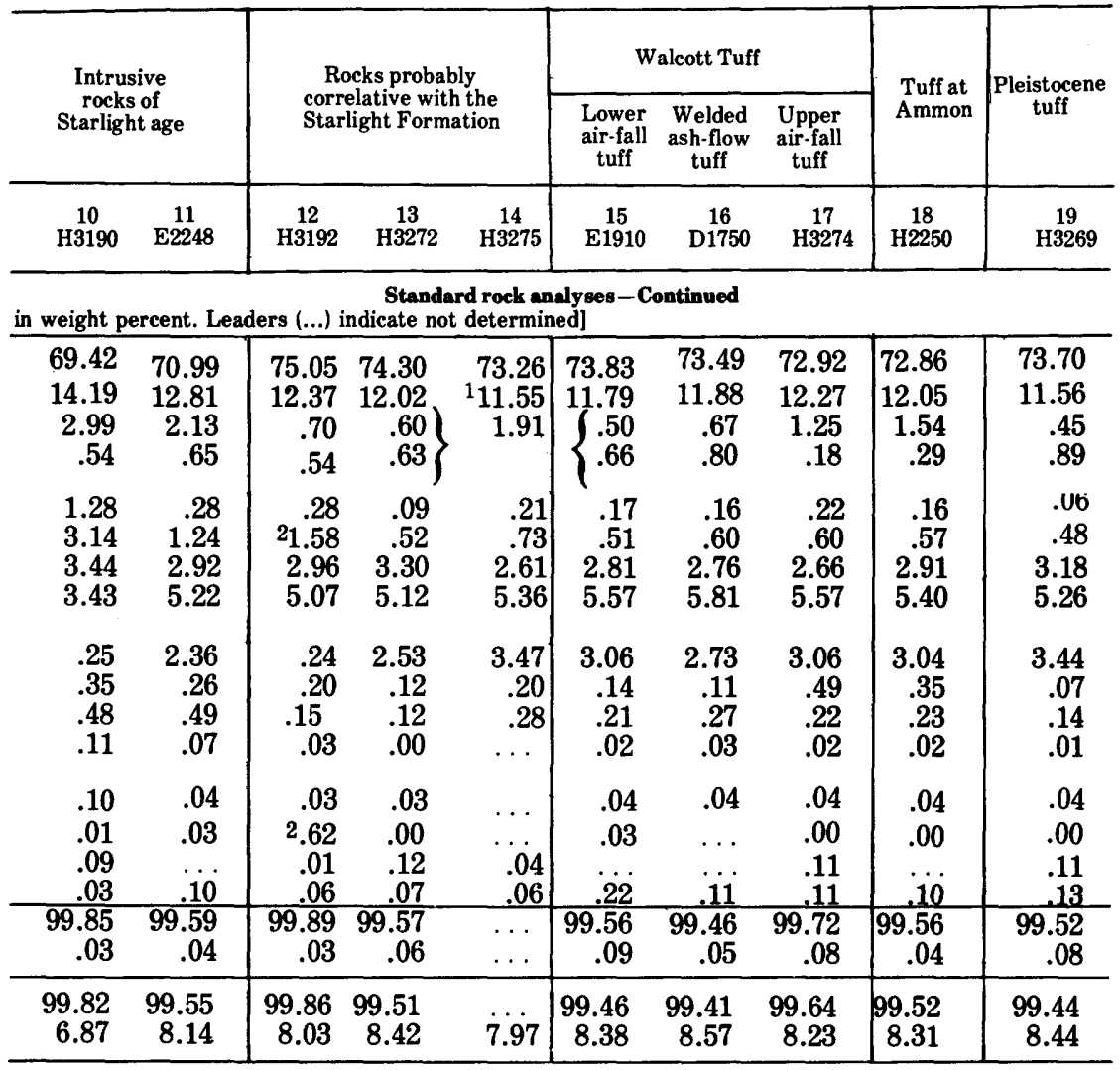

Trace element analyses - Continued

percent, except that they are less accurate near limits of detection; analyses in parts per million. Leaders found: Ag, As, Au, Bi, Cd, Ge, In, Pt, Sb, Ta, Th, Tl, U, W, Zn]

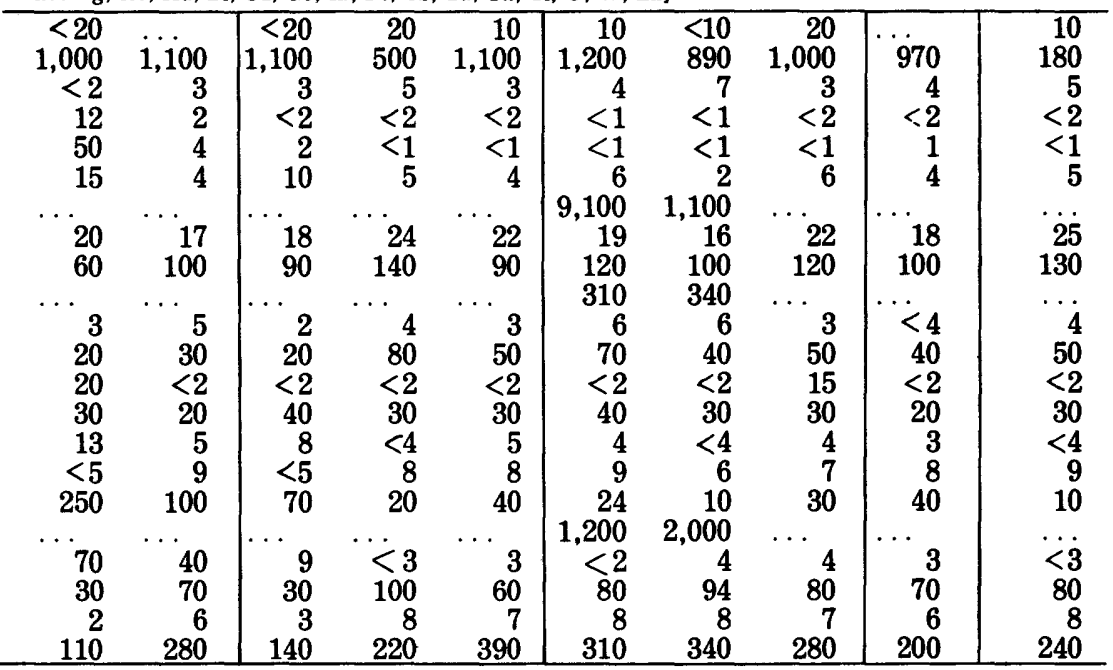

See sample descriptions and localities on page 88 . 
T ABLE 9.-Composition of the silicic rocks of the Rockland-Arbon area and other localities in southeastern Idaho-Continued

\section{SAMPLE DESCRIPTIONS AND LOCALITIES}

No.

1. Cleaned volcanic ash (essentially vitric shards, cleaned with bromoform and ultrasonic treatment) Mollys Nipple, SW1/4 sec. 29 , T. 10 S., R. 31 E., Rockland quadrangle. Collected by H. A. Powers.

2. Cleaned volcanic ash, $\mathrm{NW}^{1 / 4} \mathrm{NW}^{1 / 4}$ sec. 31, T. $6 \mathrm{~S}$., R. $34 \mathrm{E}$., Michaud quadrangle.

3. Cleaned volcanic ash, immediately below base of tuff of Arbon Valley, SW $1 / 4$ sec. 29, T. 7 S., R. 33 E., Michaud quadrangle.

4. Ash-flow tuff, nonwelded lower part, same locality as sample 1 .

5. Ash-flow tuff, partially welded upper part, NE $1 / 4 W^{1 / 4}$ sec. 32, T. 7 S., R. 32 E., Michaud quadrangle.

6. Ash-flow tuff, nonwelded top of a welded obsidian tuff that overlies the tuff of Arbon Valley, $\mathrm{SW}^{1 / 4} \mathrm{SE}^{1 / 4}$ sec. 21, T. 7 S., R. 32 E., Michaud quadrangle.

7. Cleaned volcanic ash. NW1/4 SW1/4 sec. 22 , T. 10 S., R. 30 E., Rockland quadrangle.

8. Cleaned volcanic ash, NE $1 / 4$ NW $1 / 4$ sec. 33, T. 8 S., R. 31 E., Rockland quadrangle.

9. Cleaned volcanic ash, about 50 feet stratigraphically below base of Neeley Formation, upper Ferry Hollow, SW $1 / 4$ NE $1 / 4$ sec. 6, T. 8 S., R. 31 E., American Falls quadrangle.

10. Porphyry dike contaminated with inclusions of basaltic material; intrudes lower member of Starlight Formation, SW $1 / 4 \mathrm{NW}^{1 / 4}$ sec. 24 , T. 7 S., R. $32 \mathrm{E}$. Michaud guadrangle.

11. Vitrophyre, intrudes upper part of upper member of Starlight Formation, NW1/4 sec. 27, T. 7 S., R. 31 E., American Falls quadrangle.

12. Lava flow, 9 miles northeast of Pocatello, SE $1 / 4 \mathrm{SE}^{1 / 4}$ sec. 8, T. 5 S., R. 35 E., Pocatello quadrangle.

13. Cleaned volcanic ash, about 17 miles east of Idaho Falls, roadcut in NE $1 / 4 \mathrm{SW} i / 4$ sec. 1, T. 2 N., R. 40 E., Poplar quadrangle.

14. Cleaned volcanic ash below welded obsidian tuff, north end of Black Pine Range, SW $1 / 4$ sec. 33, T. $13 \mathrm{~S}$., R. $28 \mathrm{E}$., Strevell quadrangle.

15. Cleaned volcanic ash, lower bedded part of Walcott Tuff, Ferry Hollow, NW1/4 sec. 6, T. 8 S., R. 31 E., American Falls quadrangle.

16. Ash-flow tuff, densely welded, viewpoint on Snake River, SW $1 / 4$ sec. 28, T. 8 S., R. 30 E., Rockland quadrangle.

17. Cleaned volcanic ash, probable air fall, 1 foot above top of ash-flow tuff, NW $1 / 4$ sec. 13, T. $9 \mathrm{~S} .$, R. 30 E., Rockland quadrangle.

18. Ash-flow tuff densely welded 3.3 miles northeast of Ammon, Idaho, NE1/4 SE $1 / 4$ sec. 19, T. 2 N., R. 39 E.

19. Cleaned volcanic ash bed in loess on Trail Creek road, 2 miles west of Pocatello, NE $1 / 4$ sec. 32 . T. 6 S., R. $34 \mathrm{E}$.

and by post-thrust basin-and-range faulting. Post-basin-and-range faulting that affected the Pliocene volcanic rocks was minor, and offsets commonly are less than 100 feet.

The autochthonous rocks of the Deep Creek Mountains are all part of a much-faulted synclinorium, except in the northwestern part of the range west of Bowen Canyon, where they form a distorted north-plunging anticline. These folds are broken by north-trending faults of relatively small displacement, some of which pass into minor flexures.

The rocks of the White Quartz Mountain-Bannock Peak area and those east of Squaw Creek in the Deep Creek Mountains and the Paleozoic rocks east of Bannock Creek in the Arbon quadrangle are all part of a large thrust plate, bounded on the west by a major east-dipping thrust fault and fragmented by tear faults and normal faults. The rocks of the upper plate both east and west of Bannock Creek locally are complexly broken by normal faults, as well as by several subsidiary thrust slivers. The trace of the thrust plane west of White Quartz Mountain, here called the Deep Creek Mountains thrust fault, is marked by the contact between the allochthonous Ordovician rocks on the east and the Pennsylvanian and Permian autochthonous rocks of the Oquirrh Formation on the west. In this vicinity the thrust plane dips generally northeastward. The trace of 
the thrust plane has been offset eastward both north and south of the White Quartz Mountain-Bannock Peak area by east-trending tear faults, which indicate the direction of stress. South of the boundary of the Fort Hall Indian Reservation, the thrust trace presumably turns southward and is concealed beneath the younger rocks that partly fill Arbon Valley. To the north, long segments of the thrust trace also are concealed by Tertiary and Quaternary rocks. Isolated exposures of Ordovician and Silurian rocks near the Garden Ranch at the north boundary of the Rockland quadrangle are part of the thrust plate; the concealed fault trace lies west of these exposures. All the Paleozoic rocks east of Bannock Creek and those in the north-central part of the Arbon quadrangle, west of Bannock Creek, are also interpreted as being partof the thrust plate.

The Deep Creek Mountains thrust is thought by us to be part of the west boundary of a large klippe (fig. 15) that is bounded on the east by the Paris and Woodruff Creek thrust faults, on the south by the Willard thrust near Ogden, Utah, and on the north by the Putnam thrust of Mansfield (1920, pl. 3). The area bounded by these faults and their presumed continuations forms a block, 120 miles long and as much as 50-60 miles wide, in which the exposed pre-Tertiary rocks are mostly Mississippian and older. Autochthonous preTertiary rocks at nearly all places adjacent to the thrust boundary are Mississippian or younger, mostly younger.

The connection of the Willard thrust with the Woodruff Creek thrust fault to form the southern boundary of this structural feature has been described (Roberts and others, 1965, fig. 17, p. 1947; R. L. Armstrong, 1968, p. 440). Roberts and his colleagues also suggested a possible connection between the Willard thrust and the Charleston thrust, farther south of the Wasatch Range, Utah, but did not suggest the connection of the Willard thrust with the fault that is probably a thrust fault in the West Hills, Utah, at the Idaho boundary. The stratigraphic relations at the fault trace in the West Hills are essentially the same as those in the Deep Creek Mountains, and the fault in the West Hills is here considered to be part of the thrust boundary and to connect with the Willard thrust on the south and with the Deep Creek Mountains thrust on the north.

The age of this thrust faulting can not be determined from this area, nor can the direction of movement, except that it was east or west. Others (Crittenden, 1961) have concluded that the direction of movement on possible connecting faults, such as the Willard, was to the east and the displacement was on the order of 40 miles. Armstrong and Cressman (1963, p. J14) concluded that movement on the Paris fault was initiated in Late Jurassic or Early Cretaceous time. By inference it may be concluded that movement on the other 

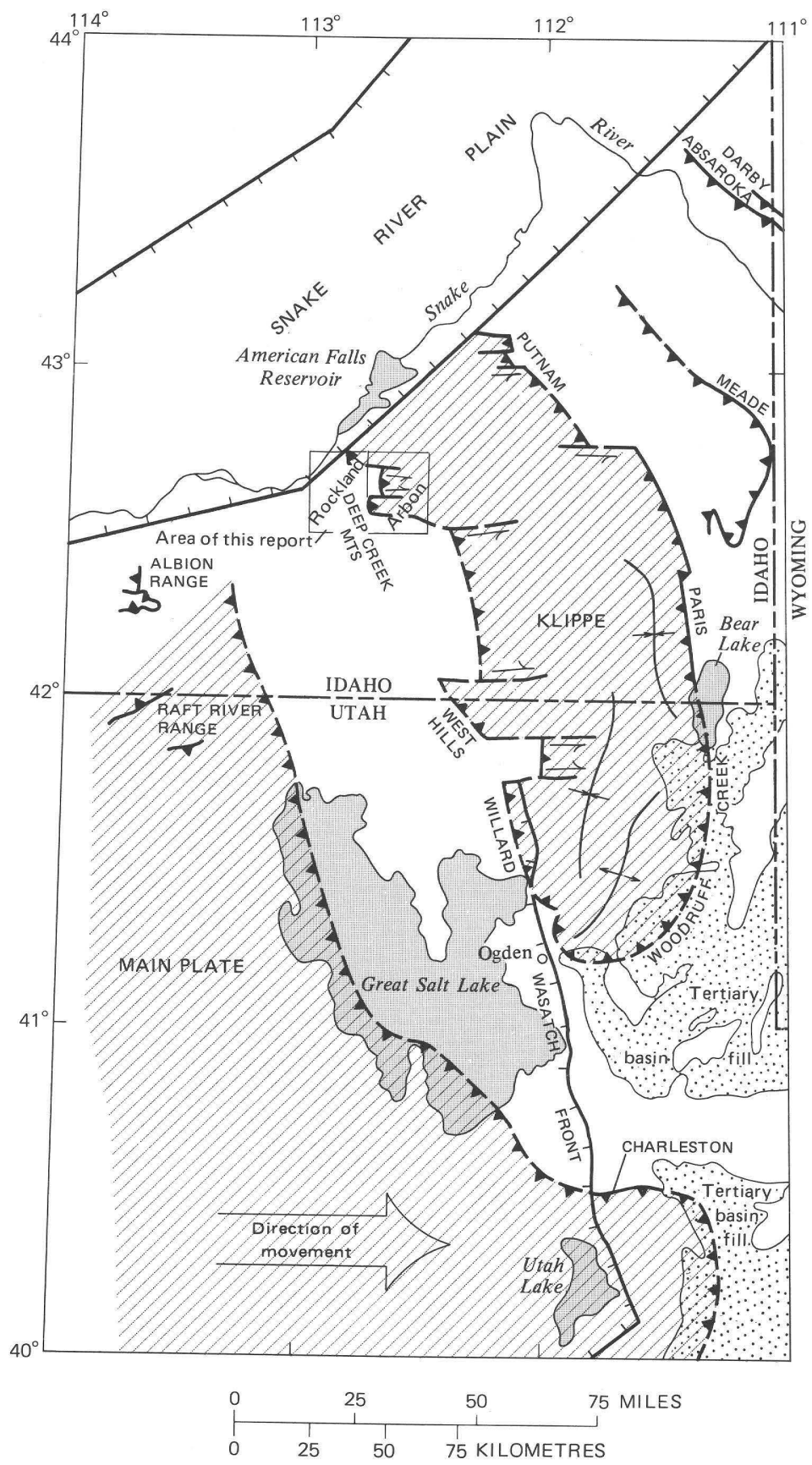

FIGURE 15.-Interpreted relationships of thrust faults in southeastern Idaho and northern Utah. Thrust faults are shown by sawteeth, which are in upper plate. Normal faults are shown by hachures, which are on downdropped side. Arrows show direction of movement along tear faults. 
faults began at the same time, inasmuch as they are interpreted to be traces of the same fault plane or sole.

The basin-and-range episode of faulting outlined the mountain blocks and intermontane valleys. The displacement on the main frontal faults of the mountain ranges is not known but is several thousand feet. South of Buck Canyon, the Rockland Valley fault along the west base of the Deep Creek Mountains is marked by a conspicuous, almost continuous breccia. The springs that are the source for East Fork Rock Creek issue from this fault zone.

In the Deep Creek Mountains two northeast-trending faults-one in the area of Hunter Canyon and the other mostly south of East Fork Rock Creek-have displacements of several thousand feet. Another normal fault of large displacement, with the upthrown side to the east, follows Bowen Canyon and probably also has a displacement of several thousand feet. The Warner Flat fault, east of Howard Flat and Warner Flat, in the Arbon quadrangle, is another normal fault, upthrown on the east with several thousand feet of displacement, that repeats the stratigraphic sequence. These faults probably were formed during the episode of Basin and Range faulting, as no prethrust episode of large displacement normal faulting is known elsewhere in the region, and no evidence is present here to indicate a prethrust age for these faults.

Rockland and Arbon Valleys are grabens of the basin-and-range type. The Paleozoic rocks exposed on Cedar Ridge, well out in Rockland Valley, and on the outlier of the Bannock Range that forms the broad ridge north of Pauline may be horsts bounded by concealed faults having the same general trend as those that border the valleys. Movement on basin-and-range faults was largely completed before the outpouring of the middle Pliocene volcanic rocks that partly fill the structural valleys.

The origin of the Snake River Plain has been discussed by geologists, with little agreement, since Kirkham (1931) suggested that it is a downwarp. We believe that the Snake River Plain is a graben principally because of the abrupt termination of the mountain ranges, both north and south of the plain. A fault zone at the south margin of the plain is further suggested by a coincidence of several geologic features along the line of truncation of the Paleozoic rocks of the mountain ranges. These features include a northeast-trending set of faults of small displacement in Tertiary rocks, outcrops of vitrophyre and brecciated rocks at intervals along this line for about 35 miles, between the north end of the Sublett Range and the north end of the Bannock Range, and the large springs that are the main source of Fall Creek, at the north end of the Sublett Range about 4 miles west of the Rockland quadrangle. A strong positive gravity 
gradient toward the Snake River has been given as additional evidence of such a fault zone (Carr and Trimble, 1963, p. G37).

The Snake River Plain graben truncates the basin-and-range faults that outline the mountain and valley blocks, but the graben also predates the middle Pliocene volcanic rocks that partly fill it. According to Malde (1959), the period of major subsidence of the western Snake River Plain probably was in early or middle Pliocene time. R. R. Coats (in U.S. Geological Survey, 1964, p. A109), however, has suggested that the Snake River Plain may have been outlined by faulting as early as Miocene. Although it postdates the main episodes of basin-and-range faulting, we consider the Snake River Plain graben to be a basin-and-range feature that has resulted from continued application of the same tensional stresses that produced the mountain and valley blocks.

Minor reactivation of movement on the basin-and-range faults is represented by the many faults of small displacement that break the Tertiary and Quaternary (?) rocks. The Ferry Hollow graben (Carr and Trimble, 1963) is a conspicuous feature in the northern part of the Rockland quadrangle. Its bounding faults, with displacements of only about 100 feet, probably resulted from recurrent movement along the major fault system at the west margin of the Deep Creek Mountains. Several other minor faults have been noted that offset upper Tertiary and Quaternary(?) rocks. Rocks of the Starlight Formation have been offset by faulting at Mollys Nipple in Rockland Valley and both east and west of Bannock Creek in the northern part of the Arbon quadrangle. Upper Tertiary rocks and rocks of the Little Creek Formation and Massacre Volcanics are cut by many small faults exposed along the Snake River, in tributary valleys and ravines, and in the hilly area in the northeastern part of the Rockland quadrangle. Basalt flows of the Massacre Volcanics are broken by faults of small displacement on the east side of Table Mountain. These lesser faults are divisible into two sets, the more prominent of which trends N. $10^{\circ}-20^{\circ} \mathrm{W}$. parallel to the basin-and-range faults, and the less prominent of which trends northeast, parallel to the margin of the Snake River Plain. All these faults dip steeply, and most have displacements of less than 50 feet.

Near the Snake River Plain the Tertiary rocks dip gently toward the plain, except for the Starlight Formation, which has been greatly warped (fig. 16). Beds of the Starlight, as shown by structure contours on the tuff of Arbon Valley, have a structural relief of nearly 2,000 feet. The present land surface conforms in a general way to the structure of the underlying Starlight. The topographically high area at the north end of the Deep Creek Mountains is a structural high, and Bannock Creek closely follows 

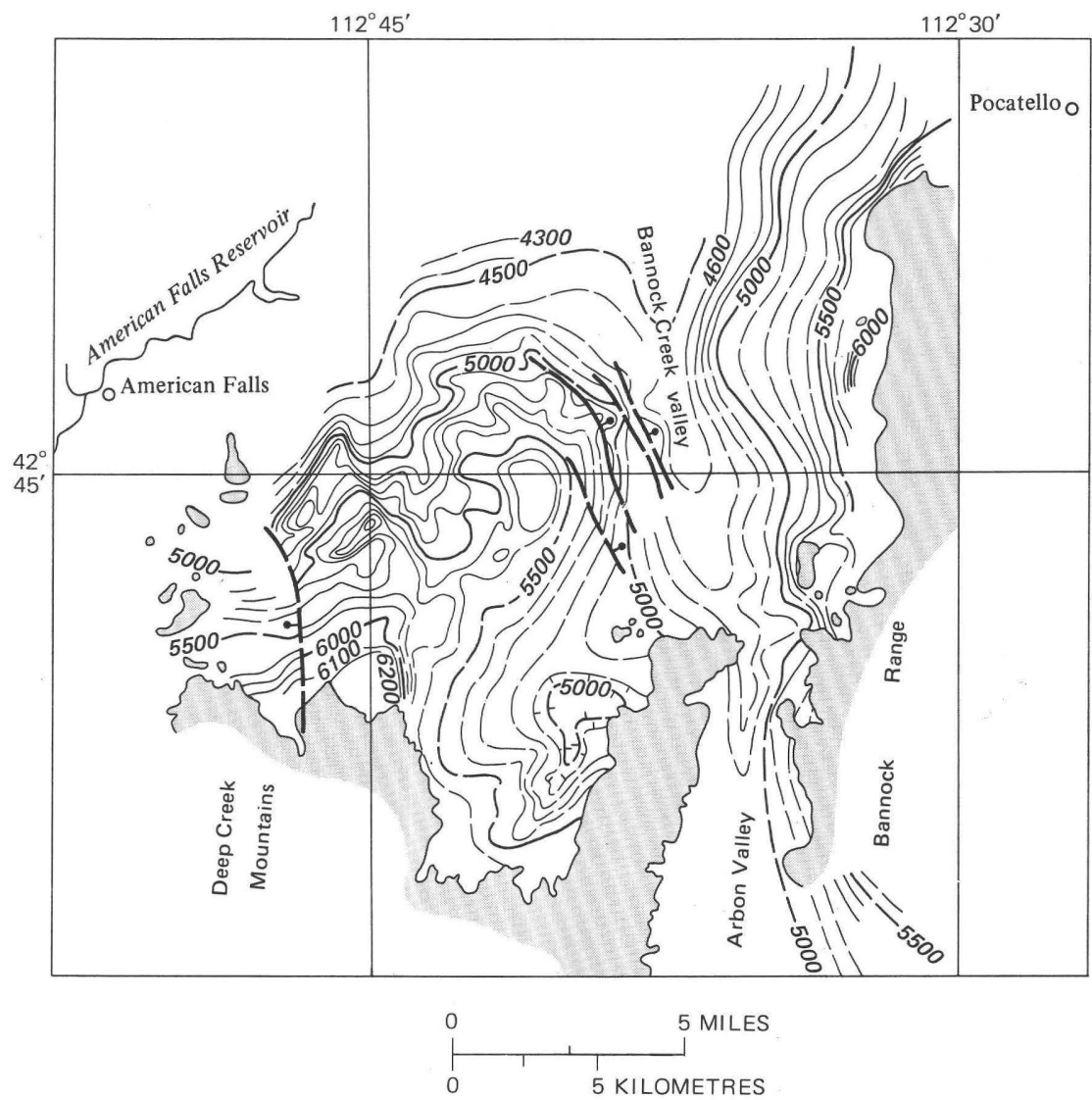

F IGURE 16.- Structure contours on the tuff of Arbon Valley, part of the middle member of the Starlight Formation. Patterned areas are pre-Tertiary rocks. Normal faults shown by heavy lines; bar and ball on downthrown side. Contour interval 100 feet; contour dashed where approximately located.

the axis of a synclinal valley. Dips in the Starlight may be partly initial dips but likely are the result mostly of tectonic warping. The downwarping may be largely the result of renewed subsidence of the graben valleys and of the Snake River Plain, owing to the removal of magma at depth by volcanic eruptions.

The Massacre Volcanics, of late Pliocene or early Pleistocene age, is the youngest formation known definitely to be faulted. A questionable fault in the Raft Formation was seen at only one locality. The American Falls Lake Beds are not disturbed.

\section{GEOLOGIC HISTORY}

Sedimentation, volcanism, and glaciation occurred in this region before Cambrian time, but their record is in rocks exposed northeast 
of the Rockland-Arbon area, not here. The earliest record here is of the nearshore deposition of marine sands (Camelback Mountain Quartzite) in a sinking miogeosyncline during Early Cambrian time. Deposition of marine sediments continued nearly uninterruptedly, mostly in shallow water, in this structural depression throughout the Paleozoic and into the Mesozoic Era. None of the Mesozoic record is present in the mapped area, either, but Triassic rocks are present to the southwest in the Sublett Range (Youngquist and Haegele, 1955); also, Triassic and Jurassic marine beds about 25 miles northeast of Pocatello (Mansfield, 1920) indicate continuation of deposition in the miogeosyncline throughout most of the Mesozoic.

Large-displacement gravity sliding within the miogeosyncline produced overthrust relations within the region, as well as folding and faulting of upper plate rocks and some folding in the lower plate rocks, probably in late Mesozoic.

In early to middle Tertiary, probably after an erosional period produced near planation, basin-and-range faulting created a system of generally north-trending mountains and valleys that was then truncated by the subsidence of the eastern Snake River Plain.

Volcanism, which probably was related to the subsidence of the Snake River Plain, characterized the middle and late Tertiary. The eruptive rocks were dominantly rhyolitic, although some centers erupted basaltic pyroclastic material, followed by basalt flows. The great volume of volcanic debris locally dammed stream valleys, and ponds and lakes were formed in which some of the rhyolitic ash was deposited. At least a few of the eruptions were very hot ash flows that covered hundreds of square miles.

Intermittent tectonic activity, perhaps related to the volcanic activity, caused recurrent movement along old fault lines, and the newly formed tuff deposits and basalt flows were broken repeatedly by small faults.

During the Pleistocene, successive eruptions produced a locally thick pile of basalt flows that nearly covered the Snake River Plain. These basaltic eruptions probably were intermittent and came from many vents, inasmuch as shield volcanoes dot the basaltic plain. The intermittent eruptive activity undoubtedly repeatedly blocked and diverted streams or dammed them to form lakes.

The pre-Bull Lake ancestral Snake River probably flowed near the north edge of the Snake River Plain. Tributary streams, such as the Raft River, Rock Creek, and Bannock Creek, flowed northward and were graded to the Snake. A local rise in base level, probably resulting from volcanism, caused aggradation by the tributary streams, and the fine-grained sediments of the Raft Formation were deposited in middle or late Pleistocene time. After the Raft 
Formation was deposited, a shallow ancestral Snake River valley was cut at the south edge of the plain, probably because of displacement of the river by eruptions of Big Hole Basalt. This valley, cut mainly in the Raft Formation, was probably about 2 miles wide in the vicinity of American Falls. Local base level was about 4,320 feet above sea level, and the gradient was very low. A thin but persistent alluvial gravel was deposited on the floor of this valley, probably in early Bull Lake or pre-Bull Lake (Illinoian) time.

Later eruption at Cedar Butte (Janies Nipple) and from other vents north of the Snake River built up a low cone and filled the Snake River valley with basaltic lava for a distance of at least 8 miles. These flows abutted against the Big Hole Basalt on the north and extended upriver to a point within about 2 miles of the north edge of the Rockland quadrangle. The upper surface of the lavas sloped gently upstream. The altitude of this surface between the vent area and Massacre Rocks was a little over 4,450 feet, and at the upstream edge altitude of the surface was probably about 4,370 feet. The Cedar Butte Basalt dammed the river, and water was impounded to a maximum level of about 4,450 feet above sea level. This level probably was determined by the altitude of the surface of the basalt at its northern and southern margins, the places where the water spilled westward. The altitude of these two points of spillover was evidently about the same.

The American Falls Lake Beds were deposited in the lake thus formed more than 42,000 years ago. The beds accumulated to a thickness of about 80 feet. About 30,000 years ago this lake was inundated by floodwaters of catastrophic proportions that originated in a spillover of pluvial Lake Bonneville. The detailed history of this flood has been described elsewhere (Trimble and Carr, 1961; Carr and Trimble, 1963; and Trimble, 1976). The present channel of the Snake River was cut by water of this flood, and terrace deposits and boulder bars are late stage products of the flood. The Snake River has cut downward more than 100 feet to its present level since the end of the Lake Bonneville overflow.

\section{ECONOMIC RESOURCES}

Sand and gravel and crushed rock are the only Earth materials presently considered to be of potential economic importance in this area, although uses may eventually be found for silicic pumice and tuff. There has been some prospecting in the area for barite, mercury, lead, and silver, but, except for a small amount of barite at one locality, the area appears to contain no metalliferous deposits. Phosphatic rock found during this study appears to be too thin to be of economic value.

Ground water is utilized for farming and domestic purposes. 


\section{GROUND WATER}

Ground water is one of the more important economic resources of this semiarid region, but the ground-water characteristics of the rocks of this area are poorly known. The importance of the basalt of the Snake River Plain as an aquifer has been pointed out by Stearns, Crandall, and Steward (1938, p. 58) and more recently by Crosthwaite (1957, p. 120). Most other Tertiary rocks in this area are likely to yield only small to moderate amounts of potable water (Crosthwaite, 1957, p. 118-119).

Fractured Paleozoic rocks, especially the carbonate rocks may have high ground-water yields. Large springs that are the source of East Fork Rock Creek issue from a thick fault breccia along the front of the Deep Creek Mountains. Most of the other springs east of Rock Creek and south of Rocky Hollow appear to issue from along the contact between the Tertiary tuff of the Starlight Formation and the overlying pediment gravel near the margin of the mappable gravel. This suggests that the underflow from the infiltration area along the mountain front moves through the gravel along the surface of the underlying tuff, and that relatively shallow wells, 100 feet deep or less, could obtain potable water from this horizon within 2 or 3 miles of the mountain front. The temperature of spring water in this area is generally between $47^{\circ}$ and $57^{\circ} \mathrm{F}$, except for the hot springs at Indian Springs and Warm Springs, which have water temperature of $90^{\circ}$ and $96^{\circ} \mathrm{F}$, respectively. These hot springs could have their source in a fault zone, which might account for their high temperature. In the mountains, small springs from perched water tables are fairly common in shaly rocks, particularly in the Manning Canyon Shale.

\section{SAND AND GRA VEL}

Sand and gravel has been obtained from several now abandoned pits in the older alluvium along the south side of the Snake River northwest of Neeley, and from two pits in the older alluvium in a channel east of Neeley, between U.S. Highway 30N and State Highway 37. Small quantities of coarse gravel have been obtained for local use from the pediment gravel at several localities and from gravel or poorly indurated conglomerate of the Starlight Formation. A large amount of Tertiary gravel has been removed from a pit at Pauline, in Arbon Valley.

\section{CRUSHED ROCK}

Basalt or Paleozoic carbonate rock of this area has not been used as a source of crushed rock to any great extent, but these rocks constitute a vast reserve of material that can be crushed, sized, and utilized for road surfacing or concrete aggregate. Most of the basalt of this area is dense, hard, and unweathered. 


\section{PUMICE AND TUFF}

Tuffaceous and pumiceous parts of the Walcott Tuff and the Starlight Formation might be suitable for abrasives or lightweight concrete aggregate. Very friable pure silicic tuff occurs locally in the lower member of the Starlight Formation in the Arbon quadrangle. The lower part of the Walcott Tuff is fairly pure silicic ash.

\section{DIATOMACEOUS CLAY}

Diatomaceous beds are present in the lower part of the Starlight Formation in the area of Starlight Creek, and the blocky clay layer in the American Falls Lake Beds contains about 70-percent diatoms. Diatomaceous earth is used extensively as fillers, filters, and abrasives, as well as in the manufacture of brick and ceramics.

\section{METALLIFEROUS DEPOSITS}

Although prospect pits, shafts, and drifts are found in several localities in the two-quadrangle area, and minor lead and silver has been reported in some of the prospects by local residents, there is no indication that any metalliferous ore was ever produced and shipped. A small occurrence of barite has been prospected in the $\mathrm{SE}^{1 / 4} \mathrm{NE}^{1 / 4}$ sec. 10, T. 8 S., R. 31 E., north of Pole Road. Small amounts of mercury reportedly were produced from prospects in the $\mathrm{SW}^{1 / 4}$ $\mathrm{NE}^{1 / 4}$ sec. 28 , T. 8 S., R. 31 E., but mercury minerals were not seen in the dump. Dumps at many other prospects were examined, and most appeared to contain only iron-stained brecciated rock typical of faults.

\section{PHOSPHATE ROCK}

Some thin beds, commonly less than 18 inches thick, in the lower part of the Manning Canyon Shale north of the road in Well Canyon are phosphatic and, locally, contain as much as 30-percent $\mathrm{P}_{2} \mathrm{O}_{5}$. This phosphatic rock is rusty brown and oolitic or pisolitic. Some of the shale also is phosphatic and contains about 30-percent $\mathrm{P}_{2} \mathrm{O}_{5}$. Similar phosphatic rock occurs in shaly siltstone of the lower member of the Deep Creek Formation in the NE $1 / 4 \mathrm{NE}^{1 / 4}$ sec. 3, T. 9 S., R. 33 E., but is only a few inches thick.

\section{MEASURED SECTIONS OF PALEOZOIC ROCKS}

SECTION 7.-Begins above fault breccia at southwest tip of ridge above road into Buck Canyon, in the NW1/4NW1/4 sec. 1, T. $10 \mathrm{~S} ., \mathrm{R} .31 \mathrm{E}$., and ends at top of hill, altitude about 7,750 feet, in the $N W^{1 / 4} S E^{1 / 4}$ sec. 31, T. 9 S., R. 32 E., Rockland quadrangle, Idaho

Top of measured section.

Oquirrh Formation (unit D, part):

Thickness

(feet)

Limestone, gray, sandy, weathers tan. Contains fusulinids and

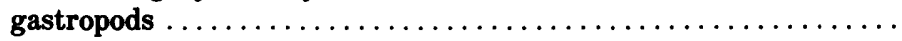


SECTION 7.-Begins above fault breccia at southwest tip of ridge above road into Buck Canyon, in the NW1/4NW $1 / 4$ sec. 1, T. $10 \mathrm{~S} .$, R. 31 E., and ends at top of hill, altitude about 7,750 feet, in the $N W^{1 / 4} S E^{1 / 4}$ sec. 31, T. 9 S., R. 32 E., Rockland quadrangle, Idaho-Continued

Thickness

(feet)

Chert, $\tan$ to gray, in layers $2-8$ in. thick $\ldots \ldots \ldots \ldots \ldots \ldots \ldots$

Limestone, gray to tan, silty and sandy to very sandy; weathers tan; interlayered locally with chert beds and a few sandstone layers. Some bioclastic limestone. Fusulinids abundant at many horizons ...

Limestone, gray to tan-gray, weathering tan to brown, with many gray cherty layers and nodules; bioclastic limestone at base .......

Chert, $\tan$ to gray; bedded in layers $1-6$ in. thick with interbeds of $\tan$ sandy limestone more abundant near top . . . . . . . . . .

Total unit D measured $\ldots \ldots \ldots \ldots \ldots \ldots \ldots \ldots \ldots \ldots$

Oquirrh Formation (unit C):

Limestone, gray to dark-gray, silty; weathers to rough surfaces; upper part almost a coquina of brachiopods and fossil hash ........

Limestone, gray to light-gray or tan, mostly tan-weathering; some slabby and platy; fusulinids in lower part .................

Limestone, cherty, slabby; tan to brown chert layers 1-5 in. thick, increase in abundance upward $\ldots \ldots \ldots \ldots \ldots \ldots \ldots \ldots \ldots$

Limestone, gray to light-gray or tan; mostly sandy; weathers light gray to tan; contains a few beds of coarse bioclastic limestone and locally minor chert; fusulinids, brachiopods, and bryozoa in lower

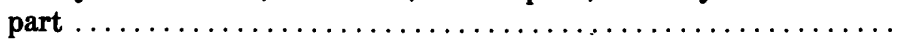

Conglomerate, chert and limestone granules in gray sandy limestone matrix, underlain by tan calcareous sandstone that forms ledge ....

Limestone, gray to dark-bluish-gray, mostly silty and sandy; weathers tan in upper part and mostly gray in the lower part; bioclastic layers in lower part; fusulinids, brachiopods, and corals in lower part .....

Conglomerate, chert granule to pebble, in limestone matrix; weathers

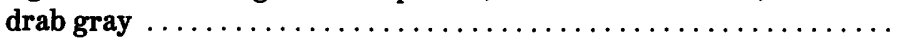

Limestone, dark-blue-gray; weathers blue gray; a layer of tan to pinkish-gray platy sandy limestone in lower part ............

Limestone, gray, mostly silty and sandy; weathers tan to gray. Zone of

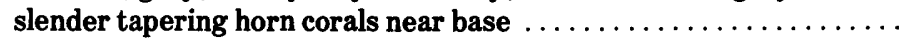

Limestone, dark-blue-gray to nearly black; lower third thin bedded, upper part massive; weathers light gray to sooty black; tan irregular chert balls at top $\ldots \ldots \ldots \ldots \ldots \ldots \ldots \ldots \ldots \ldots$

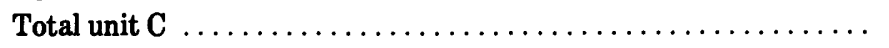

Oquirrh Formation (unit B):

Limestone, gray to light-gray, sandy to very sandy; weathers tan to gray; some nodules of gray, brown, and tan chert; fusulinids near top; large (Caninia?) corals near base and about $230 \mathrm{ft}$ above base ...

Total unit B measured

Oquirrh Formation (unit A):

Limestone, light-gray to gray or blue-gray; upper part silty and sandy; much bioclastic limestone; some chert . . . . . . . . . . . . . . .

Total unit A measured $\ldots \ldots \ldots \ldots \ldots \ldots \ldots \ldots \ldots \ldots$ 
SECTION 6.-Begins in saddle north of Water Canyon in the $N W^{1 / 4} N E^{1 / 4}$ sec. $26, T$. $9 S ., R .31 E$., and continues in secs. 23 and 24 to crest of divide, thence northward along divide in the $N W^{1 / 4} S E^{1 / 4}$ sec. 24 , except for the Manning Canyon Shale, which was measured north of Well Canyon, beginning in saddle near center of sec.

23, T. 9 S., R. 31 E., Rockland quadrangle, Idaho

Oquirrh Formation (unit B, part):

Thickness

(feet)

Limestone, gray to tan-gray, silty to sandy; weathers tan; $\tan$ and gray chert nodules in lower part; abundant large (Caninia?) corals in lower $20 \mathrm{ft}$.

Oquirrh Formation (unit A):

Limestone, light-gray to gray; silty in upper part; some silty and sandy patches and partings; local nodules and stringers of tan and gray chert especially in upper part; weathers tan to gray .........

Limestone, mostly gray, fine- to coarse-grained; some bioclastic layers; weathers light gray to tan; some chert nodules and stringers; corals and bryozoa in lower part . . . . . . . . . . . . . . . . .

Quartzite, light-gray; weathers tan; limy, fine grained; and sandy

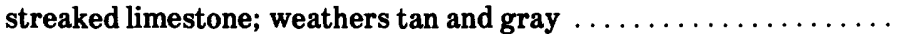

Limestone, light-gray to gray; silty in upper part, sandy in lower part; weathers light gray to tan; locally abundant tan chert in nodules,

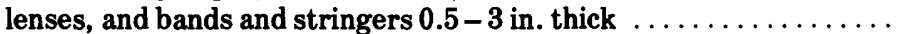

Limestone, gray, coarse-grained, and light-tan massive quartzite.

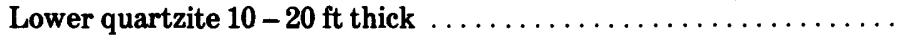

Total unit A measured $\ldots \ldots \ldots \ldots \ldots \ldots \ldots \ldots \ldots \ldots \ldots$

(This is probably a minimum thickness for $A$ because of faulting.)

Total Oquirrh Formation measured $\ldots \ldots \ldots \ldots \ldots \ldots \ldots$

Manning Canyon Shale:

Quartzite and sandstone, tan, and dark-gray shale and shaly argillite with a few interbeds of gray silty bioclastic limestone in upper part .

Limestone, gray to dark-gray, silty; weathers tan to purplish gray;

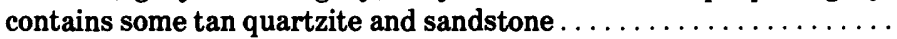

Sandstone, varicolored, calcareous to noncalcareous; interbedded with tan silty limestone, dark-gray shale, tan to purplish-gray siltstone, and minor bioclastic and conglomeratic limestone ............

Siltstone, tan to pinkish-gray, calcareous, and gray to tan silty limestone. Brachiopods common. ....................

Limestone, brownish-gray, with much fossil debris, and shaly argillite; some reddish-gray fine-grained sandstone and tan to pinkish-gray siltstone in upper part $\ldots \ldots \ldots \ldots \ldots \ldots \ldots \ldots \ldots \ldots \ldots$

Shale and shaly argillite, black; interbedded in upper part with brown argillaceous limestone and in central part with gray-green to brown quartzitic siltstone. A layer of oolitic phosphate rock, 6-18 in. thick, about $100 \mathrm{ft}$ above base $\ldots \ldots \ldots \ldots \ldots \ldots \ldots \ldots \ldots$

Quartzite, $\tan$ to olive-brown; contains some ferruginous sandstone and, in the lower part, some interbedded shale and rusty sandy

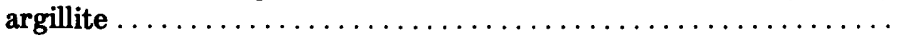

Shale, black; has interbedded argillite, olive-gray siltstone, and, in the lower part, some limestone and a few thin beds of tan quartzite and brown sandstone

Total Manning Canyon Shale. 
SECTION 6.-Begins in saddle north of Water Canyon in the NW1/4NE1/4 sec. 26, $T$. $9 S ., R .31 E$., and continues in secs. 23 and 24 to crest of divide, thence northward along divide in the $N W^{1 / 4} S E^{1 / 4}$ sec. 24, except for the Manning Canyon Shale, which was measured north of Well Canyon, beginning in saddle near center of sec.

23, T. 9 S., R. 31 E., Rockland quadrangle, Idaho-Continued

Thickness (feet)

Great Blue Limestone (upper limestone member):

Limestone, gray; weathers light gray; medium to coarse grained; a few scattered black chert nodules

Note: A fault here cuts out an unknown, but probably not large, amount of section.

Limestone, gray and dark-gray to black, fine-grained; weathers light gray; interbedded silty limestone and eoarse- to medium-grained limestone containing much fossiliferous debris. Some black chert and much black dolomite that resembles chert. . . . . . . . . . . . . .

Limestone, light-gray to tan, silty; has dark-gray cherty layers which become more abundant upward $\ldots \ldots \ldots \ldots \ldots \ldots \ldots \ldots \ldots \ldots$

Total upper limestone member

Great Blue Limestone (middle shale member):

Shale, black to brownish-gray or greenish-gray; has interbeds of brown sandy and argillaceous limestone in upper and middle part, and brown quartzite in the lower part. Abundant concretions of

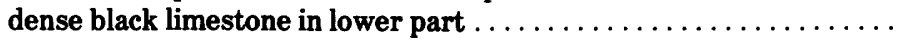

Total middle shale member measured

Great Blue Limestone (lower limestone member)-Not measured.

Base of section.

SeCTION 5.-Type section of the Deep Creek Formation begins about 100 feet northwest of bench mark 5,422 in the $N^{1 / 2}$ sec. 35, T. 9 S., R. 31 E., north side of Hunter Canyon, Rockland quadrangle, Idaho

Top of section in saddle $1,000 \mathrm{ft}$ southwest of peak 7,018 .

Great Blue Limestone (middle shale member):

Shale, and chert, black-Not measured.

Great Blue Limestone (lower limestone member):

Limestone, blue-gray to light-gray or tan, thick-bedded to massive, fine- to coarse-grained; chert as layers, stringers, and nodules; many large horn corals in upper part ...................

Shale, dark-gray; has interbeds of gray to blue-gray thin-bedded

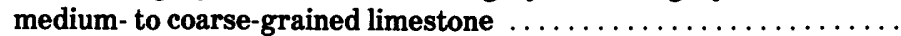

Limestone, gray to dark-gray and blue-gray, thick-bedded to massive, fine- to coarse-grained; chert lenses, nodules, and stringers mostly in lower two-thirds of unit; Gigantoproductid zone about $60 \mathrm{ft}$ above the base . . . . . . . . . . . . . . . . . . . . . . . . . . . .

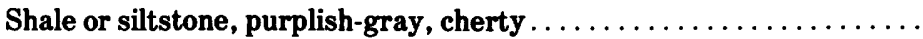

Limestone, dark-blue-gray to gray, thick-bedded; dark chert nodules and bands; many large horn corals . . . . . . . . . . . . . . . .

Total lower limestone member

Total Great Blue Limestone measured 
SECTION 5.-Type section of the Deep Creek Formation, begins about 100 feet northwest of bench mark 5,422 in the $N^{1 / 2}$ sec. $35, T .9 \mathrm{~S} ., R .31 \mathrm{E}$., north side of Hunter Canyon, Rockland quadrangle, Idaho-Continued

Deep Creek Formation (upper member):

Limestone, dark-gray, fine-grained; weathers blue gray; interbedded with blue-gray medium- to coarse-grained limestone ............

Limestone, gray to dark-gray and blue-gray; some silty and fine sandy partings; many black chert bands and layers especially in lower two-thirds......................................

Limestone, gray to pinkish-gray and greenish-gray, thin-bedded, platy; a little black chert . . . . . . . . . . . . . . . . . . . . . . . .

Limestone, gray to dark-gray and blue-gray; silty in lower part; some black chert in nodules and in bands as much as $1.5 \mathrm{ft}$ thick......... Total upper member $\ldots \ldots \ldots \ldots \ldots \ldots \ldots \ldots \ldots \ldots \ldots$

Deep Creek Formation (lower member):

Limestone, silty; interbedded with gray to dark-gray limestone; has a few interbeds of siltstone; $a$ few irregular bands of black chert .....

Siltstone, limy, and limestone, silty, light-gray to tan; weathers lightbrown to orange; thin bedded; a few nodules and bands of black chert

Limestone, silty, gray to black; a few purplish-gray beds . . . . . . . .

Shale and siltstone, light-grayish-brown; orange stain on some bedding planes; $a$ few thin chert layers $\ldots \ldots \ldots \ldots \ldots \ldots \ldots \ldots$

Total lower member $\ldots \ldots \ldots \ldots \ldots \ldots \ldots \ldots \ldots \ldots \ldots \ldots$.

Total Deep Creek Formation. . . . . . . . . . . . . . . .

Lodgepole Limestone (part):

Limestone, gray to black, fine-grained; weathers gray to light brownish gray; beds $2-12$ in. thick; some well-preserved corals and brachiopods

Dolomite, light-bluish-gray, fine sandy textured; a few bands and nodules of black chert in upper part; some fossil debris and small corals

Base of section not exposed.

Total Lodgepole Limestone measured

SECTION 4.-About 6 miles north of Pauline, in the SE1/4 sec. 11 and the $S W^{1 / 4}$ sec. 12, T. 9 S., R. 33 E., Arbon quadrangle, Idaho

Top of section about $400 \mathrm{ft}$ southwest of hill 5,951.

Lodgepole Limestone:

Limestone, dark-blue-gray-Not measured.

Beirdneau Formation:

Dolomite, light-bluish-gray to gray; some finely laminated; a few thin beds of $\tan$ quartzite and dolomitic sandstone $\ldots \ldots \ldots \ldots \ldots \ldots$

Quartzite, light-tan, fine-grained, with some dolomite sandstone .....

Total Beirdneau Formation 
SECTION 4.-About 6 miles north of Pauline, in the $S E^{1 / 4}$ sec. 11 and the $S W^{1 / 4}$ sec. 12, T. 9 S., R. 93 E., Arbon quadrangle, Idaho-Continued

Hyrum Dolomite:

Thickness (feet)

Dolomite, dark-gray to black; a few beds gray to light gray; fine to medium grained; some beds laminated. Amphipora in basal beds ...

Total Hyrum Dolomite 542

Laketown Dolomite:

Dolomite, light-gray to dark-gray; weathers light gray to gray; local

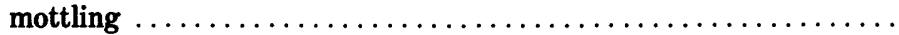

Dolomite, light-gray to light-tan, fine- to medium-grained; weathers

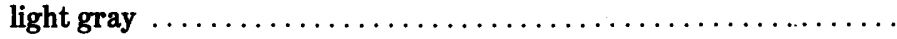

Total Laketown Dolomite

Section 3.-About 2 miles north of Pauline, in the SE $1 / 4$ sec. 35, T. 9 S., R. 33 E.

Fish Haven Dolomite (part):

Dolomite, mostly gray to dark-gray, fine- to medium-grained; mottled

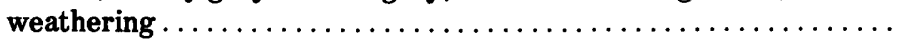

Delomite, dark-gray to gray, fine- to medium-grained; chert nodules and stringers mainly in the lower part. . . . . . . . . . . . . . . . .

Sandstone, $\tan$ to light-gray, very dolomitic $\ldots \ldots \ldots \ldots \ldots \ldots$

Total Fish Haven Dolomite measured $\ldots \ldots \ldots \ldots \ldots \ldots \ldots$

Swan Peak Quartzite

Quartzite, white, medium-grained, well-sorted-Not measured.

SECTION 2.-Begins at toe of spur an boundary between secs. 8 and 17, T. $8 S ., R$. 34 E., on Midnight Creek, Arbon quadrangle, Idaho

Partial section of Cambrian rocks.

Top of section on divide, about one-quarter mile east of quadrangle boundary.

St. Charles Formation (part):

Worm Creek Quartzite Member (part):

Note: At least several hundred feet more of quartzite are present, which could not be measured here.

Quartzite, tan, fine- to medium-grained; a few interbeds of tan dolomitic sandstone in lower part. ....................

Dolomite, gray to very light tan; weathers cream, sugary and sandy; in ledges $1-3 \mathrm{ft}$ thick . . . . . . . . . . . . . . . . . . . . . .

Sandstone, $\tan$ to pinkish-tan, fine- to coarse-grained, very slabby;

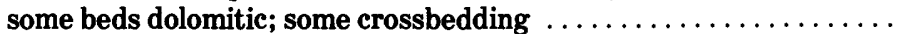

Dolomite, gray to dark-gray; weathers tan to gray; lower part silty and sandy . . . . . . . . . . . . . . . . . . . . . . . . .

Sandstone, $\tan$ and red, slightly calcareous, fine- to medium-grained; grades up into tan quartzite $\ldots \ldots \ldots \ldots \ldots \ldots \ldots \ldots \ldots \ldots \ldots$ Total Worm Creek Quartzite Member of St. Charles Formation measured 
SECTION 2.-Begins at toe of spur on boundary between secs. 8 and 17, T. 8 S., $R$. 34 E., on Midnight Creek, Arbon quadrangle. Idaho-Continued

Nounan Dolomite:

Dolomite, pinkish-gray to light-gray and grayish-tan, fine- to coarsegrained; some blue-gray limestone and thin brown chert seams.....

Thickness

(feet)

132

Limestone, pale-pink or grayish-pink and gray to light-gray, fine-

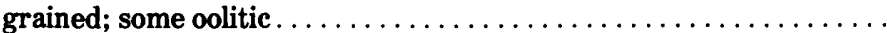

Note: Fault about here cuts out about $100 \mathrm{ft}$ of thin-bedded sandy limestone.

Sandstone, $\tan$, brown, and reddish-brown, slightly calcareous, fine-

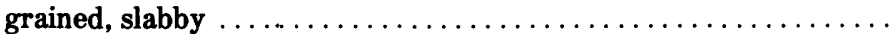

Limestone, blue-gray to gray with silty partings, some intraformational conglomerate in lower half, some finely oolitic; grades upward into sandy dolomite $\ldots \ldots \ldots \ldots \ldots \ldots \ldots \ldots$

Total Nounan Dolomite . . . . . . . . . . . . . . . . . . . . . . .

Bloomington Formation:

Limestone, varicolored pastel, with some intraformational conglomerate and interbedded micaceous siltstone and tannish-green shale; gray limestone in lower part $\ldots \ldots \ldots \ldots \ldots \ldots \ldots \ldots$

Shale, tannish-green, and thin-bedded tan fine-grained calcareous sandstone and siltstone and varicolored pastel limestone .........

Limestone, gray to blue-gray; has much intraformational conglomerate, interbedded with greenish-gray fine-grained limestone and tan to greenish-gray calcareous fine-grained sandstone, siltstone, and shale $\ldots \ldots \ldots \ldots \ldots \ldots \ldots \ldots \ldots \ldots$

Shale, tannish-green; interbedded with gray oolitic limestone, some intraformational conglomerate, and some tannish-green nodular

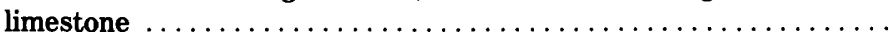

Limestone, blue-gray, thin-bedded, oolitic; $\tan$ and reddish-brown

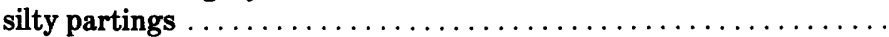

Argillite and siltstone, drab-green; a few beds of gray limestone in

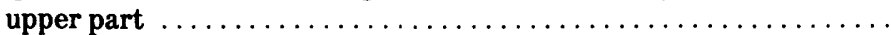

Limestone, gray, oolitic, and gray-green limestone, locally nodular, interbedded with greenish-tan siltstone and shaly siltstone ........

Shale, olive-drab, and some gray and greenish-gray limestone; some colitic; a little intraformational conglomerate $\ldots \ldots \ldots \ldots \ldots \ldots$

Quartzite, brown to reddish-brown, fine- to medium-grained, slabby; a few gray limestone interbeds in upper part . . . . . . . . . . . .

Shale, drab-green; some interbedded red-brown quartzite and sandstone

Limestone, blue-gray, platy; yellowish-tan silty partings and laminae. A few interbeds of oolitic limestone in upper part .............

Claystone and shaly argillite, olive-drab; some gray oolitic limestone, tan fine-grained sandstone, and green limestone nodules ........

Limestone, gray, oolitic; a few algal nodules about 0.5 in. in diameter .

Siltstone, greenish-tan, micaceous; some gray oolitic limestone and

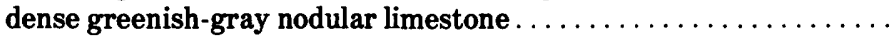

Limestone, blue-gray, oolitic; interbedded with some platy limestone

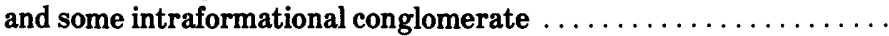

Siltstone and claystone, greenish-tan to olive, micaceous; some interbeds of blue-gray platy limestone $\ldots \ldots \ldots \ldots \ldots \ldots \ldots \ldots \ldots$

Total Bloomington Formation 
SECTION 2.-Begins at toe of spur on boundary between secs. 8 and 17, T. 8 S., $R$. 34 E., on Midnight Creek, Arbon quadrangle, Idaho-Continued

Elkhead Limestone (part):

Limestone, gray to blue-gray, locally oolitic; some yellowish-tan silty partings and laminae; some intraformational conglomerate .......

Total Elkhead Limestone measured $\ldots \ldots \ldots \ldots \ldots \ldots \ldots$

Base of section.

SECTION 1. $-N W^{1 / 4} N E^{1 / 4}$ sec. 7, T. 8 S., $R$. 34 E., northeast corner of Arbon quadrangle, Idaho

Thickness (feet)

Partial section of Cambrian rocks.

Top of section probably cut off by fault.

Gibson Jack Formation (member B):

Quartzite, light-tan to gray and brown, fine- to medium-grained; in

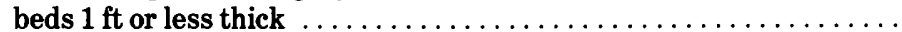

Total member B $\underline{115}$

115

Gibson Jack Formation (member A):

Argillite, olive-drab to brown, shaly; some beds micaceous; a few beds of reddish-brown quartzite $\ldots \ldots \ldots \ldots \ldots \ldots \ldots \ldots \ldots$

Siltstone, olive, gray-green, purplish, and tan; beds of tan to brown sandstone, tan shaly argillite, and a few beds of greenish micaceous

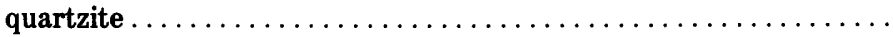

Quartzite and sandstone, tan to brown or reddish-brown; some beds of tan argillaceous siltstone .

Total member A

Camelback Mountain Quartzite-Not measured.

\section{REFERENCES CITED}

Anderson, A. L., 1928, Portland cement materials near Pocatello, Idaho: Idaho Bur. Mines and Geology Pamph. 28, 15 p.

1931, Geology and mineral resources of eastern Cassia County, Idaho: Idaho Bur. Mines. and Geology Bull. 14, 169 p.

Armstrong, F. C., 1953, Generalized composite stratigraphic section for the Soda Springs quadrangle and adjacent areas in southeastern Idaho, in Guide to the geology of northern Utah and southeastern Idaho: Intermtn. Assoc. Petroleum Geologists, 4th Ann. Field Conf., 1953.

Armstrong, F. C., and Cressman, E. R., 1963, The Bannock thrust zone, southeastern Idaho: U.S. Geol. Survey Prof. Paper 374-J, 22 p.

Armstrong, R. L., 1968, Sevier orogenic belt in Nevada and Utah: Geol. Soc. America Bull., v. 79 , no. 4 , p. 429-458.

Baker, A. A., 1947, Stratigraphy of the Wasatch Mountains in the vicinity of Provo, Utah: U.S. Geol. Survey Oil and Gas Inv. Prelim. Chart 30.

Benson, A. L., 1966, Devonian stratigraphy of western Wyoming and adjacent areas: Am. Assoc. Petroleum Geologists Bull., v. 50, no. 12, p. 2566-2603.

Bissell, H. J., 1939, Fusulinids as an aid in zoning the Oquirrh series of Utah: Utah Acad. Sci., Arts and Letters Proc., v. 16, p. 87-89. 
1959, Stratigraphy of the southern Oquirrh Mountains-Pennsylvanian system, in Geology of the southern Oquirrh Mountains and Fivemile PassNorthern Boulter Mountain area, Tooele and Utah Counties, Utah: Utah Geol. Soc. Guidebook to Geology of Utah, No. 14, p. 93-127.

Carr, W. J., and Trimble, D. E., 1961, Upper Paleozoic rocks in the Deep Creek Mountains, Idaho, in Short papers in the geologic and hydrologic sciences: U.S. Geol. Survey Prof. Paper 424-C, p. C181-C184.

1963, Geology of the American Falls quadrangle, Idaho: U.S. Geol. Survey Bull. 1121-G, 44 p.

Collier, A. J., and Cathcart, S. H., 1922, Possibility of finding oil in laccolithic domes south of the Little Rocky Mountains, Montana: U.S. Geol. Survey Bull. 736-F, p. 171-178.

Crittenden, M. D., Jr., 1961, Magnitude of thrust faulting in northern Utah, in Short papers in the geologic and hydrologic sciences: U.S. Geol. Survey Prof. Paper 424-D, p. D128-D131.

Crittenden, M. D., Jr., Schaeffer, F. E., Trimble, D. E., and Woodward, L. A., 1971, Nomenclature and correlation of some upper Precambrian and basal Cambrian sequences in western Utah and southeastern Idaho: Geol. Soc. America Bull., v. 82 , no. 3, p. 581-602.

Crosthwaite, E. G., 1957, Ground-water possibilities south of the Snake River between Twin Falls and Pocatello, Idaho: U.S. Geol. Survey Water-Supply Paper 1460-C, p. 99-145.

Disbrow, A. E., 1961, Geology of the Boulter Peak quadrangle, Utah: U.S. Geol. Survey Geol. Quad. Map GQ-141.

Dutro, J. T., Jr., and Sando, W. J., 1963, New Mississippian formations and faunal zones in Chesterfield Range, Portneuf quadrangle, southeast Idaho: Am. Assoc. Petroleum Geologists Bull., v. 47, no. 11, p. 1963-1986.

Gazin, C. L., 1935, Annotated list of Pleistocene Mammalia from American Falls, Idaho: Washington Acad. Sci. Jour., v. 25, no. 7, p. 297-307.

Gilluly, James, 1932, Geology and ore deposits of the Stockton and Fairfield quadrangles, Utah: U.S. Geol. Survey Prof. Paper 173, 171 p.

Hibbard, C. W., 1958, Summary of North American Pleistocene mammalian local faunas: Michigan Acad. Sci., Arts and Letters Papers, v. 43, p. 3-32.

Hopkins, M. L., 1951, Bison (Gigantobison) latifrons and Bison (Simobison) alleni in southeastern Idaho: Jour. Mammalogy, v. 32, no. 2, p. 192-197.

Hopkins, M. L., Bonnichsen, Robson, and Fortsch, David, 1969, The stratigraphic position and faunal associates of Bison (Gigantobison) latifrons in southeastern Idaho-A progress report: Tebiwa, v. 12 , no. 1, p. 1-8.

Kirkham, V. R. D., 1931, Snake River downwarp: Jour. Geology, v. 39, no. 5, p. $456-482$.

Kuno, Hisashi, 1960, High alumina basalt: Jour. Petrology, v. 1, no. 2, p. 121-125.

Love, J. D., 1956, New geologic formation names in Jackson Hole, Teton County, northwestern Wyoming: Am. Assoc. Petroleum Geologists Bull., v. 49, no. 8, p. 1899-1914.

Ludlum, J. C., 1942, Pre-Cambrian formations at Pocatello, Idaho: Jour. Geology, v. 50 , no. 1 , p. 85-95.

1943, Structure and stratigraphy of part of the Bannock Range, Idaho: Geol. Soc. America Bull., v. 54, no. 7, p. 973-986.

Malde, H. E., 1959, Fault zone along northern boundary of western Snake River Plain, Idaho: Science, v. 130, no. 3370, p. 272.

Mansfield, G. R., 1920, Geography, geology, and mineral resources of the Fort Hall Indian Reservation, Idaho, with a chapter on Water resources, by W. B. Heroy: U.S. Geol. Survey Bull. 713, 152 p. 


\section{GEOLOGY, ROCKLAND AND ARBON QUADRANGLES, IDAHO}

1927, Geography, geology, and mineral resources of part of southeastern, Idaho, with Descriptions of Carboniferous and Triassic fossils, by G. H. Girty: U.S. Geol. Survey Prof. Paper 152, 453 p.

1952, Geography, geology, and mineral resources of the Ammon and Paradise Valley quadrangles, Idaho: U.S. Geol. Survey Prof. Paper 238, 92 p.

Mansfield, G. R., and Ross, C. S., 1935, Welded rhyolitic tuffs in southeastern Idaho: Am. Geophys. Union Trans., 16th Ann. Mtg., Washington, D.C., 1935, p. 308-321.

Mapel, W. J., and Hail, W. J., Jr., 1959, Tertiary geology of the Goose Creek district, Cassia County, Idaho, Box Elder County, Utah, and Elko County, Nevada: U.S. Geol. Survey Bull. 1055-H, p. 217-254 [1960].

Maxey, G. B., 1958, Lower and Middle Cambrian stratigraphy in northern Utah and southeastern Idaho: Geol. Soc. American Bull., v. 69, no. 6, p. 647-687.

Moyle, R. W., 1959, Stratigraphy of the southern Oquirrh Mountains-Mississippian and Pennsylvanian rocks, in Geology of the southern Oquirrh Mountains and Fivemile Pass-Northern Boulter Mountain area, Tooele and Utah Counties, Utah: Utah Geol. Soc. Guidebook to Geology of Utah, no. 14, p. 59-92.

Mullens, T. E., and Izett, G. A., 1964, Geology of the Paradise quadrangle, Cache County, Utah: U.S. Geol. Survey Bull. 1181-S, 32 p.

Nockolds, S. R., 1954, Average chemical compositions of some igneous rocks: Geol. Soc. America Bull., v. 65, no. 10, p. 1007-1032.

Nolan, T. B., 1935, The Gold Hill mining district, Utah: U.S. Geol. Survey Prof. Paper 177, 172 p.

Nygreen, P. W., 1958, The Oquirrh formation-stratigraphy of the lower portion in the type area and near Logan, Utah: Utah Geol. Mineralog. Survey Bull. $61,67 \mathrm{p}$.

Olson, R. H., 1956, Geology of Promontory Range, in Geology of parts of northwestern Utah: Utah Geol. Soc. Guidebook to Geology of Utah, no. 11, p. 41-75.

Oriel, S. S., 1965a, Brigham, Langston, and Ute Formations in Portneuf Range, southeastern Idaho, in Abstracts for 1964: Geol. Soc. America Spec. Paper 82, p. 341.

1965, Preliminary geologic map of the SW $1 / 4$ of the Bancroft quadrangle, Bannock and Caribou Counties, Idaho: U.S. Geol. Survey Mineral Inv. Field Studies Map MF-299.

Piper, A. M., 1924, Possibilities of petroleum in Power and Oneida Counties, Idaho: Idaho Bur. Mines and Geology Pamph. 12, 24 p.

Poulson, E. N., Nelson, L. B., and Poulson, A. E., 1943, Soil survey of the BlackfootAberdeen area, Idaho: U.S. Dept. Agriculture, Bur. Plant Industry, ser. 1937, no. $6,111 \mathrm{p}$.

Powers, H. A., 1960, A distinctive chemical characteristic of Snake River basalts of Idaho, in Short papers in the geological sciences: U.S. Geol. Survey Prof. Paper 400-B, p. B298.

Richardson, G. B., 1913, The Paleozoic section in northern Utah: Am. Jour. Sci., 4th ser., v. 36, p. 406-416.

1941, Geology and mineral resources of the Randolph quadrangle, UtahWyoming: U.S. Geol. Survey Bull. 923, 54 p.

Roberts, R. J., Crittenden, M. D., Jr., Tooker, E. W., Morris, H. T., Hose, R. K., and Cheney, T. M., 1965, Pennsylvanian and Permian basins in northwestern Utah, northeastern Nevada, and south-central Idaho: Am. Assoc. Petroleum Geologists Bull., v. 49, no. 11, p. 1926-1956.

Ross, C. P., 1947, Geology of the Borah Peak quadrangle, Idaho: Geol. Soc. America Bull., v. 58, no. 12 , pt. 1, p. 1085-1160. 
1961, Geology of the southern part of the Lemhi Range, Idaho: U.S. Geol. Survey Bull. 1081-F. p. 189-260.

1962, Upper Paleozoic rocks in central Idaho: Am. Assoc. Petroleum Geologists Bull., v. 46, no. 3, p. 384-387.

Ross, R. J., Jr., 1951, Stratigraphy of the Garden City formation in northeastern Utah, and its trilobite faunas: Yale Univ. Peabody Mus. Nat. History Bull. $6,161 \mathrm{p}$.

Rubin, Meyer, and Alexander, Corrinne, 1960, U.S. Geological Survey radiocarbon dates, V: Am. Jour. Sci., Radiocarbon Supp., v. 2, p. 129-185.

Sando, W. J., 1967, Mississippian depositional provinces in the northern Cordilleran region, in Geological Survey research 1967: U.S. Geol. Survey Prof. Paper 575-D, p. D29-D38.

Sando, W. J., and Dutro, J. T., Jr., 1960, Stratigraphy and coral zonation of the Madison group and Brazer dolomite in northeastern Utah, western Wyoming, and southwestern Montana, in Overthrust belt of southwestern Wyoming and adjacent areas: Wyoming Geol. Assoc. Guidebook, 15th Ann. Field Conf., 1960 , p. 117-126.

Sando, W. J., Mamet, B. L., and Dutro, J. T., Jr., 1969, Carboniferous megafaunal and microfaunal zonation in the northern Cordillera of the United States: U.S. Geol. Survey Prof. Paper 613-E, 29 p.

Schultz, C. B., Lueninghoener, G. C., Frankforter, W. D., 1951, A graphic resume of the Pleistocene of Nebraska (with notes on fossil mammalian remains): Nebraska Univ. State Mus. Bull., v. 3, no. 6, 41 p.

Scott, G. R., and Lindvall, R. M., 1970, Geology of new occurrences of Pleistocene bisons and peccaries in Colorado, in Geological Survey research 1970: U.S. Geol. Survey Prof. Paper 700-B, p. B141-B149.

Smith, R. L., 1960, Zones and zonal variations in welded ash flows: U.S. Geol. Survey Prof. Paper 354-F, p. 149-159 [1961].

Spurr, J. E., 1895, Economic geology of the Mercur mining district, Utah, with introduction by S. F. Emmons: U.S. Geol. Survey 16th Ann. Rept., pt. 2, p. 343-455.

Staatz, M. H., and Carr, W. J., 1964, Geology and mineral deposits of the Thomas and Dugway Ranges, Juab and Tooele Counties, Utah: U.S. Geol. Survey Prof. Paper 415, $188 \mathrm{p}$.

Stearns, H. T., Crandall, Lynn, and Steward, W. G., 1938, Geology and groundwater resources of the Snake River Plain in southeastern Idaho: U.S. Geol. Survey Water-Supply Paper 774, 268 p. [1939].

Stearns, H. T., and Isotoff, Andrei, 1956, Stratigraphic sequence in the Eagle Rock volcanic area near American Falls, Idaho: Geol. Soc. America Bull., v. 67, no. 1, p. 19-34.

Thompson, M. L., Verville, G. J., and Bissell, H. J., 1950, Pennsylvanian fusulinids of the south-central Wasatch Mountains, Utah: Jour. Paleontology, v. 24, no. 4, p. 430-465.

Tooker, E. W., and Roberts, R. J., 1970, Upper Paleozic rocks in the Oquirrh Mountains and Bingham mining district, Utah, with a section on Biostratigraphy and correlation, by Mackenzie Gordon, Jr., and H. M. Duncan: U.S. Geol. Survey Prof. Paper 629-A, 76 p.

Trimble, D. E., 1976, Geology of the Michaud and Pocatello quadrangles, Bannock and Power Counties, Idaho: U.S. Geol. Survey Bull. 1400 (in press).

Trimble, D. E., and Carr, W. J., 1961, Late Quaternary history of the Snake River in the American Falls region, Idaho: Geol. Soc. America Bull., v. 72, no. 12, p. 1739-1748. 


\section{GEOLOGY, ROCKLAND AND ARBON QUADRANGLES, IDAHO}

U.S. Geological Survey, 1964, Geological Survey research 1964: U.S. Geol. Survey Prof. Paper 501-A, 367 p.

Walcott, C. D., 1908, Nomenclature of some Cambrian Cordilleran formations, No. 1 of Cambrian geology and paleontology: Smithsonian Misc. Colln., v. 53, p. 1-12.

Wilcox, R. E., 1944, Rhyolite-basalt complex on Gardner River, Yellowstone Park, Wyoming: Geol. Soc. America Bull., v. 55, no. 9, p. 1047-1079.

Williams, J. S., 1948, Geology of the Paleozoic rocks, Logan quadrangle, Utah: Geol. Soc. America Bull., v. 59, no. 11, p. 1121-1163.

Yochelson, E. L., 1961, Occurrences of the Permian gastropod Omphalotrochus in northwestern United States, in Short papers in the geologic and hydrologic sciences, Art. 100: U.S. Geol. Survey Prof. Paper 424-B, p. B237-B239.

Youngquist, W. L., and Haegele, J. R., 1955, Fusulinid-bearing rocks in Sublett Range, southern Idaho: Am. Assoc. Petroleum Geologists Bull., v. 39, no. 10, p. 2078-2090. 


\section{INDEX}

[Italic page numbers indicate major references]

$\mathbf{A}$

Acknowledgments

Aberdeen terrace deposits

Alokistocare

Age, Aberdeen terrace deposits ..........

American Falls

Atokan

basalts $\ldots \ldots \ldots \ldots \ldots \ldots \ldots \ldots \ldots$

Beirdneau Formation

Big Hole Basalt . . . . . . . . . . . .

Bloomington Formation ............

boulder bars

Camelback Mountain Quartzite .......

Cedar Butte Basalt .

Chesterian

Deep Creek Formation . . . . . . . . .

dune sand

Elkhead Limestone

faults outlining Snake River Plain ....

Fish Haven Dolomite .

Garden City Formation

Gibson Jack Formation .

Great Blue Limestone

Hyrum Dolomite . ................

Laketown Dolomite ...............

Little Creek Formation .

Lodgepole Limestone

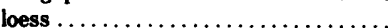

lower member, Starlight Formation...

Manning Canyon Shale

Massacre Volcanies

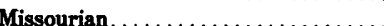

Morrowan ....................

Nounan Dolomite .

Oquirrh Formation ...............

older alluvium .

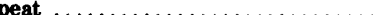

pediment gravel

Raft Formation.

Sunbeam

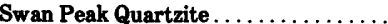

Starlight Formation.

thrust faults

travertine ...................

tuff of Arbon Valley, Starlight Formation

upper member, St. Charles Formation.

Starlight Formation. ...........

Virgilian.

vitrophyre $\ldots \ldots \ldots \ldots \ldots \ldots \ldots \ldots$

Walcott Tuff, radiometric dates ......

Wolfcampian ...................

Worm Creek Quartzite Member, St.

Charles Formation ..........

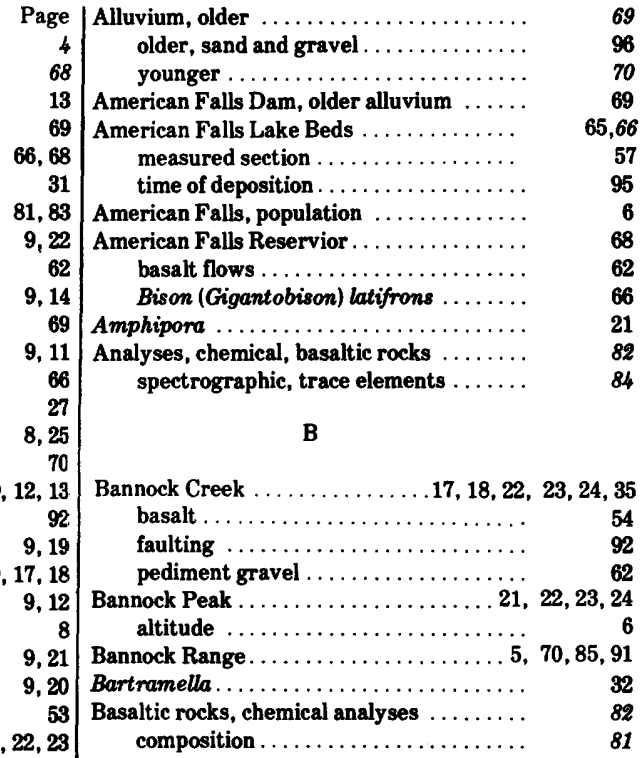

Basin-and-range faults $\ldots \ldots \ldots \ldots \ldots \ldots \ldots, 85,91,92$

40 Basin and Range physiographic province,

8,29

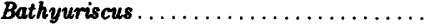
structural boundary

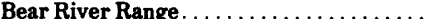

Beedeina .......................

Bedrock, exposed in mountainous areas ... 6

$\mathbf{9 , 1 5}$ Beirdneau Formation $\ldots \ldots \ldots \ldots \ldots \ldots \ldots, \mathbf{9 , 2 0 , 2 2}$

8, 31 measured section $\ldots \ldots \ldots \ldots \ldots \ldots \ldots, 101$

Bibliography ..................... 104

68 Big Hole Basalt $\ldots \ldots \ldots \ldots \ldots \ldots \ldots \ldots 62,80,82,95$

61,62 Bison (Gigantobison) latifrons ........ 66,67

61 Black Pine Range . . . . . . . . . . . . .

Blackrock Limestone ................. 10

65 Blacksmith Limestone.............. 12

9, 19 Blind Spring Creek, tuff of Arbon Valley ... .

43 Bloomington Formation $\ldots \ldots \ldots \ldots \ldots \ldots, 9,13$

88,89 measured section . . . . . . . . . . . . 103

63,64 Boulder bars . . . . . . . . . . . . . . 69

Bowen Canyon $\ldots \ldots \ldots \ldots \ldots \ldots \ldots \ldots \ldots \quad 34,91$

38 Bradyina ...................... 32

17 Brazer Limestone $\ldots \ldots \ldots \ldots \ldots \ldots \ldots \ldots \quad$ 27, 28

40 Brigham Quartzite ............... 10,11

31 Buck Canyon measured section ......... 97, 98

40 fusulinid determinations .......... 5

50 Bulimnea sp. .................. $42, \mathbf{4 5}$

31 Bulimulus, n. sp. a ............... 42

n. sp. b. . . . $\ldots \ldots \ldots \ldots \ldots \ldots \ldots \ldots, \quad 42$

16 Burgess Shale $\ldots \ldots \ldots \ldots \ldots \ldots \ldots \ldots \ldots, \quad 12$ 
Cambrian System...................

Camelback Mountain ................

Camelback Mountain Quartzite geologic history.$\ldots \ldots \ldots \ldots \ldots \ldots$

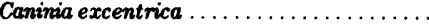
torquia.

Carinifex newberri.

Cascade Range, basalts .

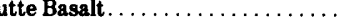

composition . . . . . . . . . . . . . .

dammed the river. . . . . . . . . . . . .

petrography $\ldots \ldots \ldots \ldots \ldots \ldots \ldots$

Cedar Butte eruption . . . . . . . . . . . . .

Cedar Ridge, Oquirrh Formation .........

Charleston thrust. . . . . . . . . . . . . . .

Chesterfield Range .................

Clay, diatomaceous, economic resource ....

Climate

Cold Creek

Columbia Plateaus physiographic provir

Columbia Piver

Composition, basaltic rocks silicic rocks

Conglomerate

Conglomerate lenses, upper member, Starlight Formation. ........

Contacts, Beirdneau Formation .......... Bloomington Formation ........... Camelback Mountain Quartzite ....... Deep Creek Formation . . . . . . . . . . . Elkhead Limestone ...............

Fish Haven Dolomite . . . . . . . . . .

Gibson Jack Formation . . . . . . . . . .

Hyrum Dolomite ................ Laketown Dolomite . . . . . . . . . . . .

Lodgepole Limestone .............

Manning Canyon Shale .............

Massacre Volcanics . . . . . . . . . . .

Neeley Formation $\ldots \ldots \ldots \ldots \ldots \ldots$

Nounan Dolomite . . . . . . . . . . . . . .

Starlight Formation.

Sunbeam Formation .............. upper member, St. Charles Formation. Walcott Tuff

Worm Creek Quartzite Member, St. Charles Formation ..........

Crushed rock, economic resource ........ Crystal Creek

D

Deep Creek Formation

$7,8,22,24$ type section

100,101

Deep Creek Mountains

$5,22,23$

altitude of crest

fault system

Great Blue Limestone

$25,26,27$

lower member, Starlight Formation. . .

Manning Canyon Shale

Oquirrh Formation ...........29,

structure

$29,30,31,32$

travertine

$85,88,89$

Walcott Tuff
$62,68,64$
34

East Fork Rock Creek, faults . . . . . springs $\ldots \ldots \ldots \ldots \ldots \ldots \ldots \ldots$ travertine $\ldots \ldots \ldots \ldots \ldots \ldots \ldots$

Economic resources . . . . . . . . . . . . . . . .

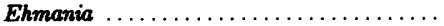

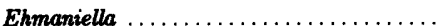

Elkhead Limestone..$\ldots \ldots \ldots \ldots \ldots \ldots$

measured section

Elkhead Ranch . . . . . . . . . . . . . . .

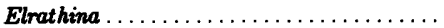

\section{F}

Faberophyllum.

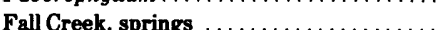

Faults, displacement in Tertiary rocks.....

Massacre Volcanics
Page

25

20

27

67

61

68

66

22

69

10

65

24

70

19

17

11

25

71

20

23

64

34

28

35,36

42

44

14,15

29,30

62

56

39

33,43

64

18

63

46,47

16

39

68

15

70

55, 79

91

9196

63

95

13

13

$9,10,12$

104

12

13

26

91

91

93 


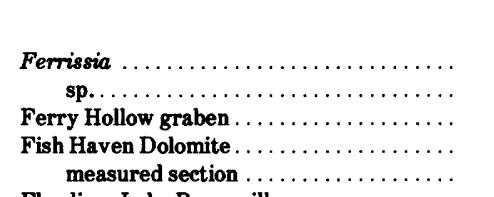

looding, Lake Bonneville . .

. 3, $19,43,89$

Fort Hall Indian Reservation

Fossaria dalli.

Fossils, Aberdeen terrace deposits

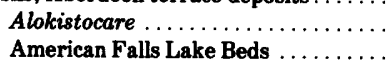

Amphipora ...................

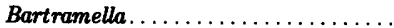

Bathyuriscus . . . . . . . . . . . . . .

Beedeina ...................

Beirdneau Formation

Bison (Gigantobison) latifrons . . . . . . latifrons.

Bradyina

Bulimnea sp.

Bulimulus n.

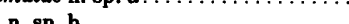

n. sp. b. . . . . . . . . . . .

Camelback Mountain Quartzite .......

Caninia excentrica ................ torquia . . . . . . . . . . . . .

Carinifex newberri. .............. determination acknowledgements ....

Dimegelasma eurkensis . ...........

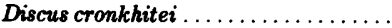
shimeki cockerelli. . . . . . . . . .

Ehmania

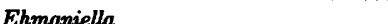

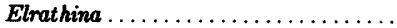

Faberophyllum.

Ferrissia

Fish Haven Dolomite.

Fossaria dalli.

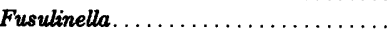

Garden City Formation .............

Gastrocopta (Albinula), n. sp. ........

Gibson Jack Formation . . . . . . . . . .

Great Blue Limestone ..............

Gyraulus circumstriatus ...........

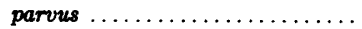

Hawaïa minuscula . . . . . . . . . . . . . .

Helisoma anceps . . .............. subcrenatum .................

Hipparion . . . ...............

Hunter Canyon . . . . . . . . . . . . .

Hydrobïidae ...................

Hyrum Dolomite..$\ldots \ldots \ldots \ldots \ldots \ldots$

Inflatia sp.

Kansanella. . . . . . . . . . . . . . . .

Laketown Dolomite ...............

Lithoglyphus fuscus. . . . . . . . . . .

$$
\text { n. sp. }
$$

Little Creek Formation . . . . . . . . . .

Lodgepole Limestone

loess $\ldots \ldots \ldots \ldots \ldots \ldots \ldots \ldots \ldots$

lower member, Starlight Formation. .

Madison Zone $\mathrm{C}_{1} \ldots \ldots \ldots \ldots \ldots \ldots$

Madison Zones $\mathrm{C}_{2}$ and $\mathrm{D} \ldots \ldots \ldots \ldots$

Manning Canyon Shale .............

Massacre Volcanics

Megatylopus sp.
Fossils-Continued

67,68

42,45

42

42

11

27

31, 32 middle member, Starlight Formation. .

Naraoia

Neeley Formation.$\ldots \ldots \ldots \ldots \ldots \ldots$

Nounan Dolomite . . . . . . . . . . . .

older alluvium . . . . . . . . . . . . . .

Olenellus

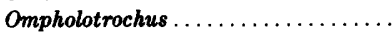

Oquirrh Formation $\ldots \ldots \ldots \ldots \ldots \ldots$

Oreohelix sp....................

Oreohelix strigosa depressa .........

Ovatia sp.

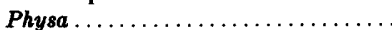

n. sp. $\ldots \ldots \ldots \ldots \ldots \ldots \ldots \ldots \ldots$

sp..

Pisidium compressum .............

Planobarius, n. sp. a

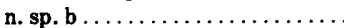
spp.

Page

35

12

45

15

69

12

32

31

42

61

27

67

42

42,45

61,67

42,45

42

45

42

Pliomastodon ...................... $\quad \mathbf{4 1}$

Promenetus exacuous .............. umbilicatellus $\ldots \ldots \ldots \ldots \ldots \ldots \ldots, 42, \mathbf{4 5}, \mathbf{6 7}$

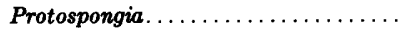

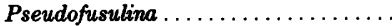

Pseudofusulinella.................

Pseudoschwagerina ..............

Psidium spp.

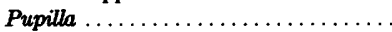

muscorum $\ldots \ldots \ldots \ldots \ldots \ldots$

Raft Formation . . . . . . . . . . . .

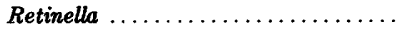

Schwagerina. . .

Solenopleura . . . . . . . . . . . . . . .

Sphaerium sp. a . . . . . . . . . . sp. b...................... striatinum $\ldots \ldots \ldots \ldots \ldots \ldots \ldots$

Spirifer pellaensis $\ldots \ldots \ldots \ldots \ldots \ldots$

Stagnicola albiconica .............. caperata................... palustris....................

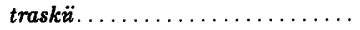
n. sp. sp. a $\ldots \ldots \ldots \ldots \ldots \ldots \ldots \ldots \ldots, 61,67$ sp. b $\ldots \ldots \ldots \ldots \ldots \ldots \ldots \ldots \ldots \quad 61,67$ sp................ 42

Succinea. . . . . . . . .

Sunbeam Formation . . . . . . . . . 65

Swan Peak Quartzite .............. $\quad 19$

travertine $\ldots \ldots \ldots \ldots \ldots \ldots \ldots \ldots \ldots, \quad 63$

Triticites ................. $\quad 32$

upper member, St. Charles Formation. Starlight Formation.

40,42

61,67

Vallonia cyclophorella .............. gracilicosta . . . . . . . . . . . .

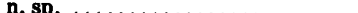

Valvata humeralis $\ldots \ldots \ldots \ldots \ldots \ldots, 42,45,61,67$ utahensis .............. $\quad 61,67$

Vertigo gouldii ................. 67 spp................... 42

Walcott Tuff ................ $\quad \mathbf{5 0}$

Wedekindellina............... 32

Worm Creek Quartzite Member ...... $\quad 16$

Zone F . . . . . . . . .

Zone K ................... 27

Zonitoides arboreus.............. 67 
Fusulinilla

G

Garden City Formation .................

Gastrocopta (Albinula), n. sp. ..........

Geography.

Geologic history ...................

Goose Creek, Starlight Formation ........

Gibson Jack Creek .................

Gibson Jack Formation . . . . . . . . . . . measured section

Girvanella ........................

Grandview terrace deposits ............

Gravel .........................

Gravity gradient $\ldots \ldots \ldots \ldots \ldots \ldots \ldots$

Gravity sliding, large-displacement .......

Great Blue Limestone . . . . . . . . . . 7 , measured section.$\ldots \ldots \ldots \ldots \ldots \ldots$

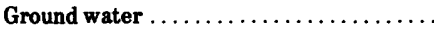

Gyraulus circumstriatus parvus

$\mathbf{H}$

Hawä̈a minuscula .................. Heavy minerals, distribution . . . . . . . . . .

Helisoma anceps ......................

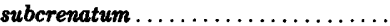

Highway access $\ldots \ldots \ldots \ldots \ldots \ldots \ldots \ldots$

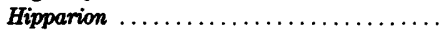

History, geologic $\ldots \ldots \ldots \ldots \ldots \ldots \ldots \ldots$

Howard Flat.

travertine $\ldots \ldots \ldots \ldots \ldots \ldots \ldots \ldots$

Humbug Formation $\ldots \ldots \ldots \ldots \ldots \ldots \ldots$

Hunter Canyon ................. 20, 24, 25 faults...

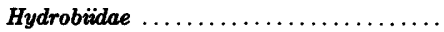

Hyrum Dolomite

measured section

\section{$\mathbf{I}, \mathbf{J}, \mathbf{K}$}

Indian Springs, travertine

Inflatia sp.

Intrusive rocks, Starlight Formation ......

Janies Nipple, Cedar Butte Basalt

Kansanella.

\section{L}

Lake Bonneville

Laketown Dolomite . . . . . . . . . . . . . . . measured section ................

Lamb Dolomite . . . . . . . . . . . . . . . . . .

Langston Limestone .................

Lithoglyphus fuscus . . . . . . . . . . . .

n. sp. . . . . . . . . . . .

Lithology, American Falls Lake Beds . . \begin{tabular}{|c|} 
Page \\
$\mathbf{3 1}, \mathbf{3 2}$
\end{tabular}

Beirdneau Formation . . . . . . . . . 9, 22, 101

Big Hole Basalt . . . . . . . . . . 62

Bloomington Formation $\ldots \ldots \ldots \ldots \ldots, 9,13,103$

Camelback Mountain Quartzite ....... $\quad 9,11$

Cedar Butte Basalt. . . . . . . . . . . 65

Deep Creek Formation . . . . . . . 8, 24, 100, 101

dune sand $\ldots \ldots \ldots \ldots \ldots \ldots \ldots \ldots, \quad 70$

Elkhead Limestone $\ldots \ldots \ldots \ldots \ldots \ldots .9,12,13,104$

Fish Haven Dolomite . . . . . . . . . . 9, 19, 102

Garden City Formation . . . . . . . . . . 9, 17

Gibson Jack Formation . . . . . . . . . . 9, 104 member A . . . . . . . $11 \ldots \ldots \ldots \ldots, \ldots$ members $B$ and $C \ldots \ldots \ldots \ldots \ldots, \quad 12$

Great Blue Limestone $\ldots \ldots \ldots \ldots \ldots 8,25,26,100$

Hyrum Dolomite $\ldots \ldots \ldots \ldots \ldots \ldots \ldots$ 9, 21, 102

Laketown Dolomite . . . . . . . . . . . . . . 9, 20, 102

Little Creek Formation . . . . . . . . . 51, 52

Lodgepole Limestone. . . . . . . . . 8,22, 23, 101

loess ..................... 64

lower member, Starlight Formation... 34

Manning Canyon Shale ........... 8, 28, 99 middle member, Starlight Formation.. $\quad \mathbf{3 5 , 3 6}$

Neeley Formation . . . . . . . . . . . 4

Nounan Dolomite ............... 9, 15, 103

Oquirrh Formation . . . . . . . . 8, 30, 97, 98, 99

Raft Formation ................ 58, 59, 60

St. Charles Formation . . . . . . . . . . 9

Sunbeam Formation ............. 64

Swan Peak Quartzite . ............ 9, 18

upper member, St. Charles Formation . $\quad 16$

Starlight Formation . . . . . . . . $\quad 39$

Walcott Tuff $\ldots \ldots \ldots \ldots \ldots \ldots \ldots \ldots, \quad 46$

Worm Creek Quartzite Member, St.

Charles Formation . . . . . 9, 15, 102

Little Creek Formation . . . . . . . . . . $\ldots, \quad \mathbf{3 9}, \mathbf{5 1}$

faults $\ldots \ldots \ldots \ldots \ldots \ldots \ldots \ldots \ldots, \quad 92$

measured sections $\ldots \ldots \ldots \ldots \ldots \ldots \ldots, 52,59,78$

Little Creek Formation, petrography $\ldots \ldots \quad \boldsymbol{7 7}, 78$

travertine overlying $\ldots \ldots \ldots \ldots \ldots \ldots, \quad 62$

Little Flat Formation $\ldots \ldots \ldots \ldots \ldots \ldots \ldots \quad \mathbf{2 4 , 2 5}$

Location of study ares.
Lodgepole Limestone

Loess

measured section $\ldots \ldots \ldots \ldots \ldots \ldots \ldots$

Long Trail Shale Member.............

Lower member, Starlight Formation ....... Starlight Formation, composition of silicic rocks ............. petrography..$\ldots \ldots \ldots \ldots \ldots \ldots$

\section{$7,8,22$}

101

$6,64,66$

25

34

86

\section{M}

Manning Canyon Shale $.7,8,22,25,27$

measured section

Massacre Rocks vent area $\ldots \ldots \ldots \ldots \ldots \ldots$

Massacre Volcanies ............... $\mathbf{5 1 , 5 4}$ basalt flows $\ldots \ldots \ldots \ldots \ldots \ldots \ldots \ldots 81, \mathbf{8 2}, \mathbf{8 3}, \mathbf{9 2}$ measured section $\ldots \ldots \ldots \ldots \ldots \ldots \ldots . \quad 78$ petrography $\ldots \ldots \ldots \ldots \ldots \ldots \ldots \ldots \ldots, \quad 79$ travertine $\ldots \ldots \ldots \ldots \ldots \ldots \ldots \ldots, \quad 63$

Measured sections, American Falls Lake Beds and Raft Formation .... $\quad 57$ Beirdneau Formation ............. 101 Bloomington Formation .......... 103 
Measured sections-Continued

Buck Canyon .

Deep Creek Formation, type section

Elkhead Limestone . . . . . . . . . . . . . . .

Fish Haven Dolomite . . . . . . . . . . . .

Gibson Jack Formation

Great Blue Limestone .

Little Creek Formation . . . . . . . . . . .

Lodgepole Limestone . . . . . . . . . . . .

Manning Canyon Shale

Massacre Volcanics . . . . . . . . . . .

Nounan Dolomite. .

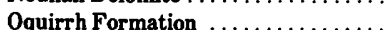

Paleozoic rocks . . . . . . . . . . . . . .

Raft Formation.

St. Charles Formation, Worm Creek Quartzite Member ..........

Walcott Tuff ................... in lower Ferry Hollow ...........

Water Canyon. . . . . . . . . . . . . . .

Megatylopus sp...................

Mercur mining district $\ldots \ldots \ldots \ldots \ldots \ldots$

Metalliferous deposits, economic resource

Michaud Gravel

Middle member, Starlight Formation ....

Midnight Creek ....................

Mississippian and Pennsylvanian Systems

Mississippian rocks

Mississippian System ...............

Mollys Nipple, faulting . . . . . . . . . . . tuff of Arbon Valley .

Monroe Canyon Formation .

Moonshine Creek .

\section{$\mathbf{N}, \mathbf{O}$}

Naraoia

Neeley Formation petrography

North Fork Pocatello Creek . . . . . . . . .

Nounan Dolomite . . . . . . . . . . . . . . . measured section

Olenellus

Ompholotrochus

measured sections

Oquirrh Mountains, correlated with Mississippian, Pennsylvanian, and Permian rocks.

Great Blue Limestone . . . . . . . . . . . Manning Canyon Shale

Ordovician rocks, Fish Haven Dolomite.... Garden City Formation . . . . . . . . . . Swan Peak Quartzite. . . . . . . . . . .

Ordovician System. . . . . . . . . . . . Oreohelix sp.

strigosa depressa . . . . . . . . . .

Ovatia sp.

\section{$\mathbf{P}$}

Paleozoic rocks, Cedar Ridge ............ formations exposed in area

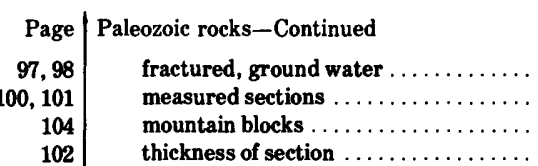

Page

96

97

85

7

Pediment gravel . . . . . . . . . . . . . .

100 Pennsylvanian and Permian Systems . . . . . .

102 Pennsylvanian rocks . . . . . . . . . .

52, 53 Permian rocks, Oquirrh Formation, unit D.
101

99

97, 98

97

59

102
Pete Lish Canyon, travertine. . . . . . . .

Petrography ................ Big Hole Basalt . . . . . . . . . . . boulder bars $\ldots \ldots \ldots \ldots \ldots \ldots \ldots \ldots$ Cedar Butte Basalt. . . . . . . . . . . . Little Creek Formation . . . . . . . . . . . lower member, Starlight Formation . . Massacre Volcanics . . . . . . . . 54, 78, 79 middle member, Starlight Formation . . Neeley Formation .............. older alluvium . . . . . . . . . . . . Starlight Formation. . . . . . . . . . . tuff of Arbon Valley, Starlight Formation ............

Walcott Tuff . . . . . . . . . . . . .

Phenocryst composition $\ldots \ldots \ldots \ldots \ldots \ldots$

Phosphate rock, economic resource ...... Physa .................... n. sp. $\ldots \ldots \ldots \ldots \ldots \ldots \ldots \ldots \ldots \ldots$

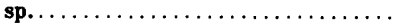

Pioche Shale $\ldots \ldots \ldots \ldots \ldots \ldots \ldots \ldots$

Pisidium compressum . . . . . . . . . spp.

Planorbarius, n. sp. a $\ldots \ldots \ldots \ldots \ldots \ldots \ldots$ n. sp. b. . . . . . . . . . . . . Planorbidae $\ldots \ldots \ldots \ldots \ldots \ldots \ldots \ldots \ldots \ldots$

Pleistocene tuff, composition of silicic rocks

Pliomastodon .................

Population, American Falls . . . . . . . . Pocatello ................. Rockland ................

Portneuf Range $\ldots \ldots \ldots \ldots \ldots \ldots \ldots$

Precipitation $\ldots \ldots \ldots \ldots \ldots \ldots \ldots \ldots$

Promenetus exacuous .............. umbilicatellus .

Promontory Mountains . . . . . . . . . .

Pseudofusulinella ................

Pseudoschwagerina .............. 32

Psidium spp. . . . . $\ldots \ldots \ldots \ldots \ldots \ldots \ldots \ldots$

Pumice, economic resource $\ldots \ldots \ldots \ldots \ldots \ldots$

Pupilla $\ldots \ldots \ldots \ldots \ldots \ldots \ldots \ldots \ldots \ldots \ldots \ldots \ldots \ldots$ muscorum $\ldots \ldots \ldots \ldots \ldots \ldots \ldots \ldots \ldots$

\section{$\mathbf{Q}, \mathbf{R}$}

Quaternary System $\ldots \ldots \ldots \ldots \ldots \ldots \ldots . \quad 56$

Radiocarbon age dating, acknowledgments.

Raft Formation $\ldots \ldots \ldots \ldots \ldots \ldots \ldots \ldots \ldots, 54,56,62$ measured sections $\ldots \ldots \ldots \ldots \ldots \ldots \ldots, 58,59,60$

Raft Lake Beds . . . . . . . . . . . . . . 56

Raft River valley, Starlight Formation .... 71

Rattlesnake Creek . . . . . . . . . . 16, 17, 43, 54 
References cited.

Retinella

Rock Creek $\ldots \ldots \ldots \ldots \ldots \ldots \ldots \ldots 34,46,47,70$

Rockland Valley, Starlight Formation .....

Rockland Valley fault

\section{S}

Sand and gravel, economic resources

Sand Hollow, pediment gravel

travertine

Salt Lake Formation . . . . . . . . . . . . .

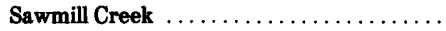

Schwagerina.

Sedimentary rocks, marine

Silicic rocks, composition

Silurian rock, Loktion ................

rocks, Laketown Dolomite.

Silurian System

Snake River

Aberdeen terrace deposits . . . . . . . . .

ancestral ......................

canyon, boulder bars .

composition of basalts . . . . . . . . . .

Cedar Butte Basalt. ...............

downcutting from flood

Raft Formation.

Snake River Plain, age of faults basalt flows $\ldots \ldots \ldots \ldots \ldots \ldots \ldots$ boundary $\ldots \ldots \ldots \ldots \ldots \ldots \ldots \ldots$ composition of basalts

origin

structure ...........

Tertiary and Quaternary deposits volcanism.

along south margin ........

Solenopleura

South Fork Pocatello Creek $\ldots$

Sphaerium sp. a .................. sp. b striatinum .

Springs, water temperature

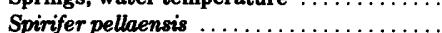

Squaw Creek ...............20, 22,

St. Charles Formation .................

upper member . ................

Worm Creek Quartzite Member

measured section ..................

Stagnicola albiconica ................ caperata.

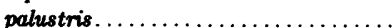

traskii.

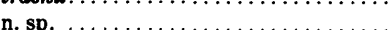

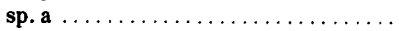

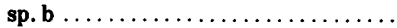

sp. $\ldots \ldots \ldots \ldots \ldots \ldots \ldots \ldots \ldots \ldots$

Starlight Creek. $\ldots \ldots \ldots \ldots \ldots \ldots \ldots \ldots 17,18,35$

Starlight Formation. ................

age and correlation $\ldots \ldots \ldots \ldots \ldots \ldots$

composition of basalts . . . . . . . . . .

fossils .......................

heavy minerals . . . . . . . . . . . . .

lower member.................

composition of silicic rocks .......

petrography .
Page

95,96

62

63

41, 43

35

7

83, 86

9
20

20
5

68

94, 95

69

81

65

95

58

92

94
5

82
91

85,91

42,45

61,67

Starlight Formation-Continued

middle member. . . . . . . . . . . .

petrographically unusual dike $\ldots \ldots \ldots$.

petrography $\ldots \ldots \ldots \ldots \ldots \ldots \ldots \ldots$ 70

source vents . . . . . . . .

structure $\ldots \ldots \ldots \ldots \ldots \ldots \ldots \ldots \ldots \ldots$

tuff of Arbon Valley . . . . . . . . . . . composition of silicic rocks ....... 86 petrography ............ 75

types of porphyritic basalt . . . . . .

upper member . . . . . . . . . . .

Sterling terrace deposits $\ldots \ldots \ldots \ldots \ldots \ldots$

Stratigraphic position, travertine . . . . .

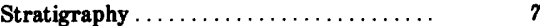

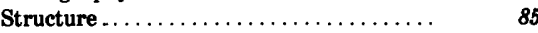

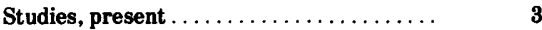

previous ...............

Sublett Range $\ldots \ldots \ldots \ldots \ldots \ldots \ldots \ldots, 5,29,30,81,71$ faults $\ldots \ldots \ldots \ldots \ldots \ldots \ldots \ldots \ldots \ldots$

geologic history of Triassic rocks .....

Pennsylvanian and Permian rocks ....

structure . . . . . . . . . . . . .

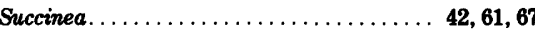

Sunbeam Creek $\ldots \ldots \ldots \ldots \ldots \ldots \ldots \ldots \ldots$ 18, 34, 35

Sunbeam Formation $\ldots \ldots \ldots \ldots \ldots \ldots \ldots$

equivalent gravel ............ 63

Swan Peak Quartzite . . . . . . . . . . . . $\quad \mathbf{9 , 1 8}$

Systems, Cambrian . . . . . . . . . . . 10

Devonian ..................

Mississippian ............... 22

Mississippian and Pennsylvanian ..... 27

Tertiary ..................

Ordovician $\ldots \ldots \ldots \ldots \ldots \ldots \ldots \ldots \ldots, \quad 17$

Pennsylvanian and Permian . . . . . . . 29

Quaternary ................

Silurian ................. 20

Tertiary or Quaternary . . . . . . . . .

$\mathrm{T}$

Table Mountain, basalt flows .......... 54

Little Creek Formation............ $\quad 51$

Massacre Volcanies ............. 54

Taylor, D. W., quoted on fossils ........ 41,45

Teewinot Formation ............. 43

Tertiary or Quaternary System......... 51

Tertiary rocks, displacement by faults..... 91

Tertiary System ................ ss

Thickness, Aberdeen terrace deposits ..... $\quad 68$

American Falls Lake Beds ......... 57, 66

Beirdneau Formation ............ 9, 22, 101

Big Hole Basalt . . . . . . . . . . . . . .

Bloomington Formation .......... 9, 13, 103

Camelback Mountain Quartzite ...... 9, 9,

Cedar Butte Basalt. . . . . . . . . . . . . 65

Deep Creek Formation . . . . . . . . 8, 24, 101

Elkhead Limestone $\ldots \ldots \ldots \ldots \ldots \ldots$, 9, 12, 104

Fish Haven Dolomite . . . . . . . . . . . 9, 19, 102

Garden City Formation . . . . . . . . . . 9, 17

Gibson Jack Formation . . . . . . . . 9,11, 12, 104

Great Blue Limestone $\ldots \ldots \ldots \ldots \ldots 8,26,25,100$

Hyrum Dolomite .............. 9, 20, 102

Laketown Dolomite ............. 9, 20, 102

Little Creek Formation .......... 51,52

4

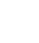

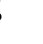

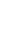


Thickness-Continued

Lodgepole Limestone . .

Page

lower member, Starlight Formation.

Manning Canyon Shale .

Neeley Formation

$8,28,29,99$

Nounan Dolomite . . . . . . . . . . . . 9, 15, 103

Oquirrh Formation . . . . . . . . 8, 29, 30, 98, 99

pediment gravel $\ldots \ldots \ldots \ldots \ldots \ldots \ldots$

61,62

Raft Formation ...................

56,58

St. Charles Formation . . . . . . . . 9, 15, 16, 102

Sunbeam Formation ...............

Swan Peak Quartzite

travertine

upper member, St. Charles Formation.

Walcott Tuff

9,18

62,63

16

Worm Creek Quartzite Member ......

Three Forks Formation.

Thrust faults

new interpretation in

Travertine.

Trilobites, Bloomington Formation

Triticites

Tuff at Ammon, composition of silicic rocks

Starlight Formation

composition of silicic rocks

Mollys Nipple

petrography

structure

Sunbeam Creek

46,50

15,102

2,22

88,89

Tuffs, middle member, Starlight Formation 36, 37, 38

Type locality, Manning Canyon Shale.....

Oquirrh Formation

Type section, Deep Creek Formation ..... .

\section{U, V}

Upper member, Starlight Formation ......

Starlight Formation, age .......... composition of silicic rocks
Ute Limestone $\ldots \ldots \ldots \ldots \ldots \ldots \ldots$

Page

Vallonia cyclophorella .............. $\quad 61,67$ gracilicosta .....................

n. sp. ..................... 42

Valvata humeralis. . . . . . . . . . . . 42, 45, 61, 67 utahensis . . . . . . . . . $61,6 \ldots \ldots \ldots$

Vegetation...................... 6

Vertigo gouldii ................... spp...................... 42

Vitrophyre $\ldots \ldots \ldots \ldots \ldots \ldots \ldots \ldots \ldots \ldots, \quad 40$

Volcanism, Snake River Plain .......... 94

Walcott Tuff $\ldots \ldots \ldots \ldots \ldots \ldots \ldots \ldots \ldots \ldots \quad 46,69$ composition of silicic rocks ......... $\quad 87$ measured section . . . . . . . . . . . . 49 petrography $\ldots \ldots \ldots \ldots \ldots \ldots \ldots \ldots, \quad \mathbf{7 5}$

Warm Creek, travertine in valley .........

Warner Flat . . . . . . . . travertine ................. 63

Warner Flat fault . . . . . . . . . . . . . .

Water Canyon. . . . . . . . . . measured section . . . . . . . $100 \ldots \ldots \ldots$

Water tables, perched . . . . . . . . . . . . . 96

Wedekindellina....................

Well Canyon $\ldots \ldots \ldots \ldots \ldots \ldots \ldots \ldots \ldots \quad 25,28$

West Fork Sunbeam Creek ...........

West Hills, thrust fault . . . . . . . . . . . . . . $\quad 89$

White Quartz Mountain . . . . . . . . . 18, 19, 21 structure .................... $\quad 88$

Willard thrust .................... 89

Woodruff Creek thrust fault. ............ 89

Worm Creek Quartzite Member, St. Charles Formation ......... 9,15

St. Charles Formation, measured section $\ldots \ldots \ldots \ldots \ldots \ldots \ldots, 102$

86 Zonitoides arboreus ............... 67 
